\title{
THE CZECHOSLOVAK ORIENT: CARPATHIAN RUTHENIA AS AN IMAGINED COLONIAL SPACE
}

\author{
BY \\ GEOFFREY BROWN
}

\begin{abstract}
A thesis
submitted to Victoria University of Wellington

in fulfilment of the requirements for the degree of

Doctor of Philosophy in History
\end{abstract}

Victoria University of Wellington

2016 
Figure 0.1 - "Let's Get To Know the People and Beauty of Subcarpathian Ruthenia!" Czech Tourist Guidebook Cover (1937)

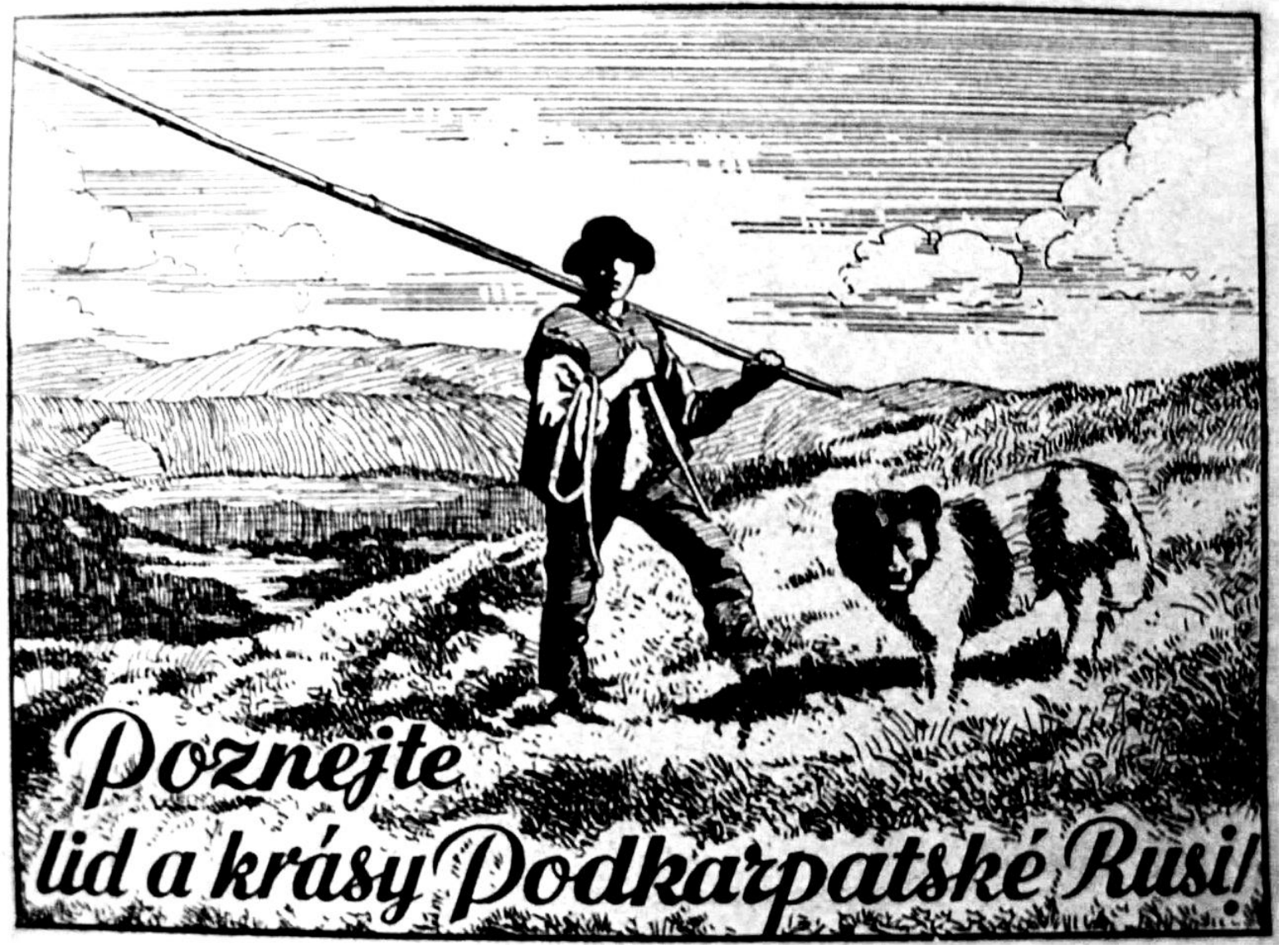

"Poznejte lid a krásy Podkarpatské Rusi!"

(Uzhhorod: Národohospodářský sbor pro zemi Podkarpatoruskou, 1937). 


\begin{abstract}
In 1919 the territory of Subcarpathian Ruthenia joined the new state of Czechoslovakia under the terms set by the Treaty of Saint Germain. During the following twenty years a relationship developed between Czechs and Ruthenia's Rusyn inhabitants which this study considers as an example of imperialism and colonialism. The Czech media applied a colonial framework in its portrayals of Ruthenia, encouraging the Czech public to see the poor and undeveloped territory as a colony ruled from Prague. Rusyns also used colonial terminology as a means of criticizing the Czech officials who ruled them. The colonial discourse occurred despite a shared Slavic ethnic background and even as representatives of both nations expressed brotherhood and solidarity towards one another. Some Czech officials sent to Ruthenia adopted imperialist attitudes and practices in an environment of minimal bureaucratic oversight, leading to friction with the Rusyn intelligentsia. Faced with the threat of Czechization, Rusyns struggled to achieve autonomy and an anti-imperialist movement supporting Rusyn rights developed among Czech Communists. The Prague government sought to defend its actions in Ruthenia against accusations of mistreatment by the Hungarian revisionist movement.
\end{abstract}

The existing Anglophone and Czech-language historiography on interwar Ruthenia generally portrays Czech rule as kindly and beneficial for the Rusyn population, focusing on Slavic kinship. Aiming to provide a fresh and detailed analysis of the Czechoslovak administration and the cultural forces at work in forming a colonial discourse, this study draws on an extensive range of government documents, newspapers and archival materials collected in Prague and Brno. By applying the theories of Edward Said, Jürgen Osterhammel, Maria Todorova and Kristin Kopp, the relationship is assessed through the terminology of discursive and material colonialism, together with Orientalism, liberal imperialism and internal colonialism. Three different areas of scholarly interest are the focus of this study: symbolic geography and colonial discourses in European contexts, political and social developments in Ruthenia, and treatment of national minorities in interwar Czechoslovakia.

The study includes eight chapters which alternate between viewing the relationship from the Czech perspective and the Rusyn perspective. The opening chapter analyzes the Czech role as Slavic leaders and benefactors in the new republic and how a Czech humanitarian mission 
became a mission civilisatrice. The second chapter focuses on the shift in thinking among Rusyns from jubilation after joining the republic to growing disillusionment over denial of political autonomy. Chapters three and four describe the formation of a discursive colonial relationship; the third chapter presents how Czechs imagined Rusyns in the mold of colonial stereotypes, while the fourth chapter analyzes how Czechs and Rusyns imagined their relationship through comparisons to other colonial regions such as Africa, the Orient and Siberia. Chapter five focuses on the experiences of Czech officials working in Ruthenia, highlighting the shift in Rusyn perceptions of these administrators from Slavic brothers to imperialists. The role played by Czech official and publisher František Svojše as a symbol of Czech chauvinism receives special attention in the analysis. The sixth chapter covers the Czech anti-colonial movement among Communists and left-wing authors such as Ivan Olbracht who condemned the imperialist character of the Czech administration in Ruthenia. Chapter seven outlines the Rusyn struggle for autonomy and resistance of Czechization until the achievement of an independent parliament in 1938. The final chapter describes the Czech fear of imperial loss, analyzing how Czech media and politicians defended Czechoslovak rule in Ruthenia against international criticism and the Hungarian revisionist movement. 


\section{Acknowledgements}

Many people have offered advice and assistance during the preparation of this project, first and foremost my supervisors Dr. Alexander Maxwell and Dr. Adrian Muckle, who read and commented on innumerable chapter drafts. Dr. Alexander Maxwell has been particularly generous in offering his time and knowledge whenever it was required. PhDr. Jiří Vykoukal of Charles University in Prague provided early encouragement for this topic while supervising my Master's thesis. Thanks also to Milena Běličová of the Czech National Museum Archives and Jakub Doležal of the Czech Presidential Office Archives who both went above and beyond the call of duty to make materials available to me. The staff of the Slavonic Library, National Library and T.G. Masaryk Institute Archive in Prague and the Moravian Library in Brno helped with countless queries and requests. A special thanks also to Martina Hyklová, Ján Jencík and Lubomír Rudohradský who provided a sounding board for ideas and kindly offered accommodation during the research process. Thank you also to Victoria University of Wellington for providing a $\mathrm{PhD}$ scholarship and research travel funding which made this project possible. 


\section{Table of Contents}

Abstract $\quad$ iii

Acknowledgements $\quad \mathrm{v}$

List of Figures $\quad$ vii

A Note on Terminology: Place Names, Spelling and Transliteration viii

$\begin{array}{ll}\text { Introduction } & 1\end{array}$

\section{Chapter 1}

Slavic Benefactors for a Poor Nation

Chapter 2

From Euphoria to Disillusionment: Rusyn Responses to Czech Rule

\section{Chapter 3}

Constructing a Czech Civilizing Mission:

Stereotyping Rusyns as a Primitive "Other"

Chapter 4

Colonial Fantasies: Ruthenia Imagined as African and Oriental

\section{Chapter 5}

From Humanitarianism to Imperialism:

Rusyn Views of František Svojše and Czech Officials in Ruthenia

\section{Chapter 6}

Ivan Olbracht and the Czech Anti-Imperialist Movement

\section{Chapter 7}

The Rusyn Struggle for Autonomy

\section{Chapter 8}

Defending Czech Rule: The International Campaign against Charges of Imperialism

\section{Conclusion}

Bibliography 


\section{List of Figures}

0.1 'Let's Get To Know the People and Beauty of Subcarpathian Ruthenia!" Czech Tourist Guidebook cover, 1937

0.2 Map “Czechoslovakia 1919-1938” 2

0.3 Map "Carpathian Ruthenia” $\quad 3$

2.1 “Carpatho-Rusyn Labour Party Campaign Poster,” Russkaia zemlia, $1925 \quad 63$

3.1 Cartoon "Rusyn with Pig," Podkarpatské hlasy, 1925

3.2 Cartoon “Election Speech,” Podkarpatské hlasy, 1925

3.3 Cartoon "On the Antalovtsi/Antalovec Railway line,"

Podkarpatské hlasy, 1925

4.1 Headline and Photographs from Polední list Article

"Subcarpathian Ruthenia - Our Future Colony," 1937

5.1 František Svojše Endorsing an Uzhhorod Suitcase Retailer,

Podkarpatské hlasy, 1926

5.2 "The Idea of Slavic Reciprocity in Practice in Ruthenia,"

Podkarpatské hlasy, 1926

6.1 Cover of Vašek Káňa’s Book Transcarpathia (1932)

8.1 Cartoon "We Are a Peace-Loving Nation," Humoristecké listy, 1927 


\section{A Note on Terminology: Place Names, Spelling and Transliteration}

The territory known today as Zakarpattia oblast in Ukraine has amassed an astonishing number of names throughout its history. In English the territory has been referred to in different time periods as "Ruthenia," "Subcarpathian Ruthenia," "Subcarpathia," "Subcarpathian Rus'," "Transcarpathia," "Transcarpathian Ruthenia," "Transcarpathian Ukraine," "Carpathian Rus'," and "Carpatho-Ukraine." All names carry historical and political baggage, and therefore no single name has come to form a universally accepted standard. In Czech the territory has generally been referred to as "Podkarpatská Rus" [Subcarpathian Rus'/Ruthenia] since the 1920s, though alternate historical names have included "Uherská Rus," "Karpatská Rus," "Země Podkarpatoruská," "Rusinsko," "Zakarpatsko," and "Podkarpatsko." During the interwar period Rusyns referred to their territory as "Karpatska Rus" or "Podkarpatska Rus" and in 1938-1939 also as "Karpats'ka Ukraina."

Choosing the appropriate toponym for the territory thus presents many problems for scholars of East-Central Europe. Numerous names have appeared in English scholarship, including Transcarpathian Ukraine and Carpathian Rus'. However, the use of "Rus" and "Ukraine" in these names may suggest preference for Russian or Ukrainian particularist views of the territory's national loyalty. Even the geographical terms "Subcarpathian" and "Transcarpathian" are subject to political interpretation, as they imply viewpoints from opposing sides of the Carpathian Mountains. Subcarpathian ("Podkarpatská" in Czech) describes the territory as if viewed from the Bohemian Lands to the west, placing it below or beneath the Carpathian mountains. Meanwhile Transcarpathia ("Zakarpattia" in Ukrainian) views the territory from Kyiv and the Ukrainian steppe to the east, placing it behind or beyond the mountain range. All options are politically sensitive, but this study will use the term "Carpathian Ruthenia," shortened in most instances to "Ruthenia," instead of the adjectives "Subcarpathian" and "Transcarpathian" and nouns "Rus" and "Ukraine" in an effort to limit connotations. The author is aware that some scholars may disagree with this usage, particularly as the term Ruthenia can also be applied to a much larger historical territory. However, non-Carpathian Ruthenia as a region has no particular role in this study, and shortening Carpathian Ruthenia to 
Ruthenia will save significant space in the text. Czechoslovak Ruthenia will also be used in some instances to help specify the time period from 1919-1939 in the territory.

The national ethnonym to describe the Slavic inhabitants of Ruthenia is also problematic, particularly the appropriate adjective, which in English is usually given as "Rusyn" or "Ruthenian." The adjective "Ruthenian" can apply to the Slavic inhabitants of Ruthenia, but also to the inhabitants of Ruthenia regardless of their nationality. Use of "Ruthenian" also invites confusion as it overlaps with historical usage of the word for Slavs living in the north-east of the Austro-Hungarian Empire, including the regions of Galicia and Bukovina. This study will use "Rusyns" and the adjective "Rusyn," though the author anticipates that some scholars may think differently as there is no common consensus. Translations of the adjectives rusky and русскій are similarly problematic; they can be translated as "Rusyn" or "Russian" depending on context. For reasons of consistency this study will translate these words as "Rusyn" unless the historical author is clearly making a statement showing Russophile preference.

Determining which name to use for cities, towns and other geographical features in EastCentral Europe is another contentious issue. Official place names in the region have sometimes changed multiple times during the past century and can have four or more names from different time periods. Readers who are unfamiliar with the region cannot be expected to know that Ужгород, Uzhhorod, Uzhgorod, Užhorod, Ungvár and Ungwar all refer to the same city, today the capital of Zakarpattia oblast in Ukraine. Scholars have tried to get around this concern by providing all the appropriate linguistic variations of a name (such as L'viv/Lwów/Lvov/Lemberg) at least the first time the city is mentioned in a text, though this approach also invites controversy based on which language's name is listed first, second, third, etc. Additional questions arise over which and how many linguistic variants should be provided and with what justification. Authors such as Jeremy King and Pieter Judson have extended this approach and given two or more names for cities consistently throughout an entire text (Budweis/Budějovice), and King has also applied this method to the names of historical individuals with ambiguous national loyalties (Vinzenz Paschek/Čeněk Pašek). ${ }^{1}$

\footnotetext{
${ }^{1}$ Jeremy King, Budweisers into Czechs and Germans (Princeton: Princeton University Press, 2002); Pieter Judson, Guardians of the Nation: Activists on the Language Frontiers of Imperial Austria (London: Harvard University Press, 2006).
} 
Aware that all methods are open to criticism and dispute, this study will give place names according to the official form of the country in which they are currently located, followed by the historical name from the time period under discussion if it is different (Uzhhorod/Ungvár). In some instances where additional names hold relevance to the study they have been included as well (Sighetu Marmației/Máramarossziget/Marmaroš Sihot). This system will apply the first time a place name is mentioned, while subsequent inclusions will give only the present-day name for reasons of brevity. Use of present-day names also permits readers to consult modern atlases. Where there is a commonly accepted spelling of a city name in English this has been applied, such as Prague, Vienna and Warsaw, and this convention also extends to regional names such as Bohemia, Moravia and Galicia. Place names in Ruthenia have been transliterated according to the Library of Congress format for Ukrainian using their present-day names, with the Czechlanguage name used during the interwar period (Mizhhiria/Volové) provided when the place is first mentioned.

Transliterations of publication titles provided in footnotes follow the Library of Congress format for Ukrainian and Russian, with additional modifications for Rusyn based on the guidelines provided by Elaine Rusinko in her book Straddling Borders: Literature and Identity in Subcarpathian Rus'.2 Texts which include both "i" and " transliterated as Rusyn, distinct from either Russian or Ukrainian, according to Rusinko's guidelines. Soft and hard signs are included, except for hard signs which come at the end of words, following Rusinko's method. Spellings and transliterations for the names of historical actors in Ruthenia also follow the standard set by Rusinko and Paul Robert Magocsi and Ivan Pop in their edited volume The Encyclopedia of Rusyn History and Culture. ${ }^{3}$ All translations and transliterations are those of the author, unless specifically stated otherwise in the text.

\footnotetext{
${ }^{2}$ Elaine Rusinko, Straddling Borders: Literature and Identity in Subcarpathian Rus' (Toronto: University of Toronto, 2003), xiii.

${ }^{3}$ Paul Robert Magocsi and Ivan Pop, The Encyclopedia of Rusyn History and Culture (Toronto: University of Toronto Press, 2002).
} 


\begin{abstract}
Abbreviations
AKPR - Archiv Kanceláře prezidenta republiky [Czech Presidential Office Archives]

PR - Fond Podkarpatská Rus [Collection Subcarpathian Ruthenia]
\end{abstract}

ANM - Archiv Národního muzea [Czech National Museum Archives]

Fond Starý [Dr. Starý Collection]

Fond Brandejs [Jan Brandejs Collection]

AÚ TGM - Archiv Ústavu T.G. Masaryka [T.G. Masaryk Institute Archives]

TGM-R - Fond T.G. Masaryk - Republika, Podkarpatská Rus

[Collection T.G. Masaryk - Republic, Subcarpathian Ruthenia] 


\section{Introduction}

In 1923, a Rusyn inhabitant of Velykyi Bychkiv/Velký Bochkov, a small town in Czechoslovak Ruthenia, wrote to a local newspaper to express his frustration with the Czech officials who had come to run the regional administration. He lamented their habit of lining their own pockets and the disrespect they held for the local inhabitants, casting Rusyns as victims of Czechs who had come to colonize them:

We demand an end to this African Order by which they rule over us, those who were sent to us from Prague to help us and not to drink our blood [...] We ask that these scoundrels be sent back to Prague, and if there is no place for them there, send them to Africa where they can make fortunes for themselves instead of here among us Rusyns. ${ }^{1}$

The author's words not only encompass the loss of Rusyn trust in Czech leadership which occurred within just a few years of joining the Czechoslovak Republic in 1919; by casting Czech officials as African colonizers exploiting the local population, they reflect a broader colonial discourse which had taken root in Czech-Rusyn relations.

This study assesses the Czech-Rusyn relationship in interwar Czechoslovakia in terms of imperialism and colonialism, placing it within the context of European imperialist practices conducted in the early twentieth century. The Czech media and popular culture placed a colonial framework onto Ruthenia in its portrayals of the region, thereby encouraging the Czech public to think of Ruthenia as if it were in essence a colony ruled from Prague. In the Czech imagination, Ruthenia and its predominantly Greek Catholic and Orthodox Slavic inhabitants, the Rusyns, took on the characteristics of an overseas colony which led to comparisons to Africa, the Orient and Asia. Rusyn intellectuals also adopted an anti-colonial consciousness, using colonial terminology as a means of criticizing the Czech officials who lived among them. Features of the Czechoslovak government's system of administration in Ruthenia can also be assessed in terms of imperialism, since the Czech-dominated administration ruled against the wishes and constitutional rights of the Rusyn people. This study contributes to the growing field of colonialism set in a European context, alongside the work of Kristin Kopp, Larry Wolff, Susanne

\footnotetext{
1 “Afrykansky poriadky,” Karpato-Russkii vîstnyk (21 January 1923), 10-11.
} 
Zantop and others. Additionally, by drawing on both Rusyn and Czech materials this study considers the extent of Rusyn resistance to Czech rule, thus contributing to a greater understanding of the Rusyn political struggle to achieve autonomy.

Figure 0.2 - "Czechoslovakia 1919-1938"2

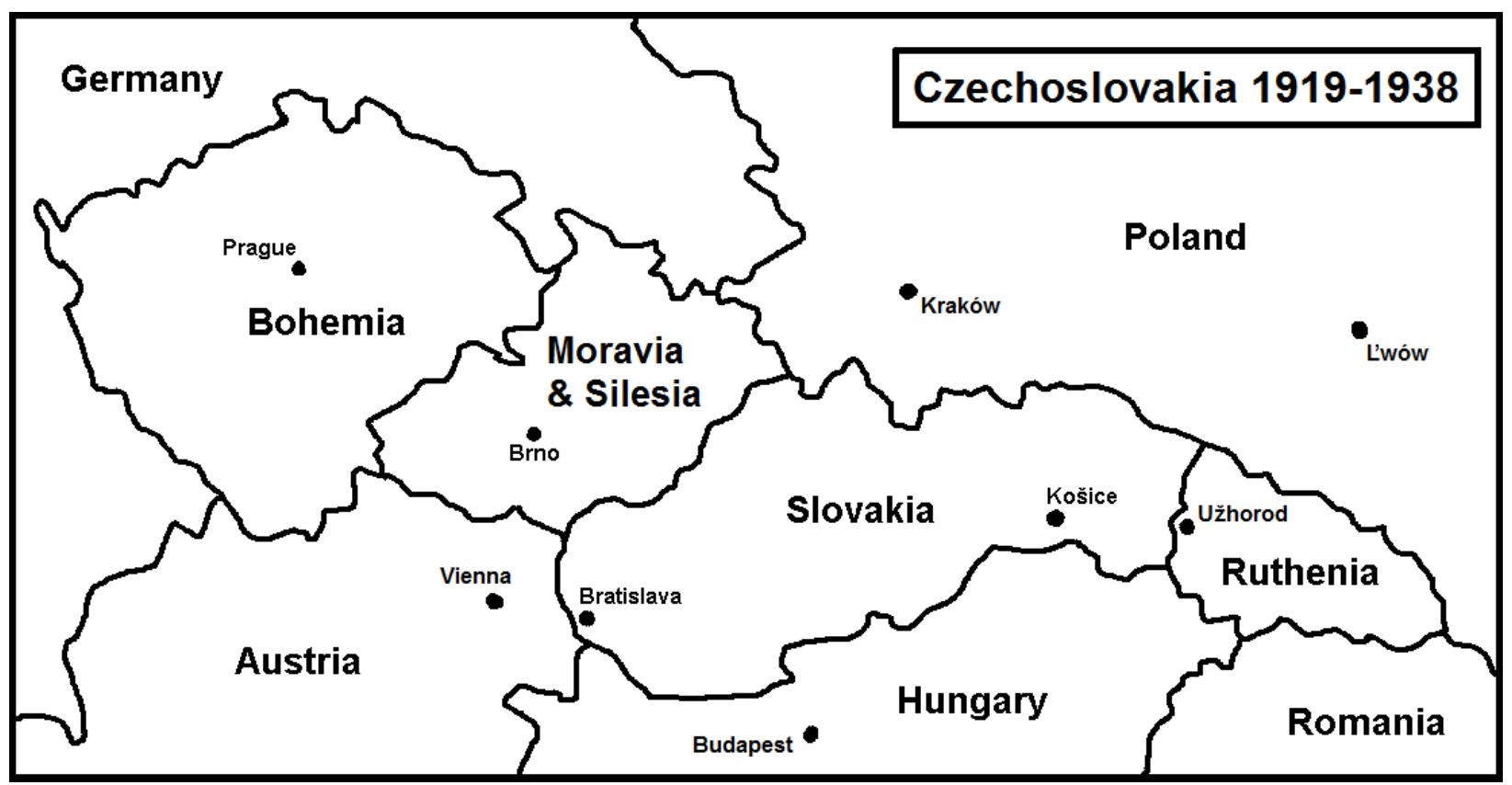

A colonial discourse developed in the dialogue between Czechs and Rusyns in Czechoslovakia despite their shared Slavic ethnic background and the previous experience of Czechs as an oppressed nation in the Austro-Hungarian Empire. Both Czech and Rusyn intellectuals participated in constructing this discourse throughout the twenty years of the First Republic even as they continued to express brotherhood and solidarity towards one another. Czech views of Rusyns contained two distinct and opposing images, with Ruthenia seen simultaneously as a brotherly Slavic region and as a barbarous Oriental territory which required civilizing. Conflicting images of the "good Slavic Rusyn" and the "savage Rusyn" appeared throughout the interwar period. In turn, the Rusyn view included overlapping images of Czechs as both friendly Slavic kin and unwelcome imperialist occupiers. This mentality extended to the policy level in administration; despite the Prague government's continued assertions of noble

\footnotetext{
2 “Czechoslovakia 1919-1938," map drawn by the author.
} 
intentions and Slavic solidarity towards Rusyns, some Czech officials sent to Ruthenia adopted colonial attitudes and practices in an environment of minimal bureaucratic oversight.

Figure 0.3 - "Carpathian Ruthenia"3

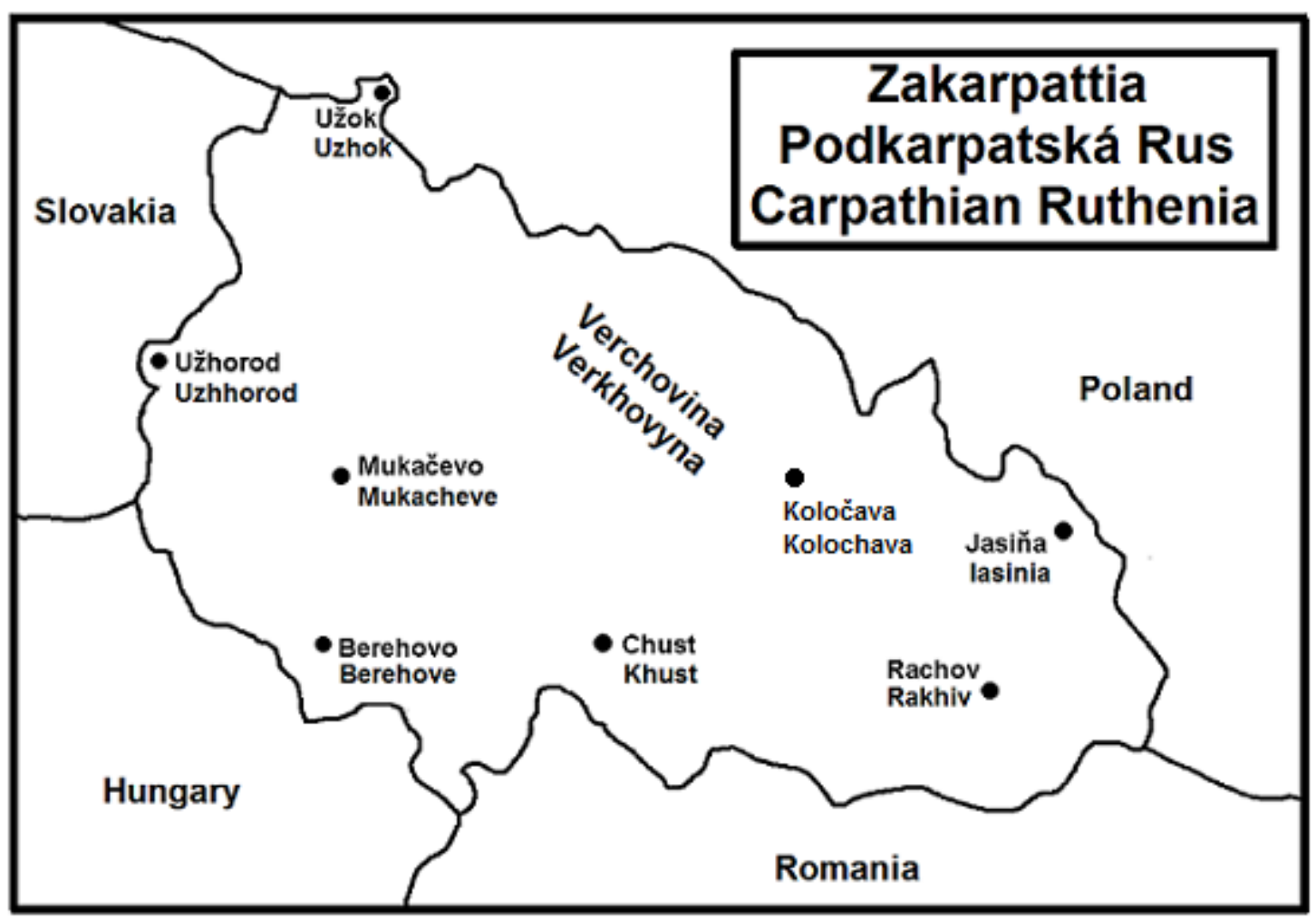

Twentieth-century scholarship on interwar Czechoslovakia, as distinct from scholarship specifically devoted to Ruthenia, largely focused on retelling the inspirational story of President Tomáš Garrigue Masaryk and Foreign Minister Edvard Beneš who built a thriving democracy as neighbouring states fell victim to authoritarianism. While inspirational narratives dominate Czech scholarship, Anglophone scholarship, often written by Czech expatriates in the USA and UK, followed a similar line depicting the unblemished character of the good Czech nation. Poking holes in this overly-simplistic narrative of Czech leadership is a twenty-first-century phenomenon; Andrea Orzoff's Battle for the Castle: The Myth of Czechoslovakia in Europe 1914-1948 and Mary Heimann's Czechoslovakia: The State that Failed deconstructed the legends surrounding relations between Czechs and other national groups in the republic and demonstrated that Czech (and Slovak) nationalists had been "no more immune from the

\footnotetext{
3 “Carpathian Ruthenia," map drawn by the author.
} 
temptations of authoritarianism, bigotry and cruelty than anyone else."4 Heimann declares it is "time to abandon the Whig interpretation of Czechoslovak history," and her willingness to question the clear conscience of the Czech elite in its dealings with Czechoslovakia's minorities provided inspiration for the aims of this study. ${ }^{5}$

The existing Anglophone historiography on interwar Ruthenia generally portrays Czechoslovak rule as helpful and beneficial for the Rusyn population. Judy Batt has referred to it as a "golden age" for Rusyn cultural and economic development, ${ }^{6}$ while Elaine Rusinko has called the Czechoslovak period a "true renaissance" for Ruthenia following on the heels of Hungarian rule. ${ }^{7}$ Such claims reflect the interest of these scholars in focusing primarily on Rusyn cultural and literary achievements, but the Rusyn cultural awakening in Czechoslovakia presents only one aspect of a relationship which at the time many Rusyn intellectuals, as well as Czechs, labelled as imperialist and hostile to Rusyn interests. Twentieth-century scholars of Czech heritage focused on the relative advantages inclusion in Czechoslovakia had for Ruthenia compared with neighbouring Poland, Hungary, or Romania. ${ }^{8}$

Although Rusinko has called Czech rule beneficial for Rusyns, she has also alluded to concepts of "Czech colonialism" and "cultural imperialism" in the context of Rusyn interwar literature. She considers Czechization a form of motivation which led Rusyns to develop their own "postcolonial literature." Her assessment of cultural imperialism in Czechoslovakia forms part of a broader narrative of the Rusyn struggle to achieve a distinct culture and language in spite of suppression by the larger nations which have ruled them. She has also identified nineteenth-century examples of Rusyn authors who drew comparisons between their situation under Hungarian governance and colonized peoples in India and Ireland under British rule. ${ }^{10}$

\footnotetext{
${ }^{4}$ Mary Heimann, Czechoslovakia: The State that Failed (London: Yale University Press, 2009), xxi.; Andrea Orzoff, Battle for the Castle: The Myth of Czechoslovakia in Europe, 1914-1948 (Oxford: Oxford University Press, 2009).

${ }^{5}$ Heimann, Czechoslovakia: The State that Failed, 324.

${ }^{6}$ Judy Batt, "Transcarpathia: The Centre of Europe" in Region, State and Identity in Central and Eastern Europe, Judy Batt, Kataryna Wolczuk, eds. (London: Routledge, 2013), 166.

${ }^{7}$ Rusinko, Straddling Borders: Literature and Identity in Subcarpathian Rus', 296.

${ }^{8}$ František Nemec and Vladimir Moudry, The Soviet Seizure of Subcarpathian Ruthenia (Toronto: William Anderson, 1955), 41. See also Viktor Mamatey and Radomír Luža, eds., A History of the Czechoslovak Republic 1918-1948 (Princeton: Princeton University Press, 1973).

${ }^{9}$ Rusinko, Straddling Borders: Literature and Identity in Subcarpathian Rus', 17.

${ }^{10}$ Rusinko, Straddling Borders: Literature and Identity in Subcarpathian Rus', 16.
} 
Paul Robert Magocsi occupies a unique place in English-speaking scholarship on Ruthenia, having studied the history of the Rusyn nation for the past four decades. ${ }^{11}$ His analysis of the Czech-Rusyn relationship in Czechoslovakia has focused primarily on Rusyn actors while highlighting Czechoslovakia's role in the development of Rusyn nationalism. In doing so he has focused on the enormous social, economic and cultural progress made by Rusyns during Czech rule in contrast to the Hungarian and Soviet eras which bookended it. ${ }^{12}$ Magocsi has explored the tensions between Rusyn intellectuals and the Prague government over the questions of autonomy, language rights and placement of territorial borders, concluding that Czech intentions were largely well-meant despite the friction, and that Czechoslovak democracy had "a very positive effect" in Ruthenia's development. ${ }^{13}$ While this study will not dispute the progress in Rusyn culture during the period, it argues that viewing Czechoslovak Ruthenia through a colonial lens can help to question the motivations of the Czech administration and bring new insight to Rusyn perceptions of Czech rule. Additionally, no detailed study of the Czechoslovak administration in interwar Ruthenia has appeared in the work of Magocsi or other Anglophone scholars, and this study aims to begin filling this gap in scholarship.

Ruthenia as a part of interwar Czechoslovakia has received significant coverage in Czech-language scholarship, with Czech rule usually cast in a heroic narrative of Slavic brotherhood. Jaromír Hořec's 1994 book Podkarpatská Rus - země neznámá [Subcarpathian Ruthenia - Terra Incognita] depicts Czechoslovakia as a caregiver which improved Rusyn cultural and living standards; Hořec reminds Rusyns that when they hear the Czech and Slovak anthems, they should remember Czechoslovakia's "help in their journey towards democracy and freedom." ${ }^{14}$ Ivan Pop, born in Czechoslovak Ruthenia and a significant scholar of Rusyn studies in the Slavic world, sees the period of Czech administration for the territory as an important process of education for Rusyns, concluding that they would not have fared better within the

\footnotetext{
${ }^{11}$ Selected titles from the large publication record on Ruthenia by Paul Robert Magocsi: The Shaping of a National Identity: Subcarpathian Rus', 1848-1948 (Cambridge: Harvard University Press, 1978); A History of Ukraine: The Land and Its Peoples (Toronto: University of Toronto Press, 2010); Magocsi and Pop, Encyclopedia of Rusyn History and Culture; With Their Backs to the Mountains: A History of Carpathian Rus' and Carpatho-Rusyns (Budapest: Central European University Press, 2015).

${ }^{12}$ Magocsi, The Shaping of a National Identity, 191.

${ }^{13}$ Magocsi, A History of Ukraine, 646. Magocsi describes Czech-Rusyn relations in greater detail in The Shaping of a National Identity, 191-246.

${ }^{14}$ Jaromír Hořec, Podkarpatská Rus - země neznámá (Jinočany: H\&H, 1994), 7.
} 
borders of another state. ${ }^{15}$ David Svoboda and Viktor Budín have described Ruthenia's appeal as an exotic unknown in the Czech imagination, while presenting Czech accomplishments in the region. ${ }^{16} \mathrm{~A}$ few Czech authors have been more critical when looking at the Czech-Rusyn relationship; Jan Rychlík and Magdaléna Rychlíková's 2013 study of Czechoslovak involvement in Ruthenia concludes that not all government policies were beneficial for the Rusyn people. They acknowledge that Czech officials made mistakes in their administration of the territory and that there were frequent disagreements with the local Rusyn population. ${ }^{17}$ However, the general trend in Czech scholarship has focused on the positive results of the relationship, with Czechs considered righteous helpers and educators in a poor Slavic territory. Popular histories of Czechoslovak Ruthenia such as Petr Štěpánek's Podkarpatská Rus v letech 1919-1939 [Subcarpathian Ruthenia in the Years 1919-1939] provide nostalgia tinged with national pride, while encouraging Czech tourism in the region. ${ }^{18}$

A Czech-authored book chapter describing Czech views of 1920s Ruthenia as Orientalist appeared in tandem with the writing of this study; Stanislav Holubec uses Czech-language books and newspapers to depict Czech visions of their superiority over Ruthenia's Rusyns, Hungarians and Jews. ${ }^{19} \mathrm{He}$ analyzes the depiction of Ruthenian "enemies" (Communists, Ukrainian immigrants, the Magyarone Greek Catholic clergy) in Czech sources as evidence of attempts to justify the need for Czech rule. While further developing some of these themes, this study considers both Czech and Rusyn perspectives on Ruthenia based on archival sources, while drawing upon theoretical approaches to the study of colonialism and imperialism.

Authors from other central and east European states have been more willing to critically examine Czech rule, while often reflecting their own national perspectives. Slovak scholar Peter Švorc has published numerous books and articles about political developments in Ruthenia during the interwar period, most significantly Zakletá zem [Cursed/Enchanted Land] which casts

\footnotetext{
${ }^{15}$ Ivan Pop, Podkarpatská Rus (Prague: Libri, 2005), 129.

${ }^{16}$ David Svoboda, “Češi v zemi beze jména," in Lidé města revue (March 2005, Volume 17), 117; Viktor Budín, Podkarpatská Rus očima Čechů (Prague: Společnost přátel Podkarpatské Rusi a Rusinká sekce, 1996), 18.

${ }^{17}$ Jan Rychlík and Magdaléna Rychlíková, Hospodářský, sociální, kulturní a politický vývoj Podkarpatské Rusi 1919-1939 (Prague: Národohospodářský ústav, 2013), 121-124.

${ }^{18}$ Petr Štěpanek, Podkarpatská Rus v letech 1919-1939 (Náchod: Konting, 2008).

${ }^{19}$ Stanislav Holubec, "Czech Perceptions of Sub-Carpathian Rus and its Modernization in the 1920s," in Mastery and Lost Illusions: Space and Time in the Modernization of Eastern and Central Europe, Włodzimierz Borodziej, Stanislav Holubec and Joachim von Puttkamer, eds. (Munich: Oldenbourg, 2014), 223-250.
} 
a critical eye on the Prague government's reluctance to grant autonomy for Rusyns. ${ }^{20}$ Rusyn Ukrainophile authors such as Vasyl Hrendzha-Dons'kyi have recounted their roles in achieving an autonomous Carpathian-Ukraine in 1938 despite Czech resistance. ${ }^{21}$ Among notable presentday Ukrainian scholars, Mykola Vehesh, a resident of Uzhhorod, has written on the life of Rusyn Ukrainophile leader Avhustyn Voloshyn and his significance for the Ukrainian nation. ${ }^{22}$ Hungarian and Rusyn Magyarophile authors have long been dismissive of interwar Czechoslovakia's control of Ruthenia; politician Károly Hokky and academic Sándor Bonkáló produced works based on their personal experience of interwar Ruthenia which brought criticism of Czechoslovakia's rule to an English-speaking audience. ${ }^{23}$ More recently, a 2009 study of twentieth-century Ruthenia edited by Csilla Fedinec and Mykola Vehesh criticized aspects of Czechoslovak control of the territory and the denial of Rusyn autonomy. ${ }^{24}$ Meanwhile, Russian author Andrei Pushkash has criticized the Czech and Hungarian periods in Ruthenia while focusing on the industrialization and improvements in education brought by Soviet leadership. ${ }^{25}$

Although Czechoslovak Ruthenia has received significant scholarly attention, colonial and imperial theory has yet to play a major role in the analysis of Czech-Rusyn relations in any language. Therefore this study seeks to bring a new analysis of the relationship between Czechs and Rusyns by placing it within the context of colonial power structures prevalent in interwar Europe. Determining to what extent Czechoslovak Ruthenia can be considered an example of a colonial power structure will permit a reassessment of the predominant view of a benevolent Czechoslovak administration for Ruthenia built on Slavic brotherhood.

Drawing on colonial and imperial theory in a study of Czechoslovak Ruthenia is certainly not without controversy. Conventional definitions still consider colonialism to be a phenomenon which occurs outside of Europe, and scholars have questioned the relevance of applying colonial analysis to European case studies. Prominent postcolonial scholar Gayatri Chakravorty Spivak

\footnotetext{
${ }^{20}$ Peter Švorc, Zakletá zem: Podkarpatská Rus 1918 - 1946 (Prague: NLN, 2007). See also: Peter Švorc, “Začlenenie Podkarpatskej Rusi do ČSR (1918-1920)," in Česko-slovenská historická ročenka 1997 (Brno: Masarykova univerzita, 1997), 39-60.

${ }^{21}$ Vasyl Hrendzha-Dons'kyi, Shchastia i hore Karpatskoi Ukrainy (Uzhhorod: Zakarpattia, 2002).

${ }^{22}$ Mykola Vehesh, Avhustyn Voloshyn i Karpats'ka Ukraïna (Lviv, ZUKTs, 2004).

${ }^{23}$ Sándor Bonkáló, The Rusyns (New York: Columbia University Press, 1990); Károly Hokky, Ruthenia: Spearhead towards the West (Trenton, Florida: Danubian Research Centre, 1966).

${ }^{24}$ Csilla Fedinec and Mikola Vehes, eds., Kárpátalja 1919-2009, Történelem, politika, kultúra (Budapest: MTA Etnikai-nemzeti kisebbségkutató intézete, 2009).

${ }^{25}$ Andrei Pushkash, Tsivilizatsiia ili varvarstvo, Zakarpate 1918-1945 (Moscow: Evropa, 2006).
} 
suggests that the terms "colonizer" and "colonized" are flexible enough to apply to examples in historical central and Eastern Europe provided that they pertain to circumstances "when an alien nation-state establishes itself as ruler, impressing its own laws and systems of education, and rearranging the mode of production for its own economic benefit." ${ }^{26}$ However, Frederick Cooper has criticized the "bandwagon effect" of colonial studies, claiming that "looking for a "textual colonization' or a 'metaphoric colonization' distinct from the institutions through which colonial power is exercised risks making colonialism appear everywhere - and hence nowhere." 27 In response to Cooper's assertion, historian Kristin Kopp has argued that traditional studies of colonialism place too much significance on the study of "institutions and institutional policies" when seeking to identify colonialism, while "excluding" discourse, ideology and culture. She stresses the significance of analyzing cultural and social practices alongside government policies when seeking to label colonial situations, suggesting that European examples can be equally relevant. $^{28}$

This study draws upon terminology developed by Jürgen Osterhammel and Kristin Kopp to analyze the intentions and actions of the Prague government and Czech officials separately from the underlying cultural and psychological forces at work in forming a colonial discourse in Ruthenia. In order to distinguish these as separate concepts, both the organization of imperial rule and the psychology of a colonial fantasy, we can draw upon Osterhammel's observation that modern colonialism "is not only a relationship that can be described in structural terms, but also a particular interpretation of this relationship." 29 Osterhammel's approach has inspired Kristin Kopp to apply analyses of colonial discourses to case studies within Europe, focusing specifically on German construction of Poland as a colonial space in the nineteenth and early twentieth centuries. She describes the process of developing a colonial discourse in the imagination of colonizers and colonized as "discursive colonization," while the physical actions

\footnotetext{
${ }^{26}$ Gayatri Chakravorty Spivak, comments made in the roundtable discussion "Empire, Union, Center, Satellite: The Place of Post-colonial Theory in Slavic/Central and East European /(post-)Soviet studies: A Questionnaire," Ulbandus Review (2003, vol. 7), 15.

${ }^{27}$ Frederick Cooper, Colonialism in Question: Theory, Knowledge, History (Berkeley: University of California Press, 2005), 47.

${ }^{28}$ Kristin Kopp, "Gray Zones: On the Inclusion of 'Poland' in the study of German Colonialism," in German Colonialism and National Identity, Michael Perraudin and Jurgen Zimmerer, eds. (New York: Routledge, 2010), 3435 .

${ }^{29}$ Jürgen Osterhammel, Colonialism: A Theoretical Overview (Princeton: Markus Wiener, 2005), 16. Italics included in original.
} 
of administration and imperialist policies constitute "material colonization." For Kopp, this interpretation, in the form of discursive colonization, has three components: "the creation of a colonial subjectivity for the (would be) colonizer-self, [...] the construction of the Other as a legitimate object of colonial intervention, and a narration of the relationship between self and Other in colonial terms." ${ }^{30}$ Chris Bayly has also highlighted the importance of studying the role played by both colonizers and the colonized in the shaping of a "colonial narrative.",31

Kopp is aware that European case studies may not always include examples of material colonization in forms similar to those seen in overseas colonies. However, she stresses that material colonization could not occur without discursive colonization to give it a psychological reality, and that discursive colonization, the imagining of a colonial space, could apply equally to European examples as non-European ones. She compares discursive colonialism to Edward Said's analysis of Orientalism, since both describe "processes of constructing and delegitimizing the Other in discourse located at the nexus of knowledge and power." While Said considers Orientalism to be an existing social "institution" which inescapably permeates all Western engagement with the Orient, Kopp sees discursive colonization as part of a "process of becoming" when placed in a European context, a time when colonial paradigms are still developing and have yet to become institutionalized. ${ }^{32}$ Kopp's terminology of material and discursive colonization provides a useful reference point for approaching the Czech-Rusyn relationship as a European case.

Drawing upon Kopp's distinction between discursive and material colonization, Roisin Healy and Enrico Dal Lago have argued that within Europe, "discursive colonization did not develop into full material colonization, and even if only partly realized, colonial rhetoric had a major impact on the culture of European states."33 Their 2014 edited volume looks at several examples of discursive colonization in a European context, including Irish-English relations, northern Italian views of southern Italy, Habsburg rule of Bosnia-Herzegovina and interwar

\footnotetext{
${ }^{30}$ Kristin Kopp, Germany's Wild East: Constructing Poland as Colonial Space (Ann Arbor: University of Michigan Press, 2012), 6.

${ }^{31}$ Chris Bayly, Empire and Information: Intelligence Gathering and Social Communication in India 1780-1870 (New York: Cambridge University Press, 1996), 6. See also Bayly’s Imperial Meridian: The British Empire and the World, 1780-1830 (London: Longman, 1985).

${ }^{32}$ Kopp, Germany's Wild East, 9.

${ }^{33}$ Róisín Healy and Enrico Dal Lago, Introduction to The Shadow of Colonialism on Europe's Recent Past, Róisín Healy and Enrico Dal Lago, eds. (London: Palgrave Macmillan, 2014), 9.
} 
Poland's treatment of its eastern borderlands. ${ }^{34}$ From among these, Christoph Mick's identification of a colonial discourse in Poland's interaction with its ethnic Ukrainian regions is perhaps the most closely related to this study. Mick highlights Polish use of colonial stereotypes towards Ukrainians as evidence of a discourse, though he suggests that Poland's material actions towards its Ukrainian population were more of a nationalising movement than a colonial one, with the intention of turning "Ukrainian peasants into Poles or at least into loyal Polish citizens." He concludes that although administrative forms of material colonialism occurred only in part, a colonial discourse existed which cast Ukrainians as an uncivilized Other in Polish culture. ${ }^{35}$ In the case of Ruthenia, outright national assimilation may never have featured openly in the Prague government's policies, but some Rusyn intellectuals perceived the Czechization of their schools and administration as a covert attempt to make them into Czechs.

The work of Susanne Zantop on the "colonial fantasies" of pre-colonial Germany also offers useful terminology for approaching discursive colonial practices in Ruthenia. Zantop suggests that "colonial fantasies provide access to the 'political unconscious' of a nation, the desires, the dreams, and myths that inform public discourse," an approach which is incorporated in the analysis of the Czech imperial fantasy in chapter four of this study. ${ }^{36}$ Zantop feels it is also "necessary to explore the complexities of the nation's imagination in order to understand the lure of the 'colonial adventure,' particularly for those who, like the Germans, had been excluded from it." ${ }^{37}$ Interwar Czechs took a similar interest in the "colonial adventure" as a European nation without colonies, and many interwar publications detailed the journeys of Czech adventurers in Africa and the Orient. ${ }^{38} \mathrm{~A}$ movement to promote Czech claims on the former German territory of African Togoland proved unsuccessful in 1919, but reflected a deeper national interest in the exploits of other European colonial powers. ${ }^{39}$ Sarah Lemmen has described such Czech interest in Africa and the Orient in the early twentieth century as

\footnotetext{
${ }^{34}$ Healy and Dal Lago, The Shadow of Colonialism on Europe's Recent Past.

${ }^{35}$ Christoph Mick, "Colonialism in the Polish Eastern Borderlands 1919-1939," The Shadow of Colonialism on Europe's Recent Past, Róisín Healy and Enrico Dal Lago, eds. (London: Palgrave Macmillan, 2014), 139.

${ }^{36}$ Susanne Zantop, Colonial Fantasies: Conquest, Family and Nation in Precolonial Germany, $1770-1870$ (London: Duke University Press, 1997), 4.

${ }^{37}$ Zantop, Colonial Fantasies: Conquest, Family and Nation in Precolonial Germany, 1770 - $1870,4$.

${ }^{38}$ Czech publications on journies in overseas colonial territories are provided in chapter 4.

39 Jan Havlasa, České kolonie zámořské (Prague: Alois Wiesner, 1919).
} 
"noncolonial Orientalism" to differentiate it from the colonial interests of European powers with overseas empires. ${ }^{40}$

Assessment of Ruthenia as an imagined colonial space can be further enhanced through engagement with Edward Said's term Orientalism. In his ground-breaking study Said showed how deeply impressions of the Orient are entrenched in European culture, while focusing on the essential significance of studying cultural influence in colonial situations. Said defines Orientalism as a "discipline by which European culture was able to manage - and even produce - the Orient politically, sociologically, militarily, ideologically, scientifically and imaginatively." 41 For Said, this European construction of the Orient requires deep cultural processes involved in labeling non-European peoples as "Other": "a collective notion identifying 'us' Europeans against all 'those' non-Europeans, [...] the idea of European identity as a superior one in comparison with all the non-European peoples and cultures." ${ }^{42}$ His analysis anticipates the construction of an Other based on civilizational and cultural superiority; in the case of Ruthenia, the Czech elite cast themselves as Slavic heroes bringing modernity and western values to a backwards region impoverished by Hungarian neglect.

Maria Todorova's influential term "Balkanism," developed as a regional variant of Orientalism, holds a number of similarities to the case of Czechoslovak Ruthenia. Todorova developed the concept to express how the West has perceived the Balkan peninsula as uncivilized as a means of reinforcing its own cultural superiority. ${ }^{43}$ Todorova has established a set of distinctions which differentiate Orientalism from Balkanism. While Said presents the Orient and its relationship with the West as a sharp separation between two separate worlds with no overlapping features, Balkanism places western views of the Balkans in a "grey area" between these two extremities, a region which Westerners perceived as a potential bridge linking East and West. ${ }^{44}$ The metaphor of a bridge between two worlds also extends to stages of development, so the Balkans has received labels such as half-Oriental, half-civilized, and semi-

\footnotetext{
${ }^{40}$ Sarah Lemmen, "Noncolonial Orientalism? Czech Travel Writing on Africa and Asia around 1918," in Deploying Orientalism in Culture and History: From Germany to Central and Eastern Europe, James Hodkinson and John Walker, eds. (Rochester, N.Y.: Camden House, 2013), 209.

${ }^{41}$ Edward Said, Orientalism (New York: Vintage Books, 1978), 3.

${ }^{42}$ Said, Orientalism, 7.

${ }^{43}$ Maria Todorova, Imagining the Balkans (New York: Oxford University Press, 1997).

${ }^{44}$ Todorova, Imagining the Balkans, 15-16.
} 
colonial. ${ }^{45}$ Todorova also suggests that while the Balkans is a concrete and fixed geographical space in the minds of Western observers, the Orient and its perceived frontiers are unclear and malleable, an imagined space for Western observers. A further distinction lies in gender association; while Orientalism's Western fantasies of the East are distinctly female, Todorova suggests that Westerners see the Balkans as consistently male, unkempt and primitive. While Orientalism allows Westerners to categorize non-white and non-Christian peoples, Balkanism considers the perception of white and Christian peoples by white Westerners. Finally, Todorova suggests that true Orientalism requires the Orientals to internalize the perception of themselves as colonized people, but she believes people in the Balkans do not view their historical relationship with the West in colonial terms. ${ }^{46}$

Building on the foundational models of Orientalism and Balkanism, we can hypothesize a theoretical "Ruthenianism" to differentiate the colonial discourse in Carpathian Ruthenia. Many of Balkanism's prerequisites can apply to Ruthenia, such as a clearly-defined geographical space, white and Christian inhabitants, and rejection of colonial labelling by the inhabitants. The most distinctive feature of Ruthenianism lies in the nature of the "western" Czech observers; the Czech nation was linked to the Rusyn nation through common Slavic ethnicity, and they lived together within the borders of a single republic as fellow citizens. At the outset of Czechoslovakia the Czech nation aspired to the status of a Western nation, ${ }^{47}$ yet as Slavs they themselves formed part of less civilized Eastern Europe in Western thinking. ${ }^{48}$ Larry Wolff, Kristin Kopp and others have shown that the geographic boundaries dividing civilized Western Europe and the uncivilized Orient have never been clearly defined, leaving both Czechs and Rusyns in the transition zone. ${ }^{49}$ Thus Milica Bakić-Hayden's concept of Nesting Orientalisms entails a spectrum of levels of Orientalism which can apply within the state borders of Czechoslovakia, with Czechs, Slovaks and Rusyns forming a civilizational hierarchy. ${ }^{50}$ Attention must also be given to the dual nature of Slovakia's place in the Czech colonial imagination, as

\footnotetext{
${ }^{45}$ Todorova, Imagining the Balkans, 16.

46 Todorova, Imagining the Balkans, 3-20.

${ }^{47}$ Czech aspirations to be considered part of the West are discussed in detail in chapter 1.

${ }^{48}$ Larry Wolff, Inventing Eastern Europe: The Map of Civilization on the Mind of the Enlightenment (Stanford: Stanford University Press, 1994), 8, 300.

${ }^{49}$ Wolff, Inventing Eastern Europe, 6-10; Kopp, Germany's Wild East, 202.

${ }^{50}$ Milica Bakić-Hayden, "Nesting Orientalisms: The Case of Former Yugoslavia," Slavic Review (54/4, 1995), 917931.
} 
Slovaks sometimes appeared as equal partners within a Czechoslovak nation and sometimes as a backwards nation which required Czech guidance just as much as Rusyns.

Ruthenianism holds a further distinguishing feature: Czechs imagined Rusyns as both half-Oriental and purely Oriental. Examples of this duality in Czech thinking, with Ruthenia viewed as both a potential bridge to the East and as a hopelessly backwards Oriental territory, appeared in the media and academic studies throughout the era of the First Czechoslovak Republic. Descriptions of Ruthenia as half-Oriental suggest hopes that Rusyns, as a fellow Slavic people, could learn and improve by Czech example. However, Ruthenia also appeared as purely Oriental in character when Czechs intended to point out the huge gap in cultural and economic development between themselves and Rusyns while asserting their claim for recognition as part of the civilized West. These two narratives struggled for dominance in the Czech mindset, particularly during the first decade of the republic as Czechs first developed an awareness of Ruthenia and its people.

A working definition for Ruthenianism must also rest on clear definitions for the terms imperialism and colonialism. Debate over exactly how to define imperialism has continued unabated since the early twentieth-century work of J.A. Hobson and V.I. Lenin, who provided opposing viewpoints on the origins of European empires from liberal and Marxist perspectives. ${ }^{51}$ Charles Reynolds, following Joseph Schumpeter, has claimed that there are "imperialisms rather than imperialism" and that standing on any single working definition merely invites disagreement as to the terminology and its applicability. ${ }^{52}$ Patrick Wolfe has also highlighted the imprecision of the word imperialism, claiming that it is often used as a catch-all term to describe various theories of Western domination, including Marxism, dependency theory, postcolonialism and globalization. ${ }^{53}$ The modern study of imperialism has subsequently fragmented into many subcategories and types, focusing on specific economic, cultural and social structures.

\footnotetext{
${ }^{51}$ Vladimir Lenin, Imperialism: The Highest Stage of Capitalism (Sydney: Resistance Books, 1999); J.A. Hobson, Imperialism: A Study (New York: J. Pott \& Company, 1902).

${ }^{52}$ Charles Reynolds, Modes of Imperialism (Oxford: Martin Robertson, 1981), 1.

53 Patrick Wolfe, "History and Imperialism: A Century of Theory, from Marx to Postcolonialism," American Historical Review (April 1997), 388-420.
} 
Both imperialism and colonialism involve the subjugation of one people by another, but many scholars have warned against the impulse to treat these words as synonyms. ${ }^{54}$ According to Osterhammel, colonialism "might appear to be one special manifestation of 'imperialism'."55 Definitions which attempt to clarify the difference between the terms usually focus on the process of settlement; Charles Reynolds defines colonialism as a distinct term because it "denotes the settlement of territory by the peoples of the metropolitan power" while imperialism does not necessarily imply the settlement of land. ${ }^{56}$ Osterhammel's influential definition also focuses on the aspect of occupation as the key difference, calling it a "relationship of domination between an indigenous (or forcibly imported) majority and a minority of foreign invaders," while stressing that imperialism is planned by government ministries in the metropole, whereas colonialism is conducted by "special colonial authorities and "men on the spot'."57 Said similarly considers imperialism to be "the practice, the theory, and the attitudes of a dominating metropolitan centre ruling a distant territory" while defining colonialism as "the implanting of settlements on a distant territory" a process which is "usually a consequence of imperialism."58 Since many thousands of Czech officials, gendarmes and teachers moved to Ruthenia to conduct the region's affairs, according to the definitions of Said and Osterhammel it is possible to consider the relationship between Czechs and Rusyns as a potential case of colonialism (material colonialism in this sense), rather than imperialism. ${ }^{59}$

Among the various theoretical forms of colonialism, "internal colonialism" refers to colonialism within the borders of a single state and thus can bring insight to the political and economic power relationship in Czechoslovak Ruthenia. Michael Hechter developed the model of internal colonialism based on the economic principles at work between core and peripheral regions in Britain. ${ }^{60}$ Osterhammel has defined this type of colonialism as a form of domination which takes place not between a metropole and distant colonies, but between "centrally dominant

\footnotetext{
${ }^{54}$ See: Wolfe, "History and Imperialism: A Century of Theory, from Marx to Postcolonialism," 388; Robert J. C. Young, Postcolonialism: An Historical Introduction (London: Blackwell, 2001), 16.

${ }^{55}$ Osterhammel, Colonialism: A Theoretical Overview, 22.

${ }^{56}$ Reynolds, Modes of Imperialism, 1.

${ }^{57}$ Osterhammel, Colonialism: A Theoretical Overview, 16-17, 22.

${ }^{58}$ Edward Said, Culture and Imperialism (London: Vintage Books, 1994), 8.

${ }^{59}$ Statistics provided in: Jaromír Nečas, Politická situace na Podkarpatské Rusi (rok 1921) (Prague: Společnost přátel Podkarpatské Rusi, 1997), 51.

${ }^{60}$ Michael Hechter, Internal Colonialism: The Celtic Fringe in British National Development 1536-1966 (Los Angeles: University of California, 1975).
} 
and dependent peripheral regions within the borders of a single national state." ${ }^{, 61}$ The key difference between internal colonialism and external forms of colonialism is, according to Barrera, Muñoz and Ornelas, that internal colonialism occurs when "domination or exploitation of a distinct group is maintained even though the colonized have the same formal legal status as the colonizer," while external colonialism exists when there are clearly separated legal statuses for both the colonized and colonizer. ${ }^{62}$ Rusyns may have appeared to be on a different civilizational level in Czech eyes but they still held all the same legal rights as other citizens of the Czechoslovak state. Rusyns had equal voting rights (beginning with local elections in 1923) and open access to higher education and employment in Prague and other parts of the republic. ${ }^{63}$ However, despite holding equal legal status and a right to political and cultural autonomy enshrined in the constitution, Rusyns would not achieve full autonomy until 1938.

An additional form of colonialism relevant to Czechoslovak Ruthenia is what Osterhammel has called "compassionate colonialism," a concept which justifies colonialism as a beneficial and necessary form of education for the colonized. The practice permitted European colonizers to see their overseas activities as guidance and training for colonized territories which would eventually be able to rule themselves:

By steadfast pedagogical influence on the still 'immature' non-European peoples - 'peoples not yet able to stand by themselves under the strenuous conditions of the modern world' - a compassionate colonialism would at some undetermined point in the future be rendered superfluous. ${ }^{64}$

By the end of World War One, a new era of "liberal imperialism" tried to mask the problems of overseas colonialism in benevolent rhetoric. ${ }^{65}$

The era of compassionate colonialism or liberal imperialism grew in part from the right to self-determination popularized by Woodrow Wilson in his Fourteen Points in 1918. He called for "free, open-minded and absolutely impartial adjustment of all colonial claims," and demanded that the wishes of colonized peoples "must have equal weight with the equitable claims of the

\footnotetext{
${ }^{61}$ Osterhammel, Colonialism: A Theoretical Overview, 17.

${ }^{62}$ As quoted in: Fred A. Cervantes, "Chicanos as a Postcolonial Minority: Some Questions Concerning the Adequacy of the Paradigm of Internal Colonialism," in Latina Thought, Francisco Hernández Vázquez and Rodolfo Torres, eds. (Lanham, Maryland: Rowman and Littlefield, 2003), 333.

${ }^{63}$ Magocsi, The Shaping of a National Identity, 205.

${ }^{64}$ Osterhammel, Colonialism: A Theoretical Overview, 35.

${ }^{65}$ Osterhammel, Colonialism: A Theoretical Overview, 35.
} 
government whose title is to be determined. ${ }^{, 66}$ Although the European colonial powers could draw a distinction between permitting self-determination for subject European nations and not permitting it for non-European peoples, Wilson's concept left a lasting impression on both colonial rulers and the colonized. As historian Erez Manela has shown, colonized peoples around the world embraced the concepts of Wilsonian self-determination as they saw "little reason that they should not apply outside Europe as well as within it" and noted the "sweeping, universal terms" applied to it in the speeches of Wilson and British Prime Minister David Lloyd George towards the end of the First World War. ${ }^{67}$

In light of developments in interwar Ruthenia, compassionate colonialism appears an appropriate term to describe the Prague government's intentions towards Rusyns. Promises to grant autonomy for Rusyns always came with the requirement that their cultural level must be raised first. ${ }^{68}$ Czech elites went to great lengths to show the world the advantages that Czechoslovakia had brought to the inhabitants of Ruthenia, pointing to improvements in education and health care. ${ }^{69}$ An important component of liberal imperialism suggests that colonizers will justify their right to colonize by claiming to bring justice and stability to the colonized territory, what Osterhammel calls a "utopian vision of a purifying administration that obliterates corruption and inefficiency." ${ }^{, 70}$ Czech newspaper articles and government reports from the 1920s often chastised the former Hungarian rulers of Ruthenia while extolling the virtues of the new Czechoslovak administration. ${ }^{71}$ Justifying Czechoslovakia's moral right to occupy Ruthenia became more necessary in the 1930s; international pressure, particularly from Hungary and Poland, led to a government campaign to promote the benefits the republic had provided for Rusyns.

Scholars have already applied the concept of mission civilisatrice [civilizing mission] to the study of colonialism within Europe, and the term can equally be applied to Czechoslovak Ruthenia. Mission civilisatrice developed as a French assimilationist ideology that intended to

\footnotetext{
${ }^{66}$ Woodrow Wilson, "The Fourteen Points," Essential Writings and Speeches of the Scholar-President (New York: NYU Press, 2006), 404.

${ }^{67}$ Erez Manela, The Wilsonian Moment: Self-Determination and the International Origins of Anticolonial Nationalism (New York: Oxford University Press, 2007), 11.

${ }^{68}$ Magocsi, The Shaping of a National Identity, 201.

${ }^{69}$ The Czechoslovak government's foreign diplomacy in defense of Ruthenia is discussed in chapter 8 .

${ }^{70}$ Osterhammel, Colonialism: A Theoretical Overview, 108.

${ }^{71}$ Such comparisons with the previous Hungarian regime are discussed in chapter 1.
} 
foster the French culture among their colonial subjects. The related term rayonnement [radiance] described the French belief that they were destined to light the way for other non-European races. These terms became important bywords during French and Portuguese colonial rule in the nineteenth and early twentieth centuries. ${ }^{72}$ British historian Robert Young has described the European justification for a mission civilisatrice based on civilizational superiority:

Colonial and imperial rule was legitimized by anthropological theories which increasingly portrayed the peoples of the colonized world as inferior, childlike or feminine, incapable of looking after themselves (despite having done so perfectly well for millennia) and requiring the paternal rule of the west for their own best interests. ${ }^{73}$

Larry Wolff has used the term mission civilisatrice to describe Galicia in the Habsburg imperial imagination, with Galicia cast as a "Slavic Orient" in the eyes of political elites in Vienna. He sees the cultural label "Halb-Asien" [Half-Asian] applied to Galicia in the late nineteenth century as part of a "civilizing mission" for the Slavic peasants and Hasidic Jews of the territory. ${ }^{74}$ In a similar vein, a number of historians consider the relationship between southern and northern Italy after nineteenth-century unification as a form of mission civilisatrice. Jane Schneider's edited volume Italy's 'Southern Question': Orientalism in one Country incorporates studies of the "Orientalization" of the south by analyzing the writings of both northerners and southerners. ${ }^{75}$ Such studies provide a further example of colonial theory applied to relations between members of the same ethnic background within the borders of a single state.

Scholarly studies describing a mission civilisatrice in Habsburg Bosnia and Herzegovina have particular resonance for Czechoslovak Ruthenia. As former citizens of Austro-Hungary, the Czech elite sometimes compared their relationship with Ruthenia to the Habsburg annexation of Bosnia in 1908; numerous Czech officials and gendarmes in Ruthenia had also previously held posts in Habsburg Bosnia. ${ }^{76}$ Historian Robin Okey claims that the Habsburg administration in Bosnia can "be best understood in the context of imperialism," along with "the debate engendered by Edward Said's thesis on the 'Orientalist' stereotypes that he saw westerners

\footnotetext{
${ }^{72}$ Pratima Prasad, Colonialism, Race, and the French Romantic Imagination (London: Routledge, 2009), 12.

${ }^{73}$ Robert J. C. Young, Postcolonialism: A Very Short Introduction (New York: Oxford University Press, 2003 ), 2.

${ }^{74}$ Larry Wolff, The Idea of Galicia: History and Fantasy in Habsburg Political Culture (Stanford: Stanford University Press, 2010). See also: Larry Wolff, Inventing Eastern Europe: The Map of Civilization on the Mind of the Enlightenment (Stanford: Stanford University Press, 1994).

${ }^{75}$ Jane Schneider, ed., Italy's Southern Question: Orientalism in One Country (New York: Berg, 1998).

${ }^{76}$ The transition made by these officials from Bosnia to Ruthenia is described in chapter 5.
} 
imposing on the eastern, particularly the Islamic world."77 Similarly, Robert Donia has studied the cultural and political influence of the Austrian administration in a territory which he claims was broadly perceived by Austria-Hungary's citizens as part of the Orient. ${ }^{78}$ Okey and Donia's confidence in proclaiming Habsburg control of Bosnia as a colonial situation rests partly on the fact that a large proportion of the territory's population was Muslim and had formerly belonged to the Ottoman Empire.

This study of Czechoslovak Ruthenia pairs these approaches to colonial and imperial theory with a range of historical sources gathered during archival research in the Czech Republic in 2013 and 2015. Government documents from the Czechoslovak interior ministry, foreign ministry, education ministry, presidential office, regional administration office in Uzhhorod/Užhorod and regional offices in Ruthenia provide insight into the day to day workings of the state administration and policy decisions. These government sources are further enhanced by parliamentary and senate speeches, personal letters, academic articles and books by Czech scholars, officials and political leaders. The author tracked down several thousand newspaper and magazine articles from and about Czechoslovak Ruthenia during the research for this study; Rusyn newspapers published in Uzhhorod and Mukacheve/Mukačevo provide a daily window into political opinions and developments through the eyes of the intellectuals and political parties they represented. Czech newspapers and magazines from the period similarly reflect the interests of the various political parties which backed them, providing views of Ruthenia from all parts of the Czechoslovak political spectrum. Czech cultural sources on Ruthenia include tourist guidebooks, travellers' accounts, novels, cartoons, poetry and films, all of which offer meaningful insight into the Czech-Rusyn relationship through the medium of entertainment. A similar range of Rusyn sources, particularly political speeches, campaign posters, personal letters and books shed light on the Rusyn reaction to Czech rule and Czech perceptions of them as a colony.

This study includes eight chapters which alternate between viewing the relationship from the Czech perspective and the Rusyn perspective during the interwar period. The first two

\footnotetext{
${ }^{77}$ Robin Okey, Taming Balkan Nationalism: The Habsburg 'Civilizing Mission' in Bosnia 1878-1914 (Oxford: Oxford University Press, 2007), vii.

${ }^{78}$ Robert J. Donia, Islam under the Double Eagle: The Muslims of Bosnia and Herzegovina 1878-1914. (New York: Columbia University Press, 1981).
} 
chapters contrast Czech and Rusyn expectations and experiences of their relationship in the first few years of the republic. The opening chapter introduces the differing experiences of Czechs and Rusyns in Austro-Hungary, then analyzes the Czech elite's transition to their role as leaders in Czechoslovakia and how a Czech humanitarian mission for Rusyns formed from Slavic ideals. The second chapter focuses on the shift in thinking among Rusyn intellectuals from initial jubilation on joining the republic to growing disillusionment over the denial of political autonomy. Their list of grievances against the Prague government grew to include concerns about Czechization of the school system and regional bureaucracy, inability to find employment in a local administration dominated by Czechs, and settlement of Czech legionaries as colonists on farmland in Ruthenia.

Chapters three and four describe the formation of a discursive colonial relationship between Czechs and Rusyns. The third chapter presents how Czechs imagined Rusyns in the mold of colonial stereotypes by calling them childlike, passive, lazy and naturally inferior, and the role of stereotypes in shaping Czech public opinion of Ruthenia. These stereotypes framed a shift in the Czech imagination from their role as Slavic caregivers for Rusyns to a mission civilisatrice for less-civilized peoples. Chapter four analyzes how Czechs and Rusyns imagined their relationship as a colonial encounter through comparisons to colonial regions such as Africa and the Orient. Czech application of such metaphors served to dramatize the civilizational divide between the western and eastern regions of the republic while justifying the Prague government's decision to deny Rusyn autonomy. Rusyn intellectuals responded by comparing the Czech officials who ruled them to self-serving colonizers in Africa or India.

The fifth and sixth chapters focus on the significance of two individuals on Czech-Rusyn relations, Czech official and publisher František Svojše and Czech Communist author Ivan Olbracht. Chapter five focuses on the experiences of Czech officials working in Ruthenia, highlighting the shift in Rusyn perceptions of Czech administrative behaviour from humanitarian to imperialist. Significant cases of corruption among the officials added to Rusyn displeasure. The chapter highlights the behaviour of Svojše as a symbol of Czech chauvinism and arrogance among state officials in the eyes of Rusyns. The sixth chapter covers the Czech anti-colonial movement among Communists and left-wing authors who reacted to the imperialist character of the Czech administration in Ruthenia. Olbracht became the most influential figure in the 
movement, expressing criticism of the Prague government's policies in numerous books based on his personal experiences in Ruthenia.

The final two chapters cover the strained relationship between Rusyns and the Prague government during the last years of the First Czechoslovak Republic. Chapter seven outlines the Rusyn struggle for autonomy and resistance of Czechization until the achievement of an independent parliament following the Munich Agreement in 1938. The eighth chapter describes the Czech fear of imperial loss, analyzing how Czech media and politicians defended Czech rule in Ruthenia against international criticism and responded to the threat posed by the Hungarian revisionist movement. The final chapter also covers developments in Czech-Rusyn relations after the granting of Rusyn autonomy leading up to the dissolution of the republic and Ruthenia's reincorporation into Hungary in March 1939. 


\section{Chapter 1}

\section{Slavic Benefactors for a Poor Nation}

The creation of the Czechoslovak republic in October 1918 formed a new mindset among both Czech and Rusyn intellectuals. After centuries of playing a secondary role in the AustroHungarian Empire, the Czech nation took on a leadership position as the dominant ethnic group in a new state with many national minorities. The small Rusyn intelligentsia had faced cultural and political subjugation in the decades before the collapse of Austro-Hungary, and their initial hope for a better future in Czechoslovakia stemmed from the shared Slavic ethnicity of Czechs and Slovaks. The Czech Neo-Slav movement, building on a long tradition of Slav solidarity, had encouraged cooperation with other Slav nations of Austro-Hungary and Russia in the years leading to the First World War. ${ }^{1}$ The unexpected decision by the Allies at the Paris Peace Conference to include the territory of Ruthenia in Czechoslovakia offered a chance to bring another poor Slavic nation under Czech tutelage. Czechs celebrated the eastward expansion of the republic and welcomed the Slavic Rusyns as brothers in their new home where a bright future awaited in partnership with Czechoslovaks. Despite these expressions of goodwill and Slavic solidarity, a paternal relationship developed due to the extreme imbalance in levels of economic and cultural development between Czechs and Rusyns. This outlook developed in spite of previous Czech experiences as an oppressed nation within Austro-Hungary.

This chapter presents the establishment of the Czech role as Slavic benefactors and leaders for the Rusyn nation at the outset of the republic. Rusyns had been among the poorest inhabitants in the Austro-Hungarian Empire, and the most immediate requirements for the bulk of the population were basic needs such as food and medicine. The Czechoslovak Red Cross became one of the most important organizations in the region, providing food, provisions and medical care to Rusyn peasants living on the edge of starvation in the highland region. Many Czech teachers and administrators also headed east to Ruthenia, eager to help the Rusyn people in their development. These Czech workers came not only to work for the betterment of the republic but potentially for a greater Slavic cause. Early encounters with the challenging

\footnotetext{
${ }^{1}$ See: Paul Vyšný, Neo-Slavism and the Czechs 1898-1914 (London: Cambridge University Press, 1977).
} 
conditions in the region merely called for greater Slavic solidarity and Czech organizational skills, a test for the Prague government's leadership capabilities. Czech officials blamed the former Hungarian regime for obstacles they encountered, while progress was trumpeted at home and abroad as work for the cause of Slavdom and the republic.

\section{Ruthenia under Hungarian Rule}

Since the Middle Ages the mostly mountainous region of Ruthenia had formed part of the Hungarian kingdom, and as an economic backwater it remained among the poorest and leastdeveloped regions in nineteenth-century Austro-Hungary. ${ }^{2}$ Rusyns faced a struggle for physical survival in the unfavourable economic conditions of the Carpathian highlands, with $90 \%$ employed as subsistence farmers, shepherds and woodcutters in 1910. In that year the number of Rusyns working in professional positions such as teachers, notaries and journalists was less than $1 \% .^{3}$ Seasonal employment harvesting the fields of the Hungarian plains provided an essential source of income for highland Rusyn families, while Hungarians, Jews and Germans dominated the few industries in the region.

The ethnographic composition of Ruthenia at the turn of the twentieth century included many ethnic groups other than Rusyns. Hungarian government statistics for 1910 recorded a population of $56 \%$ Rusyns, 30\% Hungarians, $11 \%$ Germans, 3\% Romanians and $1 \%$ Slovaks. ${ }^{4}$ These politically contestable figures counted the sizeable Jewish population as Hungarians; equally contestable Czechoslovak government statistics for 1921 would record 62\% Rusyns [described as Ruská], 17\% Hungarians, 13\% Jews, 3\% Czechoslovaks and 2\% Germans. ${ }^{5}$ Small populations of Poles and Roma also added to the diverse ethnic mix. Despite constant emigration, the region's total population also increased significantly from 395,000 to 604,000

\footnotetext{
${ }^{2}$ Maria Meyer, The Rusyns of Hungary: Political and Social Developments 1860 - 1910 (New York: Columbia University Press, 1997), 4.

${ }^{3}$ Magocsi, The Shaping of a National Identity, 14.

${ }^{4}$ C.A. Macartney, Hungary and her Successors: The Treaty of Trianon and Its Consequences (London: Humphrey Milford, 1937), 203.

${ }^{5}$ Statistics given in Emanuel Chalupný and Dobroslav Krejčí, eds., Slovník národohospodářský sociální a politický (Prague: Otakar Janáček, 1933), 220.
} 
between 1880 and 1921. ${ }^{6}$ Hungarians lived predominantly in the major cities and in the agriculturally productive lowland regions, which formed a continuation from the Hungarian plains to the south. ${ }^{7}$ An ethnic migration in the late nineteenth and early twentieth century had brought large numbers of Hasidic Jews from Galicia to Ruthenia, and they quickly became integrated into the local economy as merchants, moneylenders and tavern owners. ${ }^{8}$

In this multi-ethnic environment a small group of Rusyn intellectuals, mostly Greek Catholic priests, had taken their first steps towards national autonomy during the 1848 revolution in the Habsburg Empire. Rusyn leader Adolf Dobrians'kyi worked together with Slovak and Galician nationalists in an attempt to gain more cultural and linguistic rights within the structure of the Hungarian state. Slovak leader Jozef Hurban initially represented Rusyns in their demands, but Dobrians'kyi and a Rusyn delegation travelled to Vienna in October 1849 to lobby directly on their own behalf. ${ }^{9}$ Dobrians'kyi asked the Habsburg government to introduce the local Rusyn speech into the public schools of Ruthenia, to establish new districts of administration based on nationality, and to appoint more officials of Rusyn ethnicity. ${ }^{10}$ For a brief time Dobrians'kyi became vice-administrator of Uzhhorod/Ungvár district, and some measure of Rusyn political autonomy seemed possible. ${ }^{11}$ However, the return of full Habsburg strength two years later ended any such hopes.

Contact with great Russians during the 1848 revolution influenced the national consciousness of Rusyns. Russian soldiers who arrived on Hungarian territory to help the Habsburgs suppress the Magyar revolution received a warm welcome from Rusyn peasants, who found they could communicate easily with the soldiers in their own local speech. ${ }^{12}$ Czechoslovak Foreign Minister and academic Kamil Krofta described the impact of this contact with Russian troops on Rusyn nationalism: "Their presence in the Carpathians brought about a messianic

\footnotetext{
${ }^{6}$ Chalupný and Krejčí, eds., Slovník národohospodářský sociální a politický, 221. These population statistics are also contestable and may reflect different census taking techniques as well as political intentions.

${ }^{7}$ Paul Robert Magocsi, A History of Ukraine (Toronto: University of Toronto Press, 1996), 604.

${ }^{8}$ For a study of the Jews of Ruthenia see Yeshayahu Jelinek, The Carpathian Diaspora: The Jews of Subcarpathian Rus and Mukachevo (New York: Columbia University Press, 2007).

${ }^{9}$ Magocsi, The Shaping of a National Identity, 44.

${ }^{10}$ Robert Kann and David Zdaněk, The Peoples of the Eastern Habsburg Lands, 1526-1918 (Seattle: University of Washington Press, 1984), 416.

${ }^{11}$ Kamil Krofta, Carpathian Ruthenia and the Czechoslovak Republic (London: Eyre and Spottiswoode, 1936), 2021.

${ }^{12}$ Magocsi, The Shaping of a National Identity, 45.
} 
Russophilism - that fanatical belief in help from Russia which henceforward became the distinguishing feature of all intellectual movements." ${ }^{\prime 13}$ This would remain the case until a Rusyn Ukrainophile movement led by Greek Catholic priest Avhustyn Voloshyn developed in the early twentieth century. ${ }^{14}$

Although the 1848 revolution did not directly achieve any of the political aims of Dobrians'kyi and the Rusyn intelligentsia, the next two decades offered enough cultural freedom to permit the growth of a distinct Rusyn consciousness among the intelligentsia. After the revolution Rusyn authors began to write more frequently in the local peasant speech and Russian instead of Hungarian, a process influenced by Aleksander Dukhnovych, known to Rusyns as their cultural awakener. Under his guidance a Rusyn literary society appeared in Prešov/Eperjes/Priashiv in 1850, and in 1851 some classes of the gymnasium in Uzhhorod/Ungvár began using Rusyn as the language of instruction. ${ }^{15}$ By the 1860s two important trends had developed among the intelligentsia, firstly the idea of political cooperation with Slovaks, ${ }^{16}$ and secondly the use of Slavic languages for Rusyn publications rather than exclusively Hungarian.

Following the Austro-Hungarian Ausgleich [Compromise] of 1867, the Hungarian government received the right to run its own internal affairs without intervention from Vienna, a development which had a sharply negative impact on cultural rights for Rusyns. Policies of Magyarization caused a sharp reduction in the number of schools in Ruthenia offering lessons taught in the local Rusyn speech, especially after 1900. The number of elementary schools with Rusyn language instruction fell from 353 in 1870 , to 64 in 1903 , to just 18 by $1910 .{ }^{17}$ Rusyn cultural institutions came under increased pressure, and positions in city and regional administrations became occupied almost exclusively by ethnic Hungarians. ${ }^{18}$

Some Rusyn intellectuals assimilated under the influence of Magyarization. The Rusyn clergy who had helped to foster a Rusyn consciousness faced pressure to join the Magyar

\footnotetext{
${ }^{13}$ Krofta, Carpathian Ruthenia and the Czechoslovak Republic, 21.

${ }^{14}$ Kann and Zdaněk, The Peoples of the Eastern Habsburg Lands, 419.

${ }^{15}$ Magocsi, The Shaping of a National Identity, 48.

${ }^{16}$ Alexander Maxwell, "Fickle Nationalism and Slovakia's Shifting Ethno-Linguistic Borders," in The Palgrave Handbook of Slavic Languages, Identities and Borders, Tomasz Kamusella, Motoki Nomachi, Catherine Gibson, eds. (London: Palgrave, 2015), 237-240.

${ }^{17}$ Kann and Zdaněk, The Peoples of the Eastern Habsburg Lands, 418.

${ }^{18}$ Kann and Zdaněk, The Peoples of the Eastern Habsburg Lands, 418.
} 
intelligentsia, and as a result they became partly disconnected from the concerns of the Rusyn peasants who formed their parishes. ${ }^{19}$ Such Rusyn intellectuals adopted Hungarian culture, language, and national loyalty as their own. Rusyn scholarly and scientific work produced during this period appeared almost entirely in Hungarian, while educated Rusyns read and contributed to Hungarian-language newspapers. ${ }^{20}$ In an attempt to eliminate Rusyn use of the Cyrillic alphabet, the government introduced a form of the Latin alphabet based on Magyar script in 1915 , and its use became mandatory in $1916 .^{21}$

A limited form of social protest existed among the Rusyn peasantry through their willingness to convert from Greek Catholicism to the Orthodox faith, an act with Russophile overtones. For the government in Budapest, conversion to Orthodoxy signified an oath of loyalty to the Russian Empire and had to be condemned. ${ }^{22}$ A trial held in Sighetu Marmației/Máramarossziget/Marmaroš Sihot in 1914, later known as the Marmaroš Trial, accused 94 Rusyn peasants of treason against the Hungarian state for converting to Orthodoxy. The trial found 32 of the peasants guilty and sentenced them to prison terms of up to four and a half years. ${ }^{23}$

Despite such well-publicized trials, the majority of the Rusyn population did not concern itself with cultural and political developments as their interests remained focused on mere physical survival. Life was bitterly hard for Rusyns trying to make a living as farmers and shepherds in the highland region, leaving them largely indifferent to the national movement among Rusyn intellectuals. ${ }^{24}$ A combination of poor farmland, failed harvests and natural population growth made starvation a significant risk by the early twentieth century. Many of these highland peasants descended from the hills each autumn to head to the market squares of Debrecen, Nyíregyháza and other cities on the Hungarian plains where they would offer their labour for the harvest period. In 1898 the government of Hungary created a program called the hegyvidéki akció [Highlands Campaign] to lessen the economic hardship of the highland Rusyn

\footnotetext{
${ }^{19}$ Macartney, Hungary and her Successors, 209.

${ }^{20}$ Krofta, Carpathian Ruthenia and the Czechoslovak Republic, 21.

${ }^{21}$ Kann and Zdaněk, The Peoples of the Eastern Habsburg Lands, 423.

${ }^{22}$ Keith Dyrud, The Quest for the Rusyn Soul: The Politics of Religion and Culture in Eastern Europe and in America, 1890 - World War One (Philadelphia: Balch Institute Press, 1992), 87.

23 "Marmarošský proces," Národní listy (4 February 1914), 1.

${ }^{24}$ For a theoretical overview of national indifference, see Tara Zahra, "Imagined Non-Communities: National Indifference as a Category of Analysis,” Slavic Review (Spring 2010, no. 1), 93-119.
} 
peasants. Led by Edmund Egán/Egán Ede, a Hungarian economist of Scottish background, ${ }^{25}$ the commission helped to coordinate the mass movement of Rusyn farm labourers to the southern plains at harvest time and tried to improve the agricultural technology used in the mountain region, though the initiatives had minimal impact on living conditions. ${ }^{26}$

Despite the Highlands Campaign, the Rusyn peasants received little sympathy from their Hungarian rulers. British scholar C.A. Macartney claimed that in Hungarian eyes "Ruthenes were not thought fit for any better employment than lumbering, acting as ghillies on the huge deer forests which covered most of the country, or scratching a miserable livelihood out of the tiny plots left to them under the shadow of the trees." Macartney also described the humble living conditions he had observed in Rusyn villages during the final years of the Hungarian kingdom:

Only the nobleman or his bailiff driving to the castle passed between long rows of cabins built of log or clay, with floors of beaten earth and chimneyless roofs of decaying thatch; the smoke, eddying through the single room, revealed dim outlines of a promiscuous crowd of cows and children, geese and grandparents. In the muddy lane, half-naked infants fled from under his wheels, or grown men avoided them with greater difficulty as they strove to master the fiery brandy which formed their chief solace and a large proportion - and perhaps the most sustaining part - of their diet. ${ }^{27}$

Faced with starvation, economic neglect and a growing population, large numbers of Rusyns decided to emigrate abroad in hopes of achieving a better future.

Beginning in the late nineteenth century a significant part of the Rusyn population left to begin a new life in the United States. Between 1880 and 1914 perhaps 150,000 Rusyns migrated across the ocean to the north-eastern USA. ${ }^{28}$ Spread of anti-Hungarian sentiment among the Rusyn-American parishes concerned the Hungarian government, who wanted to ensure such ideas did not reach the Rusyn population still living in Upper Hungary. The Budapest government organized a project in 1902 to send Rusyn priests loyal to Hungary across the ocean

\footnotetext{
${ }^{25}$ Meyer, The Rusyns of Hungary: Political and Social Developments $1860-1910,117$.

${ }^{26}$ László Katus, Hungary in the Dual Monarchy 1867-1914 (New York: Columbia University Press, 2008), 463; see also Edmund Egán's description of the Ruthenian economy in: Edmund Egán, Hospodářský stav rusinských venkovanů v Uhrách (Prague: Rolnická tiskárna, 1922).

${ }^{27}$ Macartney, Hungary and her Successors, 204-205.

${ }^{28}$ Macartney, Hungary and her Successors, 202.
} 
to monitor the Rusyn-American parishes and limit the spread of anti-Magyar sentiment. ${ }^{29}$ However, during the First World War the large and increasingly prosperous and influential population of Rusyn-Americans would play an important role in determining the future status of their homeland.

With the outbreak of the war Rusyns in Ruthenia served in the army of Austro-Hungary, an experience which brought them into contact with other Slavs of the Empire. Interacting with Czechs, Croatians, Poles and other Slavs who spoke their languages proudly and possessed a strong national consciousness fostered similar feelings among Rusyn soldiers. ${ }^{30}$ Many Rusyns became prisoners on the eastern front in Russia and later joined the White or Red Russian armies. Interaction with Bolsheviks in Russia resulted in some Rusyns carrying these revolutionary ideas home with them to a sympathetic audience. ${ }^{31}$ Returning Rusyn soldiers had developed a worldview which went beyond the traditional Magyar-focused thinking in Ruthenia, and this exposure had a significant impact in the rapidly-changing social and political environment as Austro-Hungary dissolved at the end of the war.

Rusyn intellectuals faced Magyarization while the Rusyn peasantry languished in poverty and illiteracy under Hungarian rule in the late nineteenth and early twentieth centuries. Assimilation of the intelligentsia eroded the Rusyn national consciousness, while the risk of starvation left many with little option but to emigrate. The collapse of the Habsburg Empire offered Rusyns a chance to forge a new path, though politically well-connected RusynAmericans would prove to be the main drivers of change. Hope for a better future in cooperation with Czechs stemmed at least in part from Slavic idealism with its roots in the nineteenth-century writings of Ján Kollár. ${ }^{32}$ As we shall see, the Czech nation also faced persecution and struggled for independence in Austro-Hungary in the years leading up to the First World War.

\footnotetext{
${ }^{29}$ Meyer, The Rusyns of Hungary: Political and Social Developments 1860 - 1910, 204-208.

${ }^{30}$ Magocsi, The Shaping of a National Identity, 74.

${ }^{31}$ Rusinko, Straddling Borders: Literature and Identity in Subcarpathian Rus', 297.

${ }^{32}$ See: Ján Kollár, Reciprocity between the Various Tribes and Dialects of the Slavic Nation, trans. Alexander Maxwell (Bloomington, Indiana: Slavica, 2008).
} 


\section{From Followers to Leaders}

The economic and cultural achievements of the Czech nation greatly exceeded that of the Rusyns within Austro-Hungary, yet they also faced more limited forms of cultural and linguistic suppression under Habsburg rule. Before World War One the Czech intelligentsia's ambitions for political autonomy had seldom looked beyond federal reform in Austro-Hungary; their sudden transition from followers to leaders in Czechoslovakia would depend on skilled diplomacy abroad coupled with the unexpected collapse of Habsburg authority.

Towards the end of the nineteenth century, Czech nationalists sought greater linguistic rights under Austrian rule and fought national indifference among the population in Bohemia. ${ }^{33}$ The German language held a dominant position in Bohemia's administration and system of education, yet as Jeremy King has shown, for many citizens in the region deciding if they belonged to the Czech or German nation was not a major concern. ${ }^{34}$ In response to this apathy, Czech intellectuals with national aims wished to clearly define the linguistic frontiers of the Czech nation and to win as many converts as possible. ${ }^{35}$ Nationalist organizations encouraged Czech parents to send their children to Czech schools, despite the common historical preference to have children learn both languages. ${ }^{36}$ Nationalists declared that the state administration should communicate with each citizen in their own native language, ${ }^{37}$ and their anger over the language question was further heightened by the creation and subsequent cancellation of a measure intended to give the Czech language equal status with German in Bohemia's administration. Introduced by Count Kasimir Badeni in 1897, the ordinance was heavily opposed by Bohemian Germans who feared the loss of their dominant position in the regional administration. ${ }^{38}$ Protests by German-speakers in Bohemian cities and in the Vienna parliament eventually led to the fall of Badeni's government and the immediate cancellation of the language reforms in November

\footnotetext{
${ }^{33}$ See: Zahra, "Imagined Non-communities: National Indifference as a Category of Analysis," 93-119.

${ }^{34} \mathrm{King}$, Budweisers into Czechs and Germans, 2-3.

${ }^{35}$ Judson, Guardians of the Nation, 5.

${ }^{36}$ Tara Zahra, Kidnapped Souls: National Indifference and the Battle for Children in the Bohemian Lands, 1900 1948 (London: Cornell University Press, 2008), 13.

37 Jan Rychlík and Vladimír Penčev, Dějiny Českých zemí (Prague: Vyšehrad, 2013), 365-366.

${ }^{38}$ Nancy Meriwether Wingfield, Flag Wars and Stone Saints: How the Bohemian Lands Became Czech (Cambridge, Mass.: Harvard University Press, 2007), 48.
} 
1897. ${ }^{39}$ Czech nationalists in Bohemia responded to the decision by promoting a boycott of nonCzech goods. ${ }^{40}$

Despite such setbacks, Czech intellectuals and Czech nationalist sentiment grew in stature and confidence by the end of the nineteenth century, in line with increasing economic prosperity in industrialized Bohemia and Moravia. A new Czech branch of Charles University and a national theatre and museum in Prague helped to encourage a greater national consciousness and sense of pride among the public. ${ }^{41}$ The Czech Sokol movement, originally founded in 1862, became an important outlet for Czech national expression. Although devoted to gymnastics training, mass physical fitness gatherings organized by local branches created an awareness of national belonging. ${ }^{42}$ Future Czechoslovak foreign minister Edvard Beneš later claimed that the Czech nation had "succeeded by assiduous labour" in developing their national culture despite being "hindered continuously by the dynasty and Germans" in an age when "the hour of the Slavs" had "not yet struck.",

In the aftermath of the failed Badeni decrees, Czech intellectuals determined that they needed to develop contacts with Slavic allies both inside and outside of Austro-Hungary in order to bring additional pressure to bear on the Austrian authorities. ${ }^{44}$ Describing the main goals of Czech diplomacy in the years leading up to 1914, Edvard Beneš considered it "essential to take positive steps towards achieving the gradual political and economic strengthening of the Slav element in Austro-Hungary" in order to "bring about internal changes in the direction of federalism, which would place the Slavs in the majority and gain them ascendancy." 45 This involved backing the Poles in their drive for autonomy, and providing support for Serbs, despite the poor relations between the governments in Vienna and Belgrade. ${ }^{46}$ The need for allies would eventually spawn the Czech Neo-Slav movement which sought to develop further cooperation among the various Slavic minorities of Austro-Hungary and foster closer relations with Russia. The origins of Neo-Slavism lay with nineteenth-century Slav intellectuals such as Slovak Ján

\footnotetext{
${ }^{39}$ A.H. Hermann, A History of the Czechs (London: Chaucer Press, 1975), 104.

${ }^{40}$ Vyšný, Neo-Slavism and the Czechs 1898-1914, 4.

${ }^{41}$ Carol Skalnik Leff, National Conflict in Czechoslovakia (Princeton: Princeton University Press, 1988), 26.

${ }^{42}$ Josef Scheiner, "Sokolstvo," in Slovanstvo: Obraz jeho minulosti a prítomnosti, J. Polívka and J. Bidlo, eds. (Prague: Jan Laichter, 1912), 693.

${ }^{43}$ Edvard Beneš, Bohemia's Case for Independence (London: George Allen and Unwin, 1917), 77.

${ }^{44}$ Vyšný, Neo-Slavism and the Czechs 1898-1914, 17.

${ }^{45}$ Edvard Beneš, Úvahý o slovanství (Prague: Čin, 1947), 135.

${ }^{46}$ Vyšný, Neo-Slavism and the Czechs 1898-1914, 37.
} 
Kollár, who proposed that all Slavs belonged to one great Slav nation, and should unite through literary reciprocity [wzájemnost]. ${ }^{47}$

The cause of Neo-Slavism figured prominently in the political ideas of Karel Kramár and the Young Czech Party [Mladočeši] in the decade leading up to the First World War. Despite his Neo-Slav ambitions, Kramáŕ did not at first seek to bring down the Habsburg leadership; instead he wished to promote an Austro-Russian alliance to replace the Austro-German partnership and to develop political strength among the Austrian Slavs to rival the Austrian Germans. ${ }^{48}$ In 1890 he declared that "the strength of the Germans is founded on such a wide all-Austrian policy. We Slavs must imitate them." 49 A chance to develop such links arose during commemorations held to celebrate the centenary of "Czech awakener" František Palacký's birth in 1898. In an influential speech to representatives from many Slav nations, Kramár̆ declared that the festivities would be a "step towards a great future" for all Slavs and called on the delegates to collaborate for the advancement of Austrian Slavs. ${ }^{50}$ Kramáŕ's Pan-Slav ambitions gained momentum following the defeat of his Young Czech Party at the polls in 1907 and the annexation of Slavic Bosnia and Herzegovina by the Habsburgs in $1908 .^{51}$ He helped organize a series of Slav congresses in Prague, St. Petersburg and Sofia between 1908 and 1910 to promote development of the movement beyond the borders of Austro-Hungary. Strongly pro-Russian and with a Russian wife, Kramár hoped to foster the establishment of a future Pan-Slav state in which a Russian Romanov prince would rule. ${ }^{52}$

In contrast to Kramář's ambitions, Czech philosopher and future Czechoslovak President Tomáš Garrigue Masaryk was suspicious of political Pan-Slavism, as he considered it to be equivalent to Pan-Russianism. ${ }^{53}$ Masaryk had visited Russia several times, and claimed that he felt "love for the Russian people and dislike for the official policy and the ruling intelligentsia," while believing that Russia could not be relied upon to have Czech interests in mind. ${ }^{54}$ As a

\footnotetext{
${ }^{47}$ Kollár, Reciprocity between the Various Tribes and Dialects of the Slavic Nation, 73.

48 John Francis Nejes Bradley, "Czech Pan-Slavism before the First World War," The Slavonic and East European Review (December 1961, vol. 40, no. 94), 185.

${ }^{49}$ Karel Kramář, letter to J. Kaizl (2 October 1890), as quoted in Vyšný, Neo-Slavism and the Czechs 1898-1914, 30 .

50 "Banket k oslavě stých narozenin Františka Palackého," Národní listy (19 June 1898), 3.

${ }^{51}$ William Wallace, Czechoslovakia (London: Ernest Benn, 1976), 59.

${ }^{52}$ Hermann, A History of the Czechs, 145.

${ }^{53}$ Vyšný, Neo-Slavism and the Czechs 1898-1914, 33.

${ }^{54}$ Karel Čapek, Talks with T.G. Masaryk (North Haven, Connecticut: Catbird Press, 1995), 100.
} 
result his gaze turned westwards: "As a European I am a Westerner, and I say so for the benefit of the Slavophiles, who see in Russia and Slavdom something better than Europe. The best Russians were Westerners too!"55 Masaryk hoped that each national group of Austro-Hungary could achieve cultural and political autonomy, but not through political union among the Slavs. Speaking to a British audience in 1916, he claimed that "Panslavic centralization is not desirable, either from a geographical point of view or from the point of view of historical evolution," and advised that Czechs should "claim liberty and national independence" in the face of "oppression by Germanic nations." 56

However, Masaryk also spoke out against oppression of other Slavic minorities in Austro-Hungary, drawing particular attention to the 1908 annexation of Bosnia and Herzegovina. In 1910 he spoke of Austrian oppression in Bosnia in a speech to the federal assembly in Vienna. He claimed the inhabitants of Bosnia and Herzegovina were "shackled" [spoutána] both politically and economically by Austria's refusal to grant them constitutional rights. He also declared that the "annexation of the two provinces without the agreement of the nation was not legitimate" and claimed that it was "impossible to argue that the nation is not mature. If the nation is mature enough for taxation then it is also mature enough to decide its own future."57 Czech National Socialist leader Vaclav Klofáč expressed similar sentiments, while Czech deputies in the Bohemian parliament protested against the annexation claiming that the "inhabitants themselves should have decided in a plebiscite" rather than Austro-Hungary using "mere force." 58 The support of Masaryk and other Czech politicians for the "maturity" of the Bosnian nation to "decide its own future" would hold a particular resonance for the autonomy ambitions of the Rusyn nation within the future Czechoslovakia.

Following the outbreak of World War One, Masaryk went into exile abroad, where he campaigned on behalf of an independent state for the Czechs and Slovaks. Kramár remained in Prague and formulated his own plans for a future Pan-Slav state linking the Czech nation with

\footnotetext{
${ }^{55}$ Čapek, Talks with T.G. Masaryk, 102.

${ }^{56}$ T.G. Masaryk, The Slavs among the Nations (London: The Czech National Alliance in Great Britain, 1916 ), 18.

57 T.G.Masaryk, "Anexe a správa Bosny a Hercegoviny," in Rakouská zahraniční politika a diplomacie (Prague: Pokrok, 1911), 41-42.

58 “Protest proti annexi Bosny a Hercegoviny," Národní listy (16 October 1908), 1.
} 
Russia. $^{59}$ Kramáŕ's political agitation in favour of Russia led to his arrest by the Austrian authorities on charges of treason, and he spent much of the war sitting in a Vienna prison. He managed to escape execution only due to a timely amnesty issued following the death of Emperor Franz Joseph in November $1916 .{ }^{60}$ While Masaryk waged a successful diplomatic charm campaign in the USA, Beneš worked hard in Paris and London to build support for a Czechoslovak National Committee. Their carefully calculated diplomacy ensured that the Czech nation was placed among the Allies ready to enjoy the spoils of victory at the conclusion of the war.

Particularly significant to the Czechoslovak national cause was the role of the Czechoslovak Legion. Under Masaryk's guidance, Czech and Slovak soldiers deserted from the Austro-Hungarian army and formed legions ready to fight on the side of the Allied powers; Czech soldiers had little appetite for fighting on the side of Germany in a war against Slavic Russia and Serbia. ${ }^{61}$ Following the Bolshevik revolution, the Czechoslovak Legion based strategically along the Trans-Siberian railway in Russia received international praise and lent additional weight to the Czech delegation which would negotiate at the Paris Peace Conference. Czech-American publication Bohemian Review called the exploits of the Legion a "great Czechoslovak romance" which had "caught the imagination of the world." 62 The Legion received praise as an example of Czech leadership; Czechoslovak government official Petr Hatalak later claimed that the actions of the Czechoslovak Legion had proved that "of all the Slavs the Czechs have the best organizational skills."63

As the dream of statehood came within reach, goals differed among the Czech intelligentsia when determining which territories they should claim as part of a future Czechoslovak state. Masaryk initially considered including the Sorbs of Lusatia and a corridor to

\footnotetext{
${ }^{59}$ Wallace, Czechoslovakia, 102.; D. Perman, The Shaping of the Czechoslovak State: Diplomatic History of the Boundaries of Czechoslovakia, 1914-1920 (Leiden, Netherlands: E.J. Brill, 1962), 17.

${ }^{60}$ Hermann, A History of the Czechs, 127.

${ }^{61}$ Hermann, A History of the Czechs, 126.

62 "The Great Czechoslovak Romance," Bohemian Review (August 1918, vol. 2, no. 8), 113. For studies on the Czechoslovak Legion in Russia, see John Francis Nejes Bradley, The Czechoslovak Legion in Russia, 1914-1920 (New York: Columbia University Press, 1991); and Paul Jeffrey Rivas, The White Pawn of Siberia: The Czechoslovak Legion in Russia 1914-1920 (Milwaukee: University of Wisconsin, 1993).

${ }^{63}$ Petr Hatalak, Jak vznikla myšlenka připojiti Podkarpatskou Rus k Československu (Uzhhorod: Státní tiskárna, 1935), 22.
} 
ally Yugoslavia which would separate Austria from Hungary. ${ }^{64}$ The fate of the Czech minority in Vienna also received concern, though Masaryk and his ally Beneš eventually left all of these aims as secondary objectives; writing in April 1919, historian H.W. Seton-Watson considered it "wise" for the Czech leaders to differentiate between these territorial aims and the essential demands for Bohemia, Moravia and Slovakia. ${ }^{65}$ However, Kramář coveted considerably more land, including Lusatia, Kłodzko/Glatz, parts of Silesia and Galicia, Hungary’s Miskolc and Tokaj region, and a land border with Serbia; as historian William Wallace put it, "success had gone to his head."66 At the Paris Peace Conference Beneš attempted to dilute Kramářrs unrealistic aims, but at Kramáŕr's insistence he presented the case for a Czechoslovak Lusatia and a corridor to Yugoslavia in his speech to the delegates. He suggested that claiming these extra territories was not a priority for Czechoslovakia, but the Prague government would reluctantly agree to take the regions if it was the wish of the Entente powers. ${ }^{67}$ This proposal did not meet with success.

Some Czechs dreamed of even far greater territorial ambitions for the republic; Jan Havlasa, a Czech representative at the Peace Conference, even published a book proposing the possibility of a Czech overseas colony, specifically the former German colony of Togoland in West Africa. ${ }^{68}$ He further suggested that the idea of a Czech Kamchatka and a Czech New Guinea were not beyond the realm of possibility. ${ }^{69}$ Such enthusiasm reflected a growing belief in Czech leadership abilities and national confidence on the international stage. In the new post-war political reality, the Czech elite had to adjust to their role as leaders once their statehood ambitions had been fulfilled.

\footnotetext{
${ }^{64}$ R.W. Seton-Watson, "Czecho-Slovak Claims," in R.W. Seton-Watson and his Relations with the Czechs and Slovaks, Documents 1906-1951, Jan Rychlík et al, eds. (Banská Bystrica: Matica Slovenská, 1995), 292. For an analysis of Czech interest in Lusatia, see: Alexander Maxwell, "Edvard Beneš and the Soft Sell: Czechoslovak Diplomacy towards Lusatia, 1918-1919," Bohemia (2014, vol. 46), 348-367.

${ }^{65}$ R.W. Seton-Watson, "Czecho-Slovak Claims," 291.

${ }^{66}$ Wallace, Czechoslovakia, 132. For a detailed account of Kramáŕ’s territorial ambitions see Perman, The Shaping of the Czechoslovak State: Diplomatic History of the Boundaries of Czechoslovakia, 1914-1920, 17-19.

${ }^{67}$ Maxwell, "Edvard Beneš and the Soft Sell: Czechoslovak Diplomacy towards Lusatia, 1918-1919," 363.

${ }^{68}$ Havlasa, České kolonie zámořské, 12.

${ }^{69}$ Havlasa, České kolonie zámořské, 14-15.
} 


\section{Caring for Rusyns as a Slavic Duty}

Ruthenia did not form part of the initial territorial ambitions of the Czech leadership, and contact with Rusyn elites about the prospects for union did not occur until near the end of the war. Awareness of Rusyns among the broader Czech public increased during the Marmaroš treason trial in 1914. The case aroused considerable interest in the Bohemian lands and sympathy for the plight of the peasants caught in a political power struggle between Austro-Hungary and Russia. A future Czechoslovak Prime Minister, Slovak Milan Hodža, attended the trials as a journalist. ${ }^{70}$ The Czech media also showed support for the cause of these fellow Slavs; Národní listy called the trial "purely political" and part of "high politics in Budapest and Vienna."71 České slovo later recalled the trial at the time of Ruthenia's inclusion in the Czechoslovak Republic, claiming that Czechs had "watched the Marmaroš process with indignation" and saw that under Hungarian rule "the Carpathian Rusyns didn't have even the most basic cultural and economic conditions." 72

It was only in September 1918 following a meeting with a young American-Rusyn lawyer from Pittsburgh, Gregory Zhatkovych, that T.G. Masaryk considered the case for including the Rusyns of Ruthenia in the republic. The large number of Rusyn immigrants in America, some of whom had gained wealth and political power, gave them significant influence within the US administration, while the smaller group of Rusyn intellectuals in Ruthenia remained largely without an international voice. As head of the American National Council of Uhro-Rusyns, Zhatkovych had at first hoped to gain outright independence for their homeland or union in a future state with Ruthenians from Galicia and Bukovina, and lobbied US President Woodrow Wilson for support. ${ }^{73}$ However, Wilson considered Rusyn independence to be inadvisable and suggested to Zhatkovych that he begin negotiations with Masaryk about joining Czechoslovakia as an autonomous territory. Following negotiations with Masaryk, Zhatkovych claimed the Czech leader had guaranteed that "if the Rusyns decide to join the Czechoslovak

\footnotetext{
${ }^{70}$ Milan Hodža, “U karpatských Rusov,” in Články, reči, štúdie, vol. 3 (Prague: Novina, 1931), 291-322.

71 "Po marmarošském procesu," Národní listy (5 March 1914), 2.

72 "Karpatští Rusové v Praze," České slovo (23 May 1919), 5.

${ }^{73}$ Memorandum To His Excellency, Woodrow Wilson, President of the United States of America, from the American National Council of Uhro-Rusins, October 1918. In Př́spěvek k ústavním dějinám Podkarpatské Rusi, Memorandum Amerických Rusínů, Zdeněk Peška, ed. AÚ TGM Fond TGM-R, carton 403, document no. 1255/31.
} 
Republic, they will constitute a fully autonomous state." ${ }^{74}$ On the basis of this promise the Rusyn-American council agreed to the union in November 1918, but Masaryk requested they hold a "plebiscite" among the American Greek Catholic parishes to give the agreement added weight at the Paris Peace Conference. ${ }^{75}$ The results showed $62 \%$ of voters supported union with Czechoslovakia, while $28 \%$ supported joining a future Ukrainian state. ${ }^{76}$ Zhatkovych arrived in Ruthenia in March 1919 to negotiate with the local Rusyn councils, and they passed a resolution approving union with Czechoslovakia. ${ }^{77}$ The resolution was then presented to the Allied powers at the Paris Peace Conference and in May 1919 the Supreme Council formally agreed to the plan.

The decision of the Allied powers at the Peace Conference to include Ruthenia within the boundaries of the new state of Czechoslovakia came as a surprise to many Czechs, as the region had not been among the territories first considered by leaders Masaryk and Beneš. ${ }^{78}$ Initially there were suggestions in Czech intellectual circles that Ruthenia might remain part of the republic for only a short period of time until the political borders to the east of the republic were clearer. For instance, in 1920 Professor Karel Kadlec claimed that the "affiliation of Ruthenia with our republic is only temporary," and he expressed hope that "our public will realize we are keeping it as a foreign deposit which someday we must give up."79 If this separation were to eventually occur, Václav Drahný, a Czech agriculture official who went to Ruthenia, felt that their work in the territory would be for a greater Slavic cause: "If we should one day give it into the hands of friends, either Ukrainians or Russians, it must be in such a condition that we can be proud of our work done for a brotherly Slavic nation." 80

When it was officially announced on 8 May 1919 at the Paris Peace Conference that Carpathian Ruthenia would join Czechoslovakia, an unexpected opportunity for Czechs to show

\footnotetext{
${ }^{74}$ Gregory Zhatkovych attributed these words to T.G. Masaryk in: Gregory Zhatkovych, Expose Dr. G.I. Žatkoviča, byvšeho gubernatora podkarpatskoj rusi, o podkarpatskoj rusi (Homestead, Pennsylvania: Amerikansky russky viestnik, 1921), 5.

75 T.G. Masaryk, personal letter to Gregory Zhatkovych, 19 November 1918. AÚ TGM Fond TGM-R, carton 400; see also Paul Robert Magocsi, "The Ruthenian Decision to Unite with Czechoslovakia," Slavic Review (June 1975, vol. 34, no. 2), 374.

${ }^{76}$ Krofta, Carpathian Ruthenia and the Czechoslovak Republic, 23.

${ }^{77}$ Vincent Shandor, Carpatho-Ukraine in the Twentieth Century (Cambridge, Mass.: Harvard University Press, 1997), 8 .

${ }^{78}$ Edvard Beneš, Podkarpatsko a jeho vztah k Československu (Prague: Společnost přátel Podkarpatské Rusi, 1996), 20.

${ }^{79}$ Karel Kadlec, Podkarpatská Rus (Prague: Nákladem státovědecké společnosti, 1920), 26.

${ }^{80}$ Václav Drahný and František Drahný, Podkarpatská Rus: její př́rodní a zemédělské poměry (Prague: Ministerstvo zemědělství, 1921), 3.
} 
leadership and solidarity towards a less fortunate Slavic nation emerged. The Rusyn people had been among the poorest in the Austro-Hungarian Empire, and Czechs envisaged a paternal relationship where they would be the teachers and role models who could help raise the Rusyn people out of their humble conditions. When a Rusyn delegation arrived in Prague a few weeks after the announcement, the Czech press greeted them with fanfare; Kramář's newspaper Národní listy declared that "Prague is their mother city, like it is for us, and we have only one wish, that on our soil they will feel at home, like they would in their own land." 81 National Socialist gazette České slovo welcomed the delegation and claimed that "what the Carpathian Rusyns could not achieve under Hungarian tyranny, they can achieve now. All of them hope to feel secure in the republic of Czechoslovakia, where they will live and be able to feel at home." 82

During the first months after the announcement Czech officials and journalists expressed confidence that Rusyns were waiting patiently for Czech leadership to guide them towards a better future. Václav Drahný claimed that Rusyns were "awaiting our help and establishment of order," while they hoped that "Czechs, as a brotherly nation, will help improve the cultural situation and welfare of the people and bring them to the same level as the Czech nation." 83 Prague gazette České slovo exclaimed that this "good and sincere Slavic nation” was now "waiting for Czech guidance in social reforms," 84 while Brno's Lidové noviny claimed that "if the decision-makers of the Czechoslovak Republic give them enough attention, the inhabitants of Ruthenia will become the most devoted citizens of the Czechoslovak republic." 85 In his new role as Governor of Ruthenia, Gregory Zhatkovych thanked President T.G. Masaryk for liberating the Rusyn people and confirmed their confidence in Prague's leadership: "The Carpathian Rusyns know that they are deeply indebted to you for their present freedom and they are waiting with joy, trust and honesty for your complete administration of justice." ${ }^{, 86}$

For Czechs who believed in the ideals of Pan-Slavism, accepting the task of nurturing and developing the Rusyn people was a Slavic duty. In 1921 the Olomouc gazette Našinec conveyed the sense of Slavic responsibility Czechs had assumed for the Rusyn nation: "Relations

\footnotetext{
81 “Karpatští Rusové v Praze," Národní listy (22 May 1919, Evening Edition), 1.

82 "Karpatští Rusové v Praze," České slovo (23 May 1919), 5.

${ }^{83}$ Drahný and Drahný, Podkarpatská Rus: její prírodní a zemědělské poměry, 105.

84 "Podkarpatská Rus," České slovo (14 October 1919), 1.

85 “Naléhavé otázky Podkarpatské Rusi," Lidové noviny (25 February 1921), 1.

86 “Blahopřání Gubernátora Dra Žatkoviče Presidentovi Republiky,” Národní politika (1 June 1920), 1.
} 
with Subcarpathian Ruthenia are, it's possible to say, a test of our Slavic reciprocity. [...] The Rusyn people need our help, they have entrusted to us their fate." ${ }^{87}$ The first Czech vicegovernor of Ruthenia, Petr Ehrenfeld, claimed that "a Rusyn always looks to his Czech brother, who with love stands by his side," 88 while Lidové noviny believed that the Czech nation "must approach these Slavs and learn to know and to love this nation which has no history." 89 In a similar vein, President Masaryk's adviser Jaromír Nečas claimed that Ruthenia would be "a bridge between the western and eastern Slavs and a stepping stone for the solution to the question of Slavic solidarity." 90

Some Czech officials in Ruthenia expressed hopes that administering the territory could give the Czech(oslovak) nation an opportunity to show leadership towards the wider Slavic world. Writing in 1921, The Presidium Ministerial Council for Ruthenia [Presidiu ministerské rady pro Podkarpatskou Rus] declared that future generations would remember their actions:

Historians will judge how successful the Czechoslovak nation has been in their cultural mission, if they lived up to their reputation as a selfless pioneer of Slavic interests, if they showed an appreciation of their cultural and Slavic mission. This will be asked mainly by Russian historians, and also by all other Slavic historians.

The Ministerial Council also claimed that the "success or failure" of the Czech "cultural mission" [kulturní poslání] for Ruthenia would "determine the prestige of Czechoslovakia in slavdom." $" 91$

Many Czech journalists also suggested that the union with Ruthenia symbolized the Czech nation's new strength and prominence within the Slavic world. Czech-American journal Bohemian Review expressed confidence in the Czech nation as Slavic leaders, claiming that Rusyns "no longer looked to Moscow but to Prague as the spiritual capital of the Slav race" and that this reflected a "flattering recognition of the wise, brave and manly course of the Czechoslovaks during the war." ${ }^{92}$ Lidové noviny proclaimed that in Ruthenia "a great task awaits

\footnotetext{
87 “K otázce Guvernerské na Podkarpatské Rusi," Našinec (30 April 1921), 1.

88 “Dva roky svobody Podkarpatské Rusi," Československá republika (7 December 1920), 1.

89 “Guvernér Žatkovič o Podkarpatské Rusi,” Lidové noviny (15 June 1920), 1.

90 Jaromír Nečas, "Podkarpatšti Rusíni v naši republice,” Brazda (January 1920), 18.

${ }^{91}$ Memorandum a zřizení poradního sboru při prezidiu ministerské rady pro Podkarpatskou Rus, 1921. AKPR Fond PR, carton 3, item PR392, inventory number 234.

92 “Carpathian Russians and the Czechoslovaks,” Bohemian Review (May 1918, vol. 2, no. 5.), 72.
} 
us, organizing the great future of Slavdom," 93 while for Národní listy journalist Rostislav Korčák Ruthenia confirmed the central role of the Czech nation in the Neo-Slav movement: "The idea of pan-Slavic cooperation, this idea was minted purely by the Czechs." 94 The media also spoke of the new strength of the Czech nation in European diplomacy, with Prague magazine Zlatá Praha optimistically claiming that "Czechs will be the nucleus of Central Europe,"95 while Lidové noviny encouraged Czechs to become "the intermediaries of Slavdom with the west."96

For Kramár and other supporters of the Neo-Slav movement, the union with Rusyns represented a potential stepping stone towards establishing a future Pan-Slav state or broader political alliance. In May 1919 Kramářr's organ Národní listy described the Rusyns as "the first Slavs who wish to live with a brother nation in a unified state" and that they understood the need for "reciprocity and a federal association of Slavic states."97 Národní listy also articulated Kramářr's desire to help crush the Bolshevik revolution in Russia, claiming that Rusyns "see in us the future organizers of a democratic federal Russian republic." ${ }^{98}$ Kramář's belief that the Czech nation could play a leadership role in helping to establish a democratic Russian state rested on the political and military significance of the Czech legions which were occupying strategic parts of Russia at that time. Kramár also stressed that the addition of Ruthenia to the republic could not be considered a hostile act against fellow Slavs, for he rejected the notion that "a Slavic nation would want to expand at the expense of another Slavic nation through political, cultural or economic means." ${ }^{99}$ His organ Národní listy claimed that "the joining of Subcarpathian Ruthenia to our territory is not an imperialistic act, as it would be by any other regime, but is an act of Slavic love.",100

As the poor living conditions and low cultural level of Rusyns became more widely known, the Prague government drew a sharp contrast between the brotherly friendship offered by their administration and the "neglect" of the former Hungarian regime. When describing the challenges Czechoslovakia faced in the territory, Prime Minister Antonín Švehla explained that

\footnotetext{
93 "Po pěti letech," Lidové noviny (19 October, 1919), 2.

94 Rostislav Korčák, “Karpatoruský problém,” Národní listy (22 May 1919), 1.

95 Josef Holeček, "U Skrejšovského," Zlatá Praha (27 October 1920), 391.

96 "Po pěti letech," Lidové noviny (19 October, 1919), 2.

${ }^{97}$ Rostislav Korčák, "Karpatoruský problém,” Národní listy (22 May 1919), 1.

${ }^{98}$ Rostislav Korčák, “Karpatoruský problém,” Národní listy (22 May 1919), 1.

${ }^{99}$ Karel Kramáŕ, quoted in: Jaromír Nečas, Prosím za jeden slovanský národ (Brno: Rolnické tiskárny, 1918$), 31$.

${ }^{100}$ Rostislav Korčák, “Karpatoruský problém," Národní listy, (22 May 1919), 1.
} 
"the conditions in Ruthenia today are the result of a collision between two regimes, the old feudal regime of Hungary" and "the new, democratic one," while condemning the Hungarian "state apparatus, schools, churches, and organization of the economy" which had sought "the destruction of the Rusyn nation." ${ }^{101}$ Vice-governor Ehrenfeld also contrasted the two systems of rule by the Czechs and the Hungarians, claiming that the Rusyn peasants liked to use the expression "a Hungarian was a master, a Czech is a brother."102 Although Rusyns composed two-thirds of the population in Ruthenia, the Hungarian and Jewish minorities held a significant cultural and economic advantage at the outset of the republic. ${ }^{103}$ Václav Drahný expressed the government's intention to level the playing field for Rusyns in Ruthenia, despite the interference of the non-Slav minorities: "As a friendly people, we must advise them in all matters so that we gain their trust, which the Hungarians, Magyarones and Jews intend to prevent at every step."104

Czech generosity was perhaps best expressed through the humanitarian work undertaken by the Czechoslovak Red Cross, headed by President Masaryk's daughter Alice. With many Rusyns malnourished and diseases such as typhoid rampant, there was an urgent need to provide food and medical care. A Czech official surveying the needs of the peasants in Ruthenia's Mizhhiria/Volové region noted that "here there is hunger in the truest sense of the word," which had led to "more deaths here in the month of January than during the entire year of 1915." This official believed that the only way to reduce the number of deaths from hunger in the region would be to provide "a monthly allocation of 15 to 20 wagonloads of corn or oatmeal and potatoes."

Food shortages were particularly acute during the winter months, and the Red Cross organized donation campaigns encouraging Czechs to give money, food and supplies for their Slavic brothers. ${ }^{106}$ Donation drives such as this announcement in 1920 called on Czechoslovaks to help a less fortunate region of the republic:

\footnotetext{
101 “Min predseda Švehla o Podkarpatskej Rusi,” Slovenský východ (2 February 1923), 1.

${ }^{102}$ Petr Ehrenfeld, "Iak rozvynuty Ches'ko-Rus'ku spivpratsiu," Iuvyleinyi al'manakh: Soiuzu Pidkarpats'kykh Rus'kykh studentiv u Prazi (Prague: 1931), 29.

${ }^{103}$ Census data on the Ruthenian ethnic groups in 1910, 1921 and 1930 is provided in: Macartney, Hungary and Her Successors, 203.

${ }^{104}$ Drahný and Drahný, Podkarpatská Rus: jeji př́rodní a zemédělské poměry, 107.

105 Županskému úřadu ve Volovoje, Regional administrative office report, 9 March 1920. AÚ TGM Fond TGM-R, carton 400.

${ }^{106}$ Alois Hora, "Dvě hvězdy," Lidové noviny (30 September 1921), 11.
} 
Tough and unbearable is the fate of this nation: at first neglected in health care and culture by a foreign nation, today it is oppressed by disease, hunger and poverty. They need underwear, clothing, food and medicine. [...] We call upon Czechoslovaks to show that they have good, honest hearts and feel a sense of national and human solidarity! ${ }^{107}$

By 1921 the Red Cross was spending 750,000 Czechoslovak crowns a week on aid programs in Ruthenia. ${ }^{108}$ Red Cross volunteers also collected donations of books and educational items for Rusyn school children; in 1921 Czech author Alois Hora encouraged the public to contribute money and school supplies for Rusyn children. He called on them to support Czech teachers in Ruthenia "in their work for the Carpatho-Rusyn people, for the Rusyn nation, for the state and for the Slavic idea." 109

The efforts of the Red Cross to combat poverty among Rusyns appeared in the Czech media and Prague government speeches as examples of Slavic love and caring. Prague gazette Ceskoslovenská republika considered the work of the Red Cross to be in the name of "human, Slavic and national love" and a task which required both "love and responsibility," Czechoslovak Legion newspaper Bratrství declared that the Red Cross workers toiled "for a better future for Slavdom, for the flowering of Slavic ideas." ${ }^{\prime 111}$ In 1923 Prime Minister Antonín Švehla contrasted the progress of the Red Cross with the neglect of the former Hungarian administration. He claimed that in Ruthenia "the government is endeavouring to improve the health of its citizens" while under the Hungarian regime "the inhabitants lacked even the most primitive medical protection and hygiene." Švehla expressed pride in the fact that "in Ruthenia five public hospitals are operating, plus two mobile field hospitals of the Czechoslovak Red Cross" and that due to these efforts "there is no danger from epidemic diseases such as typhoid fever and small pox." ${ }^{, 12}$ Minister of Public Works Alois Tučný also praised the progress of the Red Cross as an example of the paternal relationship between the Rusyns and the Prague government: "The actions of the Red Cross have achieved great success in social as well as

\footnotetext{
107 “Pomozte Podkarpatské Rusi!" Věstník obecní hlavního města Prahy (26 March 1920), 84.

108 "Komunisté a Podkarpatská Rus," Čas (9 December 1921). ANM Fond Starý , carton 1.

${ }^{109}$ Alois Hora, "Dvě hvězdy," Lidové noviny (30 September 1921), 11.

110 "Dílo lásky a zodpovědnosti," Československá republika (1 March 1923), 5.

111 "Nejbližší úkol slovanské politiky," Bratrství (8 March 1923), 182.

112 “Min. predseda Švehla o Podkarpatskej Rusi,” Slovenský východ (2 February 1923), 2.
} 
cultural and political fields. The Rusyn nation sees that in the Czechoslovak government it has a loving father." ${ }^{113}$ Rusyns could thus be both Slavic brothers and children in Czech eyes.

Czech officials and authors also sought to depict the work of Czech administrators in Ruthenia as an act of Slavic kindness. Vice-governor Ehrenfeld claimed that after several years of progress "the Rusyn nation in Ruthenia has found that the Czech nation are their brothers, who will help them with all their strength in the fields of culture and economy." ${ }^{114}$ Writing about the education system in Ruthenia in 1924, academic Dr. Karel Matoušek proclaimed that "Rusyn schools, established and organized by Czechs, are the most beautiful evidence of genuine Czech care for the uplifting of Slavic Ruthenia, and it will bear good fruit."115 Matoušek also focused on the skills of Czech officials as Slavic leaders, claiming that "the burden of organizing this completely neglected territory remains on the Czechs" who had "shown excellent organizational talent and true Slavism."116 The ruling Czech Agrarian Party newspaper Venkov summarized the selfless acts of Czech officials who agreed to go and work in Ruthenia in 1921: "There are people in the world who give for others - those who go to work in Ruthenia are unusually giving.", 117

Czech author Josef Linek portrayed Czech officials in Ruthenia as Slavic heroes who showed that the Czech nation were "western" Slavs. He praised their tireless effort for Rusyns in 1922: "Their work elevates these people. The reward is that they can feel pride in working for a piteous Slavic nation. We hope that this is not forgotten in future." ${ }^{118}$ Linek also declared that their efforts in Ruthenia showed that the Czech nation were "Slavs of the west, a nation of heroes, soldiers and workers" who were striving to "improve the land of the Carpathians." $119 \mathrm{He}$ called the Czech officials in Ruthenia "a rock of Czech strength and ability for a higher cause" who were building a "new, better future for the Rusyn nation." ${ }^{120}$ Linek summarized Czech

\footnotetext{
113 “Minister Tučný o svojej ceste na Podk. Rusi,” Slovenský východ (30 May 1922), 1.

114 Československá republika (19 April 1923), 3.

115 Karel Matoušek, Podkarpatská Rus (Prague: České grafické unie, 1924), 130.

${ }^{116}$ Matoušek, Podkarpatská Rus, 206.

117 “Český úředník na Podkarpatské Rusi,” Venkov (4 March 1924). ANM Fond Starý, carton 1.

118 Josef Linek, Podkarpatská Rus (Třebechovice pod Orebem: Josef Jarkovský, 1922), 39.

${ }^{119}$ Linek, Podkarpatská Rus, 47.

${ }^{120}$ Linek, Podkarpatská Rus, 47.
} 
efforts in Ruthenia as selfless acts of kindness which were "for one cause: to help a brotherly nation.",121

In addition to proclaiming the role of Czechs as Slavic leaders, the Czech press trumpeted foreign praise of their aid work in Ruthenia and the "western" Czech character which placed them above other Slav nations. In 1919 Lidové noviny suggested that Swiss bankers recognized Czechs as "the only Slavic nation with West European methods of commerce, finance and technical knowledge," and that such capabilities would allow Czechs to guide other Slavs by "showing the path towards modern manufacturing and commerce in the east." 22 Paris gazette Le Temps provided further confirmation in 1923 that Czech leadership in Ruthenia showed they were truly "western” Slavs. The translated text appeared in Prague newspaper Československá republika, ensuring that Czech readers could appreciate this praise of their nation. Le Temps claimed that Czech administrators were succeeding against the odds given the complete lack of development in Ruthenia:

When the Czechs arrived in Subcarpathian Ruthenia they found typhus, smallpox, degeneration, 90\% illiteracy and physical and moral misery. You can only praise the efforts of the Czechs and specifically the Czechoslovak Red Cross for improving the quality of the lives of the peasants in the Carpathians. ${ }^{123}$

Le Temps also reminded the Czech nation of their unique status as "western" Slavs: "Neither in Uzhhorod nor in Prague should Czechs forget that their unique position in Europe depends on this, that they are the most western of all the Slavs, perhaps even the only truly western Slavs." 124 In response to this praise, Československá republika commented that Le Temps had "correctly outlined the program and goals of the Czechs in Subcarpathian Ruthenia."125

Praise for the Prague government's progress in Ruthenia came not only from dependable allies such as France but also from their former rulers in Austria. In 1921 Vienna newspaper Neues Wiener Tagblatt lauded the efforts of Czech officials to improve the quality of life in the

\footnotetext{
${ }^{121}$ Linek, Podkarpatská Rus, 6.

122 "Po pěti letech," Lidové noviny (19 October, 1919), 2.

123 “Z Podkarpatské Rusi: Podkarpatská Rus a Čsl. politika v zrcadle Pařížského 'Tempsu'," Československá republika (29 September, 1923), 3.

124 “Z Podkarpatské Rusi: Podkarpatská Rus a Čsl. politika v zrcadle Pařížského 'Tempsu',” Československá republika (29 September, 1923), 3.

125 “Z Podkarpatské Rusi: Podkarpatská Rus a Čsl. politika v zrcadle Pařížského 'Tempsu'," Československá republika (29 September, 1923), 3.
} 
Rusyn villages despite the resistance of the ungrateful Rusyn peasants. Československá republika translated the article for the benefit of its Czech readership:

When the government sent doctors to Subcarpathian Ruthenia in order to fight the epidemic diseases there, the people fled from them, even those who were ill. In all the larger villages state schools were established, but it was necessary to lure the students. Czech women, teachers and professors go from village to village, holding puppet shows in order to entice the inhabitants to attend them. ${ }^{126}$

Neues Wiener Tagblatt portrayed Czechs as true Slavic leaders: rational, educated Slavs bringing enlightenment to uncivilized and ignorant Slavs. Československá republika agreed that the Vienna newspaper had accurately represented the conditions in Ruthenia. ${ }^{127}$

In the interests of further tightening the Slavic links that bound Czechs, Slovaks and Rusyns together in the new state, Czech historian Jiří Král promoted the idea that Ruthenia had formed part of the ninth-century Great Moravian Empire. The historical Slavic kingdom provided a claim to the Slovak and Rusyn lands which predated Hungarian territorial claims. In 1923 Král claimed that all of the western half of Ruthenia had belonged to Great Moravia, ${ }^{128}$ and pointed out the significance of supposedly Great Moravian archeological remains in the village of Horjany near Uzhhorod [today the south-eastern Uzhhorod suburb of Horiany]. ${ }^{129}$ Czech historian and journalist Florian Zapletal disagreed with Král's claim, ${ }^{130}$ and Czechoslovak Foreign Affairs minister Kamil Krofta would later refer to the "common belief" of Ruthenia's inclusion in Great Moravia as a "misconception.",131

The successful campaign to create the independent Czechoslovak Republic convinced some Czech intellectuals that they had become leaders in the Slavic world. After centuries living under Austrian rule, the Czech nation had come of age and was ready to be a significant player on the European stage. The unexpected addition of Ruthenia to the republic provided Czechs

\footnotetext{
126 “Bosna Československého státu," Československá republika (29 December 1921), 4.

127 “Bosna Československého státu," Československá republika (29 December 1921), 4.

128 Jiř́ Král, Osídlení Podkarpatská Rus (Prague: Rajhrad, 1923), 7; see also Jiří Král, Podkarpatská Rus (Prague: Unie, 1924), 74.

${ }^{129}$ Jiří Král and Antonín Svoboda, Turistický průvodce Podkarpatskou Rusí a Slovenskem východné od Košic (Mukacheve: Novotný a Bartošek, 1923), 18.

${ }^{130}$ Florian Zapletal, “Podkarpatská Rus částí Veliké Moravy?” Časopis vlasteneckého spolku musejního v Olomouci (1926 edition), 120.

${ }^{131}$ Kamil Krofta, “Čechoslováci a Podkarpatská Rus,“ in Podkarpatská Rus, Jaroslav Zatloukal, ed. (Bratislava: Klub prátel Podkarpatské Rusi, 1936), 19.
} 
with an opportunity to exercise these leadership ambitions; as a poor, backwards and neglected people, Rusyns needed immediate organizational help and material aid to improve their desperate conditions. The Czech outpouring of Slavic brotherhood which greeted Ruthenia's entry to the republic built on the legacy of the Neo-Slav movement and the values of Slavic reciprocity, yet despite these sentiments Rusyns would become paternal objects in an unequal relationship.

Many Czech officials went to work in Ruthenia with good intentions, believing that their efforts were for the improvement of the new state and fulfilled a sense of Slavic duty. The Prague government and Czech media contrasted their Slavic compassion for Rusyns with the neglect and mismanagement of the previous Hungarian regime. The Czechoslovak Red Cross worked tirelessly to provide food, clothing and medical care for the most destitute Rusyn peasants, and donation drives raised money and supplies for hospitals and schools. Kramář's Národní listy may have foreseen that some observers might consider Czech aspirations in Ruthenia to be a form of imperialism instead of "an act of Slavic love," but in the first years of the republic Czechs had unshakeable confidence in the righteousness of their help for these fellow Slavs. ${ }^{132}$ However, Rusyns would not necessarily reciprocate the view of Czechs as their benefactors.

${ }^{132}$ Rostislav Korčák, “Karpatoruský problém,” Národní listy, (22 May 1919), 1. 


\section{Chapter 2}

\section{From Euphoria to Disillusionment: Rusyn Responses to Czech Rule}

Most Rusyn intellectuals reacted with jubilation and gratitude towards their Czech liberators when Ruthenia joined Czechoslovakia in 1919. However, within just a few years of joining the republic their euphoria gave way to growing doubts about the intentions of the Czech administration. The political and cultural autonomy promised to Rusyns in the Treaty of Saint Germain and enshrined in the Czechoslovak constitution did not materialize, and repeated claims by the Prague government that full autonomy would be granted only when Rusyns were culturally and politically prepared added to the disillusionment. Rusyn intellectuals frequently echoed the sentiments of Slavic brotherhood expressed towards them by the Czech elite, but defending their own national interests soon took precedence. This chapter examines the gradual loss of trust towards the Czechoslovak government among the Rusyn elite and identifies the policy decisions which caused this shift.

Rusyn intellectuals were sharply divided into competing groups: Russophiles, Ukrainophiles and a smaller number of Rusyn particularists. The Prague government initially offered cultural and linguistic support for Ukrainophiles, leading Russophiles to become harsh critics of Czechoslovak government policies. All Rusyn factions worried about the risks posed by Czechization as the Czech-dominated administration of the territory became more entrenched. Concerns about Czechization took several forms: firstly in the regional administration, secondly in the school system, thirdly in the growing use of the Czech language in all areas of public life, and fourthly in the form of farmland colonization by Czechoslovak legionaries. After several years waiting for the promised political autonomy and independent parliament to materialize Russophiles became increasingly impatient, while Ukrainophiles were more willing to accept the situation as long as the Prague government continued giving them preferential treatment at the expense of Russophiles. Rusyn discontentment with Czechization would not develop into a united and coherent movement until the second half of the 1920s, but the Prague government's 
refusal to grant autonomy for Rusyns from the outset of the republic laid the foundation for the many political struggles which followed.

\section{Ukrainophiles, Russophiles and Rusynophiles in Czechoslovakia}

In 1919 most Rusyn intellectuals in Ruthenia and America joyously greeted the decision of the allied powers at the Paris Peace Conference to include their territory in Czechoslovakia. One of the first Rusyn reactions to the decision appeared in June 1919 in the debut issue of the newly-founded Uzhhorod publication Russkaia zemlia. In grand statements the authors, representing the new Carpatho-Rusyn Labour Party [Karpatorusskaia Trudovaia Partiia], expressed high hopes for their future with the Czechs and Slovaks in the new state:

Accession to Czechoslovakia has been accomplished, we will live in partnership with our Czechoslovak brothers. [...] We want to live together with Czechoslovaks, but to live our own independent national life. Additionally, we believe that our good Slavic brothers will not only help us in our cultural work, they will be glad to do so. ${ }^{1}$

Rusyn-American newspaper Amerikansky russky viestnik, published by the father of Gregory Zhatkovych, praised Beneš for his skill in bringing Ruthenia into the republic: "When we speak of our political success, we cannot overlook one of the strongest diplomats of the Czecho-Slovak republic, Dr. Edvard Beneš, who is now the foreign minister - and thank god - also ours."2

Rusyn intellectuals continued to celebrate the impending union with Czechoslovakia until the signing of the Treaty of Saint Germain made the act official in September 1919. Weeks before the treaty signing, Russkaia zemlia spoke of the opportunity Czechoslovakia offered to secure the freedom of the Rusyn people: "Carpathian Ruthenia has entered into the structure of the Czechoslovak republic. For a thousand years we sons of this Rusyn land groaned in Hungarian slavery, but in the end we have at last achieved freedom." ${ }^{3}$ Rusyn leaders also expressed feelings of Slavic solidarity and placed trust in their new partners in Czechoslovakia; writing on behalf of the Central Rusyn National Council [Tsentral'na Russka narodna rada] in 1920, Antonii Beskid claimed that the Rusyn people "believe deeply in the sincere feelings and

\footnotetext{
1 "Nashe prysoedynenie k Chekhoslovakiy," Russkaia zemlia (7 June 1919), 4.

2 "Naš poklon - Ministru Beneš," Amerikansky russky viestnik (11 September 1919), 1.

3 “Avtonomiia Karpatskoi Rusy!” Russkaia zemlia (21 August 1919), 1.
} 
Slavic reciprocity of the Czech and Rusyn nations."” The terms of the Treaty of Saint Germain which applied to the Czechoslovak-Rusyn agreement appeared in the pages of Russkaia zemlia on 18 October 1919 under the proud headline "Our Autonomy." The three treaty articles guaranteeing political and cultural autonomy were subsequently included in the Czechoslovak constitution which the national parliament adopted on 29 February $1920 .^{6}$

The transition to a Czechoslovak administration for Ruthenia began immediately after the signing of the treaty. French military leader General Edmond Hennocque held administrative responsibility for the territory until Czechoslovak government authority could be established, and he remained in control of the regional military. ${ }^{7}$ In November 1919 Hennocque signed the Generální statut [General Statute] which created a system of administration for Ruthenia and made the river Uzh the temporary border between the Rusyn territory and Slovakia. The Statute gave authorization for the Rusyn language to become the language of instruction in schools and in administrative capacities. ${ }^{8}$ The Czechoslovak Ministry of the Interior then appointed a Czech official, Dr. Jan Brejcha, as a temporary regional administrator for Ruthenia, and created a fivemember Rusyn directorate led by Rusyn-American leader Gregory Zhatkovych. ${ }^{9}$

Zhatkovych accepted the position as head of the directorate and set about preparing the territory for an election to a regional parliament and the establishment of full political autonomy as outlined in the treaty. ${ }^{10} \mathrm{He}$ felt the Rusyn directorate did not have enough power to direct policies for Ruthenia and implement his plans for autonomy, so he resigned from his post in 1920. The Prague government reacted to this move by abolishing the directorate and appointing Zhatkovych as governor of Ruthenia in an attempt to maintain a useful working relationship with him. Zhatkovych agreed to take on the new position and continued to develop his plans for an autonomous parliament, but he soon faced growing resistance from Prague. Zhatkovych believed that the relationship between Czechoslovakia and Ruthenia was directly comparable to the

\footnotetext{
${ }^{4}$ Declaration signed by Antonii Beskid on behalf of the Central Rusyn National Council, 26 June 1920. AKPR Fond PR, carton 2 .

5 "Nasha avtonomiia," Russkaia zemlia (18 October 1919), 2.

${ }^{6}$ Ústavní listina Československé republiky, 121/1920, 29 February 1920.

${ }^{7}$ Ivan Pop, Podkarpatská Rus (Prague: Libri, 2005), 113.

8 “Avtonomnaia dyrektoriia," Russkaia zemlia (22 November 1919), 1.

9 “Organisace autonomního zř́zení v Přikarpatské Rusi," Našinec (16 December 1919), 1-2.

10 “Prezydent Zsatkovics Gergely," Russkaia zemlia (18 October 1919), 3.
} 
political system in the USA, where each individual state held the right to control its own internal affairs. $^{11}$

A dispute between Zhatkovych and the Prague government arose over the translation of the section of the Treaty of Saint Germain related to his powers. Paragraph 2, section 4 of the Czechoslovak constitution used the words "místní správa" [local administration] when describing the powers of the Ruthenian governor and its parliament, a phrase which Zhatkovych took to mean "internal affairs," or the right for Ruthenia to have self-government according to the American model. ${ }^{12}$ Czech newspaper Národní listy later suggested that Zhatkovych had been confused by the translation of the word "local" from the original French-language version of the Treaty of Saint Germain. The official Czech version of the treaty translated the French word "local” as "místnî" (which Národní listy considered to be correct) while Zhatkovych took "local" to mean "vnitřní" [interior], and considered this as the basis for his right to appoint local officials in Ruthenia. ${ }^{13}$ Národní listy saw the translation debate as "the first dispute, the first stage of Zhatkovych's struggle for political power in Subcarpathia, when he should have been undertaking more positive work." 14

Fears of potential instability in Ruthenia and the constant threat of Bolshevism and Hungarian revisionism made the Prague government reluctant to grant autonomy until conditions had significantly improved. ${ }^{15}$ Zhatkovych's relationship with President Masaryk, Beneš and Ehrenfeld grew steadily worse, and he gave his resignation in protest at the denial of Rusyn autonomy in February 1921. Masaryk was at first reluctant to accept the resignation since there were no other obvious Rusyn leaders in the Russophile, Rusynophile or Ukrainophile camps, but Zhatkovych could not be persuaded to reconsider and he left Ruthenia and returned to the USA in March 1921. ${ }^{16}$

Following Zhatkovych's departure, a struggle for dominance between Russophile and Ukrainophile orientations among the Rusyn intelligentsia intensified. The first Prime Minister of the new state of Czechoslovakia, Karel Kramař, became a strong supporter of a Russian

\footnotetext{
${ }^{11}$ Magocsi, The Shaping of a National Identity, 193.

12 Ústavní listina Československé republiky, 121/1920, 29 February 1920.

13 “Zápas o Podkarpatskou Rus,” Národní listy (21 May 1921), 2.

14 “Zápas o Podkarpatskou Rus,” Národní listy (21 May 1921), 2.

15 “K otázce guvernerské na Podkarpatské Rusi,” Našinec (30 April 1921), 1.

16 “Dr. Žatkovič o své demisi," Národní listy (20 May 1921), 2.
} 
orientation for Ruthenia’s Rusyns. Ukrainophile leader Avhustyn Voloshyn spoke out against the support of Kramář and his National Democratic Party for the Russophile movement, and accused him of violating Rusyn rights: "When a part of the Ukrainian nation freely joined with the Czech nation and asked their brothers for help, this leader of the National Democrats spoke against even the most fundamental rights for Rusyns." ${ }^{17}$ Kramář's defeat in the first Czechoslovak state elections in June 1919 came as a blow to the aspirations of Russophile Rusyns, who lost their only strong supporter in the Prague government. The new government led by Prime Minister Vlastimil Tusar had to make a choice as to which stream of the Rusyn intelligentsia it wished to support, and the Ukrainophile orientation was eventually chosen. ${ }^{18}$ Several factors played a role in this decision, foremost among them that Prague officials feared both the Russophile and smaller Rusynophile movements were in the hands of the Hungarian revisionists and actively working against Czechoslovak state interests.

The Russophile movement began under the leadership of two key figures, Antonii Beskid and Andrei Gagatko. Beskid headed the Central Rusyn National Council, and Gagatko founded the Carpatho-Rusyn Labour Party. The Russophiles opposed Gregory Zhatkovych's appointment as Ruthenian governor, and anti-Czechoslovak statements by Gagatko demanding "an autonomous Carpathian Ruthenia from Spiš to Sighet" brought increased government scrutiny of his activities. ${ }^{19}$ By late 1919 Vlastimil Tusar's administration had declared the Russophile movement to be a danger to the integrity of the state, claiming it to be "working for the detachment of Subcarpathian Ruthenia from the Czechoslovak Republic."20

The Rusynophile movement and its leader Ivan Kurtiak also received attention for its perceived Magyar leanings. Kurtiak led the Autonomous Agricultural Union [Avtonomnii zemledelcheskii soiuz], and developed close relations with the Hungarian government, receiving funding and support in the interests of revisionism. ${ }^{21}$ Most Rusynophiles were Greek Catholic priests in the city of Uzhhorod who had previously campaigned in the Rusyn national councils to have Ruthenia remain part of Hungary as the autonomous region of Rus'ka Kraina. Since the

\footnotetext{
${ }^{17}$ Avhustyn Voloshyn, Dvî polytychnî rozmovŷ (Uzhhorod: Rusyn, 1922), 8.

${ }^{18}$ Magocsi, The Shaping of a National Identity, 204.

19 "Mŷ trebuem," Russkaia zemlia (6 December 1919), 1.

${ }^{20}$ Otokar Růžička, Politické proudy v Přikarpatské Rusi, document of the Czechoslovak Ministry of Post and Telegraph (Prague: J. Růžička, 1919), 1. ANM Fond Brandejs, carton 2.

${ }^{21}$ Kurtiak's Hungarian revisionist activities are covered in detail in chapter 8.
} 
Prague government considered the movement to be a thinly-veiled attempt to disguise Magyarone revisionist sympathies, a Rusyn-particularist orientation for the territory was quickly discredited. The Czech daily Lidové noviny declared in 1920 that Magyarone Rusyn priests were "far more dangerous to our republic than true Hungarians." 22

With these two streams of Rusyn cultural orientation deemed to be dangerous for the republic, it became necessary by default to support the Ukrainophile Rusyn movement and its cultural organization Prosvita as a matter of state interest. In the early years of the republic three of the most prominent Ukrainophiles were Avhustyn Voloshyn and the brothers Mykhailo and Iulii Brashchaiko. As leader of the Rusyn Peasants' Party [Ruska khliborobska partiia] Voloshyn, a linguist from Uzhhorod who had formerly been Rusynophile, became the movement's leader. ${ }^{23}$

Ukrainophiles also received significant support from Jaromír Nečas, a Czech official who would later become a member of parliament representing the Social Democratic Workers' Party in Ruthenia [Sociálně demokratická strana dělnická na Podkarpatské Rusi]. In a book supporting the Ukrainophile orientation for a Czech audience in early 1919 he had claimed that "until now only the Ukrainians have been friendly to us and write about us with sympathy." ${ }^{24}$ Nečas had worked as an engineer in Ruthenia and Bukovina during the war, and in the first years of the Czechoslovak Republic he became a policy advisor on Rusyn affairs for President Masaryk, adding weight to the government's decision to support the Ukrainophile orientation. ${ }^{25}$

The response of the Russophile intelligentsia to the Prague government's show of political favouritism towards the Ukrainophile faction was angry and heated. They reacted by moving further from Prague's political orbit and became firm critics of Czech policy decisions, particularly the denial of the autonomy promised in the Treaty of Saint Germain. Government support for the Ukrainophiles also served to deepen the rift between the two rival factions, and Gagatko's party organ Russkaia zemlia expressed the threat posed by Ukrainophiles to their

\footnotetext{
22 “Z Podkarpatské Rusi,” Lidové noviny (23 March 1920), 3.

${ }^{23}$ Magocsi, The Shaping of a National Identity, 331-332.

${ }^{24}$ Jaromír Nečas, Uherská Rus a Česká žurnalistika: neuzavírejte kruh naších nepřátel (Uzhhorod: J. Skalák, 1919), 5.

${ }^{25}$ Nečas had also promoted his Ukrainophile sympathies in Ukrajina v prerodu Ruska: Východoevropská tragedie a Ukrajina, její vývoj a životni síly (Prague: Všeslovanská Expedice B. Havlíček, 1919).
} 
cultural life in strong terms: "Neither Slovakization, nor Czechization, nor Magyarization is as dangerous for our nation as Ukrainianization!"26

State censorship of articles in Russophile and Rusynophile newspapers became a regular occurrence by the end of 1919 , with the missing text replaced with the word "confiscated" [konfiskovano]. Articles in Russkaia zemlia faced such frequent cuts that the newspaper's editors may have considered having articles censored to be a valuable symbol of their anti-Czechoslovak government resistance. ${ }^{27}$ Russkaia zemlia addressed the issue of censorship in November 1921 in an article which was also partly censored: "The censors will not permit us to provide details of our intentions. We cannot write about what is causing us pain, what we are dissatisfied about, because they will confiscate all of it." ${ }^{, 28}$ Kurtiak's party organ Karpato-Russkii vîstnyk also received considerable attention from the censors. Ukrainophile publications which were outspoken on the autonomy issue, particularly the Social Democratic party's organ Vpered, faced less censorship which perhaps suggests favouritism by the Czech censors towards the Ukrainophile political parties.

Most Ukrainophiles remained loyal to the Prague government and its policies for Ruthenia despite uneasy relations with local Czech administrators. The Ukrainophile Social Democratic Party organ Vpered expressed their commitment to Czechoslovakia in 1922 despite these misgivings:

There are some [Czech] officials who have their noses in the air and place obstacles under the feet of our nation. Some officials and gendarmes have the old look of our former masters, they make fun of our poor nation. In spite of these rotten individuals we cannot throw mud at all the Czechs. [...] Our party believes in the goodwill of the Czechoslovak government, but we expect it to act sharply and without mercy against these Czech and Rusyn officials who hurt our nation and limit our rights with their behaviour. ${ }^{29}$

As long as the Prague government supported their orientation at the expense of the Russophiles, the Ukrainophiles were prepared to tolerate a certain level of Czech control over their affairs and kept their demands for autonomy in check.

\footnotetext{
26 "Natsional'naia smert'," Russkaia zemlia (17 August 1922), 1.

${ }^{27}$ For an example of an article which was completely censored except for its title, see: "Svoboda y avtonomiia," Russkaia zemlia (29 November 1919), 1.

28 "V zashchytu nashei svobodŷ!" Russkaia zemlia (24 November 1921), 1.

29 “Z Chekhamy, chy protyv Chekhov?” Vpered (13 August 1922), 2.
} 
After Zhatkovych's resignation, vice-governor Ehrenfeld took office while the position of Ruthenian governor remained vacant for the next two years. Ehrenfeld assumed most of the powers of the governorship and continued to implement policies for the territory issued by the government in Prague. The Russophile and Rusynophile factions considered him to be proUkrainophile, and Karpato-Russkii vîstnyk referred to Ehrenfeld as the "Ukrainophile vicegovernor" to show its dissatisfaction with his favouritism. ${ }^{30}$

Prominent Ukrainophiles continued to support the Prague government following Zhatkovych's departure. Voloshyn gave an interview in the newspaper Rusyn in 1923 where he proclaimed his continued loyalty to Prague: "In the interests of our people, I believe it is necessary to cooperate with our Czech brothers, to cooperate with the government." ${ }^{\prime 31}$ Fellow Ukrainophile Mykhailo Brashchaiko published a book titled Ches'ko-Rus'ki vzaemyny [CzechRusyn Relations] in 1923 where he argued in favour of the potential benefits the union with Czechoslovakia could have for Rusyns while downplaying the need for Prague to swiftly grant political autonomy:

We believe that Czechs and the Czech government understand our political concerns and will fulfill the terms of the peace treaty while enabling us to develop our political, cultural and economic affairs through our sincere and unshakeable friendship. It is not necessary for us to struggle to achieve our autonomy, for the Czechoslovak Republic will live up to its promise in the peace treaty. ${ }^{32}$

Brashchaiko's confident assurance that the Czechoslovak government would eventually fulfill the agreement on autonomy mirrored statements made by Czech Prime Minister Edvard Beneš at that time, ${ }^{33}$ but contrasted starkly with the increasingly anti-Czech writings among the Russophile intelligentsia and the Rusynophile autonomists.

Conflict among the three streams of the Rusyn intelligentsia presented the Czechoslovak government with complex problems when developing policy for the territory. Although Masaryk had hoped Zhatkovych could become a unifying leader for Rusyns, the Rusyn-American was unwilling to negotiate terms for autonomy and left a leadership vacuum following his departure.

\footnotetext{
30 “Peremîna," Karpato-Russkii vîstnyk (6 December 1923), 1.

${ }^{31}$ Avhustyn Voloshyn interview in: Rusyn (18 February 1923), 1.

${ }^{32}$ Mykhailo Brashchaiko, Ches'ko-Rus'ki vzaemyny (Uzhhorod: Rusyn, 1923), 24.

33 "Ministerský předseda o poměrech v Podkarpatské Rusi a na Slovensku," Československá republika (4 January 1922), 2.
} 
The government's decision to support Ukrainophiles turned the Russophile and Rusynophile leadership into anti-Czechoslovak campaigners, and divisions between the three camps would widen in the coming years.

\section{Rusyn Grievances}

Among the complaints Rusyn intellectuals directed at the Prague government, demands for the political autonomy promised in the Treaty of Saint Germain became a rallying point which Ukrainophiles, Russophiles and Rusynophiles could support. Following the resignation of Zhatkovych, the Ukrainophile intelligentsia who had backed him joined the Russophiles in speaking out more publically on the autonomy issue. The Rusyn Farmer's Party [Rus'koi khlîborobskoi partii] organ Rus'ka nyva, a Ukrainophile publication connected to Mykhailo Brashchaiko, quoted the demands Zhatkovych had made to the Prague government as a rallying cry for the Rusyn people: "A Czecho-Slovako-Rusyn federation! Full political cultural, economic and administrative national autonomy! This should now be our daily prayer until we are finally victorious." ${ }^{34}$ Kurtiak's Autonomous Agricultural Union also saw Zhatkovych's departure as a turning point in the Prague government's policies for the territory: "Until the departure of Zhatkovych you never spoke about the postponement of autonomy. [...] How long do you propose to postpone our autonomy? Until our nation has matured? For twenty, thirty years? ... We Rusyns will not be dissuaded." 35

The denial of autonomy became a regular grievance in Russophile and Rusynophile publications after 1921, with anti-Czech sentiments facing cuts by the state censors. To avoid the censors, authors sometimes used metaphors or employed creative means to get their point across to readers. A poem in Russophile Russkaia zemlia in 1921 expressed frustration at the Prague government's continued suppression of Rusyn rights:

Falcons today are not in their nests, they are bound with Czech ropes. Accursed sons have tied us up. [...] For your nation, for the Rusyn land, every Rusyn arise, get up! Those who are loyal, get to work, today is not the time to sleep!

\footnotetext{
34 “Gubernator Dr. Zhatkovych podiakovav," Rus'ka nyva (24 March 1921), 1.

35 "Protyv nashei samoupravŷ," Karpato-Russkii vîstnyk (21 August 1921), 1.
} 
Throw off the Czech shackles! For freedom we are ready to become like a living wall. ${ }^{36}$

The image of a "living wall" perhaps suggested the need to unite to repel the intrusion of Czech officials like foreign invaders. In a heavily censored article, Rusynophile Karpato-Russkii vîstnyk introduced the foreign word "anomaly" to their Rusyn readers with a series of sarcastic examples involving the issue of autonomy:

Anomaly is not a Russian word and is not easily understood, so I feel obliged to explain how it applies to us. [...] It is an anomaly that Subcarpathian Ruthenia still does not have an autonomous parliament, that elections to the parliament are postponed day after day, month after month and year after year. [...] It is an anomaly that in Subcarpathian Ruthenia, an autonomous part of the republic, such a small part of the administration is made up of local citizens. ${ }^{37}$

Such bitter feelings reached an audience further afield than just Rusyn intellectuals in Ruthenia, since many Rusyn newspapers had distribution and subscription arrangements in the United States. The Rusyn-Americans frequently wrote letters to the editors of the newspapers published in Ruthenia pledging their support for autonomy. ${ }^{38}$

Kurtiak's Autonomous Agricultural Union party remained one of the most outspoken critics of the Prague government's refusal to grant autonomy. In 1923 the party's organ KarpatoRusskii vîstnyk pointed out the absurdity of living in an autonomous territory which had no autonomy:

It is now four years since we joined the Czechoslovak Republic with a guarantee of the broadest possible autonomy, but building this autonomy still has not begun. It is the only territory in all of Europe which has such a form of autonomy, which is withheld against the will of the nation. We do not have representatives in the central parliament and do not have an autonomous parliament, which the peace treaty and the constitution of the republic called for. $^{39}$

It is worth noting that many Czech publications continued to refer to the "autonomous territory of Subcarpathian Ruthenia" long after serious negotiations over the autonomy issue had ended with Zhatkovych's resignation. For instance, a 1932 Czech school teacher's guide to Ruthenia

\footnotetext{
36 "Brat'iam Chekham,” Russkaia zemlia (24 November 1921), 2.

37 “Anomaliy," Karpato-Russkii vîstnyk (21 August 1921), 4.

38 This occurred prominently in Russkaia zemlia and Vpered.

39 "Nasha avtonomiia," Karpato-Russkii vîstnyk (27 May 1923), 1.
} 
would still erroneously claim that the territory "has its own parliament, which chooses its own President." $" 40$

With the right to elect a Ruthenian parliament denied and elections to the Czechoslovak national parliament postponed, Ukrainophiles also voiced their displeasure with the Prague government's stance on autonomy. Social Democrat newspaper Vpered expressed growing frustration with the political state of affairs that Prague had forced upon them:

What we long for: the rapid preparation of elections to the Prague parliament and to an autonomous parliament, because the nation can no longer tolerate this unconstitutional and uncontrollable regime under which it is kept. This is our last word. $^{41}$

By 1923 even Voloshyn's Rusyn Peasants' Party rebuked the Czechoslovak government: “They speak very often about autonomy, about the rights of Rusyns, but for autonomy they have not yet taken even one serious step." 42 The Rusyn Social Democratic Party had also toughened its position towards the Prague government by 1924: "In the coming year we will struggle to get an election not only to the national parliament, but also to an autonomous parliament, speed up land reforms, remove the threat of political denationalization from our schools, and try to end the chaos of Ruthenia's administration."43 Vpered even accused Czech officials of beginning to resemble their former Hungarian administrators: "In recent days the government has taken on the spirit of the old Hungarian regime. The officials have forgotten the laws - they have not actually forgotten them, but forgotten the democratic principles of the laws as they apply to our national rights." 44

The inability of the local Rusyn intelligentsia to find employment in the regional administration bred further resentment. The Prague government claimed there were not enough educated Rusyns to take the positions, but as the years passed and Rusyns began to graduate from institutions of higher education in Prague and other parts of Czechoslovakia there was little change in the status quo. Figures from the Uzhhorod administration show that among notaries working in 1921 there were 104 of Czech and Slovak nationality, 69 Rusyns and 65 Magyars. By

\footnotetext{
${ }^{40}$ Jaroslav Bartl, Podkarpatská Rus: Zeměpisný ilustrovaný přehled pro školu i soukromou potřebu (Velké Meziříčí: Aloise Šaška, 1932), 5.

41 "O nas, bez nas," Vpered (13 October 1922), 4.

42 "Mylŷi chytateliu!" Rusyn (1 January 1923), 1.

43 “1924," Vpered (11 January 1924), 1.

44 "Iak uriady vystupaiut' proty nas," Vpered (18 January 1924), 1.
} 
1935 the gap had actually widened, with 163 Czech notaries, 42 Rusyns and 29 Magyars. ${ }^{45}$ Highlevel positions such as the heads of the provincial administration remained in Czech hands. In 1922 the Ukrainophile publication Rus'ka nyva pointed out this disparity:

The peace conference gave us Rusyns independence, so that within the borders of the Czecho-Slovak republic we could freely develop our culture and our economy. In the eyes of all the world the Czechs are helping and supporting us. You hear this on the lips of all Czech officials, that they have come to help us and work for our nation. And what do we see in reality? That Rusyns everywhere are left on the sidelines. ${ }^{46}$

Social Democratic Party organ Vpered noted in 1922 that "for our people there is no place in the local administration," ${ }^{\prime 4}$ while in the same month the party condemned the Czech gendarme system in Ruthenia as akin to that of Czarist Russia and declared "we send our brother Czechs a warning that this cannot go on."48

Rusyns dealing with the local administration resented that most Czech officials in Ruthenia could not speak the Rusyn language. Czechoslovak government regulations required all Czech officials posted to Ruthenia to take courses in the Rusyn language, but in practice few of them developed any real ability in the language and expected Rusyns to understand them speaking in Czech. ${ }^{49}$ A letter to the editor of Vpered from a resident of the small eastern town of Rakhiv in 1921 complained that Czech officials there could not communicate in the Rusyn language: "In the regional courts and also in the administrative offices here they don't know even one word of Rusyn. [...] This calls for the autonomy of Subcarpathian Ruthenia! [...] We Rusyns want Rusyn officials, and a pure and free Rusyn nation in Subcarpathian Ruthenia."50

Ukrainophiles did not dismiss all Czechs as unwelcome outsiders, for they saw that some officials who lived in Ruthenia could be allies for their autonomy campaign. Social Democrat newspaper Vpered highlighted the benefits such enlightened Czechs could have for them: "It is a good sign for us that many Czech officials and Czech workers, who have lived among us for a

\footnotetext{
${ }^{45}$ Statistics from the Uzhhorod administration cited in: Macartney, Hungary and Her Successors, 225.

46 "Iak robliat' uriadnyky bratn'oho naroda," Rus'ka nyva (9 November 1922), 2.

47 "Dlia nashykh liudei nema mista v uriadakh,” Vpered (30 July 1922), 2.

48 "Reaktsiino-tsars'ki poriadky na Podkarpatskoi Rusy," Vpered (23 July 1922), 2.

${ }^{49}$ Rychlík and Rychlíková, Hospodářský, sociální, kulturní a politický vývoj Podkarpatské Rusi 1919-1939, 122.

${ }^{50}$ Unsigned letter to the editor from Rakhiv, Vpered (31 July 1921), 3.
} 
long time, understand our point of view and encourage us to struggle for our just cause." ${ }^{51}$ The author may have had Jaromír Nečas in mind, given his support for the Ukrainophiles and for increased autonomy for Rusyns. He published a book in the Rusyn language in 1924 to promote the idea that autonomy would be achieved more quickly if Russophiles and Ukrainophiles could set aside their differences. He suggested that the Prague government wanted to give autonomy to Rusyns, not Ukrainophiles or Russophiles who were always locked in disagreement: "Subcarpathian Ruthenia is autonomous, an inseparable part of the Czechoslovak Republic, and the republic will look forward to working with politicians who are neither Russian nor Ukrainian but only Carpatho-Rusyn." 52

The Czechoslovak elections of 1924 included candidates representing Ruthenia for the first time, and those who took office gained a larger platform for publically expressing their discontent with the political status of the territory. As a new Social Democrat MP, Nečas spoke of the friction between local Czech administrators and Rusyns in a speech to parliament in April 1924:

The Social Democratic Party of Ruthenia considers it to be its duty to appeal to the administrators of Ruthenia to keep in mind the Subcarpathian Rusyn people and their needs. [...] A prerequisite for the development of a peaceful and happy relationship in Subcarpathian Ruthenia is the need for friendly coexistence between Czech officials and the local population. ${ }^{53}$

Gagatko, also a newly elected MP, did not share such an outlook and flatly claimed that "trust between the Carpatho-Russian people and the [Czech] administration no longer exists."

The Prague government's handling of schools and education reforms would lead to further resentment among the Rusyn intelligentsia. Converting the former Hungarian-language schools into Rusyn-language schools was a slow process, since there were few qualified teachers who could teach in the Rusyn language. Galician and Russian immigrants filled some of the teaching gap, and Czechs also came to fill teaching positions. Czech publication Lidové noviny described the difficult task ahead in education reform in 1920:

\footnotetext{
51 “Shcho kazhe narod?” Vpered (13 October 1922), 4.

52 Jaromír Nečas, Persha promova tov. posla ynzh. Ia. Nechasa v spravakh Podkarpat. Rusy (Uzhhorod: SotsialDemokratichnoe partie Podkarp. Rusi, 1924). 32.

${ }^{53}$ Jaromír Nečas, Speech to the Czechoslovak national parliament, 9 April 1924, Session 259.

54 “Na okraj jubilejních slavností v Podkarpatské Rusi," České slovo (10 October 1924), 3.
} 
The low education level of the citizens (a large percentage are illiterate) requires immense effort. [...] They cannot open schools very quickly because there are still not enough teachers who know the local language. [...] In the colleges they still learn partly in Hungarian, also due to the lack of qualified teachers. ${ }^{55}$

The shortage of teachers remained a significant problem for the first few years of the republic, but a much more significant issue was determining which language should be taught in the schools, either literary Russian, literary Ukrainian, or the regional Rusyn dialects.

The issue of language instruction in schools heightened Russophile resentment of the Czechoslovak government's pro-Ukrainian stance. The government appointed a Czech official, Dr. Josef Pešek, as the chief inspector of schools in Ruthenia, a move which angered Russophiles who demanded direct control over their own schools as the constitution permitted. Russkaia zemlia fumed about the broken promises in 1921: "At the end of the war, our nation received 'freedom'. This promise included broad autonomy, first and foremost autonomy (the right to self-governance) of schools. But three years have already passed and our schools are still not ours. ${ }^{~} 56$ Pešek preferred Ukrainian as a language of instruction in the region's schools, drawing condemantion from Russkaia zemlia:

The Czechs came and they promised us complete autonomy over schools, but in place of this, instead of schools in the hands of Rusyns like the treaty stipulated, they sent us a school official, Mr. Pešek, who has already prepared an organizational plan for schools in Subcarpathian Ruthenia with non-Russian schools. ${ }^{57}$

Since the language of education represented the main battleground between the two competing orientations, Russophiles saw Pešek as a danger to their national existence.

The language question dominated Rusyn debate over schools, but by 1924 a further complaint against the Prague government's education policies had emerged: the risk posed by Czechization of the education system. The local administration founded Czech-language schools in Ruthenia for the children of Czech officials and gendarmes, often resulting in Czech schools in villages with just one or two Czech children. The number of Czech-language schools increased dramatically throughout the 1920s: In 1921 the territory had 22 Czech elementary

\footnotetext{
55 "Guvernér Žatkovič o Podkarpatské Rusi," Lidové noviny (15 June 1920), 1.

56 "Avtonomiia nashei shkolŷ," Russkaia zemlia (14 April 1921), 2.

57 "Nasha shkola - ne nasha," Russkaia zemlia (25 August 1922), 1.
} 
schools but by 1931 the number had grown to 158 , while in the same period Czech kindergartens increased from 4 to $43 .^{58}$

The Rusyn elite viewed these schools as an assimilationist threat, since Rusyn parents could decide to send their children to Czech-language schools to learn the state's main language and potentially receive a higher standard of education. Gagatko addressed the issue in 1924: “The Czechs are opening many schools where there are hardly any Czech children, and they think that Jewish children will fill up the school registers. We see this as a potential danger. [...] The Czechs should remember how they were oppressed in Austro-Hungary."59 A letter to the editor of Russkaia zemlia in the same year expressed doubts over Czech intentions for their schools: "The Czechs have signed a contract to open a Czech school in our village. [...] I pose this question: Where the population is $20 \%$ German, they would never allow the construction of German schools. Why should it be any different for us here?" 60 The issue of potential assimilation would grow larger in the Rusyn consciousness as more Czech schools appeared in villages throughout the territory.

A further significant grievance the Rusyn elite and the peasantry held towards the Prague government was colonization of farmland by Czechoslovak legionaries. The government put forward proposals in 1922 to offer land in Ruthenia to legionaries who had returned home following the war. The offer to war veterans served several purposes; firstly it provided a reward and employment for the returning legionaries. Secondly it placed trained soldiers into a region which was still potentially volatile. Thirdly it provided an example of modern Czech farming practices for the local Rusyns to learn from and potentially emulate. The first plots of land granted were predominantly in the south of the territory around the town of Bat'ovo/Bat'ovo, which according to Uzhhorod publication Rusyn, had some of the most productive farmland available anywhere in Ruthenia. ${ }^{61}$

The Prague government's plan to begin handing out parcels of quality farmland to Czech colonists aroused immediate resistance from the Rusyn intelligentsia, who considered the move to be inappropriate at a time when there were still many landless Rusyn peasants. Russophiles

\footnotetext{
${ }_{59}^{58}$ Statistics provided in: Macartney, Hungary and Her Successors, 233.

59 “Chekhyzatsiia," Russkaia zemlia (9 October 1924), 2.

60 "Vel. Bereznoe Cheshskaia shkola,” Russkaia zemlia (16 October 1924), 2.

61 “Kolonyzatsiia v Batiu," Rusyn (23 November 1923), 2.
} 
saw farmland colonization by legionaries as a threat to Rusyn interests, and a sharp reaction appeared in Russkaia zemlia in May 1922: "Rusyn farmers, smallholders and landless! Raise your voices in defence of your rights and vital interests and show the government that colonization of your land, even if it is by brother Czechs, would never be accepted, not even after our deaths. ${ }^{\circ 2}$ This proved to be an empty threat, as the Czechoslovak soldiers and their families met no resistance stronger than words following their migration to the region.

Ukrainophiles also reacted negatively to the proposed plan to settle Czechoslovak legionaries in Ruthenia. In October 1923 Rus'ka nyva ran a headline asking "Is There Any Land for Foreign Colonists? A Czech Voice for Colonization of Subcarpathian Ruthenia by Czechs.” The newspaper's use of the word "foreign" [chizhikh] to describe the Czech colonists contrasted strikingly with the rhetoric of Slavic "brotherhood" which had been so prominent just a few years earlier. Rus'ka nyva summarized their concerns about the Prague government's plans:

Colonization of the land of Ruthenia by Czechs is causing increasing discontent among the Rusyn nation. We believe that the planned colonization may lead to results which are not very pleasing to the administration. We are against the plan of our land being occupied by colonists instead of Rusyns, and we shall defend ourselves as strongly as possible. We want our land, until the last clod of earth, to be kept for our landless people and smallholders. We do not have any land to spare, just the opposite, there is not enough of God's ground available for us. ${ }^{63}$

Rus'ka nyva named Czech agriculture official Václav Drahný as a key promoter of the Czech colonization policies and found some common ground with his suggestions, pointing out that he had "reminded the Czech authorities not to take lands away from Rusyn villagers to give to Czech colonists," adding "this is what we wish to remind them as well." However, Rus'ka nyva also stressed that the government's plan could result in conflict with Rusyns eager to have their own land: "If they don't want any trouble to occur while taking the lands away, then let our voice be heard on this issue. [...] The Rusyn nation is waiting to receive land as if waiting for God's redemption.",64

The Social Democratic Party gave a stronger condemnation of farmland colonization in Vpered a few days later, under the blunt headline "The Colonization of Subcarpathian Ruthenia."

\footnotetext{
62 "Vozmozhno-ly!” Russkaia zemlia (11 May 1922), 1.

63 “Tsy ie u nas zemlî dlia chuzhykh kolonystov?” Rus'ka nyva (11 October 1923), 1.

64 “Tsy ie u nas zemlî dlia chuzhykh kolonystov?” Rus'ka nyva (11 October 1923), 1.
} 
Vpered claimed that Czech promises of land reform that would give the landless Rusyn peasants their own plots of farmland had come to nothing, and giving land in Ruthenia to Czech colonists was simply unacceptable:

For four years they have fooled our landless peasants and smallholders about land reform in the highlands. [...] Until the issue of land reform is dealt with by the officials there should be no talk of giving land to others. [...] The Prague chauvinists have two goals for the colonization process. They want to place legionaries among us and secondly they want to begin a process of denationalization in our region. ${ }^{65}$

The promised reforms to redistribute farmland on large former Hungarian-owned estates proved to be a slow and difficult process, which increased Rusyn concerns that legionaries would receive land before the Rusyn peasants.

The Rusyns of Ruthenia faced immense upheaval during the first five years in the Czechoslovak Republic. The promise of full political and cultural autonomy within Czechoslovakia produced outpourings of joy and immense expectations for a brighter future in partnership with their "brother Czechs." Faced with the monumental task of integrating the undeveloped territory, the Prague government promised to provide autonomy, but only when the Rusyn intelligentsia could handle the responsibilities of self-rule. Divisions among the Rusyn elite into competing Russophile, Ukrainophile and Rusynophile streams furthered Prague's perception that a land where Hungarian irredentism remained omnipresent could not be trusted to form their own parliament without creating chaos in the republic.

Rusyn Governor Gregory Zhatkovych failed to implement the Saint Germain treaty's promise of Rusyn autonomy and elections to a parliament, and by 1921 he had decided that the Czechoslovak government had no intention of granting these rights. Russophile and Rusynophile discontent with the government's support for the Ukrainophile linguistic and cultural orientation led to increasingly vocal protests about the denial of autonomy by leaders Gagatko and Kurtiak. Ukrainophiles also protested against the denial of autonomy after Zhatkovych's departure, but remained less critical of the Prague government's policies during the first years of the republic.

As delight at the prospect of autonomy among Rusyn intellectuals gave way to anger over the Prague government's broken promises, other unwelcome aspects of the new Czech

\footnotetext{
65 “Kolonyzatsiia Podk. Rusy,” Vpered (19 October 1923), 1.
} 
administration attracted criticism. The Treaty of Saint Germain had guaranteed that local officials would be selected from among the Rusyn population, when in practice Czechs dominated the system of administration for the territory. The Treaty had also assured Rusyns that they would have full control over their own schools and education system, yet Czech school officials such as Josef Pešek made the key policy decisions. Colonization of farmland by Czech legionaries was another policy decision which received heavy criticism from Rusyn intellectuals. When Rusyn political parties sought to complain publically about the denial of autonomy, their newspaper organs faced strict censorship on the pretext of defending Czechoslovak state interests.

A 1925 campaign poster for Gagatko's Russophile Carpatho-Rusyn Labour Party succinctly summarized Rusyn complaints about Czech rule by the mid-1920s (see Figure 2.1): in a drawing of a parade of Labour Party supporters, the banners held aloft displayed their main demands for the Czechoslovak government: "Long live the autonomy of Subcarpathian Ruthenia," "Give us Russian schools [Russkuiu shkolu]," "We demand a fair distribution of the border with Slovakia," "Give land to the small landholders." 66 The sequencing of the demands beginning from the front of the parade appears to suggest an informal ranking of their importance, with the autonomy question taking precedence as their first demand. Prague's refusal to reconsider the position of the frontier between Slovakia and Ruthenia as determined by the Paris Peace Conference angered Rusyn intellectuals who wished to be united with those they regarded as fellow Rusyns in north-eastern Slovakia.

In just five years many Rusyns had come to view Czechs as occupiers rather than as partners in their new state. The unfulfilled promise of political autonomy, Czechization of the administration and school system, and plans for farmland colonization by Czechoslovak legionaries all added to the loss of trust in Czech leadership. In spite of this, many Rusyn publications, particularly those of Ukrainophiles, continued to refer to the Czech nation as their "brother Czechs," indicating they still held out some hope that union with Czechoslovakia would eventually live up to the promise and opportunity they had looked forward to in 1919.

\footnotetext{
${ }^{66}$ Close-up image from a larger campaign poster inserted in Russkaia zemlia (31 October 1925).
} 
Figure 2.1 - "Carpatho-Rusyn Labour Party Campaign Poster," Russkaia Zemlia (1925) ${ }^{67}$

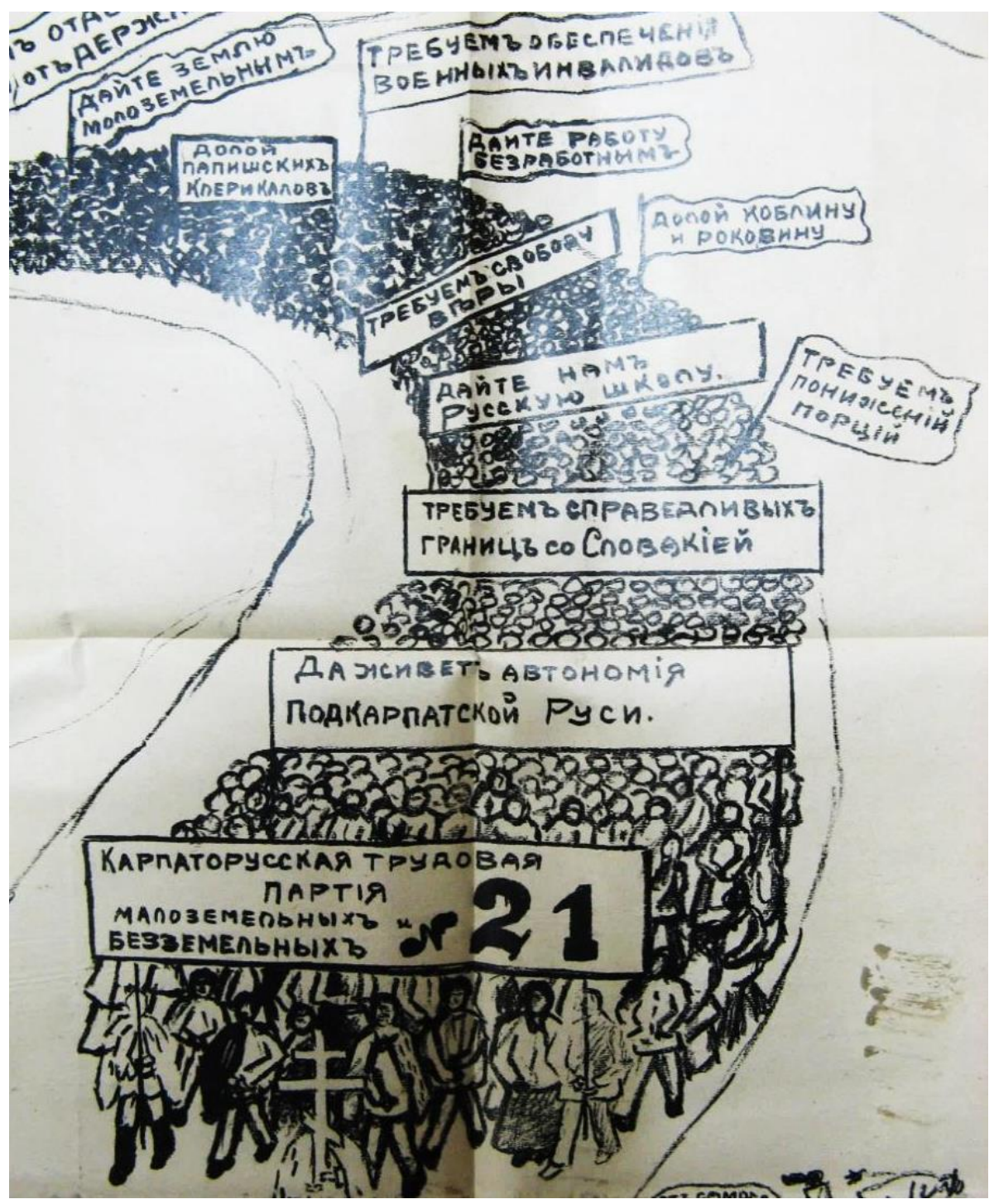

Parade banners from front to back:

"Carpatho-Rusyn Labour Party of Small Landholders and Landless"

"Long live the autonomy of Subcarpathian Ruthenia"

"We demand a fair distribution of the border with Slovakia"

"We demand a reduction in mortality rates"

"Give us Russian schools"

"Down with feudal obligations"

"We demand freedom in the mountains"

"Give jobs to the unemployed"

"Down with the Papal clerics"

"We demand social security for war invalids"

"Give land to the small landholders"

${ }^{67}$ Close-up image from a larger campaign poster inserted in Russkaia zemlia (31 October 1925). Photograph by the author. 


\section{Chapter 3}

\section{Constructing a Czech Civilizing Mission: Stereotyping Rusyns as a Primitive "Other"}

In the Czech imagination of the 1920s, Ruthenia formed a hazy image of a faraway territory where Czech efficiency and organizational skills struggled to overcome chaos and disorder. Czech elites perceived Rusyns as fellow Slavs, yet occupying a civilizational level far below that of the Czech nation. Czech media reports on Ruthenia in the early years of the republic often contained exaggerated claims of primitive conditions, while journalists focused their attention on the poverty and backwardness of the highland peasants. Such reporting cast the entire territory as helpless and in need of guidance. In this environment, the Czech media encouraged the public to view Ruthenia simultaneously as a savage region far removed from the civilized Bohemian lands and as a territory of Slavic brotherhood. Despite a common Slavic background, a Czech mentality of "us" and "them" gradually developed which objectified the Rusyn people as unCzech and even un-European. The territory of Ruthenia lay more than 600 kilometres to the east of the Bohemian lands, and although its Rusyn people were Christian their low level of cultural and economic development made it hard for Czechs to accept them as equal citizens in the new republic.

Drawing upon elements of Said's Orientalism and Todorova's Balkanism, the introductory chapter established a working definition of "Ruthenianism" to describe the CzechRusyn discourse in Czechoslovakia. Many of the attributes of Balkanism apply to the case of Czechoslovak Ruthenia, such as white and Christian inhabitants in a region with clear geographical boundaries, though the most important distinguishing difference for Ruthenianism is that it occurred between two Slavic nations living within the borders of a single republic as fellow citizens. Ruthenianism's other significant feature is that Czechs could consider Rusyns to be either Oriental or half-Oriental; Ruthenia appeared as a bridge to the East when Czechs wished to suggest Rusyns could learn and improve with Czech guidance, while it became purely Oriental when Czechs wished to highlight the cultural and civilizational differences between themselves and Rusyns while asserting claims to be viewed as part of the civilized West. 
The Orientalist view of Ruthenia as a colonial territory developed from an array of colonial stereotypes which portrayed Rusyns as a primitive nation which was unable to take care of itself. Czech descriptions of uncivilized behaviour by Rusyns relate closely to colonial stereotypes normally applied to European overseas colonies. Perceptions of Rusyns as childish, simpleminded, passive, lazy, drunken, unclean, feminine and primitive in behaviour appeared in the Czech media, academic books, popular literature and political speeches. Such stereotypes presented Rusyns as an "Other" who needed to be enlightened by Czech education and administrative order, affirming Czech resolve for what amounted to a mission civilisatrice for Rusyns. This chapter outlines the process of constructing and justifying the Czech civilizing mission on the basis of colonial stereotypes of Rusyns; it thus advances the argument for a discursive colonial relationship constructed in the Czech imagination. Expressing new selfconfidence in their role as leaders of Slavic peoples, the Czech elite considered bringing civilization to Rusyns to be a test of their credentials as a Western nation.

\section{"The People are Drowning in Ignorance": Colonial Stereotyping of Rusyns}

Before 1918 the Czech media had produced only a handful of newspaper articles about Rusyns and Ruthenia and publishers had printed few significant books for the general public about the subject. Following the announcement of Ruthenia's inclusion in the republic in May 1919, a new public appetite for information about the territory encouraged publishers to quickly fill the gap in knowledge. Many of the Czech articles and pamphlets which appeared in the first few months described rosy hopes for the future of the state's new Rusyn inhabitants, but contained few hard facts about Ruthenia since few journalists had visited the region. Writing in 1920, Czech author Vojtěch Lev described this blank space in the public consciousness:

When Carpathian Ruthenia was joined to our territory as an independent autonomous entity, our eyes turned to the east and yet we knew little, almost nothing about this land and this nation. Still today, after two years in the republic, we haven't learned any more about it during the short period since Carpathian Ruthenia joined us. ${ }^{1}$

\footnotetext{
${ }^{1}$ Vojtěch Lev, Brána na východ (Prague, Tiskový výbor Československé sociálně demokratické strany dělnické, 1920), 8-9.
} 
Vice-governor Ehrenfeld offered a similar impression of public awareness of the territory in 1921, suggesting Prague's inhabitants could easily believe that wild animals roamed through the towns:

Prague knows nothing about Carpathian-Russia. They have a vague idea that bears run around in the street. [...] I assure you, that on the boulevard of our capital city, Uzhhorod, may stroll perhaps chickens and goats, [...] old Jews and officers, but never bears, instead the only bear in the capital city sits in a cage in the Government park. ${ }^{2}$

Ehrenfeld's attempt to dispel such ignorance reflects how the Czech imagination had latched onto the image of Ruthenia as a savage land at the edge of the civilized world. Jaroslav Dostál would later make a similar observation in a tourist guidebook in 1936, reassuring potential Czech visitors that "it isn't dangerous here, bears and wolves avoid humans, and the people are good and honest - we encountered no evil here." 3

First-hand accounts of the conditions in Ruthenia began to appear in newspaper articles and pamphlets by the summer of 1920, written by adventurers who had visited the region. These publications often highlighted the extreme poverty and poor sanitary conditions they saw in Rusyn villages, perhaps because such details added drama that appealed to the imaginations of Czech readers. Czech scholar David Svoboda has described these early brochures about Ruthenia which appeared in the early 1920s:

Thin information brochures written by the first explorers were lacking exact details, however they excelled in their depiction of the devastation of the land, the pagan superstitions of the population and the ninety percent rate of illiteracy. 4

Dr. Karel Matoušek described the state of affairs in Ruthenia he had witnessed in the early 1920s: "The people are drowning in ignorance, superstition and alcohol, and therefore Subcarpathian Ruthenia represents the uncultured east of our republic."5

Czech media publications often mentioned the low level of public knowledge about Ruthenia with regret, proclaiming that Czechs must do more to reach out to their Slavic Rusyn

\footnotetext{
2 “Beim Gouverneur Zatkovich,” Prager Tagblatt (26 February 1921), 1.

3 Jaroslav Dostál, Podkarpatská Rus (Prague: Knižnice klubu československých turistů, 1936), 3.

${ }^{4}$ Svoboda, “Češi v zemi beze jména," 117.

${ }^{5}$ Matoušek, Podkarpatská Rus, 121.
} 
brothers. In 1923, Pardubice newspaper Východočeský republikán exclaimed "who among us was aware, who of us knew what Subcarpathian Ruthenia was?"6 The following year Plzeň's Nová doba claimed "there is much about [Ruthenia] which we Czechs don't know and this is to our great shame." 7 The void of general public knowledge would remain essentially unchanged into the 1930s; Olomouc newspaper Moravská orlice lamented the dismal level of Czech public awareness of Ruthenia in 1934:

On the subject of Subcarpathian Ruthenia very much is said, but very little is actually known. [...] Unfortunately, what our Czech public knows about Subcarpathian Ruthenia is wholly inadequate, they know it only from what they occasionally happen to randomly read in the newspapers. ${ }^{8}$

A Czech-language newspaper for Czechs living and working in Subcarpathian Ruthenia, Most mezi východem a západem [Bridge between East and West], suggested that media reports in the Czechs lands were still inaccurate in 1938: "it is indeed a shame that journalists, writers and editors provide such 'romantic misinformation' about Subcarpathian Ruthenia." ${ }^{9}$ Such accounts portrayed a sense of guilt for not reaching out and fully engaging with the Slavic Rusyns following their inclusion in the republic.

Suggestions that the Czech media provided a distorted view of Ruthenia in the interest of publishing sensational stories did not go unnoticed by Czech politicians. In January 1922 Prime Minister Beneš gave a speech denouncing the unfair stereotypes and prejudices about Rusyns which had been spread among the Czech public and government administration by inaccurate reports in the Czech media. Beneš admitted that he had had his own false assumptions about Ruthenia before his first visit to the territory:

I went to Ruthenia with expectations - because of the news that has been spread - that I would find extraordinarily hard local conditions there, I would say such as in Siberia or in Bosnia, with difficulties in every direction. I found out that these descriptions of the local conditions there are extraordinarily exaggerated. Subcarpathian Ruthenia is not known here [in the Bohemian lands], and is particularly unknown in Prague.

\footnotetext{
6 “Z Podkarpatské Rusi,” Východočeský republikán (5 August 1921), 2.

7 “Obrázky z Podkarpatské Rusi,” Nová doba (9 March 1924), 1.

8 “Podkarpatská Rus vykazuje ohromný pokrok," Moravská orlice (7 January 1934), 3.

9 “Jak se informují historické země o Podkarpatské Rusi,” Most mezi východem a západem (March 1938), 20.
} 
Beneš also addressed the media's reporting of Ruthenia and the impact it had on public opinion:

Our media who are covering this subject do not act appropriately, they exaggerate and do not see the political reality which is really there. [...] There has been an incorrect representation of Subcarpathian Ruthenia, above all in the circles of our journalists, and as a consequence of this among our public and to a large degree in our offices of administration. ${ }^{10}$

Beneš could see the potential danger to the unity of the Republic if Czechs could not accept Ruthenia as an integral part of the state, and the damage such misleading reporting could cause in relations with the Rusyn people.

Since initial Czech media coverage of Ruthenia often focused on the poverty of the poorest highland peasants, all of Ruthenia was stereotyped as uniformly backward and undeveloped. As a result Czech travellers who ventured to Ruthenia in search of exoticism often had their expectations dashed by the reality they saw; in a feuilleton for Národní politika journalist Olga Fastrová described her shock after arriving in Uzhhorod:

We saw something completely different from what we had expected. We drove along asphalt streets among modern houses and big city shop windows, and the men and women that we met were dressed in elegant fashions that wouldn't have been out of place in Paris or England.

She explained that the media had given her such false expectations: "We are told only about the terrible poverty and neglect in this eastern corner of the republic. [...] Few realize that the majority of Subcarpathian Ruthenia is not poor." 11 In this environment of media interest in the savage living conditions of the Rusyn highland peasants, stereotypes which portrayed Rusyns as inferior to Czechs flourished.

Among the colonial stereotypes prevalent in the early 1920s the image of Rusyns as childish became one of the most common. A Czech official who was among the first to arrive in Ruthenia declared that "it would be fatal if the first steps taken by our government failed the infinite and childishly sincere trust that the Rusyn people have for their 'brother Czechs'."12

\footnotetext{
10 “Ministerský Předseda o poměrech v Podkarpatské Rusi a na Slovensku," Československá republika (4 January 1922), 2.

11 Olga Fastrová, “Podkarpatský film,” Národní politika (27 July 1927), 1.

12 "Karpatoruský problém,” Národní listy (22 May, 1919), 1.
} 
Czech official Václav Drahný described Ruthenia as "a child that we must educate" because "this child is not at the same level that we are." He suggested that "we must carefully look after him because this baby is sick with a serious illness." 13 Another Czech official in Uzhhorod described the political immaturity of Rusyns in a mocking tone: "For the most part, the people there are politically backwards, even childish. Anyone who goes there and promises them something will have instant success!"14 By the early 1930s the image of Rusyns as childish had become common enough that Czech journalist and photographer Jaroslav Fabinger tried to refute the claim: "They are good-natured people, but unaware and distrustful. To call them big children, this is ignorant and false." 15 His words suggested that the stereotype was already familiar to his Czech readers.

Accounts of Rusyns as savage and uncivilized appeared in the first government reports and newspaper articles written by Czech officials. This example from 1919 focused on the primitive character of the Rusyn peasants:

We were convinced of the lowest level of the people there [in Ruthenia] by the following incident. Returning from one inspection tour we met a woman who was carrying two pigs under her arms. Not far from us the woman sat down alongside the road and suckled the pigs - from her own breasts. We were taken aback and asked a man walking nearby why the woman was doing such a thing and how would she be able to suckle her own children later. He replied quite nonchalantly that the pigs might have died of hunger on the trip and that would cost money, while children aren't worth anything. ${ }^{16}$

Such reports may have exaggerated the original events, but they are a reflection of the shock Czech officials experienced to find conditions which were very different from the Bohemian lands. Some officials described Ruthenia as like "the middle ages in our republic,"17 while a 1924 government report on health in Ruthenia referred to the lingering mentality of "medieval feudalism" among the peasants. ${ }^{18}$ Their descriptions of meetings with primitive and simpleminded peasants appeared in newspapers in the Bohemian lands, such as this front page

\footnotetext{
${ }^{13}$ Drahný and Drahný, Podkarpatská Rus: její přirodní a zemědělské poměry, 106.

14 “Problémy Podkarpatské Rusi: Dopis z Užhorodu - 2," Československá republika (22 August 1920), 1.

15 Jaroslav Fabinger, "Městské trhy na Podkarpatské Rusi," Pestrý tyden (8 July 1933), 12.

16 "Podkarpatská Rus, 1921," ANM Fond Starý, carton 1, folder 2, 3, as quoted in Magocsi, The Shaping of a National Identity, 201.

17 “Středověk v naší republice,” Večerník práva lidu (22 March 1920). ANM Fond Starý, carton 1.

${ }^{18}$ Dr. B. Albert, "Uvaha o sociálně-zdravotních poměrech v Podkarpatské Rusi se zřetelem na hospodářské, politické a národností otázky,” government report from November 1924. AÚ TGM Fond TGM-R, carton 403.
} 
story in Československá republika in 1920: "The people do not even know - if white flour is delivered to them - what to do with it. [...] from white flour they make at most a simple pancake, because the people, except for those in the towns, do not know how to make and bake bread. The pancakes they make then taste and look like mud." ${ }^{19}$ Such sensational newspaper accounts by Czech officials formed a large portion of the information which the general public received about Rusyns in the first years of the republic, contributing to the development of the impression that Ruthenia was a land of uncivilized customs and culture.

Other common stereotypes of Rusyns suggested they were of an inferior intellect, passive and lazy. The comments of an unnamed Czech official which appeared on the front page of Prague newspaper Národní listy in 1921 included multiple examples of such stereotypes. He began by describing the Rusyn cultural level, which he considered "very poor," and claimed that the cause "clearly lies with both the former Hungarian regime and with the natural character of the Rusyns. ${ }^{20}$ The official then outlined exactly why the Rusyn character had not progressed to an acceptable level:

The main cause of the low level of Rusyn development is their natural character. It is time that we tell the truth about this matter. On the whole, Rusyns are passive, lazy and unbelievably devoted to alcohol. Their passivity and laziness is most apparent in their approach to agriculture. Their cultivation of the fields is so superficial that you can't see the difference between the fields which are planted and those which are not planted. ${ }^{21}$

The Czech official then noted that ethnic Germans living in villages in Ruthenia used modern farming practices which their Rusyn neighbours were either too passive or lazy to adopt: "Despite seeing this example of efficiency, their Rusyn neighbours do not follow this example and merely insult them while envying the wealth which the Germans have." ${ }^{22}$ The official also found the Rusyn approach to agriculture primitive and willfully ignorant: "Except for the plow, a Rusyn is not aware of any other types of farming equipment, and what is more, they do not even

\footnotetext{
19 “Problémy Podkarpatské Rusi: Dopis z Užhorodu - 1," Československá republika (20 August 1920), 1.

20 “Z Podkarpatské Rusi,” Národní listy (22 June 1921), 1.

21 “Z Podkarpatské Rusi," Národní listy (22 June 1921), 1.

22 “Z Podkarpatské Rusi,” Národní listy (22 June 1921), 1.
} 
know how to use a plow as they should." Consequently, he concluded that "the agricultural sector, at least if it is located in the hands of the Rusyns, is absolutely primitive." 23

Frequent examples of Rusyns being described as unacceptably lazy occurred in Czech media publications in the early 1920s. When writing about the backwards farming practices of Rusyns, a Czech official suggested that although historical isolation had prevented development, "their laziness is also part of the reason." ${ }^{24}$ The lazy Rusyn lifestyle and its negative economic impact on the territory was forcefully presented by Richard Dušek, a Czech official working in Ruthenia:

Rusyns are lazy and don't work. All week a Rusyn doesn't work and doesn't take care of his financial needs. On Monday a Rusyn fasts, on Tuesday he is in the pub, on Wednesday he goes to town, on Thursday he sleeps, on Friday he fasts again, on Saturday he rests and on Sunday he gives thanks. ${ }^{25}$

The large number of public holidays in the Rusyn calendar and the slow pace of life in the villages conflicted with the desire of Czech officials to make rapid progress in the region's development. A further example suggested Rusyns were too lazy to take responsibility for their own living conditions: "Rusyns don't think about repairing their houses. In winter when there is no work to be done in the fields, a Rusyn does nothing and prefers to wait until his cottage is ready to fall down, and then he builds a new one."26

Czech descriptions of the lack of cleanliness and hygiene they found in Rusyn villages associated the Rusyn people with the stereotypical colonial image of dirty savages. The chief medical officer for Ruthenia, Dr. Josef Doškár, published a description of the state of health care in Ruthenia in 1921, drawing attention to the fact that Rusyns did not like to wash themselves:

Washing and bathing is not a common habit for Rusyns, they wash only on Sundays and don't bathe even in the height of summer, despite having crystal clear water all around them. Hygiene is half of staying healthy and the Rusyns lack hygiene, making typhus more widespread. ${ }^{27}$

\footnotetext{
23 “Z Podkarpatské Rusi,” Národní listy (22 June 1921), 1.

24 "Problémy Podkarpatské Rusi: Dopis z Užhorodu - 1," Československá republika (20 August 1920), 1.

${ }^{25}$ Richard Dušek, Podkarpatská Rus jindy a nyní (Mukacheve: Karpatia, 1927), 22.

26 "Z Podkarpatské Rusi," Národní listy (22 June 1921), 1.

${ }^{27}$ Josef Doškář, Veřejné zdravotnictví v Podkarpatské Rusi (Uzhhorod: Ždímal a Vetešník, 1921), 6.
} 
The image of Rusyns as willfully ignorant of the need for cleanliness and order also appeared in a Czech official's description of a typical highland village: "The houses of Rusyns are repulsive and terribly dirty. The houses in the countryside have no floors, only packed clay. They also have no wood stoves, just an open fire without a chimney." 28 This focus on hygiene as the root of civilizational progress reflects Anne McClintock's observation that soap and cleanliness brought "moral and economic salvation" to the European overseas colonies as well as "magically embodying the spiritual ingredient of the imperial mission itself." ${ }^{29}$ Encouraging Rusyns to wash and adopt Czech hygiene practices symbolized the process of bringing Rusyns into the modern world.

A further significant stereotype depicted the Rusyn people as simpleminded. An important symbol for this stereotype was the image of the "American" Rusyn, one of the many Rusyns who had gone to work in the United States and later returned to their ancestral villages in the highlands. The "American" Rusyn character played on the assumption that these Rusyns had seen modern ways of living and new technology in America, but had learned nothing from these experiences and returned to their traditional primitive way of life soon after returning home. Czech author Karel Čapek made such an "American" the central character in his 1933 novel Hordubal. In a memorable scene, the Rusyn Hordubal met his wife and daughter after eight years abroad and wished to impress them with an electric lamp he had carried back with him from the USA; however he was unaware that it required electricity to function and was left befuddled when he repeatedly pressed the switch and nothing happened. ${ }^{30}$

The image of the bumbling Rusyn "American" appeared frequently enough in the Czech press to suggest that the public found such a character an object of fascination, as a primitive who had been to the land of prosperity and progress and returned none the wiser. This symbolic character and his typically backwards behaviour were well described by a Czech official in Československá republika in 1920:

When a Rusyn comes back from America, or from overseas in general, to his native village, he is 'an American' only as long as he keeps wearing loose

\footnotetext{
28 “Z Podkarpatské Rusi,” Národní listy (22 June 1921), 1.

${ }^{29}$ Anne McClintock, Imperial Leather: Race, Gender and Sexuality in the Colonial Contest (New York: Routledge, 1995), 211.

${ }^{30}$ Karel Čapek, Three Novels: Hordubal, Meteor, An Ordinary Life (Highland Park, New Jersey: Catbird Press, 1990), 21.
} 
pants and an overcoat of the American style; when he gets re-accustomed to the local life, he slips back into the village life [...] without using any of the experience from what he saw or learned in America. ${ }^{31}$

This official went on to tell a story about an "American" Rusyn who visited a bank in Uzhhorod after arriving from the USA. The Czech bank clerk convinced the reluctant Rusyn to put his American earnings into an account at the bank, in spite of his original intention to take the money home and hide it under the bed. The following day the Rusyn returned and asked to withdraw all the money:

The 'American' watched as the clerk counted out the banknotes and when the clerk finished, suddenly our jolly man said that he wanted the money to be deposited again, that he only wanted to reassure himself that the money really was in the bank. When the clerk told me this story, he added: 'I would not be surprised at all if the man had asked if the banknotes were the same ones he had actually deposited. ${ }^{32}$

The official felt that the story "characterizes in the best way the soul of the local people" and provided evidence that Czech organization and guidance were essential for the territory, noting that "education is required starting with the basics!",33

The Rusyn weakness for alcohol was a further stereotype which appeared in many descriptions of Ruthenia in the early 1920s. Alcoholism symbolized the natural weakness of the Rusyn character, in contrast to the sober efficiency of the Czech nation. A Czech official condemned the thirst for brandy as the greatest evil afflicting the Rusyn people:

The passionate desire of the Rusyn population for alcohol is already wellknown. There is perhaps no other nation which has such a passion for alcohol as the Rusyns. During the Hungarian period the Rusyns could get as much alcohol as they wanted, and a Rusyn would sell his last piece of clothing, his wife, his children and even himself to get brandy. ${ }^{34}$

This description appeared on the front page of a major newspaper in the Czech capital Prague, and must have had an impact on the formation of public opinion. Chronic alcoholism in the villages of the Rusyn highlands was a significant problem, and as English travel writer Jessie Mothersole described, Czech officials devised a colourful policy to help fight the abuse of

\footnotetext{
31 “Problémy Podkarpatské Rusi: Dopis z Užhorodu - 2," Československá republika (22 August 1920), 1.

32 “Problémy Podkarpatské Rusi: Dopis z Užhorodu - 2," Československá republika (22 August 1920), 1.

33 “Problémy Podkarpatské Rusi: Dopis z Užhorodu - 2," Československá republika (22 August 1920), 1.

34 “Z Podkarpatské Rusi,” Národní listy (22 June 1921), 1.
} 
methylated spirits: "the authorities now insist that it shall be sold only mixed with a blue dye, and it will be a punishable offense to have blue lips." 35

Alcoholism as a fault in the Rusyn character could also be deployed for darkly comic effect. Writing in the early 1930s, a Czech official described the problems he saw in the territory: "Subcarpathian Ruthenia suffers from two main weaknesses: alcoholism, which is directly hereditary, and insufficient nutrition. If God is in first place among the ten commandments of the Rusyns, then brandy is in second place. ${ }^{, 36}$ Czech accounts of alcoholism in the highlands as a form of escape from poverty presented Rusyns as incapable of mastering their inner demons: "No wonder then, that when these people have the opportunity they resort to alcohol to try to brighten their miserable lives for a while. They don't know how to live any other way, they are like big clueless children." 37

Rusyns and Ruthenia could also be ascribed a stereotypical gender making them either masculine or feminine, correlating to analyses of femininity in Orientalist discourse and masculinity in Balkanist discourse. In a review of Czech Ivan Olbracht's film Marijka nevěrnice, shot on location in Ruthenia, Prague newspaper České slovo claimed the film portrayed "the cool sobriety of the Czech colonists, and the rebellious manliness of the Subcarpathian mountain folk." 38 The image of "rebellious manliness" among the highland Rusyns can be compared to Todorova's conception of Balkan masculinity as inherently primitive in Western eyes. However, in other cases Ruthenia could be considered feminine, as in this example from Prague newspaper Věstník obecni hlavniho města Prahy: "we call on the Czechoslovak people to save Subcarpathian Ruthenia, this most wretched daughter of our national family."39 In 1924 Olga Fastrová referred to the "feminine character" of the Rusyn people in Národní politika, ${ }^{40}$ while Našinec would later describe Ruthenia's decision to join the republic as that of a bride who had "chosen a Czech groom." Uncertainty over the gender which should be applied to Rusyns and Ruthenia reflects the duality of viewing the region as both a civilizational bridge and as a purely

\footnotetext{
35 Jessie Mothersole, Czechoslovakia: The Land of an Unconquerable Ideal (New York: Dodd, Mead and Co., 1926), 186.

36 “O Podkarpatské Rusi,” Národní listy večerník (23 March 1932), 1.

37 “Sociální péče v Podkarpatské Rusi,” Národní listy (3 March 1921), 1.

38 “Marijka nevěrnice," Večerni České slovo (1 March 1934), 1.

39 "Pomozte Podkarpatské Rusi!" Věstník obecní hlavního města Prahy (26 March 1920), 84.

40 Olga Fastová, "My a oni," Národní politika (29 March 1924), 2.

41 “Poslanec kanovník Světlík o významu Podkarpatské Rusi,” Našinec (7 August 1935), 1.
} 
colonial territory. The masculine image appeared when authors wished to present Ruthenia as ethnically Slavic and point out the positive features of the Rusyn character. The feminine image appeared when an author wished to cast Ruthenia as weak and in need of Czech organization.

Images reflecting Rusyn colonial stereotypes also appeared in cartoons published in the Czech newspaper Podkarpatské hlasy. As a newspaper published by and for Czech officials working in Ruthenia, the cartoons often carried the caption "based on true events" to suggest that they depicted an incident actually witnessed by a Czech official. ${ }^{42}$ The cartoons depict the first encounters in Ruthenia between scruffily-dressed Rusyn peasants and well-dressed, urban Czechs who stare in shock and surprise at the primitive behaviour of the Rusyns (see Figure 3.1). The peasants often have farm animals such as pigs or chickens with them to further the impression of their backwardness in contrast to the Czech characters in each cartoon. Stereotypical images include depicting Rusyns as simpleminded, primitive and uneducated alcoholics, in complete contrast with the sober and rational behaviour of the Czech characters represented. In one such example (see Figure 3.2) a Rusyn peasant and a Czech stand together watching a political speech. The politician pronounces that the source of the people's strength lay in unity and cooperation; the Rusyn then tells the Czech that this is false, that the true source of the people's strength also lay in alcohol. ${ }^{43}$ In another cartoon (see Figure 3.3) a Rusyn peasant tries to convince an astonished Czech railway conductor that his pig should be allowed to run along behind the train if it can't come with him in the carriage. ${ }^{44}$ Such picturesque and colourful images of daily life in Ruthenia cast Rusyns as childish and mentally simple, in need of strict guidance and supervision by the paternal Czech officials who formed the reading audience for the newspaper.

\footnotetext{
42 "Co se opravdu stalo!” Podkarpatské hlasy (9 June 1925), 3.

${ }^{43}$ Podkarpatské hlasy (28 March 1925), 3.

${ }^{44}$ Podkarpatské hlasy (21 April 1925), 3.
} 
Figure 3.1 - "Rusyn with Pig," $(1925)^{45}$

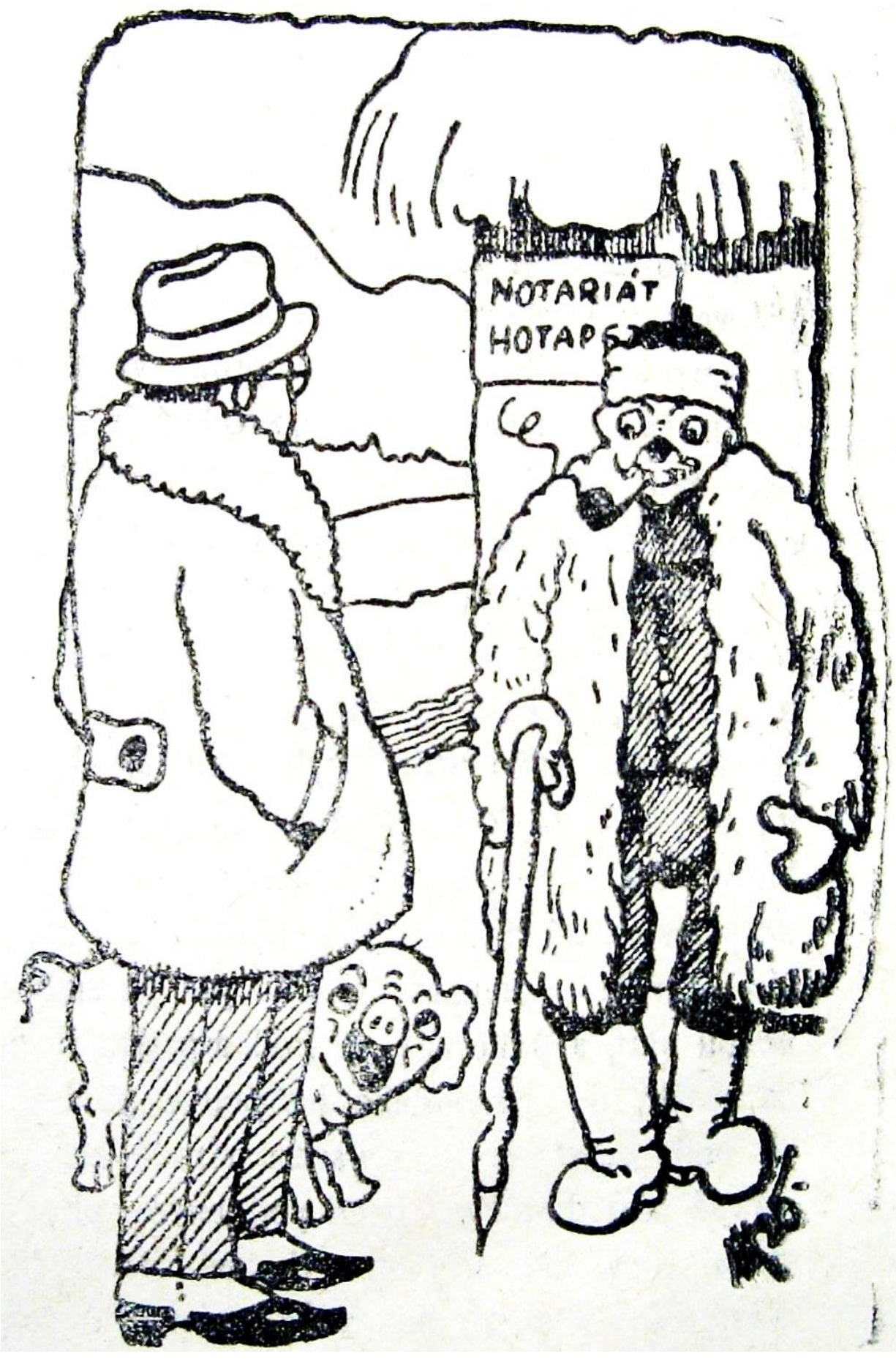

${ }^{45}$ Close-up from a cartoon in Podkarpatské hlasy (17 January 1925), 3. Photograph by the author. 
Figure 3.2 - "Election Speech," $(1925)^{46}$

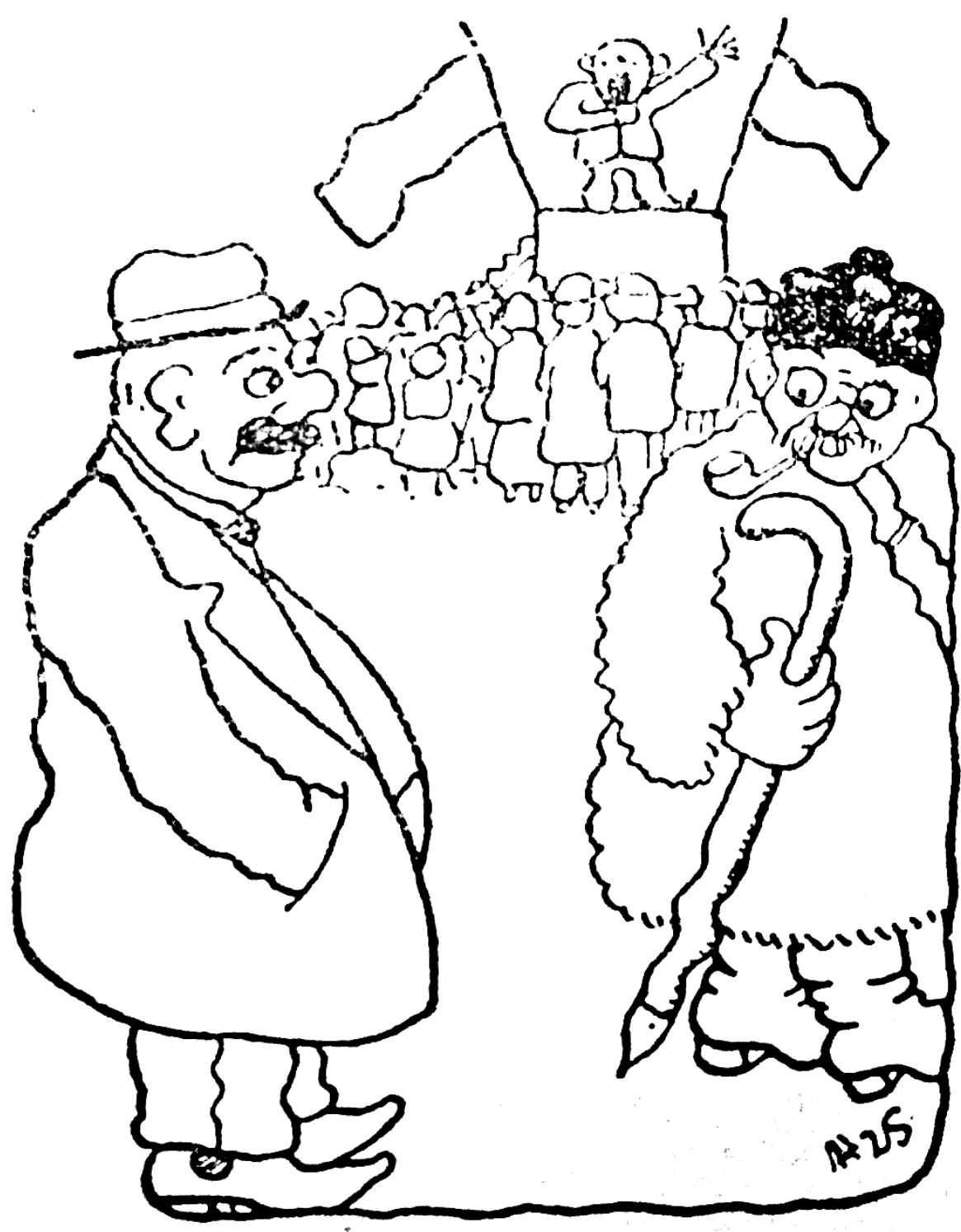

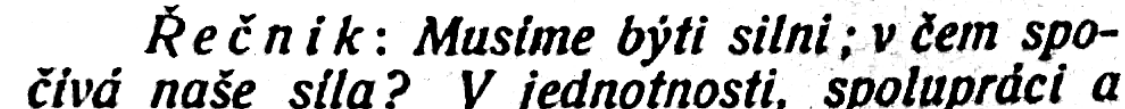
$v$ organisaci.

\section{Gazda: A na pálenku zabudnul.}

Speaker: "We must be strong, and what is the source of our strength? Unity, cooperation and organization."

Farmer: "But he forgot about brandy."

${ }^{46}$ Podkarpatské hlasy (28 March 1925), 3. Photograph by the author. 
Figure 3.3 - "On the Antalovtsi/Antalovec Railway line," (1925) ${ }^{47}$

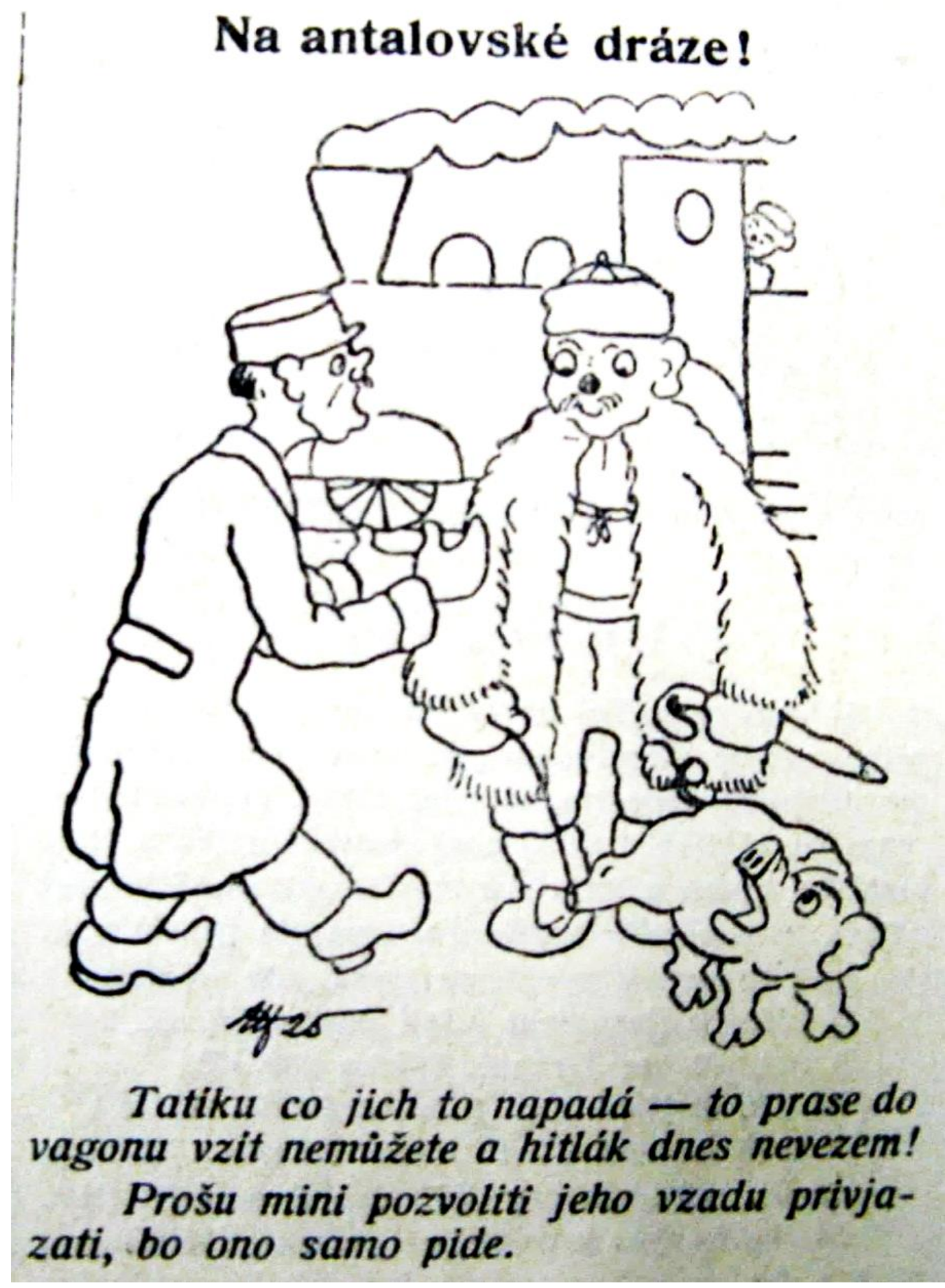

"Sir, what's the idea - you can't take this pig in the train carriage and there is no cattle wagon today!" "Please let me tie him to the back of the train, he'll run along on his own."

\footnotetext{
${ }^{47}$ Podkarpatské hlasy (21 March 1925), 3. Photograph by the author.
} 
Czech academics also devised racial hierarchies of Rusyns, comparing the physical attributes of the highland peasants to other racial groups. Anthropology professor Vojtěch Suk of Masaryk University in Brno published a paper which assessed the merits and defects of the different sub-classes of the Rusyn race. He began by stating that among all ethnic Rusyns "their general status is primitive," but he felt that the Hucul Rusyns of far-eastern Ruthenia were more advanced as a people, claiming that "their level of civilization is much higher than the other 'highlanders'." For Suk the highland Rusyns were "in every way much poorer, their costumes much simpler and less elaborate, their general level much lower and their physical traits different." He also considered the physical features of highland Rusyns to be inferior:

Whereas amongst the Huculs fine faces are not rare, here amongst the 'highlanders' the faces are quite different, also the stature and complexion. The skin is lighter and many times with a slight yellowish tinge, $[\ldots]$ and the stature is lower than that of the Huculs. ${ }^{48}$

Suk's assessment paralleled a conception among many Czech observers that the highland of Ruthenia was the most primitive corner of a backwards territory. ${ }^{49}$ His process of analysis also reflected the broader use of racial classification systems by anthropologists and ethnographers from Europe and the Western world in the early twentieth century. ${ }^{50}$

\section{Making Order out of Chaos: The Necessity of a Civilizing Mission}

Once Czech sensibilities had fully gauged the savage nature of Ruthenia and its Rusyn population, it was not easy to accept that the territory formed part of their new republic. In 1924, Dr. Karel Matoušek described the region as "half-Oriental, completely different from the Bohemian lands, chaotic and full of unrest." ${ }^{, 51}$ How could such a backwards territory with uncivilized people be integrated into the republic successfully? With Czech bureaucrats moving to Uzhhorod to take up the region's administration, Czech involvement in Ruthenia took on the symbolic representation of a civilizing mission to bring Western thinking to a land in Oriental

\footnotetext{
${ }^{48}$ Vojtěch Suk, "Anthropological and Medical Notes on the Peoples of the Subcarpathian Highlands," Man (May 1931, vol. 31), 90-91.

49 "Verchovina," Lidové noviny (3 December 1922), 4.

${ }^{50}$ E. Nathaniel Gates, from the Introduction to Racial Classification and History, E. Nathaniel Gates, ed. (New York: Garland Publishing, 1997), viii.

${ }^{51}$ Matoušek, Podkarpatská Rus, 5.
} 
disarray. References to a "civilizing mission" after the French term mission civilisatrice occurred in Czech publications in the early 1920s, including the following passage in well-respected daily Lidové noviny: "The task of the republic in Slovakia and Subcarpathian Ruthenia is to a considerable extent about civilizing these nations, and in Subcarpathian Ruthenia it is a civilizing task par excellence." 52 Czech academic Antonín Hartl declared in the early 1930s that President T.G. Masaryk also accepted the term: "If it is possible to summarize the opinion of Masaryk in one word about the task of the Czechoslovak Republic in this eastern region, it can be said that it is primarily viewed as a civilizing mission." ${ }^{, 53}$ The colonial connotations of the term "civilizing mission" must have been apparent to the reading public.

Justification for Czechs taking control of Ruthenia's administration rested on the assumption that the Rusyn people were too primitive to hold positions of responsibility. In a Government document in 1919 Otokar Růžička explained why this step was needed: "It is necessary to fill their government organs with Czechs, because the Rusyn people are not yet prepared for it, it will be necessary to start with them like with small children."54 Prague newspaper České slovo made a similar assessment of Rusyn capabilities in 1919: "What condition is Ruthenia in? It's hard to describe in one word! The best perhaps is primitive (in every way). It is necessary to do everything starting from A, B, C." 55 In 1921 Lidové noviny argued that giving the Rusyns political control of their affairs would be disastrous for the stability of the Czechoslovak state:

Is it possible to give autonomy to people who stand completely alone without intellectual leaders, without representatives of their national blood, able to effectively defend their own national rights? Is it possible to give autonomy to people for whom the concept of freedom is completely alien and perhaps even consider it a threat? ? $^{56}$

České slovo would also claim in 1923 that if Rusyns stood in the way of progress in the republic, "we must go against them" because "the interests of the state are greater than any

\footnotetext{
52 “Ministerský Předseda Dr. Beneš o politických otázkách,” Lidové noviny (26 December 1921), 2.

${ }^{53}$ Antonín Hartl, President Masaryk a Podkarpatská Rus (Prague: Antonín Hartl, 1932), 263.

${ }^{54}$ Otokar Růžička, Politické proudy v Přikarpatské Rusi, document of the Czechoslovak Ministry of Post and Telegraph (November 1919), 8. ANM Fond Brandejs, carton 2.

${ }_{55}$ České slovo (14 November 1919). ANM Fond Starý, carton 1.

56 “Autonomie Podkarpatské Rusi,” Lidové noviny (13 August 1921), 1.
} 
camaraderie." ${ }^{, 57}$ The assumption that Rusyns could not comprehend democracy and were totally unfit for self-rule left no room for argument on the subject of administration. If Rusyns were not able to take care of themselves, they would have to submit to Czech rule as it was in their own best interest.

Establishing moral justification for the civilizing mission by viewing it as a means of bringing western civilisation to Rusyns suffused many 1920s publications. Following a visit to Ruthenia in 1924, Dr. Karel Matoušek considered the improvements made in Rusyn public hygiene and cleanliness to be symbolic of the Western system of order imposed by the civilizing mission: "The new Czech regime is introducing order: we encourage the installation of water taps and plumbing, we have introduced state policies which have contributed heavily to basic sanitation in the towns, we highlight the importance of appropriate regulatory planning." 58 For Matoušek, bringing hygiene and civilization to the Rusyns offered a means for the Czech nation to prove its credentials as a truly Western nation. Other European great powers spoke of the "compassionate colonialism" of their global empires and the benefits they could bring to unenlightened corners of the globe, and Matoušek considered the Czech task in Ruthenia to have a comparably lofty goal. ${ }^{59}$

In response to Rusyn concerns that their right to political self-rule had been forgotten, Czech politicians, officials and authors focused on the need for order and organization in a region that would take years to develop economically and culturally. In 1921 Prime Minister Beneš described the stability of their administration as the best means of improving conditions in Ruthenia in the long term:

in this region by far the most important question is about communication, public hygiene, administration, and material goods, rather than questions about language, religion and so on, because good administration of the territory will solve half of these problems. ${ }^{60}$

Memories of Austrian rule remained fresh during the republic's early years, and Czech officials were aware they might be viewed in the same light as the imperialist masters who had once

\footnotetext{
57 “Podkarpatská Rus,” České slovo (20 November 1923). ANM Fond Starý, carton 1.

${ }^{58}$ Matoušek, Podkarpatská Rus, 220.

${ }^{59}$ Osterhammel, Colonialism: A Theoretical Overview, 35.

60 “Ministerský předseda Dr. Beneš o politických otázkách,” Lidové noviny (26 December 1921), 2.
} 
oppressed their own national ambitions. A Czech official described this concern over the autonomy question to British traveller Henry Baerlein:

'I dare say you will meet some people,' he smiled benevolently through his spectacles, 'who will tell you that this shows how tyrannous we are and that we have forgotten all the lessons of our own history, when the German Habsburgs kept us in subjection. ${ }^{, 61}$

Law Professor František Weyr reacted indignantly to the Rusyn request for political autonomy: "It is surprising how our Slavic brothers, who for centuries behaved like patient lambs towards their foreign oppressors, now have suddenly become generally impatient!" 62 It had taken centuries of cultural development before the Czech nation received autonomy, and such comments implied that Rusyns should not expect to make a similar claim for independence before they were ready to handle such responsibilities.

The Czech imagination's views of Ruthenia, according to the working model for Ruthenianism, hold parallels with both Said's Orientalism and Todorova's Balkanism. The territory became a half-European, half-Oriental bridge between east and west when Czechs wished to show that the region's inhabitants were Slavs who could potentially be lifted out of their primitive cultural state with appropriate Czech guidance. Inversely, Ruthenia could be seen as a purely Oriental colony when Czechs wished to highlight the civilizational differences between themselves and Rusyns while asserting their claim to be a Western nation. These two images of Ruthenia struggled for dominance in the Czech mindset during the early years of the republic when public opinion of the region was formed on the basis of exaggerated and sensationalist media accounts.

Colonial stereotypes of Rusyns developed along lines similar to Orientalist discourses evident in other regions of the world, with Rusyns cast as childish, primitive, unclean, simpleminded, passive, lazy, feminine or masculine, and alcoholics. These stereotypes appeared in the mass media from all sides of the political spectrum and in scholarly works. Stereotypes of primitive Rusyn behaviour suggested that they were unable to take care of themselves, providing moral justification for a Czech civilizing mission to make them cultured citizens of the new republic. This civilizing mission was established against the backdrop of a shift in colonial

\footnotetext{
${ }^{61}$ Henry Baerlein, Over the Hills of Ruthenia. (London: Leonard Parsons, 1923), 15-16.

${ }^{62}$ František Weyr, "Nejnovější Podkarpatská sensace," Lidové noviny (19 May 1921), 1.
} 
thinking by other European nations following World War One. Compassionate colonialism required the colonizers to consider their occupation of uncivilized territories as a form of training, a means of teaching Western values to less-developed peoples so that they might eventually be ready for self-rule. According to this requirement, the Czech elite needed to reassure themselves that they were not merely imperialists and were acting in the best interests of Rusyns. The dual nature of the Czech administrative role in Ruthenia, imagining themselves to be both efficient colonizers and compassionate caregivers, continued throughout the two decades of the First Republic and would contribute to further conflict with the Rusyn autonomists. Colonial stereotypes of Rusyns would also lead to direct comparisons to overseas colonies in Africa and Asia. 


\section{Chapter 4}

\section{Colonial Fantasies: Ruthenia Imagined as African and Oriental}

In December 1937, the Prague newspaper Polední list ran the provocative headline "Subcarpathian Ruthenia - our future colony" and claimed that regions of Ruthenia which were affected by malaria would be "suitable for colonization after its eradication" following practices used in French colonies (see Figure 4.1). ${ }^{1}$ Angrily rejecting the "colony" label, Rusyn newspaper Sotatskii Russkii vîstnyk condemned Polední list for "characterizing us as a colony," and claimed the author had "forgotten that the Rusyn nation joined the republic voluntarily, that the Rusyn nation is an autonomous nation on its territory." "Such depictions of Ruthenia as a colonial territory under Czech rule and angry rebuttals by the Rusyn elite occurred frequently throughout the twenty years of the First Republic. Czech use of colonial metaphors developed in conjunction with the observation that the Rusyn nation existed on a different civilizational level, that they were a people who, despite being Slavs, might not be considered truly European.

When Ruthenia joined the Czechoslovak Republic in 1919 the region and its people were all but unknown to the majority of the Czech population, and it would only be slightly better understood at the end of its twenty-year existence as a part of Czechoslovakia. Frequently inaccurate Czech media coverage had exaggerated the region's backwardness for greater reader impact, and Czechs imagined Ruthenia as the Czechoslovak Africa, a land of darkness and savagery, and as the Czechoslovak Orient, an outpost of exotic cultural practices closer to Asia than Europe. Such comparisons came from publications and politicians from across the political spectrum of Czech society, and through regular usage they entered into the public consciousness and vocabulary. The primitive and un-Czech character of Ruthenia held a powerful grip on the Czech imagination; for Czech authors and artists the region was a source of myth, magic and folktales that enabled them to craft stories of the exotic unknown, their own equivalent of colonial literature. Suzanne Zantop has observed that "colonial fantasies provide access to the

\footnotetext{
1 “Podkarpatská Rus - budoucí naše kolonie,” Polední list (24 December, 1937), 4.

2 “Podkarpatská Rus - budoucí naše kolonie," Sotatskii Russkii vîstnyk (16 January 1938), 1. See also "Podkarp. Rus' koloniia?” Russkii vîstnyk (9 January 1938), 2.
} 
'political unconscious' of a nation," ${ }^{3}$ and Czechs in search of adventure and a chance to escape from urban life found in Ruthenia a place where they could play out the fantasy of a visit to their own version of Africa, their own Orient.

\section{Figure 4.1 - Headline and Photographs from Polední list Article "Subcarpathian Ruthenia - Our Future Colony" (1937)}

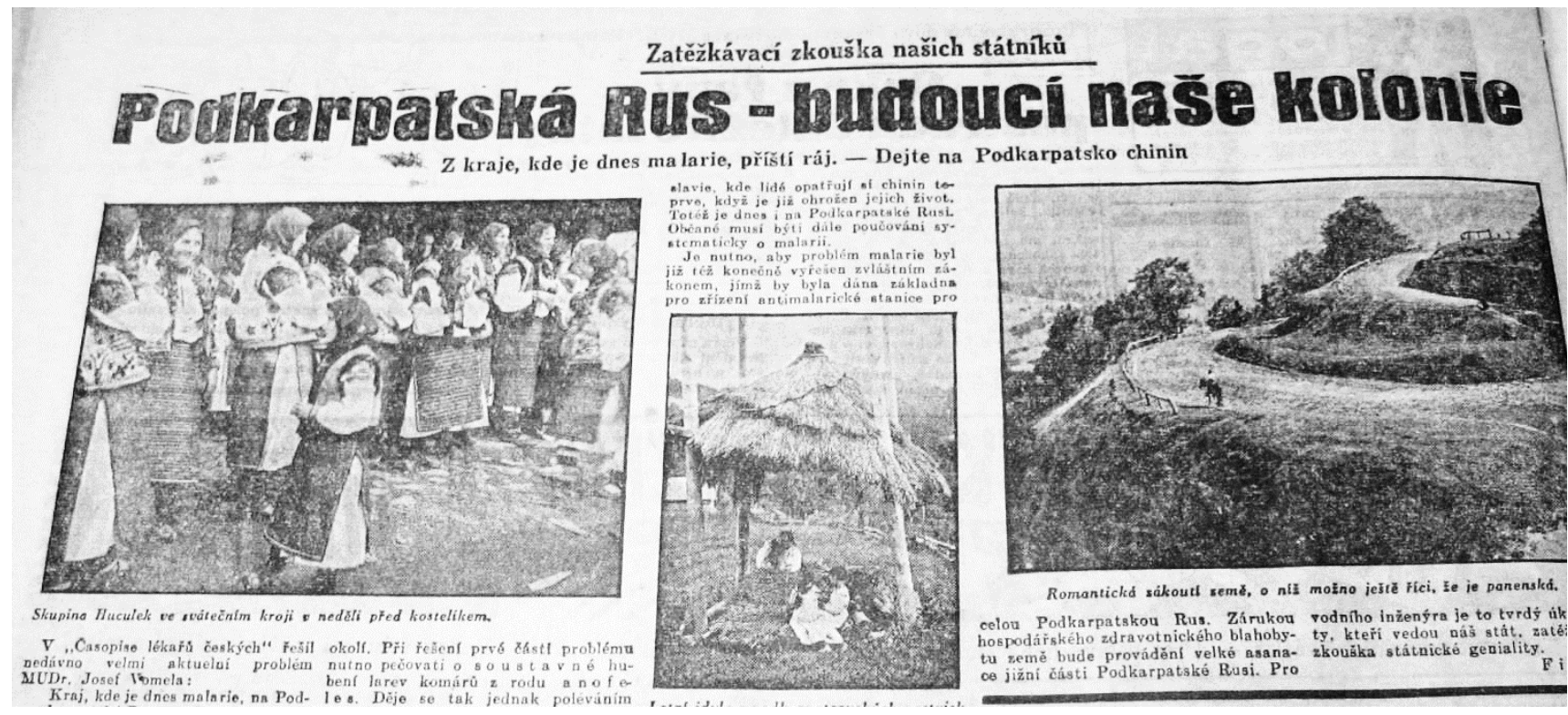

Use of colonial metaphors was not limited to Czech observations of Ruthenia, since they also appeared among the Rusyns themselves. As Chris Bayly has noted, both colonizers and colonized play an essential part in developing a colonial narrative. ${ }^{5}$ Although the Rusyn elite sought to disprove Czech colonial accusations, they also made use of the label to criticize their Czech administrators by comparing them to colonial masters in overseas territories. Since Rusyns compared their relationship with Czechs to colonizers and colonized they took part in constructing an imagined colonial space where both sides contributed to the development of a colonial discourse. This colonial fantasy cast onto Ruthenia would only vanish following Czechoslovakia's dissolution in 1939.

\footnotetext{
${ }^{3}$ Zantop, Colonial Fantasies: Conquest, Family and Nation in Precolonial Germany, 1770-1870, 4.

4 "Podkarpatská Rus - budoucí naše kolonie," Polední list (24 December, 1937), 4. Photograph by the author. ${ }^{5}$ Chris Bayly, Empire and Information: Intelligence Gathering and Social Communication in India 1780-1870 (New York: Cambridge University Press, 1996), 6.
} 


\section{Questioning Ruthenia's Europeanness}

As a reflection of the lack of knowledge about Ruthenia among the Czech public, repeated references to the territory as a terra incognita appeared in Czech publications throughout the period of the Czechoslovak First Republic. Describing Ruthenia in the early 1920s, Czech author Antonín Hartl claimed that "this land and its people were unknown to us, a terra incognita." is said about Subcarpathian Ruthenia, neither its culture nor its economic characteristics."7 Český deník later announced in 1932 that "Czechoslovakia was stunned by the surprising news that Subcarpathian Ruthenia actually existed" following an "expedition for journalists to go and discover the terra incognita." 8 The term appears so frequently in the Czech media of the period that it suggests a fascination with calling Ruthenia an "unknown land" in the tradition of European global exploration. Czech Jaroslav Durych, a physician working in Uzhhorod, described the intangible and undefinable nature of Ruthenia in the Czech psyche: "Subcarpathian Ruthenia is like a ghost, it is necessary to quickly grasp it before it disappears, to give it true reality."

Czech publications pointed to the fundamental differences in cultural development between Ruthenia and the Bohemian lands and hinted that the territory could not truly be considered European. Prague Jewish publication Rozvoj described the state of the Rusyns and Jews in Ruthenian villages in 1932:

There is misery in Subcarpathian Ruthenia. Awful misery. Both physical and mental. It makes it hard to believe that Subcarpathian Ruthenia is really in Czechoslovakia. Or in Europe. ${ }^{10}$

Questioning the Europeanness of Rusyns established a viewpoint of superiority, casting Czechs as cultured Europeans bringing civilization to the non-European Rusyns. Reflecting on the terrible conditions in Ruthenia in 1926, Podkarpatská Rus, written for an audience of Czechs working in Ruthenia, posed a question: "We must ask if we are in Europe, or in some Papua New

\footnotetext{
${ }^{6}$ Antonín Hartl, Podkarpatšti Rusini a my (Prague: A. Hartl, 1930), 3.

7 "Podkarpatská Rus," Český deník (5 August 1930), 1.

8 “Podkarpatská Rus," Český deník (19 March 1932), 1.

9 Jaroslav Durych, Duše Podkarpatské Rusi (Prague: Přátel Podkarpatské Rusi, 1993), 11.

10 “Podkarpatská Rus," Rozvoj (8 April 1932), 4.
} 
Guinea." ${ }^{11}$ Prague magazine Pestrý týden suggested in 1927 that the Czech public might not only be unsure if Rusyns were truly European but perhaps even if they were Christian, though the author wished to condemn such opinions:

It is said that Subcarpathian Ruthenia is a savage land and its people are uncultured, we've heard this said many times and we know all about it. But is this really so? Are the people there really uncultured? Is it possible that they are merely uncivilized? [...] If the most cherished symbol there is not a circle or a crescent moon but instead a cross, and matching colours - white, blue and red, this is only logical, because the people there are Christian and Slavic in all their behaviour. ${ }^{12}$

This suggestion that the Czech public could have doubts about whether they would find an Islamic or Christian culture in Ruthenia emphasizes how a lack of general knowledge could precipitate the leap from seeing Rusyns as uncultured to questioning their right to be considered European and Slavic.

Once the Europeanness of Rusyns had been called into question, comparing Ruthenia directly to an African or Oriental colony became a natural progression. As we saw in the previous chapter, a process of stereotyping Rusyns in the media as naturally inferior and primitive permitted them to be cast as an "Other" in the Czech imagination. Contrasting civilized Czechs against the behaviour of uncivilized Rusyns soon led to questioning the right of Rusyns to be called European, Christian and Slavic. It fulfilled in the Czech mindset both an exotic colonial fantasy they could call their own and an unconscious desire for the newly ascendant Czech nation to spread its influence.

Czech interest in Africa and the Orient had already existed during the Austro-Hungarian period and continued following the formation of Czechoslovakia. Sarah Lemmen has shown that travellers' accounts and novels about the Orient "were as popular in the Bohemian lands as they were throughout the rest of Europe" during the nineteenth century. ${ }^{13}$ Czech perceptions of the Orient developed in part from their viewpoint as citizens of Austro-Hungary, with the Ottoman

\footnotetext{
11 “Podkarpatská Rus - Eldorado všech cizích dobrodruhů,” Podkarpatská Rus (20 March 1926), 3.

12 "Umění na Podkarpatské Rusi,” Pestrý týden (18 May 1927), 5.

${ }^{13}$ Lemmen, "Noncolonial Orientalism? Czech Travel Writing on Africa and Asia around 1918," 213.
} 
Empire and Bosnian Slavs under Habsburg rule deemed part of the Orient. ${ }^{14}$ During the interwar period the formal study of the Orient became a significant endeavour at Charles University in Prague, and a Czech Oriental Institute promoted economic engagement with non-European regions of the world. ${ }^{15}$

Evidence of Czech public interest in the overseas colonies of other European nations abounds in the many Czech-language publications and translations which appeared before and during World War One. Books by Czech adventurers who had travelled in Africa, Asia and the Middle East became popular, including those by authors such as Vilém Němec, Jan Rosůlek and Jan Havlasa. Němec published Má cesta do Afriky [My journey to Africa] in 1916, describing his trip from Prague to central Africa by land, ${ }^{16}$ while Rosůlek's Vioně Afriky [Scent of Africa] recounted his adventures in North Africa in the early 1920s. ${ }^{17}$ Jan Havlasa (real name Jan Klecanda) wrote books about his adventures in many corners of the globe before and during World War One, such as Cesta kolem světa [Journey around the World] in 1914 and Düm $v d \check{z} u n g l i$ [House in the Jungle] in 1916, filling the pages with swashbuckling tales of his heroics among the natives of distant lands.

Czech interest in acquiring a colony also had a precedent in the campaign for a Czech Togoland led by Jan Havlasa towards the end of World War One. Havlasa became interested in the idea that an independent Czechoslovak state could acquire former German colonies abroad in Africa or New Guinea, and he considered a claim for the former German colony of Togoland in West Africa to be particularly promising. With the aim of building support among the Czech public for requesting Togoland at the Paris Peace Conference, he published a book called České kolonie zámořské [A Czech Overseas Colony] in early 1919. Havlasa tried to convince the public that obtaining a colony in Africa for Czechoslovakia was a real possibility:

It is not as absurd as it would appear to many people if we speak of a Czech overseas colony, when for example they read a report about the possibility of ceding African Togo to the Czechoslovak Republic. [...] A Czech overseas

\footnotetext{
${ }^{14}$ Johann Heiss and Johannes Feichtinger, "Distant Neighbors: Uses of Orientalism in the Late-Nineteenth Century Austro-Hungarian Empire," in Deploying Orientalism in Culture and History: From Germany to Central and Eastern Europe, James Hodkinson and John Walker, eds. (Rochester, New York: Camden House, 2013), 148.

${ }^{15}$ Lemmen, "Noncolonial Orientalism? Czech Travel Writing on Africa and Asia around 1918," 213.

${ }^{16}$ Vilém Němec, Má cesta do Afriky (Prague: Ant. Svěcený, 1916).

${ }^{17}$ Jan Václav Rosůlek, Vůně Afriky (Pardubice: Vlastimil Vokolek, 1925).
} 
colony isn't a journalistic red herring, as it would appear on first glance from the Central European provinces. ${ }^{18}$

As a politically active Czech patriot who had pushed for Czechoslovak independence, Havlasa attended the Paris Peace Conference as part of the Czech delegation. The Czech press carried stories expressing the possibility of receiving Togo as a colony from the peace conference, though few journalists shared Havlasa's optimism. Prague newspaper Národní politika poked fun at Havlasa's hopes for Togoland saying the idea "made them laugh."19 Havlasa's dream proved to be completely unfounded as Britain and France carved up Togoland between themselves. However, his enthusiasm for Czech elites to expand their influence abroad is not so surprising. His dream of an exotic African colony for Czechoslovakia mirrored colonial fantasies that would be cast onto Ruthenia by Czech journalists and authors just a few years later.

Colonial rhetoric similar to Havlasa's appeared in descriptions of Ruthenia by Czech officials. Just a month after Ruthenia joined the republic in October 1919, Secretary of the Czechoslovak Post and Telegraph Ministry Otokar Růžička described how his "first-hand experience" of "the colonial practices of England, France and Germany" based on his travels in Asia could help him to understand the task ahead in Ruthenia. He had observed that the "single idea" of overseas colonial enterprises was to "strengthen in every way the ties of the colony to the motherland." He lamented that "working together for the flowering and expansion of our country is something we are still lacking" in "our colony Ruthenia" due to internal divisions among the Rusyn intelligentsia. ${ }^{20}$ A Czechoslovak Ministry of Education publication in 1931 also drew parallels between the Czech administrative experience in Ruthenia and overseas colonial administrations. Describing the possibilities for expanding the economic trading potential of Czechoslovakia in the Orient, author Emil Ženaty claimed that Czechs already had some helpful experience as "colonial" organizers, since their "work in the nearest east - Slovakia and Ruthenia - can be called 'colonial'."21 However, the majority of Czech comparisons made between Ruthenia and an overseas colony occurred in the media and focused on two geographic regions, either an African Ruthenia or an Oriental Ruthenia.

\footnotetext{
${ }^{18}$ Havlasa, České kolonie zámořské, 12-13, 15-16.

19 “Jak jsou loveni krokodilové v Africké Kolonii Togo,” Národní politika (1 February 1919, Afternoon Edition), 1.

${ }^{20}$ Otokar Růžička, Politické proudy v Přikarpatské Rusi, document of the Czechoslovak Ministry of Post and Telegraph, 12 November 1919. ANM Fond Brandejs, carton 2.

${ }^{21}$ Emil Ženaty, Hospodářské základný Československé v Orientu (Prague: Masarykova akademie práce, 1931 ), 13.
} 


\section{An "African" Ruthenia}

Comparing Ruthenia to Africa enabled Czechs to place the territory on a different civilizational plane from their own, and to criticize what they perceived as primitive behaviour there. Colonial stereotypes had positioned the Rusyn people at the level of savage cultures, and placing Ruthenia metaphorically outside Europe reinforced these stereotypes. One of the earliest Czech comparisons of Ruthenia to an African colony appeared in Vojtěch Lev's Brána na Východ [Gateway to the East] in 1920. While blaming the former Magyar rulers of Ruthenia for the problems Czech officials faced there, Vojtěch claimed that "The Hungarians turned Subcarpathian Ruthenia into a piece of darkest Africa,"22 and summarized the difficult task ahead for Czech officials: "A lot of work and patience will be needed if we wish to make a part of cultured Europe out of this corner of darkest Africa." ${ }^{, 23}$ Prague newspaper České slovo was also among the first to use the terms "African" and "land of darkness" to describe Ruthenia: a 1921 report on conditions in Ruthenia appeared under the headline "From Subcarpathian Ruthenia: the Land of Darkness," 24 while in 1923 the newspaper would lament that "unfortunately this unknown land is still an Africa.",25

The African colonial metaphor also entered the speeches of Czechoslovak politicians, bringing the idea of an African Ruthenia to a broader audience. In 1922 Prime Minister Beneš described Ruthenia as "African" during a speech about the slow pace of progress in the territory, claiming that it was "necessary to object to the conditions there so that Subcarpathian Ruthenia is not spoken of as if it were an African colony." ${ }^{26}$ Nová doba also described the Prime Minister's speech, reporting that he encouraged officials serving in Ruthenia to "work very hard" to prevent public acceptance of the "African colony" label. ${ }^{27}$ The colonial Africa metaphor also appeared as a means of scoring political points against the ruling Czechoslovak Agrarian Party. In 1924 the Czechoslovak People's Party [Československá strana lidová] claimed that "Subcarpathian Ruthenia is a dark Africa for us, we don't have a clue what is happening there. The so-called

\footnotetext{
${ }^{22}$ Lev, Brána na východ, 16.

${ }^{23}$ Lev, Brána na východ, 20.

24 "Z Podkarpatské Rusi: Z kraje temnoty," České slovo (30 December 1921), 2.

25 "Podkarpatská Rus,” České slovo (20 November 1923). ANM Fond Starý, carton 1.

26 “'O poměrech v Podkarpatské Rusi,” Národní politika (13 January 1922), 2.

27 “Poměry v Podkarpatské Rusi," Nová doba (13 January 1922), 2.
} 
'experts' sit in their offices or elsewhere, they don't care about the region and so for them it remains unknown., 28

Comparisons of Ruthenia to Africa also appeared in the speeches and writings of Czechoslovak Socialist Party leader Václav Klofáč. In a speech to the Czechoslovak senate in 1924 he directly compared Subcarpathian Ruthenia to a "black Africa": "Subcarpathian Ruthenia never had any schools, nor education, nor anything. I never in the world saw such a black Africa as in the highlands of Subcarpathian Ruthenia." ${ }^{29} \mathrm{He}$ may have said "black Africa" for increased impact on his audience in the senate, but Klofáč's use of the term was a powerful colonial image for the ears of his influential listeners. In a speech to members of the Czechoslovak Red Cross a year earlier, Klofáč had condemned Hungary for its neglect of the Rusyn people and claimed that Czechs had an important role to play in reviving Ruthenia. However, he cautioned the Red Cross workers to remember that they should not think of the territory as a Czech colony:

Hungary meant death for Subcarpathian Ruthenia, the Czechoslovak Republic must mean life for it. This is a land of poverty and darkness, but we can see that these people are not yet beaten. I extend my hand to everyone from Subcarpathia. Subcarpathian Ruthenia is not our colony, nor is it a temporary union, Subcarpathian Ruthenia is a definitive part of the republic. We are one body, and what we are doing for Subcarpathian Ruthenia we are also doing for ourselves, for our republic. ${ }^{30}$

Klofáč's refusal to accept that Ruthenia should be called a Czech colony suggests that his audience had already absorbed the colonial metaphor from its frequent use in the media.

Images of Ruthenia as an African colony also came from the Czech officials who lived and worked in the territory. In 1926 the Uzhhorod newspaper Podkarpatské hlasy, for a readership of Czech officials in Ruthenia, defended the author of an article in Československé legionári who had spoken of the harsh conditions and isolation which soldiers posted there as gendarmes faced. In an article titled "Daleko od Evropy" [Far From Europe], Podkarpatské hlasy compared the plight of these Czech gendarmes to colonists arriving in Africa:

Consider if this small territory - Subcarpathian Ruthenia - wasn't specifically named and you were alone there in enforced exile and didn't know where you

\footnotetext{
28 "Pražské zprávy," Našinec (27 March 1924), 2.

${ }^{29}$ Václav Klofáč, Speech to the Czechoslovak senate, 5 November 1924, session 232.

30 “Senátor V. Klofáč,” Zpravy Československého červeného křiže (15 March 1923), 39.
} 
were. In your imagination a geographical shift would occur, and in your mind's eye would emerge an oasis on the banks of the river Zambezi. ${ }^{31}$

These words in Podkarpatské hlasy colourfully describe the development of the Czech colonial fantasy towards a land some considered to be the Czechoslovak version of a heart of darkness.

The African colonial metaphor for Ruthenia did not go unnoticed by Rusyn intellectuals, who criticized Czech use of the term and its imperialist implications. Rusynophile autonomist leader Kurtiak's Karpato-Russkii vîstnyk reminded Czechs in 1923 that "we live in the twentieth century and not in dark Africa among the wild nations, but in cultured Europe and among cultured nations." ${ }^{32}$ The Rusyn intelligentsia also reacted to foreign media sources which had labelled Ruthenia as "African;" in 1922 Vpered rejected the claims of Vienna newspaper Neues Wiener Tagblatt after it called Ruthenia "an uncultured African territory." 33 Despite their rejection of the label, the Rusyn elite would also use the term themselves, reflecting their role in a colonial discourse.

Rusyn intellectuals made use of the colonial metaphor as a means of criticizing the Prague government and the Czech officials working in Ruthenia. In 1921 Ruthenian Communist Party leader Ivan Mondok used the term to attack the Czech administration as well as the capitalist system of the republic: "we [Rusyns] are slaves, an eastern colony of Czech imperialism."34 Kurtiak's organ Russkii vîstnyk claimed in 1927 that all the improvements in services Czech rule had brought to Rusyns were no different than European colonial practices in Africa:

New roads, schools, bridges, cultural institutions, land improvement, courses for the illiterate. [...] In African colonies these things are provided too, by the English, French and others, not for the benefit of the populace but for better exploitation of the colony. ${ }^{35}$

Use of the African colonial metaphor to attack the Czechoslovak government came predominantly from Communist and Social Democrat members of the Rusyn intelligentsia, but it also became a tool to criticize the activities of Czech officials working in Ruthenia.

\footnotetext{
31 “Daleko od Evropy," Podkarpatské hlasy (4 February 1926), 2.

32 "Cheshsky uchenŷ y nash iazŷk,” Karpato-Russkii vîstnyk (21 January 1923), 4.

33 "Shche oden znatok Podkarpats'koî Rusy!" Vpered (22 January 1922), 2.

${ }^{34}$ Shliakom zhovtnia: Zbirnyk dokumentiv, volume 2, document 236 (Uzhhorod, 1961), 87; as quoted in Magocsi, The Shaping of a National Identity, 195.

35 “Yz Bosniatskykh 'hlas'-ov,” Russkii vîstnyk (31 March 1927), 1.
} 
Rusyns considered many of the Czech gendarmes and border guards who lived among them to be corrupt ${ }^{36}$ and this led to descriptions of these officials as an "African Order" at work in Ruthenia. In a letter to the editor of Karpato-Russkii vistnyk in January 1923, the mayor of the town of Velykyi Bychkiv described the visit of a Czech border guard inspector to his settlement and the dismissive attitude such inspectors and Czech border guards had for the local Rusyns:

I introduced myself to the 'divinely chosen' inspector and he started to shout at me 'Shut up, I do not acknowledge any mayor here' and at his command four border guards hit me in the abdomen with their bayonets and shouted at me to leave. Golden Prague is happy to have such officials as this inspector and border guards. They behave among us as if they were in Africa and they treat us as if we were animals.

This image of discrimination at the hands of Czech officials contrasts sharply with the Slavic ideals the Prague government wished to project at that time. The Rusyn mayor then demanded an end to the "African Order" imposed by Czech officials who "drink our blood" and demanded that the Czechoslovak government intervene and discipline the officials: "We ask that these scoundrels be sent back to Prague, and if there is no place for them there, send them to Africa where they can make fortunes for themselves instead of here among us Rusyns." ${ }^{37}$ The mayor's use of the African metaphor turned the tables in the Czech-Rusyn civilizational balance; suddenly Rusyns held the moral high ground against the uncivilized behaviour of these Czechs. In doing so he defended Rusyn claims to European civilization while casting the Czech officials as colonial oppressors.

Depictions of Ruthenia as an African colonial territory also appeared in publications from other European states. In 1921 Vienna newspaper Neues Wiener Tagblatt suggested that during the two years of their administration in Ruthenia Czech officials had done their best in a savage territory: "The worst irredentism rages in this uncultured African land, because the people of Subcarpathian Ruthenia were kept in cultural darkness until the twentieth century and were treated like inferior cattle. ${ }^{„ 38}$ Prague newspaper Československá republika approved of this antiHungarian description and agreed with the comparison of Ruthenia to an "African land." 39 A subsequent article in Československá republika in 1922 may have paraphrased the words quoted

\footnotetext{
${ }^{36}$ Rusyn accusations of corruption in the administration in the 1920 s are addressed in detail in chapter 5 .

37 "Afrykansky poriadky," Karpato-Russkii vîstnyk (21 January 1923), 10-11.

38 "Bosna Československého státu," Československá republika (29 December 1921), 4.

39 “Bosna Československého státu," Československá republika (29 December 1921), 4.
} 
from Neues Wiener Tagblatt a few months earlier, describing Hungarian revisionist tactics in Ruthenia as "the foreign propaganda which rages in the middle of the African wilderness in this wretched territory." 40

In the 1930s the Hungarian and Polish media made use of the "African colony" label to describe the Czech administration of Ruthenia as imperialist. Poland offered support to Hungary's revisionist cause as part of its own goal to reclaim the lost region of Těšín/Cieszyn and to regain a common border with its close ally. In 1935 a Polish journalist from Warsaw named Popławski published an article titled "The Black Land of the Czechoslovak Republic" after a visit to Ruthenia. ${ }^{41}$ Writing in the Plzeň newspaper Český deník, Czech MP František Lukavský responded to the main points Popławski had made in his article:

Poplawski describes his trip further and writes about local political and economic affairs. Subcarpathian Ruthenia is supposedly for Czechs a kind of economic concession in the Rusyn jungle. [...] In the dictionary of civilized people there are no adequate expressions which could describe life in this land of cave people. Poplawski saw people there who resembled living skeletons, saw children who resembled those in photographs from regions of Soviet Russia suffering from starvation. A Czech official explained to him about all the lazy people there who don't want to work! Didn't European plantation owners say the same thing about their slaves? ${ }^{42}$

Lukavský rejected Popławski’s accusations of a Czech colonial regime as absurd and greatly unfair, but he was willing to admit that the Prague government had made mistakes and that such foreign opinions should act as motivation to redouble Czech efforts in Ruthenia. ${ }^{43}$

Widespread use of the African colony metaphor by Czechs, Rusyns and foreign observers contributed to a broader colonial discourse between Ruthenia and the Bohemian lands. With Ruthenia considered a primitive terra incognita in the Czech imagination, placing it symbolically in Africa gave further resononace to the common colonial stereotypes of Rusyn behaviour. While Czechs used the "Africa" term to underscore their civilizational superiority in the relationship, Rusyns rejected efforts to cast them as un-European and used the label to criticize the behaviour of Czech officials and the autocratic approach of the Prague government.

\footnotetext{
40 “Podkarpatská Rus,” Československá republika (23 March 1922), 1.

41 “Kritika poměrů na Podkarpatské Rusi," Český deník (24 December 1935), 1.

42 “Kritika poměrů na Podkarpatské Rusi," Český deník (24 December 1935), 1.

43 “Kritika poměrů na Podkarpatské Rusi," Český deník (24 December 1935), 1.
} 


\section{"The Czechoslovak Orient"}

Comparisons to the Orient and Asia also featured prominently in Czech publications on Ruthenia. While the image of "African Ruthenia" focused on the territory's primitive cultural level, use of the Oriental metaphor highlighted not only its backwardness but also its exotic and mysterious allure in contrast to the Bohemian lands. Ivan Pop, one of the most prominent scholars of Rusyn history in the Slavic world, has described Czech knowledge of Ruthenia in this fashion: "for the Czech public this territory appeared as a great unknown, like a dark corner of the Orient in Central Europe, an 'Asia' beyond Košice." ${ }^{44}$ Pop's terminology reflects the abundant usage of these labels in Czech newspapers, magazines and books during the interwar period.

In contrast to the purely primitive connotations of the "African" label, the "Oriental" metaphor for Ruthenia often appeared in Czech descriptions as "half-Oriental," suggesting Ruthenia was a bridge between east and west which could potentially be Europeanized under Czech tutelage. For instance, Karel Matoušek described Ruthenia's cities as "half-Oriental" due to their lack of basic infrastructure such as water pipes and sewers, while suggesting that Czech investments could bring the cities to the standard of others in the republic. ${ }^{45}$ When describing Ruthenia's first elections in 1924 Czech newspaper Moravsko-slezský denník spoke of the vote by the "Carpatho-Rusyn Asians," claiming that "if today Ruthenia is half-Asian, during the Hungarian regime it was Asia." 46 The suggestion that Ruthenia might lose its "Asian" or "Oriental" character with enough Czech resolve and education reflected an important aspect of the civilizing mission and Osterhammel's observations on the nature of "compassionate colonialism. ${ }^{, 47}$

Czech suggestions arose that the dividing line between eastern and western civilization ran through the republic, leaving Ruthenia (and sometimes Slovakia as well) on the "Oriental" side. Národní politika characterized the far eastern territory as an Oriental outpost:

\footnotetext{
${ }^{44}$ Ivan Pop, “Jak se vyvíjely názory Čechů na národní identitu Rusínů,” Podkarpatská Rus: časopis společnosti př́tel Podkarpatské Rusi (Prague: Rudolf Valenta, January 2012), 8.

${ }^{45}$ Matoušek, Podkarpatská Rus, 219.

${ }^{46}$ Moravsko-slezský denník (18 March 1924), ANM Fond Starý, carton 1.

${ }^{47}$ Osterhammel, Colonialism: A Theoretical Overview, 35.
} 
Subcarpathian Ruthenia is already close to the Orient. Can we accept this, that part of our state is integrated with the west, and the other is part of eastern culture? Is it only a phrase, that we are a bridge between these two cultures? Those who have the opportunity to see what Subcarpathia's inhabitants are capable of at the present time in our country [...] must come to the opinion that they are still Oriental. ${ }^{48}$

Olga Fastrová made a similar observation in 1924 in a feuilleton for Národní politika, casting Ruthenia and Slovakia as part of the "Orient":

The border between east and west Europe runs right through the middle of our republic. [...] Our half of the republic - this is the West, this is America or France in miniature. The people here are literate, and therefore self-confident. [...] Here there is no master or slaves. But there? It is the East, the Orient. ${ }^{49}$

Czech concern for this civilizational divide within the republic reflected doubts over the Prague government's ability to successfully integrate and westernize such intrinsically backwards peoples, despite their common Slavic ethnicity.

Oriental and Asian colonial rhetoric to describe Ruthenia appeared in many different sectors of Czech society, including arts and entertainment. Journalist Miroslav Rutte referred to Ruthenia as "the Orient of our republic" when describing the territory's appeal as exotic subject matter to inspire Czech authors. ${ }^{50}$ In 1933 Národní listy discussed the state of the fledgling Czech film industry and suggested that there were opportunities for Czechs to begin making more artistic films about "exotic" cultures since such cultures existed within the republic. The author suggested that Ruthenia offered a ready supply of material for making films about "primitive people":

There are many possibilities for the Czech film industry in this direction: there is Slovakia, and there is the Orient of the republic, Subcarpathian Ruthenia, which is a potential source of untapped riches of primitive people and their way of life. It is only necessary to be sensitive and caring when aiming for the objective, to create an engaging exotic film.

The author compared the opportunity to make films about primitive Rusyn culture to other "Oriental" films recently produced in Soviet Central Asia by Russian filmmakers. ${ }^{51}$

\footnotetext{
48 “Podkarpatská Rus nejsou Čechy," Národní politika (14 April 1932), 3.

${ }^{49}$ Olga Fastrová, "My a oni," Národní politika (29 March 1924), 2.

${ }^{50}$ Miroslav Rutte, "Bohatýrský román a zbojníku Šuhajovi," Národní listy (24 March 1933), 5.

51 “Co chybí českému filmu?” Národní listy (11 September 1932), 10.
} 
Czech awareness of the unique culture and customs found in Ruthenia increased in the early 1930s, resulting in demand for exhibitions of Rusyn folk art, music, dance and daily peasant life. This interest focused on the exotic differences of Rusyn culture from the Bohemian lands and is comparable to the popularity of colonial exhibitions across Europe at that time; Anne Maxwell has observed how the "visual representation of colonized peoples as savages" in exhibitions gave Europeans a "framework for identity based on racial and cultural essences."52 Such exhibitions allowed Czechs to see the culture and way of life of the Rusyn "Other," and promotion of these events typically described them as "Oriental." For instance, in December 1933 Prague newspaper Národní politika featured a photo of an exhibition of traditional Rusyn artifacts, and described selecting which items to buy based on their exotic difference: "I have in mind Carpatho-Rusyn woven carpets, from a corner of the Orient in our territory, items which will look good when displayed in today's modern apartments." 53 Six historic Rusyn wooden churches, symbols of Rusyn culture and much admired for their architectural beauty, were dismantled and transported to the Bohemian lands to be displayed as cultural curiosities for Czechs to enjoy. ${ }^{54}$

Interest in the exotic Rusyn culture led to the creation of travelling exhibitions of art and cultural performances which toured Czechoslovakia and abroad. While watching Rusyn folk dancers in a Prague hall in 1936, a Rusyn-American observer compared the captivated audience's reaction to a Parisian audience he had recently seen watching dancers from a French West African colony. He admonished the Rusyn performers to show "a little more pride in Rusyn culture, a little more wisdom - don't go back to Prague like negroes!"55 The following year Prague newspaper Prítomnost described a Czechoslovak tourism exhibition in Paris and how it marketed Ruthenia to French tourists:

The slogan they have chosen to describe Subcarpathian Ruthenia is The Slavic Orient. Perhaps a number of Czechs would object that Uzhhorod is not the Orient. Being labelled as 'Slavic' excludes the possibility that a Frenchman

\footnotetext{
${ }^{52}$ Anne Maxwell, Colonial Photography and Exhibitions (London: Leicester University Press, 1999), ix.

53 "Lidové Umění," Národní politika (21 December 1933), 1.

${ }^{54}$ Today these Rusyn wooden churches can still be found in the Czech Republic: the most prominent stands on Petřín hill in the centre of Prague, while others can be seen in a park in the city of Hradec Králové, in the towns Nová Paka and Blansko, and in the villages of Kunčice pod Ondřejníkem and Dobríkov. Five of them came from villages in Ruthenia, the sixth, now in Hradec Králové, came from the Rusyn village of Habura in the north-eastern corner of Slovakia.

${ }^{55}$ P.H. Mudry, "Kolonialna vystava," Sotatskii Russkii vîstnyk (26 April 1936), 2.
} 
could imagine that in Uzhhorod people wear turbans or a fez and that on the train platform they will dance La Bayadera for them. He just imagines something non-western and strange - that's the main thing. ${ }^{56}$

The suggestion that French visitors might expect to find the real Orient in Ruthenia reflects the exotic fantasy which Czech tourists hoped to see when they travelled to Ruthenia at that time.

Lecturers and adventurers with knowledge of Ruthenia travelled throughout the Bohemian lands giving presentations about their experiences among the Rusyn people. Advertisements for these events often used the term "Czechoslovak Orient" as a means of inspiring interest in the exotic character of Rusyns. In 1933 Hradec Králové newspaper Štít described a lecture with photographs of Ruthenia to be held in the regional town of Dvưr Králové nad Labem:

there will be a lecture and photo presentation titled 'Subcarpathian Ruthenia'. It will surely be an interesting event. 'The Czechoslovak Orient' is still a little known part of our republic, with the Hutsul way of life and magnificent images of nature. [...] Don't miss this opportunity to see our Rusyn brothers in their own native environment. ${ }^{57}$

Despite the assertion that the Rusyns were Slavic brothers, the offer to see them "in their own native environment" had the tone of a zoo inviting the public to see a new animal species on exhibit, and comparable to colonial exhibition practices across Europe at that time. ${ }^{58}$ A similar announcement, possibly for the same lecturer and photographs, appeared in Český deník in 1936 for an event which was to be held in Plzeň:

This Saturday at $8 \mathrm{pm}$ the local Sokol committee will host the lecture 'Subcarpathian Ruthenia' with beautiful photographs. The presenter lived in Subcarpathia for several years for research purposes. [...] For this reason, you shouldn't miss the opportunity to come and see Subcarpathian Ruthenia, our Orient. $^{59}$

Public interest in Ruthenia hinged on its status as the unknown corner of the republic, so those who attended such lectures would have come expecting to hear about a way of life which was as foreign as the Orient to them.

\footnotetext{
56 “Vizitez la Tchécoslovaquie!” Přitomnost (1 September 1937), 557.

57 “Dvůr Králové nad Labem,” Śtít (4 May 1933), 3.

${ }^{58}$ For an examination of human zoos and colonial exhibitions, see Sadiah Qureshi, Peoples on Parade: Exhibitions, Empire and Anthropology in Nineteenth-Century Britain (Chicago: University of Chicago Press, 2011).

59 “Do starého Plzence!” Český deník (27 March 1936), 6.
} 
The term "Czechoslovak Orient" also became a staple of the Czech tourism industry during the early 1930s. Following the stock market crash of 1929 and the worldwide economic crisis which followed, many previously wealthy Czechs found they were unable to afford holidays abroad as easily as they used to, so marketers presented Ruthenia to urban Czechs as an exotic, Oriental destination which could be visited cheaply without needing to leave the borders of the Czechoslovak state. The theme of "The Orient" appeared prominently in a tourism advertisement in Pestrý týden in 1935 which encouraged Czech visitors with such eye-catching slogans as "Subcarpathian Ruthenia - the Czechoslovak Orient," and "Subcarpathian Ruthenia, a land of peculiar people and unimaginable natural beauty is waiting for you. ${ }^{" 60}$ A similar tourism promotion in Český denik in 1936 encouraged Czech tourists to "come and see Subcarpathian Ruthenia, our Orient." ${ }^{, 11}$ Advertisements advised tourists to visit Ruthenia sooner rather than later since the "Oriental flavour" which gave the territory such an attractive air of mystique would soon be eradicated by Czech civilizing influences. In Pestrý týden in 1938 Jaromír Tomeček described Ruthenia as "the last outpost of the magical Orient" on the European continent, which "day by day is dissolving under the influence of western culture." Oriental fantasy land of Ruthenia developed further due to the popularity of Ivan Olbracht's 1933 novel Nikola Šuhaj loupežník [Nikola Šuhaj the Outlaw] which depicted Ruthenia as a place for fairytale adventures.

As Czech tourist visitors began arriving in Ruthenia with hopes of seeing an exotic land, their impressions were shaped by these preconceived Oriental expectations. In Z Užhorodu pěšky na Hoverlu [From Uzhhorod to Hoverla on Foot] Karel Kasalický reflected on how remote from the Bohemian lands he considered Ruthenia to be during his travels: "You will think that you are in an inhospitable and uncultured region, perhaps you will be reminded of Robinson Crusoe."63 In 1933 Národní listy published a first-hand account of a Czech tourist's experiences in Ruthenia, in which they described the lengthy train journey and frequent delays on the rail line from Prague to Iasinia/Jasiňa, the most eastern town in the Czechoslovak Republic. The train had

\footnotetext{
60 “Podkarpatská Rus - Československý Orient,” Pestrý týden (25 May 1935), 12.

61 “Do starého Plzence!" Český deník (27 March 1936), 6.

62 Jaromír Tomeček, "I na podzim je Podkarpatská Rus krásná,” Pestrý týden (3 September 1938), 5.

${ }^{63}$ Karel Kasalický, Z Užhorodu pěšky na Hoverlu (Uzhhorod: Státní tiskárny, 1928), 63.
} 
to pass through a section of Romanian territory before it arrived at its final destination in Iasinia, and the tourist referred to this train journey as a trip on "The Czechoslovak Orient Express.",64

The image of Oriental and primitive Ruthenia promoted for tourist consumption created expectations for visitors which the territory could not fulfill. As the most eastern town in the republic, Iasinia attracted many Czech visitors who came hoping to get a glimpse of the Czechoslovak Orient as it appeared in their imaginations. Czech author Stanislav Kostka Neumann described his travels in the eastern part of Ruthenia in 1933 and he noted the disappointment shown by Czech visitors when they arrived in the border town of Iasinia: "Tourists come expecting to see the Orient in 'the most eastern town in the republic', and they leave disappointed not to find it in this big village." ${ }^{, 65}$ As more Czech tourists visited Ruthenia and returned with first-hand knowledge the hazy image of the territory as an "Orient" became harder to sustain. A tourism announcement in 1936 in Národní politika suggested that Ruthenia had become civilized enough that it should lose its title of Czechoslovak Orient:

Our Subcarpathian Ruthenia, formerly considered by us Czechs to be a 'dark Orient', has started to become more accessible for visitors since the revolution. [...] In recent years it has even started to offer tourist 'comforts' [...] and the inhabitants are adapting to welcoming guests since it is profitable for them. ${ }^{66}$

The surprise shown by tourists to find that the reality they saw in Ruthenia did not match the fantasy they had expected reflects how deeply the region had been mythologized and misrepresented as an Oriental territory.

Accusations of Czech colonial practices in Ruthenia also came from Slovak nationalists and from foreign observers. The Slovak newspaper Národnie noviny claimed in 1927 that the Prague government considered Ruthenia to be their own colony and that the Czech media were complicit in spreading this opinion:

in the streets of the towns there are Czech signs on the buildings, Czech announcements, and so on, everything like in a Czech colony. [...] Newspapers in Prague and Brno accept and publish articles by Czechs in Subcarpathia in which they openly write about this region as if it were a Czech colony. ${ }^{67}$

\footnotetext{
64 “Povodeň se blíži,” Národní listy (14 July 1933), 4.

${ }^{65}$ Stanislav K. Neumann, Enciány s Popa Ivana (Prague: František Borový, 1933), 114.

66 “Několik poznámek pro letošního turistu," Národní politika (4 July 1936), 4.

67 "Pražský akt 22. Februára," Národnie noviny (2 March 1927), 1.
} 
Slovak criticism of Czech involvement in Ruthenia's administration stemmed from concerns about defending Slovakia's right to political autonomy in the face of centralization by the Prague government. A foreign accusation of Czech colonial rule came from British author C.A. Macartney in his 1937 book Hungary and Her Successors. He directly compared the behaviour of Czech officials in Uzhhorod with that of British colonizers:

In many respects the position of the Czechs in Ruthenia reminds the traveller strongly of that of the British in India. Uzhhorod's prosaic but efficient new quarter of Galago, built by the Czechs since the War to house the new army of civilian and military authorities, recalls the European compounds on the fringes of so many Asiatic cities; [...] It is true also that most of the Czech officials feel that they are living in a foreign land. They regard the Ruthenes as 'natives', and many of them sigh frankly enough for the day of retirement when they will be enabled to leave 'Asia' behind and settle down on their pensions at home in the Historic Lands. ${ }^{68}$

As a supporter of Hungarian revisionist interests Macartney perhaps had Magyar sentiments in mind, but his colonial analogy reflected the consequences of the lack of social mixing between Czech officials and the Rusyn intelligentsia. The Galago quarter in Uzhhorod and Little Galago in Khust/Chust, specially constructed to provide housing and office space for Czech officials, solidified this division into two separate social realms in Ruthenia's cities.

Metaphorical images of Ruthenia as a colony in darkest Africa or the exotic Orient appeared among both Czechs and Rusyns throughout the twenty year period of the territory's union with Czechoslovakia. A lack of general knowledge about the territory at the outset of the republic encouraged the Czech media to present it as a distant colonial outpost. Stereotypes of primitive behaviour among the Rusyn peasants led Czechs to question if it was truly possible for the territory to be considered European, Slavic and Christian. Once Ruthenia's status as a European territory could be questioned the next step of imagining Ruthenia as an overseas colony under Czech control was a simple progression. A desire to possess an overseas colony like West European nations was unconsciously superimposed onto Ruthenia through terms such as "The Czechoslovak Orient" which soon became absorbed into the Czech public consciousness.

${ }^{68}$ Macartney, Hungary and Her Successors, 226. 
The colonial metaphor generally divided into two categories, the African colony and the Oriental colony. "African Ruthenia" served to highlight the primitive cultural level and backwardness of the region and its inhabitants, while "Oriental Ruthenia" evoked both primitiveness and the exotic and mystical aspects of the territory in the Czech imagination. While the "African" label could only be considered negative in tone, the "Oriental" label could sometimes have more positive undertones; the Czech tourist industry seized on the image of the "Czechoslovak Orient" in the 1930 s as a means of promoting the territory. Czechs could also consider Ruthenia to be "half-Oriental" suggesting the territory could be Europeanized with enough Czech guidance. These colonial labels appeared in many forms of Czech media and popular culture, while for Rusyn intellectuals the colonial metaphor became a means of protest against the Prague government and local Czech officials. Use of colonial imagery by both Czechs and Rusyns to describe their relationship helped to build an imagined colonial space in which both sides contributed to the idea of a colonial power structure. As we shall see, Czech officials in Ruthenia played an important role in establishing the impression of Ruthenia as an imperial venture for the state. 


\section{Chapter 5}

\section{From Humanitarianism to Imperialism: Rusyn Views of František Svojše and Czech Officials in Ruthenia}

The establishment of a Czechoslovak administration for Ruthenia in 1919 began with claims of noble intentions. The Prague government expressed its wish to help a fellow Slavic nation stand on its own feet after centuries of Hungarian rule. With many Rusyns in need of basic necessities such as food and shelter, humanitarian aid became the first priority. At the same time there was an urgent need to establish order and secure Czechoslovakia's control in this far eastern territory of the republic. The collapse of Hungarian rule had left a legal vacuum, and the first Czechs who arrived in the region had to begin building a regional administration from scratch. The Treaty of St. Germain had stipulated that "officials in the country of the Ruthenians will be chosen as far as possible from the inhabitants of this territory,"1 but in practice Czechs filled nearly all positions of power. ${ }^{2}$ The Prague government argued that the small Rusyn intelligentsia had no experience in governing, and that a firm Czech hand would be needed to maintain stability while Hungarian irredentism and Bolshevism still loomed. Rusyns would have to undergo years of training and education before being ready to run the administration themselves.

Huge challenges in the post-war environment tested Czech resolve as they began to create a functioning civil administration in Ruthenia. Some of the local Rusyn intelligentsia were hostile towards their presence, and most Czech officials made little effort to learn the local language and engage in social contact with Rusyns. Rusyns complained of corruption and theft by Czech officials, particularly those working in the countryside, and Czech government reports confirmed that many officials had tried to profit from their positions. Low morale, hardship and isolation increased the challenges for Czech officials in the early years of their administration.

\footnotetext{
${ }^{1}$ From the text of the Saint Germain Treaty reproduced in Vincent Shandor, Carpatho-Ukraine in the Twentieth Century (Cambridge, Mass.: Harvard University Press, 1997), 23.

${ }^{2}$ Czechoslovak government statistics give the ethnicity "Czechoslovak" when referring to Czech and Slovak officials working in Ruthenia, though it can be safely assumed that Czechs composed the vast majority of those employed. Rusyn and Czech historical actors consistently refer to the officials in Ruthenia as "Czechs," and qualified Slovak officials were in demand to fill administrative positions in their own territory. Government statistics on the ethnicity of officials are provided in: Macartney, Hungary and Her Successors, 225.
} 
From the original aim of building unity with a fellow Slavic nation, a growing gap in trust and understanding developed between Czech officials and the Rusyn inhabitants.

Gendarme, journalist and publisher František Svojše became a figurehead of the perceived shift from Czech humanitarianism towards imperialism in Rusyn eyes. In their view, Czechs should only have come to Ruthenia to help Rusyns develop their culture and living standards, but such hopes faded as the officials grew comfortable in their positions of power. Svojše's promotion of Czechization in the administration and school system and contempt for the Rusyn intelligentsia confirmed for Rusyns that Slavic idealism had its limits. Forced to respond to stinging accusations of imperialism, Czech officials in Uzhhorod sought to reject the label of imperialist rulers. They promoted broader knowledge of the benefits Czechoslovakia had brought to the Rusyn territory, including improved infrastructure, public health and economic potential. The perceived drift towards imperialist behaviour would contribute significantly to the rise of the Rusyn autonomy movement in the late 1920s, and eventually to Czechoslovakia's loss of Ruthenia.

\section{In a Strange New Land}

The first significant numbers of Czech civilian bureaucrats began to arrive in Uzhhorod in August 1919. President Masaryk sent Jaromír Nečas, trained as a civil engineer, to be his representative and adviser during the transition period. ${ }^{3}$ During the establishment of Czechoslovak control the territory remained under the administration of French General Edmond Hennocque, who commanded Czechoslovak military forces until stability of the frontiers had been secured. ${ }^{4}$ In the final months of 1919 Czech legionaries still controlled only the western half of Ruthenia while Romanian soldiers occupied the region to the east of Mukacheve. ${ }^{5}$ As a result, arriving Czech officials set up operations in Uzhhorod since it lay in the region where they exercised the most control.

\footnotetext{
${ }^{3}$ Many of Nečas' reports for Masaryk have been preserved in the collection AKPR Fond PR.

4 “General Hennoque ministru národní obrany k 1 máji," Národní politika (3 May 1919), 2. Ruthenia would remain under military rule until January 1922.

${ }^{5}$ Magocsi, The Shaping of a National Identity, 91.
} 
The conditions which Czech officials experienced after stepping off the train in Ruthenia were unfamiliar and discouraging. Jaromír Nečas described the situation he saw there in 1919 as "challenging and dangerous." $\mathrm{He}$ felt the city's transport infrastructure needed immediate improvements, lamenting that the "roads were in a desperate state, and the railway lines were insufficient."7 Police official Antonín Veselý recalled that in the earliest days "every Czech official in Ruthenia was a pioneer, [...] in all the region there was uncertainty. [...] There wasn't enough wood, coal, bricks, lime or cement; everything had to be imported with great difficulty. [...] The city and its vicinity were infested with typhoid." ${ }^{8}$ The challenges they faced on a daily basis led several officials to describe their task in biblical terms. Karel Krrivanec, the first administrator for public works in Uzhhorod, recalled that their work in 1919 "began like the creation of the world, from nothing," "9 while an anonymous official interviewed in Podkarpatské hlasy recalled nostalgically that "In the beginning there was darkness, like the start of the bible; [...] Like biblical heroes we worked with a hammer in one hand, a sword in the other."10

The first small group of officials to arrive in Ruthenia had to work together to succeed in their new environment. In the beginning "all the administration of Ruthenia occurred daily around a long dining table in the Hotel Berecseny in Uzhhorod," ${ }^{11}$ and those who were part of this first group described a wonderful sense of camaraderie. Nečas recalled that he and the other officials had "bonded socially among ourselves in Uzhhorod, due to the dangers we faced and the fact that we had to depend on each other,"12 while the anonymous official interviewed in Podkarpatské hlasy referred to the year 1919 as "a golden age, with friendships regardless of title... we didn't have one hour for our own lives."13 Many of those who first arrived in 1919 believed that the Czech presence in Ruthenia and the territory's inclusion in Czechoslovakia

\footnotetext{
${ }^{6}$ Jaromír Nečas, “Začátky státní technické služby,” in Vzpomínky průkopníků technické služby v zemi Podkarpatoruské (Uzhhorod: Státní tiskárny, 1933), 3-4.

${ }^{7}$ Nečas, "Začátky státní technické služby," 3-4.

${ }^{8}$ Antonín Veselý, "Užhorodské vzpomínky kolem r. 1920," in Vzpomínky průkopníků technické služby v zemi Podkarpatoruské (Uzhhorod: Státní tiskárny, 1933), 16-21.

${ }^{9}$ Karel Křivanec, “Začátky referátu veřejných prací," in Vzpomínky průkopniků technické služby v zemi Podkarpatoruské (Uzhhorod: Státní tiskárny, 1933), 5-6.

10 "Na počátku byla tma...," Podkarpatské hlasy (28 October 1928), 3.

11 "Na počátku byla tma...," Podkarpatské hlasy (28 October 1928), 3.

12 Nečas, "Začátky státní technické služby," 3-4.

13 "Na počátku byla tma...," Podkarpatské hlasy (28 October 1928), 3.
} 
might only be temporary, due to the fluid nature of political developments in Bolshevik Hungary and the Ukrainian territories. ${ }^{14}$

The reasons why Czechs agreed to go east to work in Ruthenia varied, with some drawn by a sense of adventure, others by humanitarian motives, the possibility of earning a good salary in a government job, or in some cases because they could find no other employment as an official in the Bohemian lands. ${ }^{15}$ Many officials considered their role in Ruthenia to be a high and worthy cause, assisting the poor and neglected Rusyn people. The anonymous official in Podkarpatské hlasy described their actions in the earliest period as a selfless act of caring: "The first concern of the Czechoslovak administration was people's suffering, they worked here for a beautiful ideal $[\ldots]$ risking their health and life daily for an unknown land which was neglected and poor, for an illiterate nation which had degenerated under the Hungarian 'master'."16 Karel Krrivanec described his decision to go to Ruthenia as a welcome challenge for his organizational abilities: "To go to a territory which was fully unknown to me was a great personal sacrifice. [...] Here I saw ahead of me a field waiting for a diligent ploughman, for me it was like being given a blank white sheet of paper on which I had to write the first lines."17 Such great responsibility meant the future of the Rusyn people was truly in their hands; Czech daily Tribuna felt that stability in Ruthenia "stands or falls at any given moment with the Czech officials." 18

Many of the Czech gendarmes and officials who came to Ruthenia had previously worked as administrators in other regions of the Austro-Hungarian Empire during its final years, particularly in the territory of Bosnia and Herzegovina. Some of these officials were packed onto trains and transported directly to Uzhhorod from their previous Bosnian assignment. ${ }^{19}$ Jan Liewald, a Czech gendarme who went by train from Mostar to Uzhhorod in 1920, described how he and his companions had first learned about Ruthenia before their transfer:

Uzhhorod - yes, we had heard of it, but I had forgotten where it was. In Subcarpathian Ruthenia? We really didn't know anything about it, and we

\footnotetext{
14 “Systematisace úřednických míst v Rusínsku,” Tribuna (22 October 1920), 2.

${ }^{15}$ D. Mecher, "Politické poměry v Podkarpatské Rusi," Report for the Interior Ministry, 10 December 1921. AÚ TGM Fond TGM-R, carton 400.

16 "Na počátku byla tma...," Podkarpatské hlasy (28 October 1928), 3.

${ }^{17}$ Křivanec, "Začátky referátu veřejných prací," 5-6.

18 “Systematisace úřednických míst v Rusínsku," Tribuna (22 October 1920), 2.

19 Jan Liewald, “Z Mostaru do Užhorodu v roce 1920," in Vzpomínky průkopníků technické služby v zemi Podkarpatoruské (Uzhhorod: Státní tiskárny, 1933), 22.
} 
couldn't find it in an atlas. An explanation came to us by chance in an issue of Czech World in an article about Ruthenia. The opening words didn't cheer us much: 'The darkest corner of our republic is Subcarpathian Ruthenia., 20

The sixteen-day journey by train to Uzhhorod didn't bother him, for he claimed "we weren't in a hurry, because we had spent happy years living in Bosnia and Herzegovina and Ruthenia didn't hold much promise as 'the darkest corner of our republic'."21 Although Liewald and his companions knew little about what awaited them in Ruthenia, their Bosnian experiences helped them to adapt to the new environment more readily than those who came directly from the Bohemian lands.

The uncomfortable living conditions in Ruthenia would prove to be one of the biggest drawbacks for the officials who arrived in the first few years of the new republic. Antonín Veselý recalled that accommodation was so limited that when they first arrived in Uzhhorod "many new arrivals had to stay in the train station." 22 Writing to President Masaryk, Nečas reported that the living conditions for Czech officials had to be improved: "Unmarried people sleep in their offices, married people with families are crammed into totally inadequate premises (often with the whole family in one small room), yet they still pay a lot of money for such small and unclean accommodation." 23 Vice-governor Ehrenfeld, appointed in February 1920, made building new accommodation for officials a priority upon assuming the office: "I am working hard in this regard; we are building wooden houses ourselves, so that this year at least 70 families will finally have housing with two rooms and a kitchen." ${ }^{24}$ Ehrenfeld recognized the important correlation between the quality of housing for officials and their morale for working in the new environment.

Some officials found the hardships too difficult and wished to return to the familiar comforts of the Bohemian lands. Czech publication Tribuna reported that the "Flight of Czech officials from Ruthenia seriously endangers the entire administration of the territory," and felt more had to be done to retain skilled officials. ${ }^{25}$ Conditions in the villages and small towns were especially difficult, and the younger gendarmes and notaries without families were often left

\footnotetext{
${ }^{20}$ Liewald, "Z Mostaru do Užhorodu v roce 1920," 22-23.

${ }^{21}$ Liewald, "Z Mostaru do Užhorodu v roce 1920," 30.

${ }^{22}$ Veselý, "Užhorodské vzpomínky kolem r. 1920," 16-21.

23 Jaromír Nečas, Report for President T.G. Masaryk, 18 August 1921. AÚ TGM Fond TGM-R, carton 401.

${ }^{24}$ Petr Ehrenfeld, Report for the Interior Ministry, 26 August 1920. AÚ TGM Fond TGM-R, carton 400.

25 “Systematisace úřrednických míst v Rusínsku," Tribuna (22 October 1920), 2.
} 
longing for other Czechs for companionship. Karel Křivanec spoke of the hardships and isolation he endured: "We often felt cut off from the whole world, lacking both letters and news and left to rely only on ourselves. ${ }^{26}$ Tribuna stressed the lack of culture available to Czechs posted in the countryside: “A Rusyn doesn't have such cultural needs as our mentally mature officials, who are in many places completely isolated from higher forms of culture, especially native Czech culture. ${ }^{27}$ Jaroslav Zatloukal wrote of the need to put time limits on the service of Czechs in the territory: "Because the position of Czechs in this land is difficult and grueling, especially the gendarmes and border guards in total wilderness, it is necessary to take into account their period of stay and grant requests for transfer. Otherwise depression and dissatisfaction will develop among them." 28

Some of those who came to take up official positions as gendarmes or notaries in the regions saw opportunities for personal profit, through both legal and illegal means. State inspector D. Mecher reported that when recruiting officials for the new territory, "the people who willingly come to Ruthenia do so because it is more profitable, they are only trying to get rich." 29 Vice-governor Ehrenfeld admitted that Ruthenia attracted officials who were prepared to abuse their positions for profit: "There are many officials in the ranks which I would rather not have here. Many officials wanted to come here only so that they could earn money and then go back again. Unfortunately there are ample opportunities for such activities here, and recently I have had to intervene six times and they were sentenced in court. ${ }^{" 30}$ Common offenders were usually notaries and gendarmes at the village level where government scrutiny of daily activities was minimal. ${ }^{31}$ National Democratic Party organ Podkarpatská Rus described how this symbiotic process of corruption occurred: "The gendarmes, who have firm control over the Rusyns, are often fully aware of despotism among the notaries, yet about this they remain cautiously silent

\footnotetext{
${ }^{26}$ Křivanec, "Začátky referátu veřejných prací," 14.

27 “Systematisace úřednických míst v Rusínsku," Tribuna (22 October 1920), 2.

28 Jaroslav Zatloukal, “Za hlubším a objektivním poznáním Podkarpatské Rusi,” in Podkarpatská Rus (Bratislava: Klub přátel Podkarpatské Rusi, 1936), 11-12.

29 “Politické poměry v Podkarpatské Rusi,” Interior Ministry report by inspector D. Mecher, December 1921. AÚ TGM Fond TGM-R, carton 400.

${ }^{30}$ Petr Ehrenfeld, Report for the Interior Ministry, 26 August 1920. AÚ TGM Fond TGM-R, carton 400.

${ }^{31}$ Petr Ehrenfeld, Report for the Interior Ministry, 26 August 1920. AÚ TGM Fond TGM-R, carton 400.
} 
like diplomats. ${ }^{, 32}$ In an environment of disorder where regional officials were left to take care of themselves, corruption and financial fraud spread quickly.

By the summer of 1920, Rusyn complaints about corrupt Czech officials in their towns and villages became known in Prague. An Interior Ministry report from this period summarized government concerns about the illegal activity: "There are many complaints against officials. In the Czech administration our Czech people are accused of negligence and bribery. It is thought that people in certain locations 'made' a great deal of money after a short period of time."33 Numerous Czechoslovak Interior Ministry reports bear out the truth in the corruption accusations made by Rusyns. Writing to the Interior Ministry, vice-governor Ehrenfeld listed the names and crimes of notaries arrested since the beginning of 1920, mostly for embezzlement of funds, fraud and abuse of office. ${ }^{34}$ He worried about the negative impact such behaviour was having on relations with the Rusyn people: "It is unfortunately true that the people complain about Czech officials. [...] I always say that one bad official can cause so much evil here that the greater number of good officials will be unable to repair the damage caused." 35 National Democratic Party organ Podkarpatská Rus, perhaps seeking to score points against the ruling Agrarian party, hinted at a government cover-up: "Sadder still is when we see that an official investigation held after complaints by local inhabitants avoided any mention of these realities."36

Rusyns began to question whether the Czech officials living among them could be trusted once examples of corruption came to light. Inspector D. Mecher reported to the Interior Ministry in 1921 about Rusyn dissatisfaction: "there are complaints that our officials in Ruthenia are not up to the task; $[\ldots]$ they complain that the people are not qualified, that in Bohemia and Moravia they would not be accepted." ${ }^{37}$ Ukrainophile Rusyn newspaper Rus'ka nyva expressed this sense of growing distrust and anger towards the officials in 1921:

In every nation, even in the Czech nation, there are different types of people, honest and dishonest. Many Czech officials came to Ruthenia for the purpose of exploitation, and when they arrived a very sad impression was made on our

\footnotetext{
32 “Kde jsou mezi služební horlivosti?” Podkarpatská Rus (19 March 1927), 3-4.

${ }^{33}$ Uzhhorod Administration Report for the Interior Ministry, 6 August 1920. AÚ TGM Fond TGM-R, carton 400.

${ }^{34}$ Petr Ehrenfeld, Report for the Interior Ministry, 26 August 1920. AÚ TGM Fond TGM-R, carton 400.

${ }^{35}$ Petr Ehrenfeld, Report for the Interior Ministry, 26 August 1920. AÚ TGM Fond TGM-R, carton 400.

36 “Kde jsou mezi služební horlivosti?," Podkarpatská Rus (19 March 1927), 3-4.

${ }^{37}$ D. Mecher, Interior Ministry report “Politické poměry v Podkarpatské Rusi," December 1921. AÚ TGM Fond TGM-R, carton 400 .
} 
nation. We know and we have already noted many times that these people are like vermin in Ruthenia. ${ }^{38}$

The loss of trust in Czech officials was a worrying trend for the Prague government, as they feared greater instability and irredentism. An Interior Ministry report expressed concern over the deterioration of relations with the local Rusyns: "The current state of affairs in Ruthenia is impossible. The inhabitants not only don't have faith in the government in Uzhhorod, they even hate it, since it has already disappointed them so many times." 39

The Rusyn peasantry also expressed a lack of respect for the local Czech officials and gendarmes in their villages. Vice-governor Ehrenfeld wrote of the lack of support for the Czech administration among the Rusyn general population in 1922, claiming that Rusyns "demanded order" and felt freedom had brought them only chaos: "For instance, people publically say that the officials aren't able to do anything against them, that Czechs are their brothers, while Hungarians were the masters whom they had to obey." 40 British traveller Henry Baerlein also observed this characteristic during his visit to the Rusyn highlands in the early 1920s. While driving in a carriage with a regional Czech official, he noted that the Rusyn villagers "stood up as we drove past and saluted the deputy-magistrate. But they did not cringe. To be under the Czechs [...] was altogether different from the old subjection." The deputy magistrate then told Baerlein that Czechs were not given the same respect as the previous Hungarian masters: "I have heard them say that our gendarmes are no real gendarmes, because they refrain from flogging the people, as the Hungarians used to do."

Direct personal contact with corrupt or disrespectful Czech officials left a very negative impression on Rusyns. An inhabitant of Velykyi Bychkiv, a town on the border with Romania, wrote to Rusyn newspaper Karpato-Russkii vîstnyk to complain about corruption and discrimination shown towards him by Czech border guards:

Here at the border they live in paradise, bringing cheap food and products across the border from Romania for themselves, but if you - poor Rusyn - are carrying something across the border for yourself and your family the border

\footnotetext{
${ }^{38}$ Petr Ehrenfeld, “Článek 'Ruské nivy',” Report for the Presidential Office, 19 March 1921. Document PR $258 / 21$. AKPR Fond PR, carton 3.

${ }^{39}$ A. Novotný, Report for the Interior Ministry, 26 April 1921. AÚ TGM Fond TGM-R, carton 401.

${ }^{40}$ Included in a personal letter from Petr Ehrenfeld to Přemysl Šámal, head of the Presidential Office of the Republic, 1 March 1922. AÚ TGM Fond TGM-R, carton 401.

${ }^{41}$ Baerlein, Over the Hills of Ruthenia, 23.
} 
guards shout 'Not Allowed!' They call you a smuggler, they confiscate everything and then beat you until you are bleeding. ${ }^{42}$

Such unpleasant encounters did not match the images of brotherly love and Slavic unity which Rusyns had hoped for in 1919, and they could see that Czechs did not consider them as equals in the republic. The growing sense of hatred towards Czech officials and such overt accusations of imperialism in Rusyn publications led to hand-wringing in Prague and Uzhhorod. Vice-governor Ehrenfeld confirmed for the Interior Ministry just how low relations with Rusyns had sunk by 1922: "It is possible to say that a significant part of the local Rusyn intelligentsia show no love towards our republic and towards the Czech nation. [...] [It is] said that Czechs are here only as guests and that after 1000 years Hungarians failed to conquer them and the Czech nation will not succeed in doing so during the next 1000 years." 43

Popular contempt for Czech officials naturally led to discussions about how to improve relations with the population in Ruthenia. Jaromír Nečas felt that one factor above all others made developing a trustworthy relationship with the Rusyns difficult:

There is one significant mistake for which nearly all Czech officials can be criticized. They do not learn the mother tongue of the people and this separates and closes them off from the local intelligentsia and the people. This is a very significant mistake, because the people do not have full confidence in those who cannot speak their mother tongue. ${ }^{44}$

Little progress occurred in the area of Rusyn language skills, since Nečas had to reiterate the urgent need for officials to learn Rusyn when writing to Masaryk six years later: "A big mistake made by Czech officials in Ruthenia is that they don't learn the local language. [...] Czech people speak to them in a related language but still a foreign one." 45 Nečas also felt that Czech officials had to do more to connect socially with Rusyns in order to bring their divided communities together: "in the towns they gather in their clubs, sokols and other groups, they speak Czech among themselves, office paperwork is also in Czech, so they live in Ruthenia like a foreign element." ${ }^{46}$ British scholar C.A. Macartney made similar observations: "The Czechs are not only a ruling class, but also a foreign one. They have their own clubs and coffee-houses,

\footnotetext{
42 “Afrykansky Poriadky,” Karpato-Russkii vîstnyk (21 January 1923), 10-11.

${ }^{43}$ Petr Ehrenfeld, Report for the Interior Ministry, 17 February 1922. AÚ TGM Fond TGM-R, carton 401.

${ }^{44}$ Jaromír Nečas, Report for President T.G. Masaryk, 18 August 1921. AÚ TGM Fond TGM-R, carton 401.

45 Jaromír Nečas, "Úřednictvo na Podkarpatské Rusi," Draft Report for the Czechoslovak Interior Ministry, 1927. AÚ TGM Fond TGM-R, carton 401, file Nečas - Referat o Podkarpatské Rusi, part A, section 5.

46 Jaromír Nečas, Report for President T.G. Masaryk, 18 August 1921. AÚ TGM Fond TGM-R, carton 401.
} 
patronize, to a large extent, their own shops, and mingle little with the natives, except to order their destinies." 47 In order to improve relations Nečas recommended two clear policy changes to President Masaryk, firstly to make learning Rusyn mandatory with testing, and to promote "closer interactions between officials and the local inhabitants in non-official contexts."48

In response to growing anti-republic sentiment in Ruthenia, the Uzhhorod administration introduced a system of surveillance of Rusyn political parties and their publications. Censorship of the Rusyn press increased, with entire articles sometimes removed in anti-government publications such as Kurtiak's Russkii vîstnyk and Gagatko's Russkaia zemlia. ${ }^{49}$ Officials in Uzhhorod collected and translated any irredentist or anti-Czech publications and sent them to the Interior Ministry in Prague for thorough risk analysis. ${ }^{50}$ For example, when Ukrainophile Rus'ka nyva referred to Czech officials as "vermin in Ruthenia" in 1921, the Interior Ministry launched an investigation to discover who had written the anonymous piece. ${ }^{51}$ Gendarmes carefully watched the day-to-day movements and social interactions of Rusyn leaders, particularly Kurtiak and Russophiles such as Gagatko. ${ }^{52}$ Czech notaries attended the public meetings held by Rusyn political parties in villages throughout the territory, and they transcribed the speeches and discussions for analysis by the Interior Ministry. ${ }^{53}$ Local gendarmes also had the power to call off Rusyn public meetings if speakers expressed anti-republic sentiment. For instance, when a party member shouted "Czechs are our enemies" during a public meeting of the Carpatho-Rusyn Labour Party, the gendarme sprang into action: "I gave them a strong warning that the rest of the meeting would be cancelled. The speaker took note of the announcement and withdrew as he didn't want to cause the cancellation of the session. In the speeches which followed the tone was suitably changed."54

\footnotetext{
${ }^{47}$ Macartney, Hungary and Her Successors, 226.

48 Jaromír Nečas, Report for President T.G. Masaryk, 18 August 1921. AÚ TGM Fond TGM-R, carton 401.

${ }^{49}$ For examples of fully censored articles see Russkaia zemlia (19 June 1920), 2; and Russkaia zemlia (9 February 1922), 2.

${ }^{50}$ Hundreds of such reports about Rusyn publications are available in the collections of AKPR Fond PR.

${ }^{51}$ Petr Ehrenfeld, “Článek 'Ruské nivy',” Report for the Presidential Office, 19 March 1921. Document PR $258 / 21$. AKPR Fond PR, carton 3.

${ }^{52}$ Many surveillance reports about Rusyn leaders exist in the collections of AKPR Fond PR.

${ }^{53}$ Examples of transcriptions of Rusyn political party meetings sent for analysis exist in AKPR Fond PR.

${ }^{54}$ František Velichovský, regional official for the town of Velký Sevljuš, Report prepared for the Civil Administration of Ruthenia and the Interior Ministry about a meeting of the Carpatho-Rusyn Labour Party in the village of Mali Kopani, 27 May 1927. AKPR Fond PR, carton 9, document 280/27.
} 
Increasing levels of anti-Czech agitation led to concerns about the personal safety of Czechs and their families living in Ruthenia. Nečas reported to President Masaryk that many officials worried about what would happen in the event of an uprising against them: "Among the officials, especially those who are married, there is concern for the future because of the instability of affairs, unrest and agitation. [...] Their fear of a revolution is understandable due to the manner of the agitation for autonomy, in which Czech officials are directly bombarded with hatred. ${ }^{, 55}$ By 1921 there were already almost 20,000 Czechs living and working in different regions of Ruthenia and protecting them in the event of an open revolt would be an enormous challenge. ${ }^{56}$ To maintain order, Nečas felt that the government must be ready to act against "all visible and invisible enemies of the republic," while A. Novotný suggested to the Interior Ministry that "placing Czech legionaries from Russia here would bring positive results." 57 The decision to offer land in Ruthenia to Czech legionaries as settler colonists may have resulted partly from these concerns about anti-republic and irredentist behaviour.

Although the general atmosphere in Ruthenia seemed hostile, not all Czech officials described their relations with Rusyns in a negative fashion. Antonín Veselý wrote of the warm connections he had with Rusyns in the early 1920s and their loyalty to the republic: "Some of the local inhabitants became friends with us, which even led to social contact with them. When the President visited Uzhhorod, all the inhabitants were in the street to jubilantly welcome him. ${ }^{, 58}$ Some Rusyns idolized President Masaryk as a symbol of the Slavic unity they had expected from Prague, while simultaneously distrusting the Czech officials in their midst. ${ }^{59}$ Nečas drew attention to the small number of Czech officials in Uzhhorod whom Rusyns did not hold in contempt: "There are a few small exceptions which are positive. In particular, some individual officials have gained great respect for their efforts in the development of the territory, [such as] school inspector Pešek, financial manager Kugler, court judge Křepinský, and social care worker Polák." ${ }^{60}$ School inspector Pešek received praise from Ukrainophiles but was distrusted by

\footnotetext{
${ }_{55}^{5}$ Jaromír Nečas, Report for President T.G. Masaryk, 18 August 1921. AÚ TGM Fond TGM-R, carton 401.

${ }^{56}$ Jaromír Nečas, Report for President T.G. Masaryk, 18 August 1921. AÚ TGM Fond TGM-R, carton 401.

${ }^{57}$ A. Novotný, Report for the Interior Ministry, 26 April 1921. AÚ TGM Fond TGM-R, carton 401.

${ }^{58}$ Veselý, "Užhorodské vzpomínky kolem r. 1920,” 16-21.

${ }^{59}$ Jevgenij Nedzielskij, T.G. Masaryk v Podkarpatoruském Basničtví (Bratislava: Podkarpatoruské nakladatelství, 1937). The Rusyn peasantry also had a history of showing great respect for the Austrian monarch while fearing the local Hungarian officials in their region.

${ }^{60}$ Jaromír Nečas, Report for President T.G. Masaryk, 18 August 1921. AÚ TGM Fond TGM-R, carton 401.
} 
Russophiles because he favoured a Ukrainian orientation for the language of study in Rusyn schools. $^{61}$

Vice-governor Ehrenfeld received praise from both Russophiles and Ukrainophiles, though his preference for the Ukrainophile cultural orientation ensured Ukrainophile intellectuals remained more loyal to him during his time in office. Jaromír Nečas wrote of the high esteem Rusyns had for the vice-governor:

Ehrenfeld enjoys respect and dignity for his objectivity, exceptional work ethic, and accommodating manner with the people. [...] He often goes among the people, where he has developed a comprehensive knowledge of the region. He has already learned Rusyn and he is learning Hungarian. The inhabitants of Ruthenia in the cities and towns are very impressed by these characteristics, because they weren't accustomed to such behaviour from high officials during the Hungarian regime. ${ }^{62}$

Ukrainophile publication Rus'ka nyva felt Ehrenfeld was a capable administrator and an asset for Ruthenia: "We thank the Prague government for selecting such a man as Petr Ehrenfeld for the position of vice-governor, for he is enlightened and sensible." ${ }^{\text {, } 3}$ Rusyns may have approved of Ehrenfeld as the top Czech official in their territory, but Czech and Slovak officials in Ruthenia did not necessarily agree with his policies. Inspector D. Mecher informed the Interior Ministry that some officials privately disapproved of Ehrenfeld's leadership: "In local Czech and Slovak circles they say that Governor Ehrenfeld is weak, that his 'hands off' political approach gives too much freedom to subversive elements and Hungarian agitators."

The Interior Ministry decided to remove Ehrenfeld from the vice-governor position in August 1923, and in his place appointed Antonín Rozsypal. ${ }^{65}$ This occurred simultaneously with the appointment of Rusyn Antonii Beskid as Ruthenia's governor, a post which had remained vacant since the resignation and departure of Gregory Zhatkovych in 1921. The most significant aspect of this appointment was that Rozsypal and Beskid supported the Russophile cultural and

\footnotetext{
61 “Avtonomiia nashei shkolŷ,” Russkaia zemlia (14 April 1921), 2.

62 Jaromír Nečas, Report for President T.G. Masaryk, 18 August 1921. AÚ TGM Fond TGM-R, carton 401.

${ }^{63}$ Petr Ehrenfeld, "Článek 'Ruské nivy'," Report for the Presidential Office, 19 March 1921. Document PR $258 / 21$. AKPR Fond PR, carton 3.

${ }^{64}$ D. Mecher, Interior Ministry report “Politické poměry v Podkarpatské Rusi,” December 1921. AÚ TGM Fond TGM-R, carton 400.

65 “D-r Petro Erenfeld,” Rus'ka nyva (29 November 1923), 1.
} 
linguistic orientation, whereas Ehrenfeld had backed the Ukrainophiles. ${ }^{66}$ The shift in policy alienated leading Ukrainophiles such as Voloshyn, who considered the turn towards Russophilism following Rozsypal's appointment to be a sign of Czech betrayal. ${ }^{67}$ This decision would have significant consequences during the next few years as the autonomy movement gained ground among Ukrainophiles. While the move pleased Russophiles, Rusynophiles and autonomists such as Kurtiak still remained firmly opposed to cooperating with the government. ${ }^{68}$

The first Czechoslovak state elections held in Ruthenia in 1924 resulted in antiCzechoslovak parties winning a majority of the vote. The Ruthenian branch of the Communist Party received the greatest share of the vote at 39\%, while the ruling Agrarian party received $6 \% .{ }^{69}$ Responding to the anti-republic results in the election, Czech newspaper 28 řijen blamed the behaviour of Czech officials: "One of the causes of the poor judgement of the inhabitants is certainly the unsuitable administration which we have introduced in Ruthenia, and the poor morals of our officials at the beginning of our administration, which still has not been completely cured. ${ }^{, 70}$ Prime Minister Antonín Švehla and his Agrarian party were dismayed at the antirepublic sentiment the results represented, and in response he sent several well-trained young Agrarians to build the party's standing in Ruthenia. Among those dispatched to the east was Jan Brandejs, who would become an important figure in the Uzhhorod administration with responsibility for agriculture. ${ }^{71}$

Czech authors and journalists outside Ruthenia often overlooked the increasingly troubled relationship with Rusyns and continued to spread an image of Czech officials as humanitarian caregivers. Writing in 1924, Karel Matoušek described the work of the officials as a noble cause in a formerly backwards region:

Czech officials in Ruthenia have carried out a significant and worthy task. We have established this territory, turned the tyrannical Hungarian regime into Czechoslovak justice and democracy, improved communications, reestablished respect for the law. We are gradually bringing order to this land of

\footnotetext{
66 “Chekhy proty 'Prosvity'," Rus'ka nyva (20 December 1923), 2.

${ }^{67}$ Avhustyn Voloshyn, “Župní novela a Podkarpatská Rus,” Lidové listy (16 February 1927), ANM Fond Starý, carton 1 .

68 "Iak uriady vystupaiut' proty nas," Vpered (18 January 1924), 1.

69 "Rezul'tatŷ vŷborov v Karpatskoi Rusy," Russkaia zemlia (20 March 1924), 1.

70 “Češi v Podkarpatské Rusi,” 28 ř́jen (26 March 1924), ANM Fond Starý, carton 1.

71 “Ještě k otázce urbariální úpravy,” Podkarpatské hlasy (25 February 1936), 2.
} 
former Oriental disorder and confusion, along with discipline and west European democracy and culture. ${ }^{72}$

Matoušek spoke of the "true Slavism" and "honesty and efficiency" shown by Czech officials, while completely avoiding mention of the scandals and ongoing unrest. ${ }^{73}$ An Interior Ministry report for the League of Nations in 1928 also tried to suggest Rusyns had been grateful for Czech help in the early years of the republic: "Ruthenia provides overwhelming evidence that the inhabitants were indebted and still today are indebted to Czech officials for the difficult and successful work which they did in 1919 and 1920. [...] Today it is possible to say with a clear conscience that the officials are good." ${ }^{, 74}$ Such examples gloss over the undesirable aspects of the Czech administration in order to present the appearance of a happily united republic. Maintaining this image would only become more difficult as the Rusyn autonomy movement gained strength during the second half of the 1920s.

\section{František Svojše as a Symbol of Czech Imperialism}

Among the Czech gendarmes transferred from Bosnia to Ruthenia, one went on to play a high-profile role in relations with the Rusyn people. Svojše started as a gendarme captain when he arrived in Ruthenia and later rose to the position of head administrator for the state press service in Uzhhorod. ${ }^{75}$ In January 1925 he became a lightning rod for Rusyn anger against Czech officials when he began publishing his own newspaper, Podkarpatské hlasy, which attacked the Rusyn intelligentsia and promoted Czech superiority and Czechization for a reading audience of Czech officials. The newspaper's mandate, written below the header in every issue, declared Podkarpatské hlasy's purpose to be "defending the interests of Czech people in Ruthenia and Eastern Slovakia." ${ }^{76}$ In the editorial of the debut issue, Svojše cast Czech officials as a beacon of civilization in a land of darkness: "Today in the east of the republic dawn is coming, the Carpathian peaks are already illuminated with the brightness of knowledge and there, where the goal of our pilgrimage was once lost in the dark, now there is light. And with this light let us

\footnotetext{
${ }^{72}$ Matoušek, Podkarpatská Rus, 207.

${ }^{73}$ Matoušek, Podkarpatská Rus, 207.

${ }^{74}$ Czechoslovak Interior Ministry document Informace pro společnost národů o autonomii pro Podkarpatskou Rus, document no. 39894/1928, 18 June 1928. AÚ TGM Fond TGM-R, carton 403.

75 “Bojovníci proti 'Přŕšerné reakci',' Štit (23 February 1928), 7.

76 “Náš směr,” Podkarpatské hlasy (3 January 1925), 1.
} 
lead!"77 Svojše repeatedly contrasted such images of Czech superiority against images of Rusyn inferiority; many issues of Podkarpatské hlasy in 1925 and 1926 included cartoons depicting Czech surprise and shock at the infantile, drunken or uneducated behaviour of Rusyns. ${ }^{78}$

\section{Figure 5.1 - František Svojše Endorsing an Uzhhorod Suitcase Retailer (1926) ${ }^{79}$}

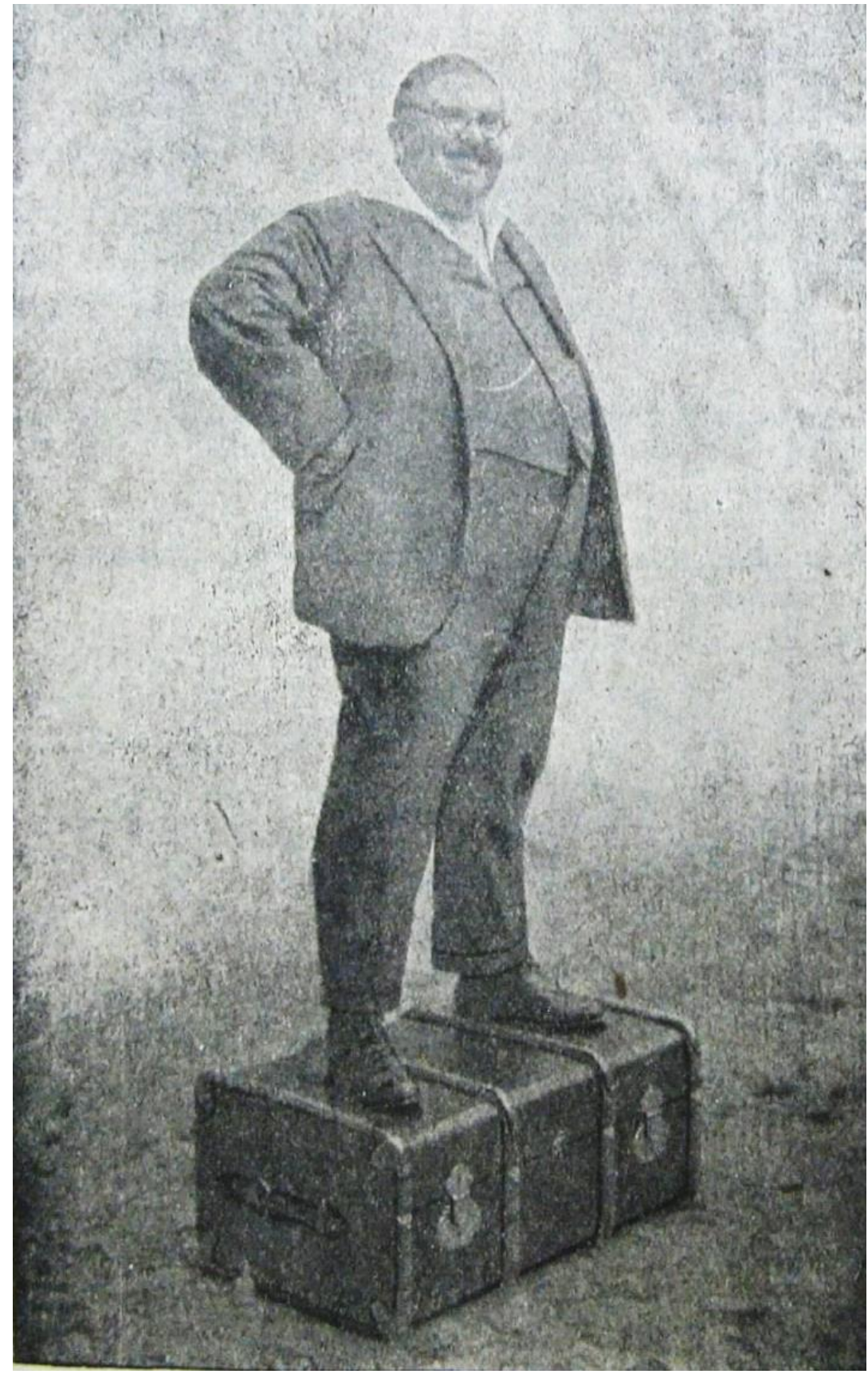

77 "Náš směr," Podkarpatské hlasy (3 January 1925), 1.

${ }_{78}^{78}$ See figures 3.1, 3.2 and 3.3 discussed in Chapter 3 for examples of these cartoons.

${ }^{79}$ Podkarpatské hlasy (5 June 1926), 3. Photograph by the author. 
From the outset Svojše declared that "our first enemy is the local intelligentsia," and constant friction with Russophiles and Ukrainophiles marked the first years of Podkarpatské hlasy's publication. ${ }^{80}$ Svojše considered the intelligentsia to be an obstacle to development in the territory, and saw Rusyn autonomy as a danger to Czech progress. As a result he promoted the construction of Czech schools in Rusyn villages as a means of gradually achieving linguistic and cultural assimilation. ${ }^{81}$ To further those aims he advocated the adoption of the Latin script (using Czechoslovak orthography) for the Rusyn language rather than the traditional Cyrillic. ${ }^{82} \mathrm{He}$ claimed that this would improve communication between Czechs and Rusyns, but the Rusyn intelligentsia saw his enthusiasm for a Czechoslovak Latin script as a further step towards their assimilation. ${ }^{83}$ Czech-language National Democrat publication Podkarpatská Rus condemned Svojše's slogan “Out with Cyrillic, it must disappear from Ruthenia!” as a dangerous form of Czechization, and called on the Rusyn intelligentsia to "battle against the impact of Svojše." 84

Rusyns quickly rallied to show their opposition to the publication of Podkarpatské hlasy, with Russophiles, Rusynophiles and Ukrainophiles presenting an uncommonly united position. Svobodnoe slovo responded to Svojše's attacks on the intelligentsia by confirming that they were indeed his enemy: "It's true, true, little Mussolini! After your vicious attacks on the Rusyn intelligentsia you are hated by all of them." ${ }^{85}$ Russophile Russkaia zemlia declared that Svojše represented nothing less than "the rapid Czechization of Subcarpathian Ruthenia, starting with the school system," 86 while Ukrainophile Vpered bluntly stated that "Podkarpatské hlasy is in the service of Czechization of Rusyns." ${ }^{, 87}$ Russophile leader Gagatko protested that state laws prohibited media publications owned by government officials, but Svojše had left his position as head of the state press service after founding Podkarpatské hlasy, and could claim that his editorials represented the voice of a private citizen. ${ }^{88}$

\footnotetext{
80 “Naši největší nepřátelé,” Podkarpatské hlasy (10 January 1925), 1.

81 “Naši největší nepřátelé," Podkarpatské hlasy (10 January 1925), 1.

82 “P. Hlasy proti kyrilici a pravoslaví,” Podkarpatské hlasy (30 March 1926), 1.

83 "Pochopit pravou slovanskou politika," Podkarpatská Rus (30 January 1926), 2.

84 "Pochopit pravou slovanskou politika," Podkarpatská Rus (30 January 1926), 2.

85 "Cheshskaia iumorystycheskaia hazeta 'Podkarpatske hlasŷ'," Svobodnoe slovo (19 February 1925), 2.

86 “Institut ohlupieniia ili Russkaia shkola?” Russkaia zemlia (26 February 1925), 1.

87 ““Podkarpat. Hlasy’ v sluzhbi krainoî Chekhyzatsiî Rusinov,” Vpered (22 August 1925), 2.

88 “Nový časopis v Podkarpatskej Rusi," Slovenská politika (31 January 1925). ANM Fond Starý, carton 1.
} 
Podkarpatské hlasy began without open affiliation to a political party but within a year of publication it had revealed links with the ruling Czechoslovak Agrarian Party ${ }^{89}$ This encouraged Rusyns to view Podkarpatské hlasy as a tool of the Czech administration, particularly of vicegovernor Rozsypal. ${ }^{90}$ Voloshyn blamed Rozsypal for withdrawing government support for the Ukrainophile newspaper Rusyn, which had been supported by former vice-governor Ehrenfeld, and in place of it "supporting Czech daily 'Podkarpatské hlasy' which promotes a program of Czechization in Ruthenia." ${ }^{91}$ Russophile Russkaia zemlia considered Svojše to be so influential within the government hierarchy that he was above the law, an untouchable force that Rusyn protests could not dislodge. ${ }^{92}$ Czechization policies which Svojše promoted in Podkarpatské hlasy, particularly for the expansion of Czech schools in Rusyn villages, often later became reality, leading Rusyns to label Podkarpatské hlasy a "political meteorologist" which could predict future government trends. ${ }^{93}$ After a slow start, Podkarpatské hlasy sold well among Czech officials because it was the only Czech-language daily newspaper in Ruthenia and because of the notoriety surrounding its confrontational editor. ${ }^{94}$ Svojše dared to say things in print that many Czech officials thought inwardly but had never expressed publically. ${ }^{95}$

Svojše personified the worst fears of Rusyns who felt threatened by the spread of Czechization. Voloshyn's party organ Svoboda referred to Podkarpatské hlasy as "Podkarpatské prase" ["Subcarpathian pig" in Czech], ${ }^{96}$ while Podkarpatská Rus called Podkarpatské hlasy a radical example of "Czech provincial chauvinism." ${ }^{97}$ After just one month of Podkarpatské hlasy's existence the editor of Russophile Russkaia zemlia lamented that "the cultural goals of Podkarpatské hlasy had already been accepted" among many Czech officials and gendarmes. ${ }^{98}$ Svobodnoe slovo declared that due to Svojše's negative influence, “our 'brother Czechs' are now doing the same thing that they did to their German population [...] Czechizing Subcarpathian Ruthenia by force."99 Gagatko's Carpatho-Rusyn Labour Party drafted a "Resolution against

\footnotetext{
${ }^{89}$ Avhustyn Voloshyn, Report for President T. G. Masaryk, 6 April 1928. AÚ TGM Fond TGM-R, carton 403.

${ }^{90}$ Avhustyn Voloshyn, Report for President T. G. Masaryk, 6 April 1928. AÚ TGM Fond TGM-R, carton 403.

${ }^{91}$ Avhustyn Voloshyn, Report for President T. G. Masaryk, 6 April 1928. AÚ TGM Fond TGM-R, carton 403.

92 "Bosniaky y Russkii Ivan,” Russkaia zemlia (17 March 1927), 1.

93 “Sensace Užhorodu a celé Podkarpatské Rusi,” Našinec (17 February 1928), 4.

94 “Sensace Užhorodu a celé Podkarpatské Rusi,” Našinec (17 February 1928), 4.

95 “Sensace Užhorodu a celé Podkarpatské Rusi," Našinec (17 February 1928), 4.

96 “Podkarpatské prase," Svoboda (19 November 1925), 2.

97 “P. Hlasy proti kyrilici a pravoslaví,” Podkarpatské hlasy (30 March 1926), 2.

98 "Kul'tura 'Podkarpatských hlasů' uzhe prynymaetsia," Russkaia zemlia (12 February 1925), 1.

99 "Uchytes po Cheshsky," Svobodnoe slovo (4 July 1925), 1.
} 
Podkarpatské hlasy" in July 1925, saying that they had to "act to defend the Rusyn nation."100 The resolution called on all Rusyns to "protest against the intentional neglect of the Rusyn nation by this group of Czech journalists and the impact they have had among members of Czech society." Podkarpatské hlasy as a means of spreading their message of Czechization.

Svojše could see the firestorm of anger hurled against him in the Russophile and Ukrainophile newspapers, but the anti-Rusyn tone of his editorials continued unabated. He responded directly to the accusations that he promoted Czechization by suggesting Rusyns would willingly assimilate once they realized the benefits it could have for them: "We don't want to Czechize anyone in Ruthenia; the idea has never even occurred to us! [...] For Czech children in Ruthenia there will be Czech schools, and Czech schools can also be for you, if in the interests of a better future for your children you wish to send them to a Czech school!" 102 He wished to modernize Ruthenia as quickly as possible, and the Rusyn intelligentsia's demands for autonomy had to be pushed aside for the greater good. His reaction to the intelligentsia's hatred of him appeared in a cartoon in Podkarpatské hlasy in February 1926 (see Figure 5.2); Svojše stood between menacing Russophiles and Ukrainophiles pleading for them to remember the principles of Slavic brotherhood between Czechs and Rusyns.

Svojše expressed his vision of Ruthenia as a Czech imperial colony in bold and controversial statements. In the editorial of Podkarpatské hlasy's second edition he directly compared Czech officials in Ruthenia to British officials in India, with the only difference between them being that conditions for officials were better in India:

There is no other region in Europe which is as uncultured as Subcarpathian Ruthenia, it can be fully compared with Asia. And here we will dare to make a small comparison: The English government, when they send their officials to India, pay them hundreds of thousands in salary, give them a whole staff of servants, and a luxurious bungalow to live in. Our government sends us there to face conditions which are even worse, but they send us on our way with only a sack, as if we were intended to go begging. ${ }^{103}$

\footnotetext{
100 “'Rezoliutsiia protyv 'Podkarpatských hlasů,", Russkaia zemlia (2 July 1925), 1.

101 “Rezoliutsiia protyv 'Podkarpatských hlasů,", Russkaia zemlia (2 July 1925), 1.

102 “Česká škola na Podkarpatské Rusi,” Podkarpatské hlasy (7 February 1925), 1.

103 “Naši největší nepřátelé,” Podkarpatské hlasy (10 January 1925), 1.
} 
Figure 5.2 - "The Idea of Slavic Reciprocity in Practice in Ruthenia," (1926) ${ }^{104}$

\section{Myšlenka slovanské vzájemnosti jak se na Podk. Rusi praktiku}

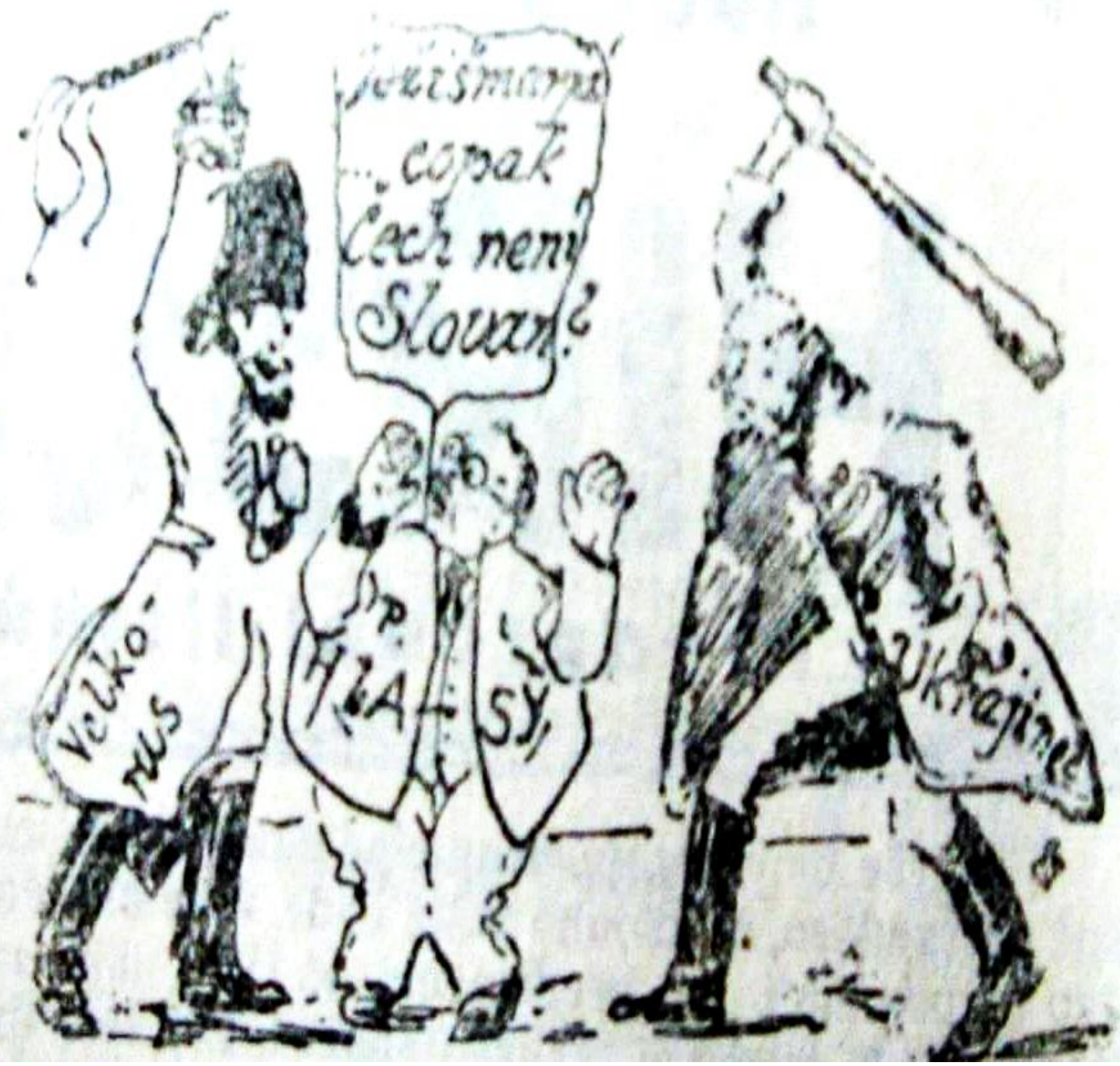

František Svojše stands in the middle, with a Russophile Rusyn on the left and a Ukrainophile Rusyn on the right. Svojše: "Good God, a Czech isn't a Slav?"

\footnotetext{
104 “Myšlenka slovanské vzájemnosti jak se na Podk. Rusi praktiku," Podkarpatské hlasy (23 February 1926), 3.
} Photograph by the author. 
As a former gendarme, Svojše could relate to the day-to-day concerns of the common Czech gendarme, notary or local official, and low wages in relation to the cost of living had been a common complaint. ${ }^{105}$ Although Czech officials were his intended audience, the colonial message in Svojše's "India” comparison did not go unnoticed among Rusyns. Svobodnoe slovo reprinted the offending "India” passage and its editor declared that Svojše "clearly hadn’t learned any geography" and asked "Who is forcing you to stay here in Carpathian Ruthenia? It's not logical to live here if this place is 'Asia' for you, so why don't you stay in your wonderful Europe?",106

Svojše continued to promote his Czechization campaign by referencing European colonial practices in the Orient. He claimed in January 1925 that Czech officials in Ruthenia needed to apply techniques for dealing with the local population "purely according to proven principles of the Orient" and laid out goals for achieving them through education. ${ }^{107}$ Svojše referred to the Orient when describing how teaching Czech in the schools of Ruthenia would build a better future there, just as the teaching of the French language in colonial schools was a benefit to their colonies and to France:

they have French schools for non-French children not only in their colonies, but all across the Orient, where the value of these French schools has been the establishment of the French language as the dominant language not only among the intelligentsia, but also to a large extent in commerce, which is of great benefit to France. [...] Any Frenchman would certainly agree that the same is needed here. ${ }^{108}$

Svojše's repeated use of the Oriental colony metaphor was in keeping with his intention to Czechize Ruthenia for the benefit of the republic and his belief that Rusyns were unfit to govern themselves.

Drawing unflattering parallels with Bosnia and Herzegovina gave Rusyns a means of criticizing Svojše and Czech officials. Among the Rusyn intelligentsia Svojše and the journalists behind Podkarpatské hlasy became known as "The Bosnian Czechs" since many of them had

\footnotetext{
105 Jaromír Nečas, Report for President T.G. Masaryk, 18 August 1921. AÚ TGM Fond TGM-R, carton 401.

106 “Cheshskaia iumorystycheskaia hazeta, 'Podkarpatske hlasŷ'," Svobodnoe slovo (19 February 1925), 2.

107 “Čech na Podkarpatské Rusi - bez práv!” Podkarpatské hlasy (17 January 1925), 2.

108 “Česká škola na Podkarpatské Rusi,” Podkarpatské hlasy (7 February 1925), 1.
} 
come from previous positions in Bosnia during the last years of Austro-Hungary. ${ }^{109}$ The label served as a means of lowering the status of these officials as a show of disrespect for their authority. Svobodnoe slovo mockingly referred to Svojše in many of its articles as "the Bosnian gendarme" rather than using his real name. ${ }^{110}$ Kurtiak's organ Russkii vîstnyk pointed out the dangerous influence of Svojše and the "Bosnian Czechs" on other officials who did not approve of Czechization:

Czechs who were not in Bosnia did not at first understand the methods of Svojše and the 'Bosnians' and many of them protested against the articles he published in Hlasy. However, the ideas of the 'Bosnians' have begun to spread more and more widely among Czech officials. Now we can count on our fingers the number of officials that have yet to be infected with the Bosnian illness. $^{111}$

The "Bosnian illness" referred to the wave of Czechization and corruption which Russkii vîstnyk suggested was sweeping across Ruthenia. Russkaia zemlia vented its anger at the corruption it saw among the officials it labelled "Bosnians" working in Ruthenia: "Freedom has brought Subcarpathian Ruthenia many good things, but also many bad things, a lot of evil to Ruthenia. The greatest evil came from Bosnia, giving us Czechs who stole like crows."

Despite Rusyn concerns about the imminent dangers posed by these "Bosnian Czechs," not all Czech officials in Ruthenia supported Svojše's Czechization plans. Several other Czechlanguage weekly newspapers existed in Ruthenia for an audience of Czech officials and gendarmes, including the Czechoslovak National Democratic Party organ Podkarpatská Rus, and Hlas východu, backed by the Social Democratic party. Both publications favoured a more moderate approach and promoted cooperation with the Rusyn intelligentsia, ${ }^{113}$ and both criticized Svojše for his dangerously polarizing influence on Czech-Rusyn relations, with Podkarpatská Rus referring to Podkarpatské hlasy as "the sadly notorious organ of Svojše.",114 However, Rusyns worried that Svojšs's brash Czechization rhetoric had become a widespread political consensus among the officials, pushing moderate Czech voices into the background.

\footnotetext{
109 "Nashi Bosniaky,” Russkii vîstnyk (7 April 1927), 3-4.

${ }^{110}$ Svobodnoe slovo (6 January 1925), 1.

111 “Nashy Bosniaky,” Russkii vîstnyk (7 April 1927), 3-4.

112 “Bosniaky y Russkii Ivan,” Russkaia zemlia (17 March 1927), 1.

113 “Novoroční úvaha v r. 1928," Podkarpatská Rus (5 January 1928), 1.

${ }^{114}$ Podkarpatská Rus (13 March 1928), 2.
} 
Svojše's notoriety among Rusyns increased as his status as a voice for Czechization in the administration grew, but his influence came to an abrupt halt in February 1928. Gendarmes arrested Svojše after discovering that he was a pedophile involved in regular sexual encounters with children from one of the local public schools in Uzhhorod. ${ }^{115}$ Svojše's crime was considered so unpalatable that many Czech newspapers in Prague referred to the charges against him simply as "crimes against decency." meetings which involved 8 to 14 year old boys and girls," meetings which had taken place for at least two years "in his flat and even supposedly in his office." ${ }^{117}$ Czech daily Našinec alleged that Svojše had tried to bribe some of the parents of the children involved to remain silent after they had learned of his activities. ${ }^{118}$ In addition to charges of public indecency, the subsequent investigation looked into accusations that he had embezzled government funds during his time as a gendarme. ${ }^{119}$ Czech publication Štit claimed that 100,000 Czech crowns had disappeared from a treasury office Svojše had been resposible for as a gendarme, ${ }^{120}$ while Našinec questioned how Svojše could have afforded to buy the large house he owned in the hills outside Uzhhorod. ${ }^{121} \mathrm{He}$ received little sympathy from the Czech media, with Lidové noviny drawing attention to Svojše's $140 \mathrm{~kg}$ weight and former life of excess in Uzhhorod in which " 20 beers and 2 litres of wine were his normal daily intake." 122

The scandal caused a sensation across Ruthenia as the Rusyn intelligentsia watched the very public downfall of their hated enemy. Russkii vistnyk rejoiced that a man who "we [Rusyns] feared" and "symbolized the guiding light of the Czech nation in this eastern part of their empire" would no longer pose a threat. ${ }^{123}$ The criminal charges acted to silence Svojše as a voice for Czech assimilation, since just a few weeks after his arrest pressure from government prosecutors forced him to sell Podkarpatské hlasy. ${ }^{124}$ Although Podkarpatské hlasy continued to act as a voice for Czech officials, without Svojše at the helm it lost much of its confrontational

\footnotetext{
115 “Sensace Užhorodu a celé Podkarpatské Rusí,” Našinec (17 February 1928), 4.

116 "Nemožné poměry na Podkarpat. Rusi," Lidové listy (28 February 1928). ANM Fond Starý, carton 1.

117 “Sensace Užhorodu a celé Podkarpatské Rusí," Našinec (17 February 1928), 4.

118 “Sensace Užhorodu a celé Podkarpatské Rusí,” Našinec (17 February 1928), 4.

119 "Bojovníci proti 'Př́íšerné reakci'," Štit (23 February 1928), 7.

120 "Bojovníci proti 'Př́íšerné reakci'," Štit (23 February 1928), 7.

121 “Sensace Užhorodu a celé Podkarpatské Rusí,” Našinec (17 February 1928), 4.

${ }^{122}$ Lidové noviny (1 March 1928), 1-2.

123 "Frantyshek Svoishe arestovan," Russkii vîstnyk (16 February 1928), 1.

124 "Vydavatelstvo 'Podkarpatských hlasů’ prodáno v kriminále," Moravsko-slezský denník (3 April 1928). ANM Fond Starý, carton 1.
} 
style and stopped openly promoting Czechization. ${ }^{125}$ Despite the loss of his newspaper Svojše did not quietly disappear from the public eye; during his court proceedings he sued the editor of rival Czech-language Uzhhorod newspaper Hlas východu for slandering his reputation. ${ }^{126} \mathrm{He}$ also tried to bring a case of slander against the editor of Četnické listy, a Prague-based magazine for Czechoslovak gendarmes, for claiming that he had a "destabilizing influence" among the gendarmes and legionaries in Ruthenia. ${ }^{127}$ The criminal case against Svojše dragged on through various courts and appeal sessions until finally a guilty verdict and sentence of three years in prison was upheld in the State Supreme Court in Brno in 1932. ${ }^{128}$

Even from prison, Svojše continued to exert considerable influence on Ruthenian politics. A report by presidential advisor Ivan Parkanyi in 1929 claimed that "notorious Svojše's clumsy and abusive writing" had caused a lot of damage in relations with Rusyns, and that his influence and thinking still remained strong among certain groups of officials in Ruthenia. ${ }^{129}$ Parkanyi claimed that Podkarpatské hlasy had "pretended to be 'an independent daily defending the interests of Czech people in Ruthenia and Eastern Slovakia',' but that Svojše's promotion of Czechization for the territory did not reflect the opinion of the majority of Czech officials. ${ }^{130}$ Interior Ministry documents had mentioned the existence of Podkarpatské hlasy prior to Svojše's arrest, but condemnation of his Czechization policies appears to have arisen only after the criminal charges had been laid against him. ${ }^{131}$

In the wake of Svojše's downfall, some Rusyns labelled him an example of all that had gone wrong with the project of Czech administration for Ruthenia. Ukrainophile leader Avhustyn Voloshyn, long a supporter of the Czech administration, wrote to President Masaryk a month after Svojše's arrest to protest against the corruption and low morals he had witnessed among Czech officials. The Svojše scandal appears to have inspired his letter, since he

\footnotetext{
${ }^{125}$ Attacks on Podkarpatské hlasy in Rusyn newspapers went from very frequent from 1925-1927 to almost none after Svojše's departure from the newspaper in 1928.

126 "František Svojše žaluje," Lidové noviny (5 March 1930), 5.

127 "František Svojše žaluje," Lidové noviny (5 March 1930), 5; See also "Případ Svojše a četnictvo," Četnické listy (15 May 1931, no.10), 1.

128 “Konce Františka Svojšeho," Lidové noviny (20 October, 1932), 8.

${ }^{129}$ Ivan Parkanyi, "Poměry na Podkarpatské Rusi," 12 June 1929. Presidential office document no. T 737/29. AÚ TGM Fond TGM-R, carton 403.

${ }^{130}$ Ivan Parkanyi, "Poměry na Podkarpatské Rusi," 12 June 1929. Presidential office document no. T 737/29. AÚ TGM Fond TGM-R, carton 403.

${ }^{131}$ Uzhhorod Administration Report for the Interior Ministry, July 1925. AÚ TGM Fond TGM-R, carton 403.
} 
repeatedly referred to "The affair of the editor of "Podkarpatské hlasy"” arrested for "a scandalous orgy with young girls and boys."132 More broadly however, Voloshyn's letter suggests he considered Svojše merely symptomatic of the general trend towards immorality and disrespect for Rusyns which had developed among Czech officials. He described this gradual transition from humanitarianism to corruption and imperialism:

During the first years the Republic assigned officials to us who learned the Rusyn language and supported our cultural and economic work. Now these Czechs behave differently, they behave contemptuously towards us and they act with the spirit of dictators. This is the result of a decline in morals which is sadly proven by affairs which have been written about extensively by journalists. $^{133}$

To impress on Masaryk the failure of morals among Czech officials serving in Ruthenia he listed "only the most recent scandals which have occurred," including Svojše and three cases of embezzlement and fraud involving the Uzhhorod police captain and financial auditors. ${ }^{134}$ Since the Rusynophile and Russophile leaders Kurtiak, Gagatko and Iosif Kaminskii were already hostile towards the Uzhhorod administration, these accusations from Voloshyn served as a signal to the Prague government that relations with Rusyns had reached a new low.

The Ruthenian Communist Party also used Svojše's scandal to their advantage, calling it a prominent example of the corrupt regime operating in Ruthenia, "a colonial system which is as dark as any in Africa." 135 In March 1928, a month after Svojše’s arrest, Ruthenian Communist MP József Gáti addressed the Czechoslovak national parliament with a speech focused on the many "day to day scandals of the governing colonial regime," highlighting among them "The head of the Czech chauvinist press, Svojše, [...] who has gone to prison because of an orgy with boys and girls who were younger than fourteen."136 Gáti feigned surprise that gendarmes supposedly loyal to such a corrupt and powerful figure as Svojše had willingly arrested him. ${ }^{137}$

\footnotetext{
${ }^{132}$ Avhustyn Voloshyn, Report for President T. G. Masaryk, 6 April 1928. AÚ TGM Fond TGM-R, carton 403.

${ }^{133}$ Avhustyn Voloshyn, Letter to President T. G. Masaryk, 19 March 1928. AÚ TGM Fond TGM-R, carton 403, document no. 2258/28.

${ }^{134}$ Avhustyn Voloshyn, Letter to President T. G. Masaryk, 19 March 1928. AÚ TGM Fond TGM-R, carton 403, document no. 2258/28.

${ }^{135}$ József Gáti, Speech to the Czechoslovak national parliament, 13 September 1928, Session 159.

136 József Gáti, Speech to the Czechoslovak national parliament, 22 March 1928, Session 138.

${ }^{137}$ József Gáti, Speech to the Czechoslovak national parliament, 22 March 1928, Session 138.
} 
Gáti also accused the Prague government of "consolidation of the colonial system" in Ruthenia, through the use of "Asian methods of oppression used against the indigenous population." 138

Responding to such accusations made against them, Czech officials sought to defend their record in Ruthenia. One of the most passionate defences of the work done by Czech officials came from Agrarian Party appointee Jan Brandejs, who by 1928 had become an important figure in the Uzhhorod administration. ${ }^{139}$ Writing in Podkarpatské hlasy in October 1928, Brandejs addressed Gáti and others who had accused Czech officials of imperialism:

The biggest lies told are about a colonial economy, about an administrative dictatorship, about unjust rule. [...] The Czechoslovak state considers Ruthenia to be a colony and arranges the system there like a colonial economy. This was said this year by some in our national parliament. [...] Is the Czechoslovak state regime in Ruthenia of this character?

Brandejs then presented the accomplishments of the administration as evidence that Czech rule should not be considered colonial:

The Czechoslovak state administration has, for ten years, protected the inhabitants from dying of hunger, [...] cared for the health of the people, [...] made great effort to support public education, and so on. Where is the mark of a colonial regime here? Where is the mark of oppression here? [...] It is not a colonial Czechoslovak regime in Subcarpathian Ruthenia, the truth is that a colonial regime ruled here very cruelly before the year 1918 during Hungarian rule. $^{140}$

In support of his claim that Czech officials were not imperialists, Brandejs highlighted the benefits which Czechoslovak rule had brought to Rusyns: "The Czechoslovak state has invested 100 million crowns in Ruthenia, [...] the colonial Hungarian regime invested nothing in Ruthenia and left the land and the people neglected. The Czechoslovak state administration is building a land of civilization, culture, a better life for citizens." ${ }^{\prime 141}$ Brandejs published these comments in Podkarpatské hlasy in the edition celebrating the tenth anniversary of the Czechoslovak Republic, but in Uzhhorod there was little cause to celebrate. Rusyns of most political backgrounds actively opposed the Czech administration and desired autonomy.

\footnotetext{
${ }^{138}$ József Gáti, Speech to the Czechoslovak national parliament, 22 March 1928, Session 138.

139 “Ještě k otázce urbariální úpravy,” Podkarpatské hlasy (25 February 1936), 2.

${ }^{140}$ Jan Brandejs, "Deset let práce republiky na Podkarpatské Rusi," Podkarpatské hlasy (28 October 1928), 3.

${ }^{141}$ Jan Brandejs, "Deset let práce republiky na Podkarpatské Rusi," Podkarpatské hlasy (28 October 1928), 3.
} 
The first ten years of Czech rule in Ruthenia ended in a state of intense distrust between the Rusyn intelligentsia and Czech officials. The union of 1919 had initially offered such wonderful promises of Slavic brotherly love that it came as a shock to Rusyns that Czech officials could take on a similar mantle as their previous Hungarian rulers. Although many Czechs who came to work in Ruthenia did so in the true spirit of Slavic solidarity, a considerable number did so for personal profit. Corruption and abuse of office flourished in the Ruthenian countryside where there was little official oversight of transactions and activities. Disrespectful behaviour towards Rusyns showed them that Czechs did not consider them to be equal citizens in the new Czechoslovak republic.

The appearance of Svojše and his promotion of Czechization in Podkarpatské hlasy became the spur that drove the Rusyn intelligentsia to organize and actively struggle for autonomy. For the autonomists Svojše symbolized what they thought the Czech administration had become, a colonialist system which did not have the best interests of the local inhabitants in mind. Although Rusyns rejoiced at the downfall of Svojše, he had been partly responsible for getting Russophile, Rusynophile and Ukrainophile Rusyns to work together in the fight against a common enemy. As a symbol of Czech imperialism and assimilation policies, the "Bosnian gendarme" had been a catalyst for the growing Rusyn autonomy movement. Czech officials such as Brandejs saw the danger of allowing accusations of imperialism to go unchallenged, but the government would find itself rejecting such accusations repeatedly during the second decade of the First Republic. As we shall see, accusations of imperialism in Ruthenia came from Czechs as well. 


\section{Chapter 6}

\section{Ivan Olbracht and the Czech Anti-Imperialist Movement ${ }^{1}$}

"Uzhhorod is a city of two conquerors: Czechs and Hungarians. The former conquerors and the new conquerors." 2 With this attention-grabbing description of the capital city of Ruthenia, Czech author Ivan Olbracht sought to educate the Czech public about the imperialist character he felt lay at the heart of Czech activities in the most eastern territory of the Czechoslovak Republic. His book Země bez jména [Land without a Name] appeared in 1932, a year after Olbracht had begun to spend significant amounts of time in Kolochava/Koločava, a village in the remote Verkhovyna [Highland] region of Ruthenia. Over the next five years Olbracht would publish several more books and even produce a film about Ruthenia, all of which expressed his doubts that the Czech administration was acting in the best interests of the Rusyn people. Olbracht became the most visible face of a Czech anti-imperialist movement among Communists and the left-wing who attacked the Prague government's policies in Ruthenia on ethical grounds. Although Olbracht's anti-imperialist writings received significant attention from Czech scholars in the Communist period, ${ }^{3}$ non-Communist scholarly studies of Olbracht have largely ignored his anti-imperialist message, focusing on the literary attributes of his work.

The rise of Czech anti-imperialism coincided with anti-colonial and anti-imperialist movements in many European colonial powers in the early twentieth century. British and French socialists and Communists attacked colonial occupation of territories beyond Europe as symbolic of capitalist exploitation of the working classes; ${ }^{4}$ such Marxist intellectuals spoke of the "epoch

\footnotetext{
${ }^{1}$ An earlier version of this chapter has been published by the author as "Blaming the Bourgeoisie: The Czech LeftWing Response to Perceived Czech Imperialism in Subcarpathian Ruthenia, 1931-1935," in New Zealand Slavonic Journal (2012, vol. 46), 71-90. Published while under supervision at Victoria University of Wellington.

${ }^{2}$ Ivan Olbracht, Země bez jména (Prague: Otto Girgal, 1932), 28.

${ }^{3}$ See in particular Ludmila Lantová, Afterword to Hory a staletí by Ivan Olbracht (Prague: Československý spisovatel, 1982), 240-261; other Communist-era works on Olbracht include Lenka Adamová, Ivan Olbracht (Prague: Horizont, 1977); A.M. Píša, Ivan Olbracht: Edice portréty spisovatelů (Prague: Československý Spisovatel, 1982); Vlastislav Hnízdo, Ivan Olbracht (Prague: Melantrich, 1977).

${ }^{4}$ Danièle Joly, The French Communist Party and the Algerian War (New York: St. Martin's Press, 1991), 20-21.
} 
of imperialism" as the "dominant form" of capitalist expansion, ${ }^{5}$ drawing on Lenin's observation of imperialism as "the highest stage of capitalism." In his analysis of interwar anti-colonialism in Britain, historian Stephen Howe concluded that the Communist Party and left-wing factions within the Labour Party opposed British colonial rule in the interests of equal rights for all citizens of the Empire. ${ }^{7}$ Similarly, Czech Communists accused the Prague government of using imperialist practices and neglecting the basic physical needs of Czechoslovak citizens going hungry in the highlands of Ruthenia.

Condemning the Czech administration in Ruthenia as imperialist was common practice for Hungarian revisionists, Rusyn-Americans and pro-autonomist Rusyn intellectuals. ${ }^{8}$ The Rusyn autonomist and left-wing press in Ruthenia, such as Uzhhorod and Mukacheve publications Russkaia zemlia, Russkii vîstnyk, Vpered and Holos zhyttia, reacted with scathing criticism towards the Czech imperialist policies they perceived to be emanating from Prague. Among Czech circles, however, use of imperialist rhetoric to criticize Prague government policies in Ruthenia came predominantly from among Communists and the political left. The Czechoslovak Communist Party attacked the Prague government for its perceived capitalistimperialist practices in Ruthenia, "which correspond to the interests of the Czech bourgeoisie but are completely at odds with the class situation, the psychology and the economic efforts of the Subcarpathian people." 9 Czech authors with Communist political leanings such as Olbracht, Stanislav Kostka Neumann and Vašek Káňa formed another key group of left-wing intellectuals who brought a strong sense of moral authority to bear on Czech policies for Ruthenia.

Olbracht and Neumann's reaction to Czech imperialism had great significance because of the quantity of material they produced and the broad impact it had among the Czech public. Olbracht's work reached a large Czech audience due to his fame as the author of the novel Nikola Šuhaj loupežnik [Nikola Šuhaj the Outlaw]. His self-imposed exile in Ruthenia led him to become a moral conscience of Czech imperialism, opening the eyes of Czech readers by

\footnotetext{
${ }^{5}$ Tom Kemp, "The Marxist Theory of Imperialism," in Studies in the Theory of Imperialism, Roger Owen and Bob Sutcliffe, eds. (London: Longman Group, 1972), 18.

${ }^{6}$ Lenin, Imperialism: The Highest Stage of Capitalism, 91-99.

${ }^{7}$ Stephen Howe, Anticolonialism in British Politics: The Left and the End of Empire, 1918-1964 (Oxford: Oxford University Press, 1993).

${ }^{8}$ Hungarian and Rusyn-American opposition to Czechoslovakia's control of Ruthenia is covered in detail in Chapter 8.

${ }^{9}$ József Gáti, Speech to the Czechoslovak national parliament, 9 April 1924. Czechoslovak Chamber of Deputies Stenographer's Records.
} 
humanizing Rusyns and showing their side of the unequal Czech-Rusyn relationship. Olbracht, Neumann and the Communist Party sought to use the Rusyn autonomy question as a means of attacking the bourgeois capitalist direction of the Prague government, and showing the Czech public that assimilationist policies in Ruthenia risked casting the Czech nation in the same role as their former Austrian rulers.

\section{Czech Use of Colonial Terminology as Political Criticism}

Olbracht and Neumann were not the first left-wing Czechs to raise concerns about colonial and imperial practices in Ruthenia; the Czechoslovak Social Democratic Workers' Party had already referred to Ruthenia as a Czech "colony" to score political points against the Czechoslovak government in the 1920s. The party's organ in Plzeň, Nová doba, criticized the ruling Agrarian party's domineering administration "in a territory which is probably regarded as a colony," claiming that the Agrarians had "almost the entire state apparatus at its disposal in Ruthenia, and it intends to make its control complete." 10 The party's Czech-language organ in Ruthenia, Hlas východu, wrote of "real slavery in India and in Subcarpathian Ruthenia" claiming the activities of Agrarian Party officials were similar to those of English colonists: "Our affairs especially with regard to Subcarpathian Ruthenia - are not so far from affairs in India as it would appear."11 Labelling the ruling party's involvement in Ruthenia as colonial served as an attention-grabbing means of attacking the government in the name of socialism.

By the early 1930s the Czech left wing had additional reasons for criticism of the Prague government's policies with the onset of the worldwide economic depression. The crisis bit deeply in Czechoslovakia and the peasant farmers in the highlands of Ruthenia suffered more than citizens in developed regions of the republic. Starvation stalked the highlands each winter despite ongoing aid work by the Czechoslovak Red Cross to help feed those who were most in need. The plight of the highland Rusyns at first received minimal coverage in the Czech press;

\footnotetext{
10 “Bahno na Podkarpatské Rusi,” Nová doba (11 September 1929), 4.

11 “Skutečné otroctví v Indii a na Podk. Rusi," Hlas východu (16 July 1931), 2.
} 
Lidové noviny commented during the winter of 1932 that the "alarming reports" from the highland region had "finally roused not only the public but also officials."12

Members of parliament for the Czechoslovak Communist Party denounced the lack of concern in Prague for the starving Rusyn peasants in the highland. In January 1932 a delegation of Communist Party MPs travelled to Ruthenia and visited several of the most destitute highland villages to get a first-hand impression of the famine there in mid-winter. Following their return to Prague, the MPs gave speeches in the national parliament and published books and newspaper articles condemning the government's response to the crisis.

One of the most significant parliamentary speeches was given by Josef Štětka, who had spent several years working as an organiser for the Communist Party in Ruthenia and eastern Slovakia. Addressing parliament on 22 January 1932, he compared the famine in Ruthenia to conditions in China, depicting Ruthenia as a neglected colony of the Czech government: "I will speak about the land of hungry mouths which thirteen years ago was supposed to be removed from the Hungarian yoke and yet in Czechoslovakia has become a colony of hunger and a colony of death." Štětka went on to describe the opinions of people he had encountered in Ruthenia: "We met a rather well-dressed young man, a local blacksmith, who told us: 'I have been through many parts of the world, I have seen a lot of poverty, but what is happening here is not happening in South Africa with the slaves'." Štětka also evoked the image of Ruthenia as a land of colonial slavery when he asked a Czech engineer what the conditions were like in the territory: "He literally told us: 'In Ruthenia? You still need to ask? After several years here organized banditry rages! There are conditions here which surpass the situation in the colony of Indo-China. There at least the slaves are fed, but in this place the Carpathian people still go without."13 Štětka blamed these conditions of terrible poverty in Ruthenia on the Czech administrators for the region: "notaries, financial officers, even judges, they are all corrupt and they all belong in jail. They serve the interests of the Hungarian-Jewish and Czech financial bourgeoisie." 14 His words acted both to chastise the Prague government for its inaction and to galvanize further support for the Communist Party in Ruthenia.

\footnotetext{
12 "Bida na vrchovině," Lidové noviny (15 January 1932), 5.

13 Josef Štětka, Speech to the Czechoslovak national parliament, 22 January 1932, Session 165.

${ }^{14}$ Josef Štětka, Speech to the Czechoslovak national parliament, 22 January 1932, Session 165.
} 
Figure 6.1 - Cover of Vašek Káňa's Book Transcarpathia (1932) ${ }^{15}$

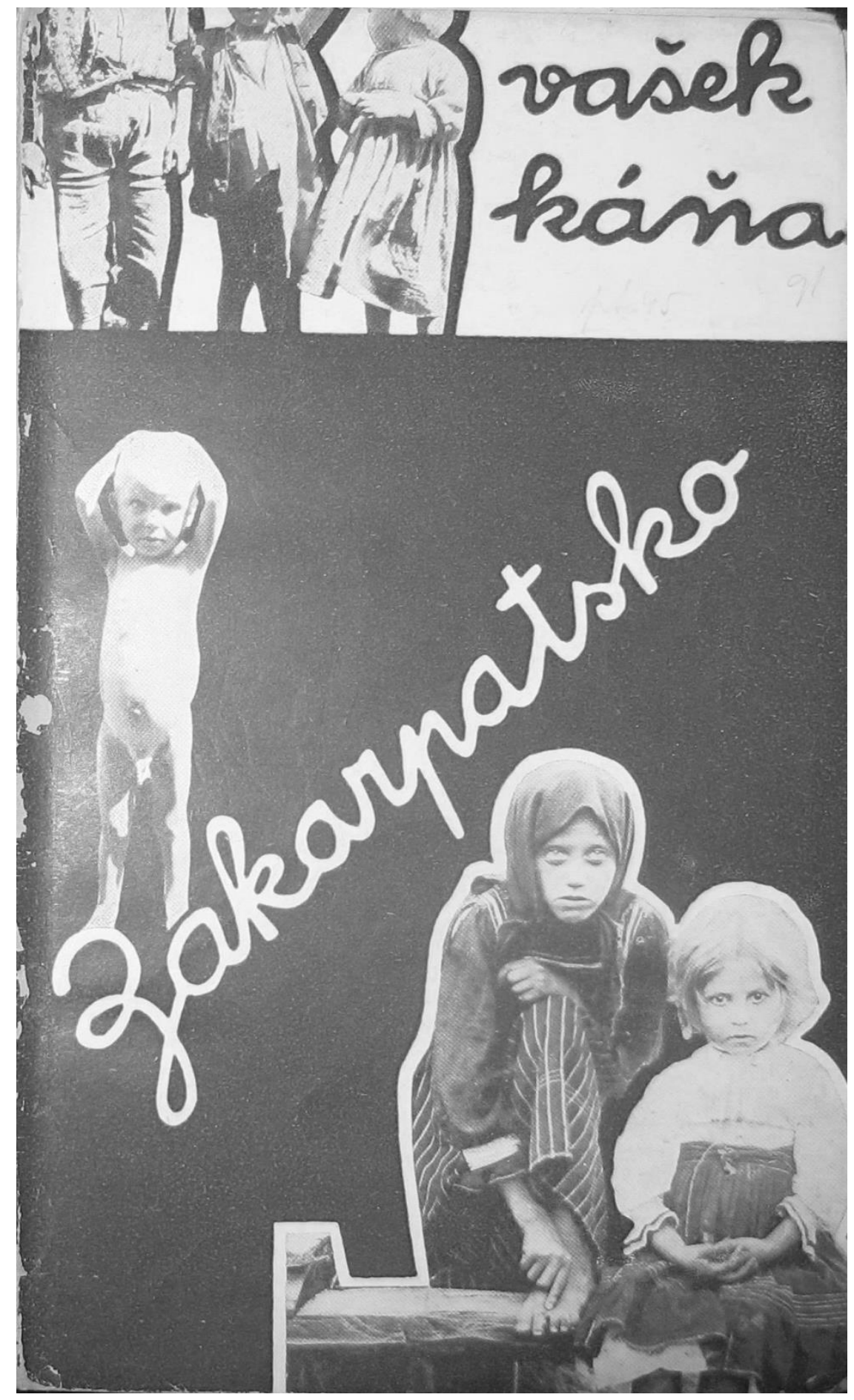

\footnotetext{
${ }^{15}$ Vašek Káňa, Zakarpatsko: Reportáǎ ze života ukrajinského proletariátu v Československu (Prague: Jaroslav Hoffmann, 1932). Photograph by the author.
} 
Following Štětka's speech in parliament, a committee organized by the Czechoslovak Communist Party, Komitét dělnické pomoci pro zachránu hladovějicich v Podkarpatské Rusi [Workers Aid Committee for Rescuing the Starving People in Subcarpathian Ruthenia], published Hlad v Podkarpatsku [Hunger in Subcarpathia], a book to inform the public about the crisis in the Rusyn highlands and the lack of government response. The book included the full text of Štětka's speech to parliament, essays by other Communist Party members, and reports by medical doctors who had worked in the Rusyn highlands. In addition to calling on the government to do more to help the hungry, the book condemned the practice of establishing Czech schools in Rusyn villages as an act of Czechization. The text described the lack of educational equality in the school facilities provided in a typical highland village:

There is a Czech school, which the children of gendarmes and Jewish merchants attend. However, there are no Rusyn schools in the village, there are only rented rooms. One of these schools is in a room which is 5 metres by 8 metres and 2.5 metres high, where 38 children study. According to reports these children only learn to sing and write their names there. ${ }^{16}$

Such complaints about creeping Czechization in the school system filled the pages of the local Rusyn pro-autonomy newspapers, but accusations from Czech sources appeared almost exclusively among the Communists. Motivation for the Communist Party's condemnation of Czechization lay in exposing how the capitalist Prague government had failed to provide for its poorest and most vulnerable citizens by showing preference towards Czechs.

A further significant Communist publication resulted from the expedition to Ruthenia, a book by Vašek Káňa which criticized the Prague government for neglecting starving Rusyn villagers. The book's cover depicted a child with a belly distended by malnutrition (see Figure 6.1), while the opening pages contrasted photographs of a Czech industrialist's mansion in Uzhhorod with the humble thatched-roof "villa" of a large Rusyn family. ${ }^{17}$ After recounting the absolute poverty he had seen in Rusyn highland villages Káňa asked "Are we in some central African colony?"18 He also condemned Czech officials for pursuing policies of Czechization, claiming a local Rusyn had told him, "For one Czech child there is a school - for 100 of ours

\footnotetext{
${ }^{16}$ Hlad v Podkarpatsku (Prague: Komitét dělnické pomoci pro zachránu hladovějícich v Podkarpatské Rusi, 1932), 23.

${ }^{17}$ Kán̆a, Zakarpatsko: Reportáž ze života ukrajinského proletariátu v Československu, book cover and opening photo pages.

${ }^{18}$ Káňa, Zakarpatsko: Reportáž ze života ukrajinského proletariátu v Československu, 84.
} 
there isn't any."19 Káňa blamed the Prague government for denying it had such assimilation plans: "The Czech government is very happy to spread the word in Europe that it is bringing culture to the backwards Subcarpathian people; [...] The Czech government says Czechization isn't happening, it promotes its support of Rusyn culture as evidence of its good work."20

The crisis in Ruthenia in the early 1930s also attracted the attention of Olbracht and Neumann, whose motives for attacking Czech imperialism developed from their political backgrounds in the Communist Party. However, turbulent events in the Party eventually helped steer them towards the opportunity to write about Ruthenia. Both authors were part of a group of Communist writers who opposed the transformation of the Czechoslovak Communist Party following the Fifth Party Congress in 1929. The changes cemented a Bolshevik direction for the Party under Klement Gottwald's leadership and purges following the Stalinist model occurred among the party membership. ${ }^{21}$ Olbracht and Neumann signed the "Manifesto of Seven" condemning the party's change of direction, as did Olbracht's wife Helena Malírová, Vladislav Vančura, Marie Majerová, Josef Hora and Josef Seifert; ${ }^{22}$ the authors formed a closely-knit group who had all worked together on left-wing journals. ${ }^{23}$ The text of their Manifesto appeared on the front page of Lidové noviny on 25 March 1929 under the headline "Communist Authors against the Politburo and the Extraordinary Congress." ${ }^{24}$ All the signees were expelled from the party shortly afterwards.

Following his ejection from the Communist Party, Olbracht searched for a new source of inspiration to guide his literary interests, and he found it by looking to the far east of the Czechoslovak state. A Czech colleague he had worked with in Vienna told him about Ruthenia and encouraged him to visit. ${ }^{25}$ Withdrawing from daily political life in the Bohemian lands offered him new opportunities to dedicate himself to literature, and in 1931 he ventured to the far east of the republic in search of new experiences, first staying in eastern Slovakia for several months, then venturing into Ruthenia and eventually to the highland village of Kolochava, where

\footnotetext{
${ }^{19}$ Káňa, Zakarpatsko: Reportáž ze života ukrajinského proletariátu v Československu, 75.

${ }^{20}$ Káňa, Zakarpatsko: Reportáž ze života ukrajinského proletariátu v Československu, 73.

${ }^{21}$ Zdenek L. Suda, Zealots and Rebels: A History of the Communist Party of Czechoslovakia (Stanford: Stanford University, 1980), 119.

22 Jacques Rupnik, Dějiny komunistické strany Československa (Prague: Acedemia, 2002), 80.

${ }^{23}$ Most of them had written for the Communist Party organ Rudé právo, along with other left-wing publications.

24 "Komunističti spisovatelé proti polbyru a pro mimořádný sjezd," Lidové noviny (25 March 1929, morning edition), 1.

${ }^{25}$ Píša, Ivan Olbracht: Edice portréty spisovatelů, 67.
} 
he would become a regular resident during the next five years. ${ }^{26}$ His great enthusiasm for Ruthenia would inspire Neumann and others from his left-wing literary circle to develop a similar interest in writing about the region's culture, nature and politics.

\section{Ruthenia in Ivan Olbracht's Literary Works}

Olbracht, born Kamil Zeman to a Czech father and a Jewish-Czech mother, took an interest in writing and politics from an early age. He studied law, but left university before completing a degree in order to work as a journalist. ${ }^{27} \mathrm{He}$ worked in Vienna for the Czech Social Democratic newspaper Délnické listy until the end of World War One, when he decided to travel to Russia to see the Bolshevik revolution in action. The six months he spent there made him a firm Communist, and following his return to Prague in 1920 he published a book expressing admiration for the revolution, Obrazy ze soudobého Ruska [Images from Contemporary Russia]. He joined the Czechoslovak Communist party upon its founding in May 1921, and developed links with other left-leaning Czech authors. He was twice imprisoned for his political activism, first in 1926 in Ostrava and then in 1928 in Prague's Pankrác prison. ${ }^{28}$ A book about his time in prison titled Zamrížované zrcadlo [Mirror with Bars], appeared in 1930. Olbracht had also written a short story about a Rusyn soldier named Chomjak in the Austro-Hungarian army, $O$ lásce $k$ monarchii [About Love for the Monarchy] in 1910. The story somewhat resembles Jaroslav Hašek's Good Soldier Švejk, with the character of Chomjak cast as a stereotypical fool in a military regiment. ${ }^{29}$ The story has little connection to Olbracht's later political works about Ruthenia, but confirms that he had taken an interest in the Rusyn nation before the formation of Czechoslovakia.

Olbracht's earliest impressions of the political conditions in Ruthenia appeared in the essay Boj o kulturu na Podkarpatské Rusi [The Struggle over Culture in Subcarpathian Ruthenia]. Spread over four issues of the publication Literární noviny from September to November 1931, the essay was a culmination of the experiences and impressions which Olbracht

\footnotetext{
${ }^{26}$ Olbracht's personal letters from the years spent in Kolochava have been collected and published as Korespondence s rodinou: Koločava 1931-1936 in the 1966 publication Z rodinné korespondence Ivana Olbrachta.

${ }^{27}$ Adamová, Ivan Olbracht, 17-18.

${ }^{28}$ Adamová, Ivan Olbracht, 122.

${ }^{29}$ Ivan Olbracht, "O lásce k monarchii," in Bejvávalo (Prague: Československý spisovatel, 1954): 47-71.
} 
had gathered while based in the town of Mizhhiria in the Rusyn highlands. It began with an urgent question for the Czech reading audience to consider: "Do the people of Subcarpathian Ruthenia hate the Czechs?" 30 He proceeded to answer that question by describing the reasons why Rusyns had a right to feel disgruntled about their status in Czechoslovakia. The first of these reasons was the domination of the Rusyn capital Uzhhorod by Czechs and Hungarians, and Olbracht used this point to evoke memories of Austrian rule for his Czech readers:

Uzhhorod is the capital city of the Rusyns? But where are the Rusyn people? [...] In Uzhhorod you don't see any Rusyns at all. In the capital city they are only an afterthought. Their language is there along with Czech and Hungarian on the street signs and also under the two lions on the state administrative office, but this is just diplomatic window dressing. [...] On bookshop shelves there are Czech school textbooks; [...] you can't find Ukrainian books, or Russian books, or books in the Rusyn dialect here. [...] The bookshop staff member offered me a Czech-Ukrainian dictionary, but a Ukrainian-Czech dictionary wasn't available. [...] Signs on the big shops are in Czech/Hungarian or only Czech [...] Why don't they have Ukrainian signs? Don't they want Ukrainian customers?

Such questions about language politics would likely have been an uncomfortable reminder for Czech readers that it had been not so long ago that official signs in the Bohemian lands and in their own capital Prague had been written in German.

Olbracht also suggested that Czech officials in Ruthenia had begun to adopt the same imperialist habits as the former Hungarian rulers. He noted that Rusyns referred to Czechs using the same term they had used for the Hungarians, "master" [pán]: "Everyone here who is a 'master', or looks like a master, speaks Czech." He considered this a natural reaction to the Czech domination of Ruthenian society under a form of imperial rule:

If we see Czech schools in Ruthenia without Czech students, the large Czech administrative apparatus, the agricultural colonies of the Czech legionaries, the setting up of so many Czech shops and businesses, we can't avoid seeing the pattern. In doing so, we cannot forget the Hungarian past in this land. [...] Now the Czechs are starting the old game all over again. ${ }^{31}$

Czech media coverage of Ruthenia in the early years of the republic had criticized the previous Hungarian administration for its uncaring attitude towards the Rusyn population and the bright future which awaited these Slavic brothers in Czechoslovakia. As a result, Olbracht's claim that

\footnotetext{
${ }^{30}$ Ivan Olbracht, "Boj o kulturu na Podkarpatské Rusi," Literární noviny, issue 16 (September 1931), 5.

${ }^{31}$ Ivan Olbracht, "Boj o kulturu na Podkarpatské Rusi," Literární noviny, issue 20 (November 1931), 3.
} 
Czech officials had replaced Hungarians as the new "masters" in Ruthenia would likely have been unsettling for his Czech readers, as it contradicted the image of a caring Czech nation helping fellow Slavs which the Czech press had established.

Olbracht agreed with Štětka and Káňa that Czechization in the Rusyn school system would lead to increased friction with the Rusyn population. Czech schools opened in settlements with just a few Czech children, usually the children of Czech gendarmes, and some Jewish parents encouraged their children to learn the main language of the republic, sending them to these Czech schools as well. ${ }^{32}$ As a result many villages with few or no Czech children received new Czech schools, while the local Rusyn children faced the option of continuing to attend lowquality Rusyn schools in old, overcrowded buildings or attending Czech schools. Olbracht stressed that aggressively expanding the number of Czech-language schools contributed to antiCzech sentiment among Rusyns, observing that "there is only one thing the Czech schools don't have: Czech students." 33

The final sentence of Boj o kulturu na Podkarpatské Rusi expressed Olbracht's hope that the Rusyn people could resist Czechization by adopting a unified direction for their national loyalty: "Subcarpathian Ruthenia will be Ukrainian." ${ }^{34}$ He believed that finding a single national direction would enable the Rusyn people to work together more effectively to resist assimilation, and that Ukrainian had the upper hand in the cultural struggle. He also quoted the words of a Rusyn intellectual who declared they would never allow themselves to become Carpathian Czechs: "like we resisted becoming Hungarian, we don't want to be Czech either. We are Rusyns and we want to speak and write the language which God gave us. Rusyn." 35

Olbracht's essays in Literární noviny would eventually be included in his book about the political situation in Ruthenia titled Země bez jména [Land without a Name] published in 1932. The book, subtitled "Reportage from Subcarpathia," expressed Olbracht's concern that "Czech 'masters' are colonizing Subcarpathian Ruthenia,"

\footnotetext{
32 Jelinek, The Carpathian Diaspora: The Jews of Subcarpathian Rus 'and Mukachevo, 217.

${ }^{33}$ Ivan Olbracht, "Boj o kulturu na Podkarpatské Rusi," Literární noviny, issue 19 (November 1931), 4.

${ }^{34}$ Ivan Olbracht, "Boj o kulturu na Podkarpatské Rusi," Literární noviny, issue 20 (November 1931), 3.

${ }^{35}$ Ivan Olbracht, "Boj o kulturu na Podkarpatské Rusi," Literární noviny, issue 19 (November 1931), 4.

${ }^{36}$ Olbracht, Země bez jména, 41.
} 
Czechs direct the economy, politics and language of a region with 709,000 citizens."37 Expanding on the argument he had made in Boj o kulturu na Podkarpatské Rusi, Olbracht stated that the Rusyn habit of referring to Czech officials with the title "master" [pán] symbolized the new imperial relationship: "The Rusyns refer to their rulers as 'masters' when greeting them, and here the Czechs are the "masters'."38 He claimed that the shift from Hungarian to Czech "masters" had at first been welcomed by the Rusyns, but was now resented: "The Czech 'masters' came in the 1920 s bringing freedom. 'In the beginning all Czechs were dear to us' a Rusyn told me. [...] Now the people hate them. Not the Czech nation, [...] but the 'masters' [pány].”

Olbracht also raised questions about the hiring practices for the regional administration, which he claimed made it almost impossible for qualified members of the Rusyn intelligentsia to find employment as officials. He described the concerns of a Rusyn father who had worked hard to get his son a good education, yet there were no available jobs for him in the administration:

What can I do for my son? I sent him to study at the educational institute, I thought that he could show the way for his younger brothers, but after one and a half years he still doesn't have a place? Why? [...] They employ only 5\% Rusyns, the rest are Czech. ${ }^{39}$

The Czechoslovak constitution may have guaranteed that officials would be chosen wherever possible from among the local population in Ruthenia, ${ }^{40}$ but in practice few Rusyns achieved positions in the regional administration. ${ }^{41}$

Olbracht suggested that Rusyn resistance to Czechization compared closely to Czech resistance to Germanization in Austro-Hungary: "so much of the public life of this region is oriented towards assimilation by the Czechs. During the fight for national sovereignty in the Bohemian lands our relations with the Germans were the same."42 Olbracht also compared Czech policies for a Russian or Ukrainian orientation to the Rusyn identity to the minority language policies used by the former government of Austro-Hungary:

\footnotetext{
${ }^{37}$ Olbracht, Země bez jména, 37.

${ }^{38}$ Olbracht, Země bez jména, 38.

${ }^{39}$ Olbracht, Země bez jména, 40-41.

${ }^{40}$ Ústavní listina Československé Republiky, 121/1920, 29 February 1920.

${ }^{41}$ Statistics from the Zemski Urad in Uzhhorod suggest the number of Rusyns employed in the administration actually decreased between 1921 and 1935. Cited in: Macartney, Hungary and Her Successors, 225.

${ }^{42}$ Olbracht, Země bez jména, 38.
} 
The government wants Czechization. It wants to make the region into a permanent protectorate. If only one possible direction for the Rusyn identity was to win, if at least the language question for schools could be resolved, Czechization would end, and soon after so would the protectorate. But during the current linguistic, educational and political crisis, the Czechs can do whatever they want.

He concluded by comparing Czechoslovakia to the Habsburg monarchy: "Therefore, 'Divide et impera!? Doesn't it make you think of the old Austrian school of thought?"43

Most Czech reviewers of Zemé bez jména glossed over the anti-imperialist and antiCzech content of the book, but a review in the Olomouc newspaper Našinec praised Olbracht for bringing the issue to public attention: "Here is a book which acts as a personal conscience, and it can only be hoped that this voice will be heard in the appropriate places." However, the reviewer also saw the book as a reflection of Olbracht's left-wing political past, and questioned his argument: "Olbracht was once a communist, and therefore credibility is immediately lost for this cry for justice, freedom and reason, while followers of Rudé právo also reject this work of art."44 The Czechoslovak Communist Party's refusal to approve the book stemmed from Olbracht's expulsion from the party ranks, though the book's anti-imperialist message closely resembled that of Štětka and Káňa.

Olbracht continued to spend more and more time in the Ruthenian highland village of Kolochava after 1931, and while living there he heard tales from the local villagers about a reallife Robin Hood of the Carpathians who had fought against the Hungarians, then Romanians, and finally Czechs, making him a hero of the Rusyn people. Olbracht took these tales about the outlaw character and turned them into a 1933 novel called Nikola Šuhaj loupežník [Nikola Šuhaj the Outlaw]. The fiercely independent spirit of the Rusyn outlaw Šuhaj carries Olbracht's message about the human dignity of the Rusyn people of the highland and their desire to resist foreign occupiers. The novel's Czech gendarmes constantly pursue Šuhaj but he always finds a way to escape into the forests.

Olbracht's novel also depicts the often strained relationship between Czech gendarmes and the local Rusyns in the highland villages. The gendarme Vlásek who guards Nikola Šuhaj

\footnotetext{
${ }^{43}$ Olbracht, Země bez jména, 78.

44 "Ivan Olbracht: Země bez jména," Našinec (1 June 1932), 4.
} 
after his capture had been part of the Czechoslovak Legion in Siberia, and he considers Ruthenia just as foreign as the Siberian plains. Vlásek dislikes being stationed in the village, and Šuhaj convinces him that taking a bribe to help him escape would go unnoticed by his superiors:

'The Czechs won't be here for long' says Šuhaj in a little while. [...] The Germans were here and the Russians, and they have left. The Romanians have disappeared. The Hungarians, too. [...] In a few weeks you'll go away and no one will ask you what happened to Nikola Šuhaj'. [...] How much is it? Vlásek wondered as he looked at the packet out of the corner of his eyes. [...] Who will be able to prove anything? And besides, gendarme duty in this Siberia of a place can go to hell. ${ }^{45}$

Vlásek's comparison of Kolochava village to Siberia suggests that he considered his posting in Ruthenia to be one of equal hardship in a foreign territory, a sentiment which contains Olbracht's argument that Czech officials thought of Ruthenia as a land to be conquered.

Olbracht also uses comparisons to Siberia after Nikola Šuhaj has killed one of the Czech gendarmes, and the group of gendarmes discuss how to respond:

On the evening of that day Šuhaj's family cottage was burnt down. [...] That's what they used to do in Siberia with villages where one of their comrades had been murdered in cold blood. Terror! And more terror! [...] Had they fought in the Siberian steppes and in the rocky Dolomites to perish in this robber's nest of a village? Two days later the funeral of the gendarme who had been shot took place. But no, it was not a funeral, it was a display of armed might before the enemy, a military demonstration in a Siberian village where they found themselves surrounded by a silent sea of hatred. ${ }^{46}$

Olbracht's repeated use of the Siberia comparison highlights his political message that Czech officials in Ruthenia considered the region to be a backwards colony and not an equal part of the Czechoslovak state. Additionally, by crafting Šuhaj as a likeable protagonist, Olbracht encouraged his Czech reading audience to take the side of Šuhaj and the Rusyn peasants against the Czech gendarmes and officials, who he cast as antagonists and outsiders.

Following the publication of Nikola Šuhaj loupežník, Olbracht became interested in making a motion picture about Ruthenia, and discussed the idea with his author friends Vladislav Vančura and Karel Nový. They agreed that the film should be shot on location in Ruthenia, and

\footnotetext{
${ }^{45}$ Ivan Olbracht, Nikola Šuhaj loupežník (Prague: Artia, 1954), 70-72.

${ }^{46}$ Olbracht, Nikola Šuhaj loupežnik, 86.
} 
should use Rusyn peasants to play each of the roles rather than professional actors. Olbracht wrote the story for the 1934 film, which would eventually be called Marijka neverrnice [Marijka the Unfaithful], and based it on a traditional story of infidelity and revenge. ${ }^{47}$ The film invited the Czechoslovak audience to step into the world of the Rusyns and see Ruthenia through Rusyn eyes. The Rusyn actors spoke in their own local dialect and revealed parts of the story and their personal feelings to the audience which were unknown or misunderstood by the Czech gendarmes and officials depicted in the film. Where other Czech film makers might have chosen to cast a Czech protagonist, Olbracht wanted all the main characters to be Rusyns in order to humanize the Rusyn people for the Czech viewing audience. Having all the actors speak in Rusyn, without subtitling, also showed Czech audiences that with minimal effort they could understand Rusyn speech.

Olbracht included several details in Marijka nevérnice which could show his Czechoslovak audience the negative influence which the Czech-dominated administration had caused in Ruthenia. When the Rusyn protagonist's mother wishes to send a letter to him to warn that his young wife is being unfaithful to him, she goes to the elementary school in the village where the Rusyn students are taught in the Czech language. A close-up view of an official sign on the wall of the school is included which declares, in Czech, that it is a state school with Czechoslovak language instruction. The old woman finds a young boy as he leaves the school and asks him to write a letter for her, which he carefully does in the Czech language. It was of course easier for the intended Czech audience of the film to read the letter if it was in Czech rather than the Rusyn Cyrillic script, but Olbracht also likely intended to show his audience that Czech schools were bringing creeping Czechization to even the most remote villages of the Carpathian highlands. Not all Czech viewers would have known that the Treaty of St. Germain and the Czechoslovak constitution promised Rusyns linguistic and cultural autonomy, but the suggestion that fellow Slavs were not able to study in their own language may have acted as a subtle reminder of schools in the Bohemian lands under Austrian rule.

Towards the end of the film a group of Czech gendarmes discuss the revenge murder of a rival Rusyn man by the Rusyn protagonist, and one of them declares that it is impossible to find out the truth from the Rusyns themselves: "You'll never get anything out of them, one's like a

\footnotetext{
${ }^{47}$ Ivan Olbracht, Vladislav Vančura and Karel Nový, Marijka nevěrnice, Czech National Film Archive, 1934.
} 
stranger here." In the following scene, a local Czech official tells his wife the news about the murder, and proclaims that he "can't stand this terrible country anymore" and that the Rusyn protagonist committed the murder because he is "an animal, because of this wolf country, because this country is still in the middle ages." 48 The opinions of the Czech characters would have been familiar to the Czech audience, since they corresponded to the opinions then commonly expressed in the media. However, the audience would have been able to understand the motives for the murder and commiserate with the Rusyn protagonist in a way which the Czech on-screen characters could not because the story had followed all the actions of the protagonist. Thus Olbracht encouraged the film's viewers to look beyond the images of "primitive" Ruthenia which the Czech media had given them and challenge their own preconceptions.

Olbracht himself appears as an actor at the beginning of the film playing the role of a Czech tourist who cares little for the local people he meets and is simply there to enjoy himself, repeatedly asking where he can buy alcohol and cigarettes. The actions of Olbracht's tourist character are indirectly harmful to the Rusyn protagonist, for his suggestion to a young Jewish couple that they should open a "Tourist House" sets in motion the series of events which eventually leads to the Rusyn protagonist losing his home. Oblivious to the harm that his actions have caused, the tourist character returns again at the end of the film, still asking to buy beer and cigarettes. Olbracht likely intended to make his Czech tourist character a clown in the eyes of his Czech audience, in sharp contrast to the proud and honest nature of his Rusyn protagonist.

Following the immense critical and commercial success of Nikola Šuhaj loupežník and the positive reception of Marijka nevěrnice, Olbracht decided to republish Země bez jména together with his essay Boj o kulturu na Podkarpatské Rusi in order to bring his anti-imperialist message to a much larger Czech reading audience. Published in 1935 with a new title, Hory $a$ staletí [Mountains and Centuries], the book also included a new essay which Olbracht had recently written and published in the Prague newspaper České slovo to promote broader public awareness of the Rusyn point of view in the Czech-Rusyn relationship. The article described the

\footnotetext{
${ }^{48}$ Ivan Olbracht, Vladislav Vančura and Karel Nový, Marijka nevěrnice, Czech National Film Archive, 1934.
} 
increasing economic hardships and hunger which the local Rusyns faced, asking "Who is responsible for the events in the east of our republic?"49

When the book Hory a staletí appeared, Olbracht's growing fame ensured that reviewers gave it more attention than Země bez jména had received, with several reviewers, including Lidové noviny, introducing him as "the author of the novel about Nikola Šuhaj, Ivan Olbracht."50 Many Czech reviewers still downplayed the book's anti-imperialist message, though Sokol commented that the author was "full of compassion for the indigenous inhabitants,"51 and Lidové noviny conceded that Olbracht "never withholds his judgement, but his verdict always results from broad wisdom and the gravity of an expert." ${ }^{, 52}$ In his 1938 book Les villes de la Russie Subcarpatique French author Jean Mousset praised Hory a staletí for Olbracht's impartial views on Rusyns and Jews and his willingness to criticize the Czech administration in Ruthenia. ${ }^{53}$ The book was also well received by some Rusyn intellectuals; Iosyf Dudykevych quoted from Hory $a$ staletí in his 1937 book Na marhinesi bidy Pidkarp. Rusy when describing the plight of the Rusyn peasants in the highland. ${ }^{54}$

The popularity of Olbracht's books, particularly Nikola Šuhaj loupežník, endured far beyond the 1930s. Olbracht rejoined the Communist Party in 1945, and following the Communist takeover of Czechoslovakia in 1948, his past as a loyal party member made him a popular author with the new regime. His depictions of an imperialist Czech administration in capitalist interwar Ruthenia found a receptive and welcoming audience, with scholarly literature devoted to trumpeting his Communist past. ${ }^{55}$ Nikola Šuhaj loupežník became standard reading for Czechoslovak school children, and films and theatre plays based on the character of Nikola Šuhaj soon followed. As a result, Šuhaj remains a familiar literary character in the Czech Republic today. The most important achievement of Nikola Šuhaj loupežník in interwar Czechoslovakia was to introduce Ruthenia to a broad audience in the Bohemian lands, giving

\footnotetext{
${ }^{49}$ Ivan Olbracht, "Země starosti," České slovo (17 March 1935).

50 “Kniha moudrosti i lásky," Lidové noviny (27 May 1935), 5.

51 "Reportáže Ivana Olbrachta: Hory a staletí," Sokol (August-September 1936), 212.

52 "Kniha moudrosti i lásky," Lidové noviny (27 May 1935), 5.

53 Jean Mousset, Les villes de la Russie Subcarpatique (Paris: Librairie Droz, 1938), 115-116.

${ }^{54}$ Iosyf Dudykevych, Na marhinesi bidy Pidkarp. Rusy (Uzhhorod: Viktoriia, 1937), 3-4.

${ }^{55}$ See Adamová, Ivan Olbracht; Píša, Ivan Olbracht: Edice portréty spisovateli̊; Hnízdo, Ivan Olbracht; Lantová, Afterword to Hory a staletí by Ivan Olbracht, 240-261.
} 
them a romantic image of the region which was at odds with the pessimistic reports which frequently appeared in the main Czech daily newspapers.

\section{S.K. Neumann's Ruthenia Travel Books}

Olbracht's interest in Ruthenia attracted the attention of his friend Stanislav Kostka Neumann, another Communist writer who had found success as a poet and journalist. In his early years Neumann played a role in the Czech anarchist movement, but after reading the works of Lenin he became one of the founding members of the Communist Party of Czechoslovakia in 1921. During the 1920s Neumann ran his own left-wing journal called Červen, wrote for the Communist Party organ Rudé právo and would later become the editor of the socialist publication Levá fronta. ${ }^{56}$ In 1929 he signed the Manifesto of Seven against Gottwald and the Politburo and faced expulsion from the Communist Party together with Olbracht for rejecting Bolshevization.

In the early 1930s Neumann made numerous trips throughout Czechoslovakia including visits to Ruthenia, and published two travel books about his experiences there. The first to appear was Enciány s Popa Ivana [Flowers from Pop Ivan] in $1933,{ }^{57}$ which described a summer he spent in Rakhiv/Rachov region in the mountainous far eastern corner of Ruthenia. The second, Československá cesta [Czechoslovak Journey] in 1935, included a chapter on his experiences while exploring the Ruthenian countryside called Karpatské léto [Carpathian Summer].

The cover of Československá cesta offers a clue as to the mood Neumann intended to create for his Czech readers; it featured two photographs, one for each section of the book, the first about travels in Ruthenia and the second about travels in Bohemia. The photo for the section Karpatské léto [Carpathian Summer] showed a Rusyn farmer and his sheep in a humble pastoral scene, while the photo for the section Český podzim [Bohemian Autumn] depicted piles of oil barrels in a field surrounded by a tall barbed wire fence which the camera peered through. ${ }^{58}$ The

\footnotetext{
${ }^{56}$ Jiří Taufer, Stanislav Kostka Neumann: Básník, jeho doba a odkaz (Prague: Československý spisovatel, 1975), 143.

${ }^{57}$ Stanislav Kostka Neumann, Enciány s Popa Ivana (Prague: Fr. Borový, 1933). The "Pop Ivan" in the title refers to a mountain in the eastern corner of Ruthenia, today called Pip Ivan.

${ }^{58}$ Stanislav K. Neumann, Československá cesta: část druhá a třetí (Prague: František Borový, 1935).
} 
photo chosen to represent Bohemia was unusual for a travel book and perhaps suggests Neumann wished to encourage his Czech readers to view capitalist Bohemia as unwelcoming and sterile in comparison to the naïve simplicity of life in Ruthenia.

In Československá cesta, Neumann also spoke out against the pressure of Czechization he had witnessed in Ruthenia. He considered it a "terrible mistake" that some Czechs working in the region saw Czechization as the best method for improving conditions in the region: "A Czech teacher here exclaimed: 'Czechize everything, it's the only way to help!' Many other Czechs here, alas, have the same opinion." 59 Neumann also mirrored comments by Olbracht, Štětka and Kaňa in pointing to grave inequalities between the Czech and Rusyn schools in the region:

last year in Volovec a three-room Czech school was built for a million crowns, we didn't see another school that was as nice anywhere in the Carpathian highlands. Last year 96 students attended the school, 14 were Czechs and the rest Jewish. In the Rusyn three-room school 350 students are crammed into two old huts. Would you be surprised to hear that the construction of such a Czech school was considered to be a provocation $?^{60}$

His words likely held an unpleasant echo of Habsburg-era language policies for his Czech reading audience.

Neumann also criticized some Czech tourist visitors for treating the local Rusyn peasants as an inferior foreign race, and the sense of privilege and entitlement which many Czechs had when they visited the region struck him as an example of imperialism. After reading a traveller's account in one of the Czech-language newspapers published in Ruthenia, Neumann responded that "the author forgets, like Czech parliamentarians and Agrarians who regard Czechoslovakia as one state, that every Czechoslovak citizen is equal in the Bohemian lands as well as in Slovakia and also in Subcarpathian Ruthenia: he forgets this and speaks like a colonial master."61 His concerns mirrored Olbracht's assessment that Czechs in Ruthenia had willingly accepted the role of "masters" and faced resentment from the local Rusyn population.

In Enciány s Popa Ivana, Neumann reproached Czech tourists who visited the far eastern corner of Ruthenia in the hope of encountering the primitive, starving Rusyn people they had

\footnotetext{
${ }^{59}$ Neumann, Československá cesta: část druhá a třetí, 140.

${ }^{60}$ Neumann, Československá cesta: část druhá a třetí, 140-141.

${ }^{61}$ Neumann, Československá cesta: část druhá a třetí, 141.
} 
read about in the Czech media. Neumann saw their wish to experience the exotic as a form of voyeur tourism: "Rakhiv isn't the poorest region of the Carpathians, but Czechs came who had read about the poverty of the Rusyn people, and they wanted to see such dramatic images. They were disappointed, because the people there aren't the living dead or falling down from hunger." ${ }^{\prime 2} \mathrm{He}$ also noted the dissatisfaction of Czech tourists in the eastern border town of Iasinia, where they hoped to "see the Orient" and felt "disappointed not to find it."

Neumann took note of the dominance of Czech commerce and the widespread use of the Czech language, just as Olbracht had observed in Země bez jména. When describing an inn in the Rusyn highlands in Československá cesta, Neumann remarked on the thoroughly Czech character of the establishment: "We noted at the time that the innkeeper was Czech, the other guests and the man who served the food were as well, and that almost all the signs and posters were in Czech or Slovak. The only sign in Rusyn was in the dining room above the door behind the bar: 'Exit'!"64 Neumann's portrayal of Rusyns as an afterthought in their own land furthered the theme of imperialism trampling on the rights of local people which Olbracht had established.

Neumann and Olbracht were not the only Manifesto of Seven authors to produce books about Ruthenia. Like Neumann, Marie Majerová would eventually publish a book about her own journey around Czechoslovakia, Výlet do Československa [Trip to Czechoslovakia], a publication for young people which included an extensive section on Ruthenia and featured a photo of Rusyn children in folk costumes on the cover. ${ }^{65}$ Vladislav Vančura's 1929 novel Poslední soud [Last Judgement] highlighted the cultural and psychological differences between the inhabitants of Ruthenia and those in the Czech capital Prague. However, among Czech left-wing authors Olbracht and Neumann provided the most significant political commentary on the state of Czech-Rusyn relations.

For Olbracht, Neumann and their literary circle, Ruthenia became an important source of artistic inspiration following their expulsion from the Communist Party. The scenic natural beauty of the Rusyn highlands and the simple way of life of its inhabitants acted as a means of escape for these Czech intellectuals who fell out of step with the changing Communist political

\footnotetext{
${ }^{62}$ Neumann, Enciány s Popa Ivana, 57-58.

${ }^{63}$ Neumann, Enciány s Popa Ivana, 114.

${ }^{64}$ Neumann, Československá cesta: část druhá a třetí, 143.

${ }^{65}$ Marie Majerová, Výlet do Československa (Prague: Melantrich, 1937).
} 
scene in Prague. Olbracht placed himself in a kind of self-imposed exile in Ruthenia, and this separation from daily politics led to the most productive and successful period of his literary career, with the Rusyn highlands acting as his muse. Neumann never lived in Ruthenia for an extended period, so his commentary on Rusyns and Ruthenia is somewhat less fully formed. Lidové noviny claimed in 1935 that Neumann's works on Ruthenia were something to "briefly skim through," while Olbracht's books contained pages which readers would "return to again and again."66 However, the critique of Czechization and imperialism as unwelcome developments in Ruthenia was strong in the works of both authors.

Olbracht and Neumann opened the eyes of Czech readers to viewing the Czech-Rusyn relationship from the Rusyn perspective, in contrast to the often negative impressions of Ruthenia offered in the media. In doing so they suggested to their Czech audience that the Rusyns were facing the same assimilationist pressures under the Czech administration that they had once faced themselves under Austrian rule. The expanding number of Czech-language schools, the prominent position of Czech as the language of administration and Czech domination of positions in the regional administration and police force were government policies which they regarded as unfairly heavy-handed. Their anti-imperialist views may have been shaped by their activities as Communists, but by humanizing the Rusyn people for the Czech reading audience, Olbracht and Neumann helped to shine a compassionate light on what had been a misunderstood and neglected corner of the Czechoslovak state. Writing in 1936, Czech academic Jaroslav Zatloukal confirmed that Olbracht and Neumann had "done the most to introduce Subcarpathian Ruthenia to the general public."67

The broader anti-imperialist movement among Czech Communists served to inform the Czechoslovak public about the inadequacy of the government's policies for Ruthenia during the economic depression of the early 1930s. Their interest in Ruthenia also stemmed from the knowledge that many of the peasant farmers of the highlands were eager converts to the Communist cause who had voted for the party in the 1920s. In depicting the actions of the Prague government and Czech officials as imperialist, Czech Communists drew parallels with other European colonial regimes who exploited the land and labour of weaker nations. Some

\footnotetext{
66 “Kniha moudrosti i lásky," Lidové noviny (27 May 1935), 5.

${ }^{67}$ Zatloukal, “Za hlubším a objektivním poznáním Podkarpatské Rusi,” 8.
} 
Rusyn intellectuals would adopt a similar tone in their struggle to achieve political autonomy and resist Czechization. 


\section{Chapter 7}

\section{The Rusyn Struggle for Autonomy}

In the second half of the 1920s Rusyn intellectuals remained divided into competing national groups, divisions which also reflected their level of dissatisfaction with the Prague government. The attitude of most Russophiles and Rusynophiles towards the central administration became confrontational in the early 1920s, with leaders Kurtiak and Gagatko calling for immediate autonomy. Leading Ukrainophiles such as Voloshyn and Mykhailo Brashchaiko remained firm supporters of their partnership with "brother Czechs" in the Czechoslovak state despite their criticism of some aspects of the regional administration. The Prague government's initial support for a Ukrainian linguistic orientation for the Rusyn people ensured that Ukrainophiles were content to keep waiting for their long-promised political autonomy. The impact of František Svojše and the "Bosnian Czechs" following their arrival on the Ruthenian political stage in 1925 served to harden the Russophile and Rusynophile autonomist position and stirred a new willingness among Ukrainophiles to show criticism of Czechoslovak government policies. Svojše's open contempt for the Rusyn intelligentsia and campaign to Czechize the Rusyn nation encouraged Russophiles, Ukrainophiles and Rusynophiles to recognize that they would have to struggle for autonomy rather than passively waiting for it to materialize.

In his groundbreaking work on Rusyn nationalism, The Shaping of a National Identity, Paul Robert Magocsi identifies the early 1930s as the period when a majority of Rusyns lost trust in the Prague government's leadership over the autonomy issue. ${ }^{1}$ However, among Russophiles and to some extent among Ukrainophiles the tipping point more likely occurred in the wake of Svojše's challenge to the Rusyn intelligentsia in the second half of the 1920s. Their resentment of Czechization forced the two sides to work together on the autonomy project, even if they could agree on little else. With Svojše cast as a symbol of Czech imperialism, the Rusyn intelligentsia woke up to the threat posed by the building of Czech schools in predominantly

\footnotetext{
${ }^{1}$ Magocsi, The Shaping of a National Identity, 211.
} 
Rusyn villages and the dominance of the Czech language in the local administration. Some Czech officials may have come to work in Ruthenia with Slavic goodwill serving as motivation, but after Svojše there were no more illusions among Rusyns that they could call all Czechs their "brothers." Rusynophile Andrei Brodii and Russophile Stefan Fentsik would later take on the mantle of freedom fighters in election campaigns in the 1930s, intent on protecting the Rusyn language, culture, and right to autonomy. The threat of assimilation, whether a concerted Czechoslovak government policy or not, served as the motivation for Rusyn autonomists to push the Prague government to fulfill the promises made in the Treaty of Saint Germain. The shift in the Rusyn view of Czech officials from humanitarian helpers to arrogant and potentially imperialist rulers by the late 1920s solidified animosity in Czech-Rusyn relations and foretold the future separation of the territory from Czechoslovakia.

\section{Opposition to Czechization}

Sidelining of the Rusyn language in administrative capacities formed one of the main complaints spurring Rusyns in their push for autonomy. Although Czech officials posted to Ruthenia were expected to learn the Rusyn language as part of their training, in practice most administrators expected the local Rusyns to communicate with them in Czech. ${ }^{2}$ In 1926 Andrei Brodii condemned Czech officials for their lack of respect for the Rusyn language:

In Rusyn territory, in Subcarpathia, everyone has rights, everyone except Rusyns. In offices the Rusyn officials are not permitted to speak in Rusyn, while Czechs can speak in German, they are even learning and speaking in Hungarian, but never in Rusyn! The Rusyn language is being extinguished, the Rusyn identity is dying. ${ }^{3}$

In a speech to supporters of his Carpatho-Rusyn Labour Party, Andrei Gagatko also spoke of the need for the status of the Rusyn language to be respected: "the law states that the Rusyn language is equal in status with Czechoslovak. Of course we can see what this is like in reality. We submit a request written in Rusyn and we receive an answer written in Czech, which we

\footnotetext{
${ }^{2}$ Jaromír Nečas, Report for President T.G. Masaryk, 18 August 1921. AÚ TGM Fond TGM-R, carton 401.

3 "Karpatskoi Rusy v Cheskom kanalî treba utopytysia...," Russkii vîstnyk (8 August 1926), 1.
} 
can't understand." Gagatko intended to rally Rusyns to the defense of their language, demanding "recognition of the Rusyn language in offices and schools [...] so that the Rusyn population can receive official notifications in the Rusyn language. In light of this, officials working in Ruthenia should also have to pass exams in the Rusyn language."

A further development in 1925 which raised concern about Czech linguistic assimilation was the threat posed by the use of the Czechoslovak Latin alphabet for Rusyn-language publications. The newspaper Novoje vremja, written in Rusyn using the Latin alphabet rather than the traditional Cyrillic, began publication in Uzhhorod with backing from the ruling Czech Agrarian Party and the support of František Svojše. Its Rusyn editor, Viktor Barany, took a progovernment stance that encouraged Rusyns to look at the positive economic and social developments which had occurred in their territory since the formation of the Czechoslovak Republic. ${ }^{6}$ The Rusyn intelligentsia quickly identified the newspaper as a threat to Rusyn language and cultural interests; Svobodnoe slovo questioned the wisdom of such "linguistic experimentation" shortly after its launch. ${ }^{7}$ Rusyn university students in Prague protested against Novoje vremja, calling the publication a form of language imperialism. Russkaia zemlia reported that the students had declared "only nearsighted people would be unable to see the danger in this action which has been inflicted on Rusyn orthography, Rusyn culture and the Rusyn soul." 8 Russkaia zemlia saw the use of Latin script as part of a broader government Czechization plot: "the next stage will be introducing the Czech language in schools, in the courts, and in the administration. Then they will have fully implemented what 'Novoje vremja' strives for: 'immersion in western culture.' This is what they want in Prague."9

Rusyn intellectuals saw defending the use of Cyrillic orthography as integral to protecting their language and culture against the creeping influence of Czech as the language of official communication. František Svojše supported Latinization of the Rusyn language as part of his Czechization campaign, drawing anger from Russkaia zemlia in defense of Cyrillic:

\footnotetext{
${ }^{4}$ Gendarme transcript from a meeting of the Carpatho-Rusyn Labour Party, village of Járok, 13 February 1927. AKPR Fond PR, carton 9.

${ }^{5}$ Gendarme transcript from a meeting of the Carpatho-Rusyn Labour Party, Village of Nižné Nystré, 11 April 1926. AKPR Fond PR, carton 8.

${ }^{6}$ For an example of Barany's support for the Prague government, see: “Administracija Podkarp. Rusi," Novoje vremja (31 December 1925), 5.

7 “Cheshskaia hazeta 'N. Vremeni' - Latynka protyv Kyrylytsŷ," Svobodnoe slovo (22 August 1925), 1.

8 "Protest protiv hazety 'Novoje Vremja'," Russkaia zemlia (9 July 1925), 2.

9 "Novaia hazeta," Russkaia zemlia (25 June 1925), 2.
} 
Get the language out of every school and office, shouts Mr. Svojše, out not only with the language, but out first of all with the orthography, out with Cyrillic. This is how this Czech refers to the Slavic script, the script which was invented by the Slavic apostles Saint Cyril and Saint Methodius, a script which is used today by the majority of Slavs. ${ }^{10}$

Rusyn concern over the introduction of the Czech language into daily life in Ruthenia was further highlighted by Russophile Nash put', which condemned the post office in Uzhhorod after a Czech employee told Rusyn customers they could address parcels only in the Latin alphabet: "All Rusyn people should give the Uzhhorod postal workers a suitable response, that in future the addresses on all parcels in Subcarpathian Ruthenia will be only in Rusyn!"11

In addition to the administrative use of Czech, the construction of Czech schools in Ruthenia was an issue which Rusyn intellectuals of all three national streams viewed as a potential danger to their cultural survival. Kurtiak's Russkii vîstnyk made a rallying cry to Rusyns in September 1926: "Rusyn people, Rusyn nation, we must save Carpathian Ruthenia from Czechization. You can see what they are doing to us, they are building Czech schools in every Rusyn village today and tomorrow and for what purpose?"12 Ukrainophiles also expressed criticism of Czech policies for the school system, while maintaining their broader support for the Prague government. Voloshyn's organ Svoboda voiced such concerns in 1927: "We are not against Czech schools where there is a cultural need for them: where there is a sufficient number of Czech children. We are not writing against Czech schools, [...] because we love Czechs as our brother nation. But we must speak up when Czech schools are used for the acculturalization of Rusyns." 13

The Communist Party's regional publication for Ruthenia, Holos zhyttia, was a particularly strident voice against Czechization of the school system in Ruthenia. It accused Czech officials of having covert motives for building Czech-language schools where there were few Czech children to attend them: "In the village of Turia-Bistra there has already been a Czech school for three years. In the entire settlement there are 2 (two) Czech children - the children of gendarmes. [...] Not far from Uzhhorod is the Ukrainian village of Vorochiv, which doesn't

\footnotetext{
10 “'Shovynystŷ!” Russkaia zemlia (15 October 1925), 1.

11 "Píšte adres Latinským pismom," Nash put' (5 November 1935), 3.

12 "Spasaite Karp. Rus' ot chekhyzatsiy,” Russkii vîstnyk (8 September 1926), 2.

13 “O Ches'kykh shkolakh,” Svoboda (12 January 1927), 1.
} 
have even one Czech child, yet it has a Czech school." ${ }^{14}$ Holos zhyttia also claimed that Czech schools formed part of the Prague government's denationalization plans throughout the republic: "Czechization of schools is occurring not only in Subcarpathia, but in all non-Czech territories of the republic. Czechization is now a basic policy of the government."15

The Rusyn intelligentsia's concerns about Czechization added urgency to their calls for the Prague government to resolve the issue of unfulfilled autonomy for Rusyns. Russophiles and Rusynophiles were particularly quick to criticize the Czechoslovak government for its inactivity on the autonomy question. In a speech to the national parliament in 1927 Gagatko expressed his dissatisfaction with the government's foot dragging: "Today our [Czech] brothers complain, 'You are unreliable, you are not mature enough for autonomy, you are dangerous for the republic,' yet before we agreed to the union we were considered good, trustworthy, mature and sensible." ${ }^{16}$ Rusynophile leader Kurtiak expressed his conviction that Rusyns had a national right to be rulers in their own territory: "We are not against any nationality in the republic, but we want to be the 'masters' in Subcarpathian Ruthenia, just like the Czechs in Czechia and the Slovaks in Slovakia." ${ }^{17}$ Kurtiak's party colleague Brodii expressed the growing divide between Czechs and Rusyns more directly, claiming that Czechs would "continue to do everything for Czech interests, so it is time that we again begin to do everything for Rusyn interests."18 Ukrainophiles also sometimes expressed frustrations over the autonomy issue; in a letter to the editor of Svoboda (Avhustyn Voloshyn), reader Avhustyn Heleban summarized the public mood among Rusyns in 1928 as "In general, boundless hatred towards Czechs."19

The growing tide of resentment against Czechization and the autonomy question finally culminated in public protests and a strike held on 8-9 February 1927 in the capital Uzhhorod. The original purpose of the protests was to express dissatisfaction with government plans to move the capital of Ruthenia from Uzhhorod to Mukacheve, and this aspect received the most

\footnotetext{
14 “Chekhizatsiia narodnoho shkilnytstva na Zakarpatti," Holos zhyttia (15 October 1929), 7.

15 "Ministr shkil'nytstva zaperechuie chekhizatsiiu Zakarpattia,” Holos zhyttia (15 January 1930), 3.

${ }^{16}$ Andrei Gagatko, Speech to the Czechoslovak national parliament, 1 July 1927, session 93.

${ }^{17}$ Gendarme transcript from a meeting of the Carpatho-Rusyn Labour Party, village of Kušnice, 18 July 1926. AKPR Fond PR, carton 8.

18 "Karpatskoi Rusy v Cheskom kanalî treba utopytysia...," Russkii vîstnyk (8 August 1926), 1.

19 “Po Uzhhorodskym svyatŷ," Svoboda (14 November 1928), 2.
} 
coverage in the Czech media in Ruthenia and the Bohemian lands. ${ }^{20}$ For Rusyns the proposal to move the capital city suggested the Prague government had an ulterior motive, a potential aim to redraw the territorial borders and place Uzhhorod within Slovakia as some Slovak nationalists demanded. ${ }^{21}$ However, the protests also took on the larger issue of government intentions to change the regional administrative system in Czechoslovakia; the consolidation plans aimed to make Ruthenia a province equivalent to other regions of the republic, which would cement the border between Ruthenia and Slovakia and make Rusyn autonomy even less likely. ${ }^{22}$ All major Rusyn leaders took part in the protests in a rare show of unity, including Ukrainophile Voloshyn, Rusynophiles Kurtiak and Brodii, Russophiles Gagatko and Kaminskii, and Communist Gáti. Czech parliamentarian Jaromír Nečas also addressed the crowds in front of the hotel Korun in support of Rusyn autonomy. ${ }^{23}$

During the protests the Central Rusyn National Council drafted a memorandum addressed to President Masaryk, government ministers and members of parliament. The memorandum, signed by Voloshyn, Kaminskii, Kurtiak, Gagatko, Brashchaiko and other leading figures, asked the Prague government to justify its continued refusal to fulfill the autonomy stipulated in the Treaty of Saint Germain and demanded a Rusyn parliament. ${ }^{24}$ Gagatko's organ Russkaia zemlia ran the huge headline "Protest against the Reduction of Our Autonomy" in its first issue after the protests occurred, ${ }^{25}$ and a later edition described the need for a "united front" among the Russophile and Ukrainophile political parties to fight the common "danger of Czechization."26

Kurtiak and Brodii's Autonomous Agricultural Union political party and its organ Russkii vîstnyk provided the strongest reaction against Czechization after the February protests. Under their leadership the party became one of the largest Rusyn political parties and the loudest voice in the struggle for autonomy. Russkii vîstnyk waged an anti-Czech campaign in every issue in the months following the protests; a particularly strong example of Kurtiak's anger took the well-

\footnotetext{
20 "Podkarpatoruský národ protestuje proti přeložení hlavního města a proti tomu, aby byl zkracován ve svých právech,” Podkarpatská Rus (11 February 1927), 1.

21 "Narod Podkarpatskoî Rusy protestue protyv nasyl'stva," Svoboda (11 February 1927), 1.

${ }^{22}$ Magocsi, The Shaping of a National Identity, 207.

23 "Protesty z Podkarpatska," Lidové noviny (9 February, 1927), 2.

${ }^{24}$ Memorandum by the Central Rusyn National Council addressed to T.G. Masaryk and members of the national parliament. 9 February 1927. AKPR Fond PR, carton 9, document PR109.

25 "Protest protyv sokrashcheniia nashe avtonomiy," Russkaia zemlia (14 February 1927), 1.

26 "Edynŷi front," Russkaia zemlia (23 February 1927), 1.
} 
known Czech motto Pravda vitězi [Truth Prevails] adopted by T.G. Masaryk and turned it against the Czechs: "Enough with Czechization! Enough with absolutism! The Czechs wrote on their coat of arms 'Truth Prevails!' We will see if we get any truth, or is truth only for them!?"27

In July 1927 the realignment of Czechoslovakia's regional administration system became law despite the protests by the Rusyn intelligentsia. Administrative Reform Act no.125 gave Bohemia, Moravia, Slovakia and Ruthenia their own provincial administrations, but these bodies remained directly accountable to the Prague government. ${ }^{28}$ Rusyn autonomists saw this development as a step backwards in their struggle for an autonomous parliament since their provincial administration remained dominated by Czechs. Gagatko addressed the national parliament during debates on the new legislation:

A full seven years have passed and the question of our autonomy not only has not moved from its original position, on the contrary the government is moving more and more decisively to restrict these rights. [...] It is like a stone lying on the heart of our nation, which seeks genuine rapprochement with the Czech nation and with the Czechoslovak Republic. [...] If we consider the terms of the peace treaty, we see that not a single one of them in the literal sense of the word has been satisfied. ${ }^{29}$

The new legislation passed in parliament and acted to enflame the Rusyn autonomy movement still further.

The lingering autonomy question was also of grave concern to the Rusyn-Americans watching events unfold across the ocean from their homeland. Their support for joining Ruthenia to Czechoslovakia had been paramount in creating the union, but since 1919 they had become mere observers rather than active participants. A Rusyn Council of National Defence formed to publicize their discontent with the treatment of Rusyns in Czechoslovakia. They approached the government in Prague, but in the words of Rusyn Council President Michael Yuhasz, their concerns were "ignored with the excuse that the autonomy for Carpatho-Russia is an internal affair of Czechoslovakia and the Carpatho-Russians of America have no right to meddle," an

\footnotetext{
27 “'Chekha vsiudŷ, a Rusyna nykuda,” Russkii vîstnyk (28 April 1927), 3.

${ }^{28}$ Peter George Stercho, Diplomacy of Double Morality: Europe's Crossroads in Carpatho-Ukraine (New York: Carpathian Research Centre, 1971), 55.

${ }^{29}$ Andrei Gagatko, Speech to the Czechoslovak national parliament, 1 July 1927, Session 93.
} 
attitude which contrasted sharply with Masaryk's openness towards them before signing the 1919 union. ${ }^{30}$ Yuhasz was especially critical of Czechization:

The Czechoslovak government continued a ruthless policy in order to disintegrate the Carpatho-Russian people ethnographically, culturally, economically, politically and in language. The forced Czechization became more intensive in every line. The Czech language was introduced into the offices, the schools and the public life day by day in increased proportions. The right of priority of the Carpatho-Russian language was ignored everywhere. ${ }^{31}$

In 1928 Yuhasz organized a petition among the Rusyn-Americans condemning the Prague government's position on autonomy and sent it to the League of Nations, which oversaw the terms of the Saint Germain treaty. ${ }^{32}$

Autonomist leader Ivan Kurtiak also visited the League of Nations in Geneva in 1928 with the intention of delivering his own petition signed by leading Rusyns from Ruthenia. Kurtiak's petition also condemned the Prague government's reluctance to grant the autonomy which the Treaty of Saint Germain guaranteed. A report by the Czechoslovak delegation to the League of Nations detected Hungarian revisionism behind Kurtiak's demands, claiming that it was “indisputable that Kurtiak's petition was sent at the behest of Hungary; this is apparent not only due to the spirit of the petition, but also the individual statements by Kurtiak, such as that the Rusyn people enjoyed greater autonomy and greater language freedom in Hungary than they do today." 33 Kurtiak's links to Hungary had already been identified by the Prague government in the early 1920s, and he was under constant police observation.

The Czechoslovak Interior Ministry prepared a report for the League of Nations in reaction to the petitions by Kurtiak and Yuhasz, outlining the Prague government's position on granting Rusyn autonomy and the steps which had to be taken before it could be fulfilled. The report highlighted the "great backwardness of the inhabitants of this land," the consequence of which was "immaturity of the inhabitants in political matters," and therefore the first activity of the Czechoslovak government had been to try and "raise the economic and cultural level in

\footnotetext{
${ }^{30}$ Michael Yuhasz, Wilson's Principles in Czechoslovak Practice: The Situation of the Carpatho-Russian People under the Czech Yoke (Homestead, Pennsylvania, 1929), 8.

${ }^{31}$ Yuhasz, Wilson's Principles in Czechoslovak Practice, 9.

${ }^{32}$ Czechoslovak delegation to the League of Nations, report draft from November 1928. AÚ TGM Fond TGM-R, carton 403.

${ }^{33}$ Czechoslovak delegation to the League of Nations, report draft from November 1928. AÚ TGM Fond TGM-R, carton 403.
} 
Subcarpathian Ruthenia." The report reaffirmed the Prague government's commitment to granting autonomy but stated that it must go "hand in hand with economic and cultural development." ${ }^{34}$ The report made no mention of a time period for granting autonomy or the irredentist accusations they held against Kurtiak.

By the late 1920s the Prague government knew that it had lost credibility among the Rusyn intelligentsia over the autonomy question and Czechization of the school system. In 1928, Jaromír Nečas outlined the potential risks posed by Czechization of the school system in a report for President Masaryk. Nečas noted that "among the local people there is much bitterness about the question of Czechization of Subcarpathian Ruthenia" and concluded that "it can only be considered detrimental to us when with excessive force the Czechization tendencies of our administration have established Czech schools on a large scale in many settlements where there are no Czech children, or where there are only a few." Brodii's party organ Russkii vistnyk spoke of the level of Czechization in the administration: "In all offices Czechs dominate, the Rusyn governor is merely a figurehead, the official language of administration is Czech, in the cities Czechs have displaced Rusyns, and in all of them Czechs are in charge." Russkii vistnyk held particular concern for the rising number of Czech officials: "From Uzhhorod to Iasinia, where before 1919 there were less than 200 Czechs, after nine years there are more than 40,000 Czechs." ${ }^{36}$

Rusyn concerns about Czechization plans are borne out by Interior Ministry reports which confirm that some government officials had considered assimilating Rusyns into the Czechoslovak nation. A 1930 report prepared for the Interior Ministry claimed that "anti-Czech" activities among Russophiles called for a process of assimilation, a step that could be justified on the grounds that "Rusyns don't have their own culture, don't have their own literature and don't have a single language, it would be best if these half-million Slavs assimilated with Czechs and Slovaks and became one branch. ${ }^{, 37}$ This opinion was also expressed in a similar ministry report from a year earlier: "Perhaps I speak against modern political ethics, but I speak from a practical

\footnotetext{
${ }^{34}$ Czechoslovak Interior Ministry document Informace pro Společnost Národi̊ o Autonomii pro Podkarpatskou Rus, 39894/1928, 18 June 1928. AÚ TGM Fond TGM-R, carton 403.

${ }^{35}$ Jaromír Nečas, Podkarpatská Rus: Zpráva posl. Ing. J. Nečase. Report prepared for President T.G. Masaryk, 13 April 1928. AÚ TGM Fond TGM-R, carton 403.

36 "8 Mai 1919 - 1928," Russkii vîstnyk (10 May 1928), 1.

${ }^{37}$ Czechoslovak Interior Ministry draft report, 1930. AÚ TGM Fond TGM-R, carton 403.
} 
position for the success of our nation and state and I can say that it would also benefit Rusyns if they became another people.",38

Rusyn intellectuals of all three national loyalties were ready to resist Czechization and the threat of assimilation by the end of the 1920s. Although they had made no progress towards the goal of achieving political autonomy, the Prague government could see that the issue of autonomy could not simply be ignored. The following decade would bring a steady increase in Rusyn pressure while the international diplomatic environment of Central Europe darkened for Czechoslovakia.

\section{The Great Depression and the Final Push for Autonomy}

The worldwide economic crisis which began in the early 1930s struck deeply in Ruthenia, and increased Rusyn discontent with the Czechoslovak government's policies. Ruthenia's reliance on a small number of industries for employment meant its economy was particularly susceptible to the downturn. In the highland villages the only dependable jobs were in timber cutting or subsistence farming, and most families survived on a mixture of both changing with the seasons. ${ }^{39}$ A 1932 Agrarian party memorandum declared that a drop in prices for produce had caused "total ruination of Subcarpathian agriculture and with it the whole economic life of this territory." 40 Social Democrat publication Hlas východu blamed the Uzhhorod administration for turning a blind eye to the crisis: "the provincial president [Rozsypal] in Galago doesn't see what is happening in the Highland, and his officials don't tell him because they are well aware that much of the poverty is the result of their paperwork."41 Rusyn Social Democrat organ Vpered also accused the Prague government's ruling party of neglecting Rusyns who were going hungry: "Which party will help our hungry people? The

\footnotetext{
${ }^{38}$ Czechoslovak Interior Ministry draft report, 1929. Document no. 1046/29. AÚ TGM Fond TGM-R, carton 403.

${ }^{39}$ Macartney, Hungary and her Successors, 235.

40 "Memorandum: Republikánské strany zemědělského a malorolnického lidu pro vládu republiky Československé," Podkarpatské hlasy (26 February, 1932), 1.

41 “Lid hladoví a páni úřadují," Hlas východu (16 April 1931), 1.
} 
Agrarians? They aren't even aware of what is happening here, they live in a peaceful paradise far away from here. We will have to look after ourselves." 42

The famine in the highlands played into the hands of the Communist Party's local branch, who sought to make political gains from the crisis. In 1933 party publication Holos zhyttia described a confrontation in the village of Sokyrnytsia near Khust where Rusyn peasants had asked Czech gendarmes to give them food to feed their starving children: "The head gendarme said: 'Throw the hungry children into the Tisa!' 'Go away women! I can't do anything for your children! You had so many of them, and they are hungry, so throw them into the Tisa river!'"43 Communist political gatherings in regional villages were not always calm; an administrative report for the Interior Ministry described a riot in a highland village where the local Rusyn peasants armed themselves with pitchforks and axes and attacked the village gendarme station, resulting in the death of at least one Rusyn when the Czech gendarmes fought back. ${ }^{44}$

The tensions created by the economic crisis of the early 1930s brought a new sense of purpose to the Rusyn autonomy movement, since some members of the intelligentsia felt they could do more for their people if they were in charge of the territory instead of Czechs. Brodii's party organ Russkii vîstnyk described this disillusionment with the Agrarians running the administration: "For fifteen years the Carpatho-Rusyn nation has had to carry the weight of the ruling Agrarian Party on its shoulders. They have brought us little but misery, and we can only imagine how different things would be if we controlled our own future." 45 Speaking to the national parliament in 1933, Brodii expressed the intense dissatisfaction Rusyns intellectuals felt with the progress of the Czech administration: "If such a situation were to arise today where the Chinese would offer to help Rusyns, then at least ninety percent of our people would be prepared to go to the Chinese.",46

Prominent Ukrainophiles also complained bitterly of Czechization and the autonomy question by the mid-1930s. Mykhailo Brashchaiko, long a reliably pro-Prague government voice among Rusyns, was ready to declare that a campaign of "ruthless Czechization" was underway

\footnotetext{
42 "Holod na Pidkarpatti," Vpered (1 February 1932), 2.

43 "Verkhnyi zhandarm kazhe: 'mechte holodnykh ditei do tysy!"” Holos zhyttia (18 June 1933), 2.

${ }^{44}$ Czechoslovak Interior Ministry document 4447/1932, prepared by the Provincial Office of Ruthenia in Uzhhorod, 12 March 1932. AÚ TGM Fond TGM-R, carton 403, document no. 482/32.

45 “Agrarŷ obîshchaiut avtonomiiu," Russkii vîstnyk (21 April 1935), 2.

${ }^{46}$ Andrei Brodii, Speech to the Czechoslovak national parliament, 27 April 1933, Session 266.
} 
in Ruthenia by 1935: "We already have hundreds of Czech schools in our purely Ukrainian villages. We have dozens of Czech public schools, we have Czech gymnasiums and teacher seminaries. ${ }^{47}$ Vpered complained about the arrogance and superiority of the Prague government in its dealings with the Rusyn nation: "They don't want to look for mutual understanding with the Subcarpathian people, they want to possess and rule over the local Subcarpathian people, and they want to place Czechs and Slovaks everywhere among us." ${ }^{48}$

Following the death of Ivan Kurtiak in 1933, two rival leaders of the autonomy movement appeared in the form of Andrei Brodii and Stefan Fentsik, who competed for the right to become the face of the Rusyn autonomy movement. Brodii and other followers of Kurtiak's Autonomist Agricultural Union party became known as the Kurtiakovtsi, while Fentsik's followers in his Russian National Autonomist Party [Russkaia natsionalno-avtonomnaia partiia] became known as the Fentsikovtsi. ${ }^{49}$ By 1935 Fentsik's party had established itself as a strong force among Russophiles and his party organ Nash put' became a major source of anti-Czech rhetoric and demands for autonomy. Fentsik also headed the Russophile cultural society Dukhnovych, which he used as a mouthpiece for pro-autonomy and anti-Ukrainophile views.

Fentsik had secured valuable funding for his party from Rusyn-Americans and the Polish government by the mid-1930s. A successful trip to the United States in 1934 earned him support from the Carpatho-Russian Union, headed by Prague-government foe Michael Yuhasz. Yuhasz supported Fentsik's drive for autonomy and funded his election campaigns and the publication of Nash put' ${ }^{50}$ Fentsik also received funding from the Warsaw government which sought to limit Ukrainian nationalism in its neighbouring territory of Galicia and supported Hungary's goal of retaking Ruthenia and creating a common border with Poland. ${ }^{51}$ Immediately after returning from America in 1935, Fentsik was arrested on charges of conspiring against Czechoslovakia after speaking openly against the Prague government in the American-Rusyn media. ${ }^{52} \mathrm{He}$ was

\footnotetext{
${ }^{47}$ Mykhailo Brashchaiko, "Bezposhchadna Chekhizatsiia," Ukrä̈ns'ke slovo (27 June 1935), 1.

48 "Chekhyzatsiini plany," Vpered (1 March 1935), 3.

49 "Fentsykovtsŷ protyv avtonomiy," Russkii vîstnyk (14 May 1935), 6.

${ }^{50}$ Magocsi, The Shaping of a National Identity, 298.

51 "Dr. S. Fentsyk i Pol'ski hroshi presovyi spir Dra Fentsyka proty 'Ukraïns'koho slova'," Ukrä̈ns'ke slovo (21 March 1935), 2.

52 “Politychna senzatsiia na Pidk. Rusy Dr. Stepan Fentsyk arestovanyi,” Ukrä̈ns'ke slovo (18 May 1935), 1.
} 
released within weeks when the government apparently decided that prosecuting him before the 1935 state elections could draw many more Rusyn supporters to his irredentist cause. ${ }^{53}$

Shortly after his release, Fentsik sought to reaffirm his claim to leadership of the Rusyn autonomy movement. In an editorial for his organ Nash put' he appealed directly to the Czech nation for change:

We protest against all forms of Czechization! We protest against the appointment of Czech inspectors in Rusyn schools. We protest against the building of Czech elementary schools in Rusyn villages. [...] Brother Czechs! We call on you for help! [...] We urge you to remove these causes of our unhappiness, so that in future we do not become enemies. ${ }^{54}$

Speaking to the national parliament a few weeks earlier, Fentsik had also addressed the Czech nation on the autonomy issue: "In 1919, sixteen years ago in the crumbling Austro-Hungarian Empire, our people were adult enough to join with fellow Slavs in the creation of the Republic. In 1919 we were politically mature enough to voluntarily join this country. [...] Now, when we have a substantial intelligentsia, educated in the Slavic spirit, we have become immature?"55

The Prague government needed to stem the rising tide of Rusyn public resentment over the autonomy question, and in May 1934 Beneš travelled to Ruthenia and gave an important speech on national unity. His words were intended to reassure Rusyns on the issue of autonomy: "The government of Czechoslovakia has never forgotten its obligations, has never forgotten what is in the peace treaty. Whatever happens autonomy will be fulfilled, just as the republic of Czechoslovakia committed to, and as it is written in the constitution. It will be implemented in the near future." ${ }^{56}$ A year afterwards, Fentsik recalled Beneš' promise of autonomy "in the near future" and asked: "What do we see in reality? [...] The commitment to grant autonomy has not been fulfilled, that's simply a fact." 57

Fentsik and Brodii both wished to be the standard bearer among Rusyn autonomists, and they often sparred with one another in print. Before the 1935 state election, Brodii sought to prevent voters from switching allegiances to Fentsik's new party by printing numerous articles in

\footnotetext{
53 “Dr. S.A. Fentsyk y Ameryk. Rus,” Nash put' (16 June 1935), 5.

${ }^{54}$ Stepan Fentsik, "Otkrŷtoe pys'mo Cheshskomu narodu," Nash put' (18 July 1935), 1.

${ }_{55}^{55}$ Stepan Fentsik, Speech to the Czechoslovak national parliament, 25 June 1935, Session 5.

${ }^{56}$ Edvard Beneš, Edvard Beneš a Podkarpatská Rus (Uzhhorod: Klub T.G. Masaryka v Užhorodě, 2006 ), 24.

57 Stepan Fentsik, "Shestnadtsat' lît," Nash put' (10 September 1935), 1.
} 
Russkii vîstnyk declaring that Fentsik's party was not truly autonomist. ${ }^{58}$ The outcome of the election was a major setback for the Prague government since $63 \%$ of the Rusyn vote went to parties considered to be anti-Czechoslovak. Brodii's autonomy party received 14\%, while Fentsik's new party attracted 9\%. The Communists drew 24\%, helped by the deplorable economic conditions which continued to plague the territory throughout the mid-1930s. ${ }^{59}$

Following these elections, the Prague government assessed the disastrous results and the deepening rift between Russophiles and Ukrainophiles and decided to support a Rusynophile orientation for Ruthenia. Observing the growing strength of the Ukrainophiles, the government aimed to find common ground between the two warring sides and try to limit solidarity between the Ukrainophiles and the Galician Ukrainians across the border in Poland. ${ }^{60}$ The policy shift began with the naming of Rusynophile Konstantyn Hrabar, a reliably pro-Prague government figure, as governor of Ruthenia. ${ }^{61}$ The decision angered both Russophiles and the generally more Prague-government friendly Ukrainophiles, who saw the support for Rusynism as a covert denationalization campaign which could result in their assimilation with Czechs and Slovaks. ${ }^{62}$ A further outcome of the elections was a boost in credibility for the Rusyn autonomists, which forced the Prague government into making solid steps towards creating a timeline for the granting of autonomy. Fentsik submitted a parliamentary bill proposing a law on Rusyn autonomy in June 1936, and in November the Central Rusyn National Council submitted a proposal to the Prague government for granting autonomy. ${ }^{63}$ Expectations rose throughout 1936 that Prague was finally beginning to act on the autonomy that it had been promising for so many years.

In 1937 the Czechoslovak government finally responded to Rusyn pressure and created a law which formed the first stage of a gradual introduction of autonomy. Law 172 provided limited additional powers for the Governor of Ruthenia, a position which at that time was still

\footnotetext{
58 “Fentsykovcŷ - ne avtonomystî!” Russkii vîstnyk (8 May 1935), 1.

59 Jan Brandejs, "Vývoj politických poměrů na Podkarpatské Rusi v období 1918-1935," in Podkarpatská Rus, Jaroslav Zatloukal, ed. (Bratislava: Klub př́átel Podkarpatské Rusi, 1936), 80-82.

${ }^{60}$ Magocsi, The Shaping of a National Identity, 228-229.

61 "Nový guvernér Podkarpatska," Lidové noviny (23 February 1935), 5.

62 "Pro nas - do nas," Ukrä̈ns'ke slovo (15 August 1935), 1.

63 "Proekt deputata d-ra Stepana A. Fentsika konstitutsii avtonomnoi Podkarpatskoi Rusi," Poslanecká sněmovna národného shromáždění republiky československé, IV. 1936. Volební období 3, zasedání 10, VI.
} 
held by Rusynophile Konstantyn Hrabar. ${ }^{64} \mathrm{He}$ and most Ukrainophiles accepted law 172 as a positive first step, though Brodii and Fentsik complained in speeches to parliament that the law was too little too late. ${ }^{65}$ The mayors of many Rusyn towns and villages sent telegrams to Czechoslovak President Edvard Beneš thanking him for granting this first stage of autonomy. ${ }^{66}$

The Prague government's new support for a Rusynophile direction in Ruthenia did not please Ukrainophiles, though they showed less hostility towards Czechoslovakia than the Kurtiakovtsi and Fentsikovtsi. Despite misgivings about the government's intentions, Ukrainophiles continued to publically show their loyalty to the state; leaflets produced by the Ukrainian cultural society Prosvita in 1937 declared, "We voluntarily joined the Czechoslovak Republic and we are loyal citizens of our democratic state,"67 while Mykhailo Brashchaiko's party organ Ukraïns'ke slovo praised the values of Masaryk and the Czech nation in March $1938 .{ }^{68}$ In a speech to parliament in the same month, Ukrainophile Iuliian Revai declared that "the inhabitants of this territory renew their trust in Czechoslovakia in these difficult times, for we are aware that the flowering of Subcarpathian Ruthenia is closely tied to the fate of the Czechoslovak Republic." ${ }^{\prime 69}$ By all accounts a majority of the Ukrainophiles remained loyal to the Prague government right until the dissolution of the republic, as they believed autonomy within Czechoslovakia offered them the best opportunity for cultural development.

Despite the Rusyn intelligentsia's distrust of Czech officials and the Prague's government's intentions, many Ukrainophiles and Russophiles held Czechoslovak President Masaryk in high esteem. Photographs and acclaim for his achievements appeared in Rusyn publications each year on his birthday, along with outpourings of grief when he died in $1937 .^{70}$ The figure of Masaryk also appeared in Rusyn poetry and songs as a great leader and benefactor right up to the final years of the union with Czechoslovakia. ${ }^{71}$ Such poems praised Masaryk for

\footnotetext{
64 "V den autonomie Podkarpatské Rusi," Národní listy (3 Ocober 1937), 2.

${ }^{65}$ Andrei Brodii and Stepan Fentsik, Speeches to the Czechoslovak national parliament, 17 June 1937, Session 106.

${ }^{66}$ A collection of these telegrams has been preserved in AKPR Fond PR, carton 12.

67 "Manifest do Ukrainskoho narodu Pidkarpattiia," Leaflet published by Prosvita, 17 October 1937.

68 “Na vrodyny Masaryka,” Ukraïns'ke slovo (9 March 1938), 1.

${ }^{69}$ Iuliian Revai, Speech to the Czechoslovak national parliament, 18 March 1938, Session 142.

${ }^{70}$ For examples see: "T.G. Masaryk," Vpered (7 March 1925), 1; "Masaryk polytyk y hosudarstvennŷi muzh," Russkaia zemlia (5 March 1925), 1; Mykhailo Brashchaiko, "Pomer Toma Masaryk," Ukrä̈ns'ke slovo (16 September 1937), 1. See also a book in praise of Masaryk's leadership by Mykhailo Brashchaiko, T.G. Masaryk iak uchitel' (Uzhhorod: Vasiliian, 1930).

${ }^{71}$ See Nedzielskij, T.G. Masaryk v Podkarpatoruském basničtví.
} 
freeing them from Hungarian rule: "our father of freedom, on your birthday we send you love from our hearts." 72 Czech academics studied the phenomenon in the 1930s and referred to it as the "Rusyn cult of Masaryk."73 Thus some Rusyns mentally separated the Slavic ideals and strong leadership symbolically represented by Masaryk from the less palatable reality of Czech administration they saw in Ruthenia.

During the first few months of 1938 the political environment in Central Europe deteriorated rapidly, giving the Rusyn autonomists hope that they could make gains from the Czechoslovak government. Sensing the government's weakness under mounting German pressure and Hungarian and Polish demands for revisionism, ${ }^{74}$ Brodii and Fentsik put aside their differences in early 1938 and agitated for autonomy as part of a new Carpatho-Russian Autonomist Union. ${ }^{75}$ In May 1938 Brodii also began to cooperate with the Ukrainophile Iuliian Revai and Russophile Agrarian Party leader Edmund Bachinskii and they convened the First Russian-Ukrainian Central National Council to pursue autonomy in earnest, requesting elections for an autonomous Ruthenian parliament. ${ }^{76}$ Bachinskii and other Rusyn Agrarians then presented the Prague government with a proposal for granting political autonomy, which won the backing of Avhustyn Voloshyn, one of the most dependable allies of the government. ${ }^{77}$

The Munich Agreement of September 1938 provided the Rusyn autonomists with the opportunity they needed to achieve their goal. Slovak autonomists led by Jozef Tiso demanded autonomy following President Beneš' resignation in the wake of the agreement, and on 6 October Tiso became Minister for Administration of autonomous Slovakia. ${ }^{78}$ Rusyn autonomists watched this development and knew the time had come for them to act as well, and Brodii, Revai and the First Russian-Ukrainian Central National Council decided to demand the same autonomous rights that Slovaks had asked for. On 11 October Czechoslovak Prime Minister Jan Syrový accepted the demands and named Brodii as Premier of an autonomous parliament for

\footnotetext{
72 Jevgenij Nedzielskij, “T. G. Masaryk v Karpatoruské písni,” in Podkarpatská Rus, Jaroslav Zatloukal, ed. (Bratislava: Klub přátel Podkarpatské Rusi, 1936), 249.

${ }^{73}$ Nedzielskij, “T. G. Masaryk v Karpatoruské písni,” 249.

${ }^{74}$ Gyula Juhász, Hungarian Foreign Policy, 1919-1945 (Budapest: Akadémiai Kiadó, 1979), 145-146.

75 "Russkie Liudy!” Russkii vîstnyk (8 May 1938), 1.

76 “Vsî Karpatorossŷv odyn avtonomnŷi tabor,” Russkii vîstnyk (1 May 1938), 1.

77 “Koalychnyky durno opravdŷvaiut sebia,” Russkii vîstnyîk (15 May 1938), 1.

78 “Avtonomiia dlia Slovachchyny,” Ukrä̈ns'ke slovo (8 October 1938), 1.; Heimann, Czechoslovakia: The State that Failed, 86.
} 
Carpathian Ruthenia. Voloshyn, Revai, Bachinskii and Fentsik were all named as ministers in the new government. ${ }^{79}$

The autonomous government of Ruthenia would last for just a matter of months until the end of Czechoslovakia in March 1939; autonomy resulted partly from international political developments, but the Rusyn intelligentsia nonetheless successfully fulfilled their long-sought goal. The achievement required Rusyns to organize themselves and actively struggle to gain autonomy, rather than waiting for the Prague government to deliver on its promise in the Treaty of Saint Germain. Fearing the plans of Czechization and imperialism expressed by Svojše in the 1920s, the Rusyn intelligentsia began to organize their demands for autonomy into a coherent movement. Russophiles and the Rusynophiles Kurtiak and Brodii always spoke loudest on the autonomy issue, but Ukrainophiles had also become more openly critical of the Prague government's policies by the end of the 1920s.

The growing strength of the Ukrainophile movement and the increasingly radical stance of the autonomist leaders Brodii and Fentsik characterized the 1930s. The success of autonomist and anti-Czechoslovak parties in the 1935 elections resulted in the Prague government switching its support from the Ukrainophiles to a Rusynophile orientation, a move that further alienated the leading Russophile intelligentsia from Prague. The lack of trust would eventually lead the Russophiles to seek political ties and financial support from Budapest and Warsaw. Although Ukrainophiles played significant roles in the struggle for autonomy, Voloshyn, Brashchaiko and other leading figures continued to express their loyalty to the Prague government and the belief that Czechoslovakia could provide them with the best opportunity to achieve autonomy and cultural development.

The Prague administration's refusal to grant the autonomy promised to Rusyns rested on the need to maintain regional stability in the broader interests of the republic. The government would only reluctantly agree to provide autonomy in 1938 when the outcome of the Munich Agreement left it with no other choice. Rusyn autonomists depicted their struggle for autonomy as a fight against Czech imperialism, a view shared by the Hungarian and Polish governments in their quest for territorial revisions. As we shall see, the Czechoslovak government was prepared

79 “Pidkarpattia maie svoiu okremu vladu," Ukrä̈n'ke slovo (14 October 1938), 1. 
to go to great lengths to defend its control of Ruthenia in the international arena due to the territory's geopolitical value. 


\title{
Chapter 8
}

\section{Defending Czech Rule: The International Campaign against Charges of Imperialism}

\begin{abstract}
Although the Prague government frequently had to deflect Rusyn criticism of its administration, a broader diplomatic battle also unfolded in the international arena. The League of Nations in Geneva held responsibility for settling disputes resulting from decisions made at the Paris Peace Conference, and they received complaints from several different opponents of Czech rule. Hungary had never accepted the loss of two-thirds of its territory in the 1920 Treaty of Trianon and established a network of organizations dedicated to the goal of revisionism. Ruthenia became an attractive target for the Hungarian irredentist cause, and memoranda sent to the League of Nations condemned the Prague government's treatment of Rusyns and refusal to grant them autonomy. Hungarian diplomats and authors worked hard in Western Europe to win support for Budapest's revisionist aims, while ethnic Hungarian and Magyarone Rusyn leaders in Ruthenia received financial help from Budapest for revisionist activities. Poland also supported and contributed to this diplomatic campaign in the hopes of regaining a common frontier with its ally Hungary. A third international group opposing Czech rule were the Rusyn-Americans, who felt they had been betrayed by the Prague government over the promise of Rusyn autonomy. By the mid-1930s these opponents were actively funding revisionist activities in Ruthenia and abroad, with the aim of painting the Czechoslovak government as power-hungry imperialists.
\end{abstract}

In response to this anti-Czech campaign, the Prague government promoted the benefits its administration had brought for Rusyns while rejecting claims of mistreatment and imperialist aims. In their own memoranda to the League of Nations, they blamed the previous Hungarian regime for the poor cultural, educational and physical condition of the Rusyn inhabitants. Propaganda publications aimed at Western audiences sought to draw attention to improvements Czech officials had made in infrastructure, education and health services. In response to the charge that Czechoslovakia had not fulfilled the terms for autonomy set in the Paris Peace Treaty, Czechoslovak diplomats argued that granting self-rule to Rusyns while they were still 
unprepared to handle such political responsibility would open the door to dangerous regional instability. As Jürgen Osterhammel suggests, an important component of liberal imperialism is that colonizers will justify their right to occupy a territory by claiming to bring justice and stability to the colonized region. ${ }^{1}$

This chapter analyzes the Czechoslovak government's defense of its policies for Ruthenia through international diplomacy and propaganda as an example of fear of imperial loss. Having invested significant financial resources in the territory and encouraged Czechoslovak citizens to view it as an integral part of the republic, the government had little appetite to surrender Ruthenia to rival powers. As the geostrategic significance of Ruthenia to the viability of the Czechoslovak state increased in the 1930s, maintaining it as a part of the republic became a priority for Czech national interests. Ruthenia's territory formed a vital link to Little Entente ally Romania, and Edvard Beneš was ready to declare by 1934 that Czechoslovakia would defend the territory "to the last drop of blood" against its rivals. ${ }^{2}$

\section{Hungary's Revisionism Campaign}

While the Treaty of Saint Germain formally united Ruthenia with the Czechoslovak republic, it was the Treaty of Trianon, signed on 4 June 1920, which forced Hungary to accept the new borders and the loss of much of its previous territory. The Hungarian government of Miklós Horthy only agreed to the treaty terms because the Allies had left them with no choice but to accept them unconditionally or face military action. ${ }^{3}$ While Czechs enjoyed statehood and a strong position in European diplomacy after the Peace Conference, Hungarians had to deal with the loss of their regional power and placement of borders which left many ethnic Hungarians under foreign rule. Resentment and refusal to accept Trianon arose throughout the Hungarian lands; on the day of the treaty signing the citizens of Budapest and regional cities

\footnotetext{
${ }^{1}$ Osterhammel, Colonialism: A Theoretical Overview, 108.

${ }^{2}$ Speech by Edvard Beneš printed in "Problém karpatoruský a jeho vztah k republice Československé," Moravská orlice (4 May 1934), 1.

${ }^{3}$ Papers and Documents Relating to the Foreign Relations of Hungary, volume 1, 1919-1920 (Budapest: Royal Hungarian Ministry for Foreign Affairs, 1939), 987.
} 
dressed in black as a sign of mourning and attended anti-Trianon demonstrations. ${ }^{4}$ Addressing ethnic Hungarians in the lost territories, Speaker of the National Assembly István Rakovszky declared that "From this moment on all our thoughts and all our heartbeats, day and night, will be directed toward the day when we can unite again in the old glory and greatness." phrase rejecting the treaty, nem, nem soha [no, no, never], became a rallying cry for revisionism. ${ }^{6}$

Numerous Hungarian irredentist organizations formed with the goal of reuniting the lost territories with Hungary, including those within Czechoslovakia. The Hungarian Frontier Readjustment League [Magyar revizios liga] and the Hungarian National Union [Magyar nemzeti szővetség] promoted the cause of irredentism in Czechoslovakia with support from the Hungarian government. ${ }^{7}$ Zsigmond Perényi, a former estate owner in Ruthenia, led the Hungarian National Union. Encouraging revisionist political movements among ethnic Hungarians in the lost territories became a basic goal of the Hungarian government, and in the words of French observer Réné Martel, the government's policy was to engineer "the maximum

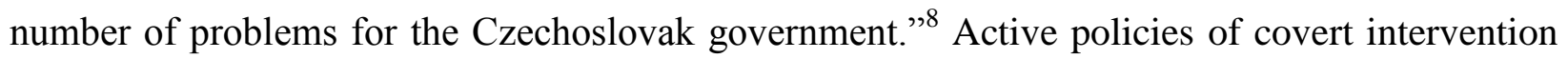
in Ruthenia included funding and support for Rusyn political parties which remained friendly towards Hungary. The Budapest government supported the Rusynophile Rusyn leaders Ivan Kurtiak and Andrei Brodii and their calls for autonomy, seeing self-rule for Rusyns as a stepping stone towards revisionism.

Czech fears of revisionist intentions among the ethnic Hungarians and Magyarone Rusyns in Ruthenia remained throughout the duration of the First Czechoslovak Republic. An ethnic Hungarian minority found itself living in the southern border regions and in the two main cities of Uzhhorod and Mukacheve. In a letter to President Masaryk in September 1919, Alois Hora claimed that the greatest revisionist danger came from "the silent organization of Hungarians, mainly higher priests, and the Magyarone intelligentsia" who outwardly promoted

\footnotetext{
${ }^{4}$ Miklós Zeidler, Ideas on Territorial Revision in Hungary 1920-1945 (New York: Columbia University Press, 2007), 36-37.

${ }^{5}$ Zeidler, Ideas on Territorial Revision in Hungary 1920-1945, 37.

${ }^{6}$ Steven B. Vardy, "The Impact of Trianon upon Hungary and the Hungarian Mind: The Nature of Interwar Hungarian Irredentism” in Hungarian Studies Review (Spring 1983, vol. 10, no. 1), 40.

${ }^{7}$ Zeidler, Ideas on Territorial Revision in Hungary 1920-1945, 108.

${ }^{8}$ Réné Martel, La Ruthénie Subcarpathique (Paris: Hartmann, 1935), 161.
} 
Rusyn autonomy "but in reality seek continuation with the enemies of the Rusyns, the old Hungarian government." 9

Among the Magyarone Rusyns, Miklós Kutkafalvy became a strong voice against Czech rule in Ruthenia. In 1919 he founded a political party of Uhro-Rusyns in Budapest and became secretary of the Hungarian government's Ministry of Minorities. ${ }^{10}$ The following year Kutkafalvy sent a memorandum to the newly-formed League of Nations, asking the League to consider the economic advantages remaining in Hungary could have for Ruthenia. He requested that the "Allied and associated powers and all the nations of the cultured world" come to the aid of the Rusyn people, labelling their inclusion in Czechoslovakia "nothing but an ill-intentioned cheat" and claimed that in just a few months Czech rule had brought "terror, famine and corruption on the people." He pointed out that the Prague government was already avoiding its obligation in the Treaty of Saint Germain to employ local citizens as officials, since they "put strangers in the offices of civil administration, who could not understand the language of our people." Kutkafalvy painted the consequences of Czech rule in stark terms, claiming that it would lead Rusyns to revolt and create "a hotbed of Bolshevism." To avoid such unrest he pleaded with the Allied powers to let Rusyns continue to live "in brotherly connection with the Hungarians" as they had done for centuries. ${ }^{11}$

The Prague government kept a close eye on the activities of Kutkafalvy and other Magyarone Rusyn activists. Vice-governor Ehrenfeld wrote to the Interior Ministry in Prague to inform them of the danger posed by Kutkafalvy, claiming that he had said publically in Budapest that Ruthenia "must return to Hungary in the near future" and that he intended to "trigger a military conflict between Hungary and Czechoslovakia" if necessary in order to achieve this aim. ${ }^{12}$ Czech daily Lidové noviny stressed the need to stamp out the danger of revisionism, claiming that the Prague government had been "far too lenient towards numerous Hungarian political agitators in Ruthenia" and suggested that Czech officials should "act with an iron fist

\footnotetext{
${ }^{9}$ Alois Hora, Personal letter to President T.G. Masaryk, September 1919. AKPR Fond PR, carton 1, document no. 2809.

${ }^{10}$ Ministry of Foreign Affairs of the Czechoslovak Republic, La Russie Subcarpathique au point de vue de la question des nationalités (Prague: Orbis, 1922), 16.

${ }^{11}$ Miklós Kutkafalvy, Memorandum of the Ruthenians of Hungary to the Allied and Associated Powers and to all the Nations of the Cultured World, 1920.

${ }^{12}$ Petr Ehrenfeld, Administrative Document for the Interior Ministry, document no. 9438, 22 May 1922. AKPR Fond PR, carton 4.
} 
against the pro-Hungarian agents and expel them to Budapest." ${ }^{13}$ Meanwhile České slovo declared that Ruthenia was "awash with agents of the Hungarian government" who were intent on "organizing irredentist actions in order to join Ruthenia to Hungary."14

The ethnic Hungarians working in the administration in Ruthenia formed another concern for the Prague government. A Czechoslovak Interior Ministry report from October 1919 claimed that the biggest risk to stability lay among "the Hungarian teachers, priests and notaries" who "tell the Rusyn people that Czechs will be expelled by Hungarians and Poles in a few weeks and that all of Ruthenia will join Hungary." The author called these Hungarians "pests" and lamented that the Czechoslovak state should have to employ and pay such people who were actively working against it. ${ }^{15}$ A demonstration in favour of Hungary in Uzhhorod in February 1921 drew a crowd of 400 to hear speeches by Ruthenian Hungarian leader Egry Ferenc; when Czech gendarmes tried to calm them the crowd shouted, "You can't prevent it, Ruthenia will be Hungary, Slovakia will be Hungary.” The Czech Agrarian Party newspaper Venkov characterized the anti-Czech demonstration as a "Hungarian and Jewish" rally, though Iosif Kaminskii and other Magyarone Rusyns also attended. ${ }^{16}$

Czech officials saw the Hungarian-language media in Ruthenia as a particularly dangerous threat to stability. The Hungarian-language newspapers such as Uzhhorod's Magyar hírlap became sources of irredentist sentiment which had to be closely watched and censored. Prague's Národní listy wrote of the revisionist danger posed by the Ruthenian Hungarianlanguage newspapers in 1921, claiming that "censorship should be far stricter, since not even the most corrupt journalist would attack our state so villainously and agitate so shamelessly for a return to Budapest as the Hungarian patriots." ${ }^{17}$ Lidové noviny reported on Czech attempts to clamp down on the distribution of Hungarian revisionist publications in 1923:

The speed and success of the operation by the police force in Uzhhorod, which removed the mask of Hungarian irredentism, has surprised and intimidated the Hungarians. [...] Once they get over their surprise they will again incite hatred

\footnotetext{
13 “Nebezbečné věci na Podkarpatské Rusi," Lidové noviny (6 November 1921), 2.

14 “Vážné nebezpečí polsko-madarských úkladů," Večerné České slovo (24 November 1920). ANM Fond Starý, carton 1 .

${ }^{15}$ Interior Ministry document no. 14979, 30 October 1919. AÚ TGM Fond TGM-R, carton 400, document no. D 5069.

16 “Madarsko-židovská demonstrace proti republice," Venkov (1 March 1921), ANM Fond Starý, carton 1.

17 “V Podkarpatske Rusi,” Národní listy (11 January 1921), 1.
} 
against the republic and its institutions. Now it is up to the Prague government to negotiate with Hungary, which must be held accountable for the crimes of its underlings. $^{18}$

The Hungarian-language journals in Ruthenia also became firm supporters of Rusyn autonomy, with the expectation that this would help to hasten the region's return to Hungary. Lidové noviny fretted about the Rusyn autonomy question and the role of the Hungarian media in promoting this agenda in the name of revisionism: "All the Hungarian newspapers in Uzhhorod and Mukachevo are enthusiastic warriors for the autonomy of Subcarpathian Ruthenia."19

Czech officials were quick to point out the geostrategic importance of Ruthenia as grounds for defending it against Hungarian revisionism. The territory provided a vital territorial link with Little Entente allies Romania and Yugoslavia. Václav Drahný claimed in a 1921 government publication that "without Ruthenia we will be an island surrounded by an enemy sea, we will be separated from the eastern Slavic world and friendly Romania." ${ }^{20}$ Josef Pešek, the head of Ruthenia's school system, declared in the same year that Ruthenia was "protection for Slovakia, because it prevents the union of Poles and Hungarians which would threaten our Slovaks." ${ }^{21}$ These were quite different views than the one expressed by President Masaryk in 1919; he had told Hungarian minister Oszkár Jászi that "the Czechoslovak nation” would be prepared to consider "a more just and equitable rearrangement of the frontiers" in the event that "a democratic government should be established in Hungary." 22 Clearly the government's thinking on Ruthenia's strategic value had changed significantly after just two years of Czech administration in Ruthenia.

A new source of criticism of Czech rule appeared in 1921 in the form of the RusynAmericans. Following Gregory Zhatkovych's resignation as Ruthenian governor, he returned to the United States full of anger at the way he had been treated by the Prague government. Eager to inform the world that Czechoslovakia had not fulfilled its obligation to grant autonomy as stipulated in the Peace Treaty, he published a book which outlined his main grievances. Attacking the government's inability to compromise on the autonomy question, he claimed he

\footnotetext{
18 “Pumové útoky v Užhorodě,” Lidové noviny (13 February 1923), 3.

19 “O židovskou kancelář na Podkarpatské Rusi,” Lidové noviny (20 May, 1923), 3.

${ }^{20}$ Drahný and Drahný, Podkarpatská Rus, její př́rodni a zemědělské poměry, 6.

${ }^{21}$ Josef Pešek, Kulturni poméry a osvětová práce v P. Rusi (Prague: Orbis, 1921), 5.

22 Oscar Jászi, "Dismembered Hungary and Peace in Central Europe,” Foreign Affairs (15 December 1923 ), 279.
} 
could "not accept and never will accept the centralization and blindly chauvinistic bureaucracy, the two factors which are the main cause of the terrible situation Ruthenia finds itself in today." Employing a phrase he attributed to British Prime Minister Lloyd George, Zhatkovych said that Rusyns had asked only for "fair play" and that he had done everything possible to build a viable working relationship with Czech officials. ${ }^{23}$

Zhatkovych began a campaign in America to spread awareness of the Rusyn autonomy issue and Czech dishonesty, a development which the Prague government watched closely. Reports for President Masaryk by Nečas highlight concerns that close contact between RusynAmericans and Slovak-Americans could spread Zhatkovych's anti-Czech sentiment among them, potentially exporting it to Slovaks and Rusyns in Czechoslovakia through their publications. Nečas gave recommendations for minimizing the potential damage in Ruthenia resulting from Zhatkovych's campaign, such as ensuring workers in the emigration offices who mediated contact between Rusyns in Ruthenia and those in America were "safe hands" who could be relied upon to "work in the republic's interests." Rusyn-American publications were to be banned from shipment to Czechoslovakia to prevent them reaching the Rusyn intelligentsia. He also suggested that the Czechoslovak press bureau in Washington should keep watch for any damaging statements Zhatkovych made in the US media, and be ready to publish a counteroffensive if necessary. ${ }^{24}$

In 1922 the Allied powers attending the Genoa Conference received complaints against the Czech administration in Ruthenia and the Prague government's refusal to grant Rusyn autonomy. These accusations came in the form of letters from the Rusyn-Americans, Kutkafalvy and the Magyarone Rusyns, and Gagatko and the Russophile Rusyns. ${ }^{25}$ Summarizing these complaints in a report for President Masaryk, Nečas felt the most difficult to contradict would be Kutkafalvy's assertion that regional and state elections had yet to be held in Ruthenia, when they had been guaranteed under Hungarian rule. He concluded that Kutkafalvy's claim showed close coordination with "the constantly repeated Hungarian arguments," which the Ministry of Foreign

\footnotetext{
${ }^{23}$ Zhatkovych, Expose Dr. G.I. Žatkoviča, 43.

${ }^{24}$ Jaromír Nečas, Paralysování činnosti Žatkovičovy v Americe, Report prepared for President T.G. Masaryk, 2 December 1921. AÚ TGM Fond TGM-R, carton 401.

${ }^{25}$ Jaromír Nečas, Stižnosti proti Čsl. republice na mezinárodním foru, Report for President T.G. Masaryk, 1922. AÚ TGM Fond TGM-R, carton 402.
} 
Affairs would "again officially deny" while confirming for the League of Nations that elections would be held as soon as possible. ${ }^{26}$

Following these complaints in 1922, the Prague government prepared a more decisive diplomatic offensive against foreign criticism of its policies in Ruthenia. A memorandum targeted at a Western audience titled Mémoire Concernent la Russie Subcarpathique praised the judgement of the Peace Treaty in assigning Ruthenia to Czechoslovakia and highlighted the many improvements for Rusyns since the end of Hungarian rule. ${ }^{27}$ The memorandum text, prepared by the foreign ministry, stated that in 1919 Czechoslovak officials had found Ruthenia "in complete administrative and economic disorder" and claimed that despite these challenging conditions, preparations were still being made for parliamentary elections and for autonomy in the near future. Wishing to draw a clear line between the caring attitude of the Czechoslovak government and the supposedly neglectful behaviour of the Hungarian government, the memorandum called their approaches "complete opposites." While Hungary had shown "complete indifference" towards the Rusyns, the report claimed Czechoslovakia wished to improve education and living standards for a fellow Slavic nation and to give them back "human dignity.",28

After the flurry of diplomatic volleys by the Prague government and its detractors, the League of Nations felt obliged to look further into the matter. In 1923 the League sent an envoy from the Minorities Section of the Secretariat, Dr. Pablo de Azcárate from Spain, to assess the conditions of the Rusyns under Czech rule. Nečas organized his visit and said that the government would endeavour to show Azcárate "every side of life in Ruthenia" and to be "as objective as possible" in showing him the reality of conditions there. ${ }^{29}$ A progress report simultaneously submitted to the League of Nations by the Czechoslovak foreign ministry promoted the efforts of officials to improve public health, education and regional infrastructure in Ruthenia after the "negligence" of the Hungarian regime. The report stressed the Prague government's commitment to "making every effort to quickly prepare for elections in Ruthenia

\footnotetext{
${ }^{26}$ Jaromír Nečas, Stižnosti proti Čsl. republice na mezinárodním foru, Report for President T.G. Masaryk, 1922. AÚ TGM Fond TGM-R, carton 402.

${ }^{27}$ Ministry of Foreign Affairs of the Czechoslovak Republic, Mémoire concernent la Russie Subcarpathique: territoire ruthène du sud des Carpathes (Prague: Orbis, 1921), 5.

${ }^{28}$ Ministry of Foreign Affairs of the Czechoslovak Republic, Mémoire concernent la Russie Subcarpathique, 38.

${ }^{29}$ Jaromír Nečas, Učel cesty Prof. De Azcarate, Report prepared for President T.G. Masaryk, 1923. AÚ TGM Fond TGM-R, carton 402 .
} 
and for autonomy in Ruthenia as stipulated in the Saint Germain treaty." 30 Azcárate's report gave a generally favourable assessment of the Czech administration's progress, agreeing that under the present conditions autonomy could not be granted immediately. ${ }^{31}$

Azcárate had changed his positive opinion of Czech progress in Ruthenia by 1928 . He sent a letter to the Czechoslovak government which criticized their lack of progress in fulfilling the obligation to grant the Rusyns autonomy. He asked why the Prague government had not taken the necessary steps to fulfill Czechoslovakia's obligation. ${ }^{32}$ A Czechoslovak interior ministry report reacted to Azcárate's letter by calling the Rusyn autonomy question "our Achilles heel in Geneva" which had become a "weak point" for the republic's enemies to exploit. ${ }^{33}$ In response to his questions on the autonomy issue, the interior ministry recommended highlighting the potential danger of a Bolshevik government forming in Ruthenia if an autonomous parliament came into existence. Searching for a historical precedent to bring before the League of Nations, the report recommended comparing the case of the Rusyns of Czechoslovakia to that of the Philippines under US rule; the United States had argued during Woodrow Wilson's administration that it was "not possible to grant Filipino autonomy" because the population was "not yet able to govern themselves" and needed education before they would be ready. ${ }^{34}$ Such a comparison suggested that the Prague government viewed Ruthenia in legal terms as a colonial entity, while reflecting Jürgen Osterhammel's view that compassionate colonialism is presented by the colonizers as a system of education for future self-rule.

Many irredentists also accused the Czech administration of mistreating the Hungarian minority in Ruthenia. In 1925, the Organization of Hungarian Journalists in Czechoslovakia [Organisaci mad'arských žurnalistů v Československu] sent a memorandum titled "Ruthenia in the Mirror of Truth" to President Masaryk to criticize what they saw as non-democratic treatment

\footnotetext{
${ }^{30}$ Kamil Krofta, Mémorandum du Gouvernement Tchécoslovaque: Territoire Autonome des Ruthenes au sud des Carpathes, Memorandum of the Czechoslovak Ministry of Foreign Affairs (15 September 1923), 39.

${ }^{31}$ Krofta, Mémorandum du Gouvernement Tchécoslovaque: Territoire Autonome des Ruthenes au sud des Carpathes, 39.

${ }^{32}$ Dr. Pablo de Azcárate, letter to the Czech Delegation to the League of Nations, 10 March 1928. AÚ TGM Fond TGM-R, carton 403.

${ }^{33}$ The Czechoslovak Delegation to the League of Nations, Podkarpatská Rus, 1928. AÚ TGM Fond TGM-R, carton 403.

${ }^{34}$ Czechoslovak Interior Ministry document Informace pro společnost národů o autonomii pro Podkarpatskou Rus, document no. 39894/1928, 18 June 1928. AÚ TGM Fond TGM-R, carton 403.
} 
of ethnic Hungarians by the Czechoslovak state. ${ }^{35}$ The Hungarian government supported these views and spread them to an international audience through propaganda mouthpieces such as the English-language Danubian Review, produced by Budapest newspaper Pesti hirlap. The journal expressed similar opinions of the condition of ethnic Hungarians, claiming that "the Czechs have at all times shown unbounded hatred for the Magyars and treated them - as members of a foreign race - with all the arrogant haughtiness of 'victors'." condemning the attitude of officials towards ethnic Hungarians, declaring that "Czech gendarmes regard as their principal duty, not the detection of crime, but the supervision of the elements classed as politically 'unreliable' - the Slovaks and Ruthenians and more particularly the Magyars. ${ }^{\circledR 37}$ The inclusion of Slovaks in the list reflected an intention to paint Czechs as tyrants who placed themselves above all others within the republic.

Distrust of the Hungarian minority in Ruthenia and its ties to the Hungarian government was a popular theme in the Czech-language press. Podkarpatská Rus claimed in 1926 that Hungarian irredentism in the territory was "paid for with money from Hungary," ${ }^{, 38}$ while Tribuna suggested that through Hungarian influence "one million pounds sterling" had been transferred from British banks to Uzhhorod to help fund the Magyar irredentist movement. ${ }^{39}$ In response to a memorandum by Ruthenian Hungarians demanding more rights in 1928, Národní politika claimed that "Hungarians in Czechoslovakia have more freedoms and rights than their brothers in Hungary" while Hungarians in Ruthenia could "freely propagate their language, culture and arts without restrictions. ${ }^{" 40}$ The Prague government remained more diplomatically neutral when describing the Hungarian minority publically, though in a 1928 government memorandum for the League of Nations Beneš bluntly declared that "our Hungarian neighbours do not hide their aspirations to change the new situation in Central Europe... It is in this spirit that Hungarian

\footnotetext{
${ }^{35}$ Organisaci mad’arských žurnalistů v Československu, Podkarpatská Rus v zrcadle pravdy, Memorandum sent to President T.G. Masaryk, 1925. ANM Fond Brandejs, carton 1.

36 "Struggle of Hungarians in Czecho-Slovakia," Danubian Review (May 1938, vol. 5, no. 12), 13.

37 "Struggle of Hungarians in Czecho-Slovakia," Danubian Review (May 1938, vol. 5, no. 12), 22.

${ }^{38}$ Podkarpatská Rus (9 January 1926), 2.

39 “Milion liber šterlingů na mad’arisování Podk. Rusi,” Tribuna (27 April 1927). ANM Fond Starý, carton 1.

40 "Nad čím by se měl zamysliti Anglický Lord Rothermere," Národní politika (8 June 1928), 1-2.
} 
agitation has been initiated in Ruthenia, an intention which is also maintained by the Rusyn Kutkafalvy.",41

In 1927 the Administrative Reform Act no.125 which gave Ruthenia the legal status of a province provided further reason for Hungary to claim that the Prague government had forgotten its commitment to provide Rusyns with autonomy. Hungarian publications reacted to this administrative change as further evidence that Czechoslovakia had no intention of granting autonomy. Danubian Review concluded that the law "seriously injured" the Rusyn autonomy movement as it locked Ruthenia into the same administrative structure as the other provinces of Czechoslovakia, while the Treaty of Saint Germain had promised Rusyns "a different form of public administration and autonomy, more independent than that of the other territories of Czechoslovakia." 42 In a collection of propaganda essays compiled by Hungarian Count Albert Apponyi in 1928, Justice for Hungary, György Lukács claimed that Rusyns had "always desired to remain with the Hungarians" and that "Czechs have never given the Ruthenians the autonomy prescribed by the Peace Treaty, and have never even promised it for the future. What is this but a violation of the Peace Treaty?"43

Hungarian revisionists also found influential backers in countries considered friendly towards Czechoslovakia. In 1927 the movement received a significant boost when the English Viscount Rothermere (Harold Harmsworth) became a firm supporter of Hungary's intention to reclaim its former territories lost in the Treaty of Trianon. ${ }^{44}$ Rothermere controlled the Daily Mail and Daily Mirror newspapers, and this large readership gave him a broad platform for expressing his political opinions. In June 1927 Rothermere wrote "Hungary's Place in the Sun," an article in the Daily Mail supporting Hungary's revisionist goals, the first of many such proHungarian publications in his newspapers. ${ }^{45}$ Rothermere claimed that permitting revisions to the Trianon Treaty was "no more than elementary justice" since Hungary had "a perfectly righteous and reasonable claim to recover the territories preponderantly inhabited by Hungarians" who remained "cut off from all intercourse with her by every device that the malevolence of her

\footnotetext{
${ }^{41}$ Edvard Beneš, Memorandum for the League of Nations, 1928. Text of the memorandum included in: Réné Martel, La Ruthenie Subcarpathique (Paris: 1935), 73-74.

42 “The Ruthenians' Struggle for Autonomy," Danubian Review (August-September 1938, vol. 3, no. 4), 21.

${ }^{43}$ György Lukácz, "The Injustices of the Treaty of Trianon," in Justice for Hungary: Review and Criticism of the Effect of the Treaty of Trianon, Count Albert Apponyi, ed. (London: Longmans, Green and Co., 1928), 149.

${ }^{44}$ Juhász, Hungarian Foreign Policy, 1919-1945, 85-86.

${ }^{45}$ Viscount Rothermere, My Campaign for Hungary (London: Eyre and Spottiswoode, 1939), 8.
} 
neighbours can invent. ${ }^{, 46}$ Rothermere specifically referred to Ruthenia's "arbitrary amputation" from Hungary, and felt that under Czech rule it had become "the most depressed and povertystricken area in Central Europe. ${ }^{~} 47$ Rothermere's support was warmly welcomed in Hungary and provided further encouragement to the Hungarian minority in Ruthenia.

Czechs and Rusyns loyal to the Prague government treated Lord Rothermere's support for Hungary as a serious danger. Prague daily Národní politika called his campaign "an attack on the peace and security of all of Central Europe, ${ }^{, 48}$ while Czech author Richard Dušek accused Rothermere of turning a blind eye to Czech progress in Ruthenia:

Lord Rothermere is calling for the return of Subcarpathian Ruthenia and Slovakia to the former incompetent system of rule, a system of illiterate mayors in the villages and corrupt notaries. It would be advantageous if foreigners could compare the excellent administration of Czechoslovakia with the former Oriental administration, so that they could see the difference and the amazing progress of the local people, and the massive effort made by hundreds and hundreds of the Czech intelligentsia there. ${ }^{49}$

The ruling Czechoslovak Agrarian party organized public rallies in Ruthenia against Lord Rothermere and his support for revisionism. A report on the protests for the Interior Ministry reveals that Ukrainophile Rusyns loyal to Czechoslovakia such as Avhustyn Voloshyn gave speeches denouncing Rothermere's campaign. Dr. Avhustyn Shtefan declared "Lord Rothermere, get your hands off of us!" to applause from the crowd, and Iulii Brashchaiko, brother of Mykhailo, announced that he had sent a telegram of protest to Lord Rothermere. ${ }^{50}$ Kaminskii called Rothermere's support for border realignment a threat to Ruthenia's existence: "The Carpatho-Rusyn nation strongly protests against the actions of Lord Rothermere, because without the territory with Hungarian citizens Ruthenia cannot stand on its own feet." ${ }^{51}$

Rothermere's support for revisionism had a significant impact on the irredentist movement in Hungary yet his opinions were not widely shared in British society or in government. Although his newspapers had large circulation numbers, they targeted an audience

\footnotetext{
${ }^{46}$ Rothermere, My Campaign for Hungary, 34.

${ }^{47}$ Rothermere, My Campaign for Hungary, 15.

48 "Bratr proti bratru," Národní politika (23 July 1927), 1.

${ }^{49}$ Dušek, Podkarpatská Rus jindy a nyní, 3-4.

${ }^{50}$ Gendarme report for the Czechoslovak Interior Ministry, Protesty proti akci Rothermerevě, 4 September 1927. AKPR Fond PR, carton 9, document PR 365.

${ }^{51}$ Iosif Kaminskii, quoted in "Protesty protiv akciji lorda Rothermere," Novoje vremja (31 July 1927), 1.
} 
which was disconnected from such foreign political matters. Scottish academic R.W. SetonWatson, who held considerable influence in shaping British foreign policy on Central European issues, told President Masaryk that Rothermere was "not representative of English public opinion" while declaring that "the masses are not in the least interested in Central Europe.",52

Meanwhile Hungarians praised and rewarded Rothermere for promoting their national cause. He recieved many commendations and city streets were named in his honour, ${ }^{53}$ while the Hungarian general public sent so many gifts to his home in London that a special room was required for their display. ${ }^{54}$ His pro-revisionist articles led directly to the founding of the Hungarian Revisionist League, an organization which sought to attract interest and sympathy in Western Europe for the irredentist cause. Additional support from Britain would come in the 1930s when academic C.A. Macartney declared that "the course most advantageous to the Rusyns themselves" would be to "return the whole district to Hungary.",55

Support for Hungary's anti-Czech campaign also came from the Rusyn-American Council of National Defense in Pennsylvania, an organization which Prague gazette Národní listy claimed to be "firmly in the service of Hungarian propaganda." 56 The league's President Michael Yuhasz made complaints to the League of Nations and the Prague government about the Rusyn autonomy issue. A 1928 memorandum addressed to the "Allied and Associated Powers" of the League of Nations condemned Czech attempts to assimilate Rusyns, claiming that the Rusyn nation "prefer that their children remain 'backward' Ruthenes than become 'progressive' Czechs." ${ }^{57}$ An appeal to President Masaryk in 1929 pleaded with the Czech government to respect its commitment to provide Rusyns with autonomy, while a memorandum from the same year declared that "the Czechs must be checked" as they were "unfit to rule over other people" and the "oppressed minorities must be delivered from their bondage." 58 Yuhasz travelled to

\footnotetext{
${ }^{52}$ R.W. Seton-Watson, "The Situation in Slovakia and the Magyar Minority," Memorandum for President Masaryk, 1928. Reprinted in: R.W. Seton-Watson and his Relations with the Czechs and Slovaks, Documents 1906-1951, Jan Rychlík et al, eds. (Banská Bystrica: Matica Slovenská, 1995), 410.

${ }^{53}$ Miklós Zeidler, Ideas on Territorial Revision in Hungary, 1920-1945 (New York: Columbia University Press, 2007), 109.

${ }^{54}$ Zeidler, Ideas on Territorial Revision in Hungary, 1920-1945, 245.

${ }^{55}$ Macartney, Hungary and her Successors, 247.

56 “Menšinová komise S.N. o Podkarpatské Rusi," Národní listy (31 December 1933), 5.

57 The American Rusin Council of National Defence, Memorandum to the League of Nations and Governments of Allied and Associated Powers as Signatories of the Peace Treaties of St. Germain en Laye, September 1928.

${ }^{58}$ Yuhasz, Wilson's Principles in Czechoslovak Practice, 61.
} 
Geneva in 1932 to address the League of Nations in person with his complaints on behalf of the Rusyn-Americans. In response to Yuhasz's accusations of mistreatment and the unfulfilled promise of autonomy, Beneš claimed that the government's answer to his complaints had been "examined in detail by a commission of the League of Nations council, which included delegates from England, France and Mexico, and their official report reconfirmed their satisfaction with our republic's administration."

The Hungarian revisionist cause found another strong ally in the government and media of Poland. The Warsaw government wished to support the revisionist aspirations of its close ally Hungary and the formation of a Polish-Hungarian border. Czech control of the former Polish region of Těšín in Silesia left a further grievance against the Prague government which Poles hoped to rectify. ${ }^{60}$ Polish diplomat and former foreign minister Leon Wasilewski expressed dissatisfaction with Czech control of Ruthenia in 1927, declaring that the Prague government had targeted the region for assimilation and "flooded it with Czech officials and the Czech language." He claimed that while "30,000 Rusyn children” were still in need of schools, Czech schools were being quickly built, whose "basic purpose is Czechization."61 Links between Ukrainian nationalists in Ruthenia and Galicia also troubled Polish gazette Kurjer Warszawski in 1932: "For Poland the question is significant, because Subcarpathian Ruthenia is a territory which could provide help to anti-Polish Ukrainian saboteurs, as has already frequently occurred." 62

The Czech press and the Prague government distrusted Polish intentions, while hoping that some common ground could be found with a fellow Slavic nation. In 1929 Narodní politika claimed that Poland considered Czech control of Ruthenia to be uncertain:

In the eyes of Polish politicians Subcarpathian Ruthenia is today a territory with an unstable internal situation. [...] In Polish eyes the question even emerges of whether Subcarpathian Ruthenia will remain a part of Czechoslovakia forever. ${ }^{63}$

\footnotetext{
${ }^{59}$ Edvard Beneš, "Podkarpatská Rus s hlediska zahraničně-politického,” Podkarpatská Rus, Jaroslav Zatloukal, ed. (Bratislava: Klub přátel Podkarpatské Rusi, 1936), 18.

${ }^{60}$ Kevin Hannan, Borders of Language and Identity in Teschen Silesia (New York: Peter Lang, 1996), 53.

61 “Polský Ministr o Podkarpatské Rusi," Národní listy (8 January 1927). ANM Fond Starý, carton 1.

62 “Polský tisk o Podkarpatoruské autonomii,” Podkarpatská Rus (28 January 1932), 5.

63 “Polské zájmy o Podkarpatskou Rus,” Národní politika (4 July 1929), 1.
} 
In 1934 Plzeň gazette Český deník called on the Polish government to remember their shared Slavic roots, lamenting that "Czech-Polish relations are not as they should be between neighbourly Slavic nations!" Český deník also called on the Prague government to "gravitate towards Poland," since this would be "in the Czech interest." ${ }^{64}$ Czech MP František Lukavský also attacked Polish politicians for neglecting Slavic ties in their plans for Ruthenia: "This land is mostly Slavic, but despite this they want to throw the Slavs of this land back into Hungarian servitude and poverty, the way it was before!"65

Czech fears of revisionism in Ruthenia were so great that even trusted ally and Little Entente member Romania received accusations of harbouring territorial ambitions. In 1927 National Democratic Party organ Národní listy reported that Romania was "agitating for the division of Subcarpathian Ruthenia between Poland and Romania." ${ }^{66}$ According to Národní listy "biased reports" had appeared in Romanian newspapers which claimed that "Czechoslovakia is unable to maintain the necessary authority in Subcarpathian Ruthenia," thus resulting in an increase in Bolshevism and unrest in the territory. Národní listy considered this an act of betrayal by a country deemed to be a loyal partner of Czechoslovakia, calling it "embarrassing" that such a desire should be expressed "in the media of our friend and ally Romania" and encouraged the Romanian state "to give up any such aspirations.",67

\section{Captions for Figure 8.1 (following page)}

1. Minister: "We are a peace-loving nation, a democratic nation!"

2. We are not fundamentally opposed to giving neighbouring Germany the territory inhabited by Germans -

3. - and also in the interests of justice towards Poland we want to express a willingness to give part of the border to them -

4. - Neither can Romania say that we are a selfish and stubborn state and Subcarpathian Ruthenia -

5. - Hungary and Austria shall also receive some border adjustments -

6. - Good God, where is the Czechoslovak republic?

\footnotetext{
64 “Poláci proti naši Podkarpatské Rusi," Český deník (23 December 1934), 2.

${ }^{65}$ František Lukavský, "O Podkarpatské Rusi," Český deník (19 February 1935), 1.

66 “Kerenština ohrožuje naší Podkarpatskou Rus!” Národní listy (6 April 1927), 1.

67 “Kerenština ohrožuje naší Podkarpatskou Rus!” Národní listy (6 April 1927), 1.
} 


\section{Figure 8.1 - "We Are a Peace-Loving Nation" (1927)}

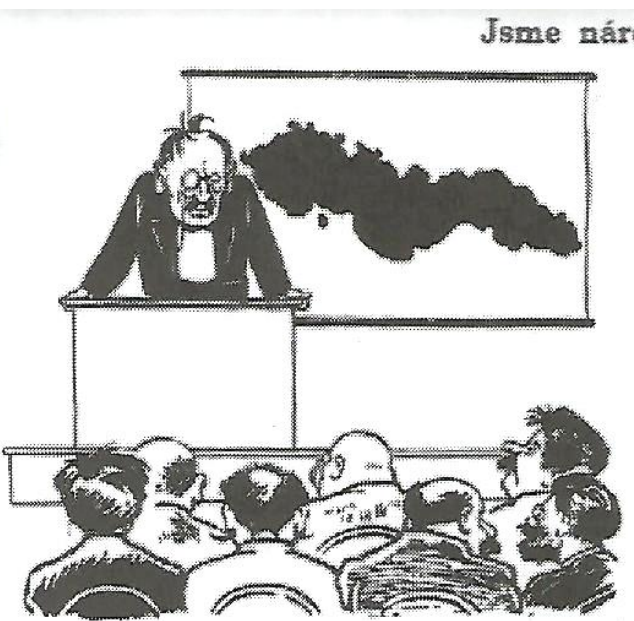

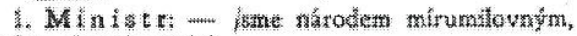

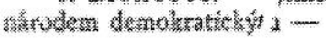

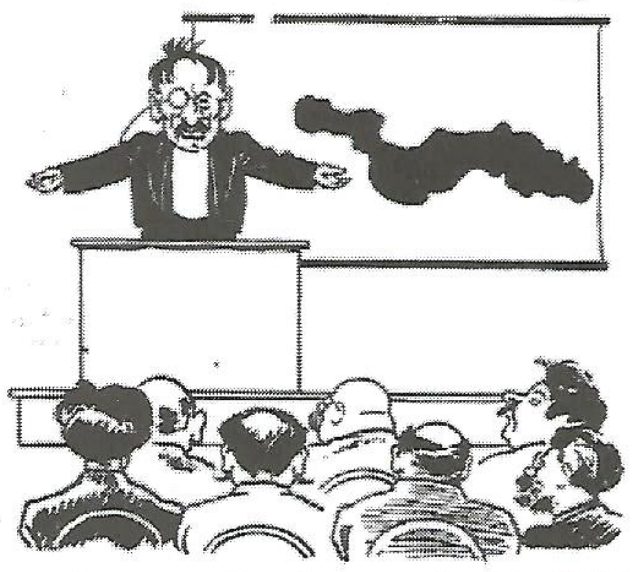

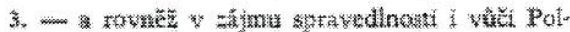

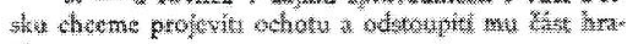
witie

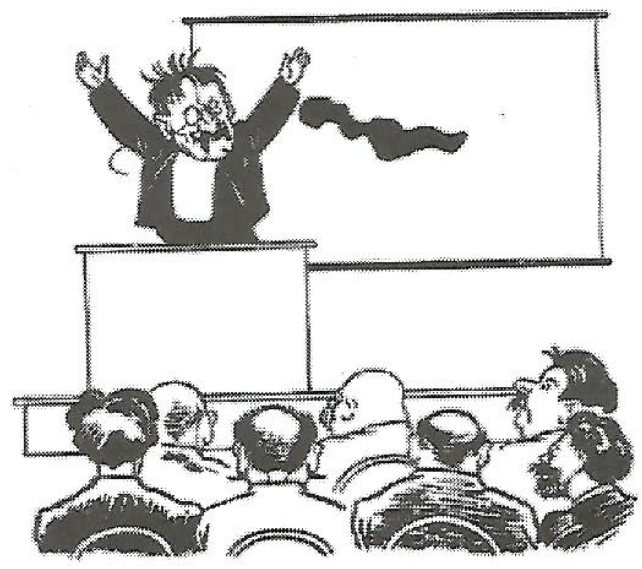

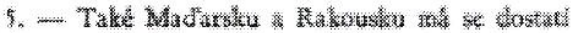

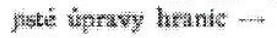

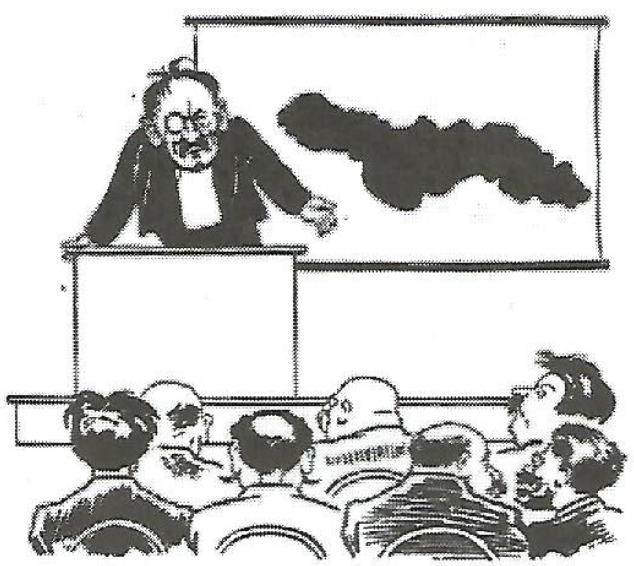

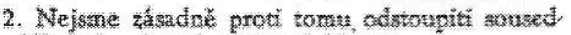

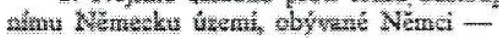

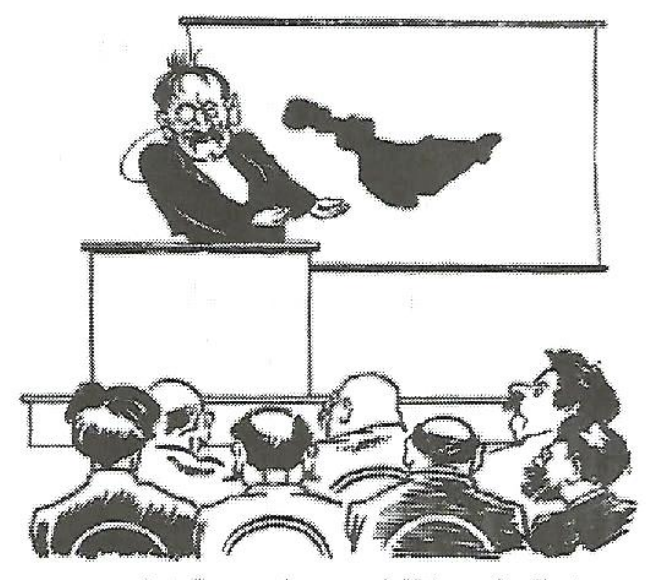

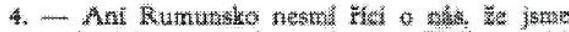

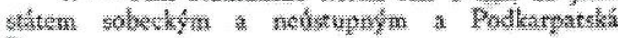

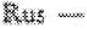

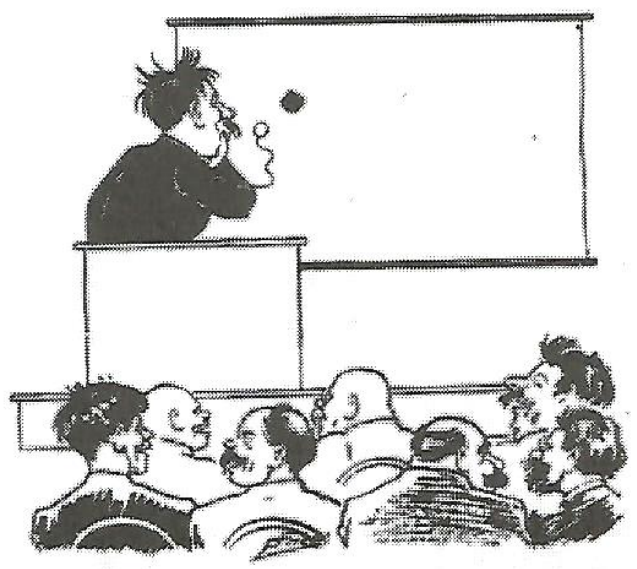

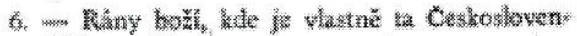

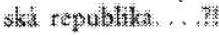

68 “Jsme národem mírumilovným,” Humoristické listy (16 December 1927), 709. Photograph by the author. 
A memorable representation of Czech fears of territorial loss appeared in a political cartoon published in Humoristické listy in December 1927 (See figure 8.1). The cartoon depicts a Czech government minister giving a speech while referring to a wall map of the Czechoslovak Republic. The minister expresses pride that Czechoslovakia is "a peace-loving nation, a democratic nation" and ready to negotiate border alterations with its neighbours Germany, Poland, Hungary, Austria and Romania. As he refers to each country, territories on the map of Czechoslovakia behind him disappear one by one until the only territory left is Prague. The Sudetenland, Ruthenia, Slovakia and eventually the entire country vanish from under his nose. The professor then turns in surprise and shouts "Good God, where is the Czechoslovak Republic?" while the audience laughs at his naievety. ${ }^{69}$ By the late 1920 s many Czechs clearly felt they were surrounded by enemies who were merely waiting for the right time to assert their claims on Czechoslovakia's territory.

\section{Defending Ruthenia "To the Last Drop of Blood"}

Czechoslovakia's enemies grew stronger in the 1930s, and international hostility to Czech rule in Ruthenia forced Foreign Affairs minister Beneš to take decisive action. In an impassioned 1934 speech in Uzhhorod he defended the republic's territorial integrity in the face of irredentism. He declared that Czechoslovakia would never surrender Ruthenia:

This part of the republic is ours and will remain ours. This is a conviction for which everyone from Prague to Uzhhorod stands firmly and steadfastly, and if anyone wanted to make a claim on this territory, it would mean this: a fight to the last drop of blood. [...] This is a question of state and national pride and honour for Czechoslovakia. ${ }^{70}$

He rejected accusations by foreign agitators that Czechs had imperialist aims, claiming that "the joining of Subcarpathia to our republic was not an act of imperialism, nor was it an expansionist aim of Czechoslovakia." ${ }^{71}$ Beneš had already stressed the essential geostrategic significance of Ruthenia in a speech in Nové Zámky in Slovakia a year earlier: "I affirm and I repeat, we shall

\footnotetext{
69 “Jsme národem mírumilovným,” Humoristické listy (16 December 1927), 709.

${ }^{70}$ Speech by Edvard Beneš printed in "Problém karpatoruský a jeho vztah k republice Československé," Moravská orlice (4 May 1934), 1.

${ }^{71}$ Speech by Edvard Beneš printed in “Problém karpatoruský a jeho vztah k republice Československé," Moravská orlice (4 May 1934), 1.
} 
never abandon Ruthenia, for it is precisely on Slovakia and Ruthenia that we build up our policy of the Little Entente [...] We shall therefore never allow our territorial link with Romania to be

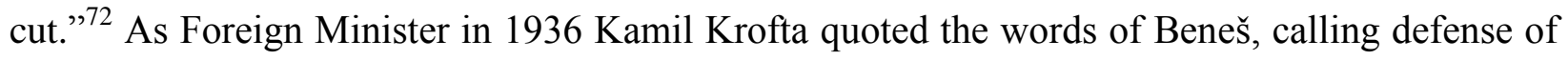
Ruthenia "a question of state and national pride and honour.",73

To counter foreign claims of imperialism and mistreatment, the Prague government began a campaign to actively promote the successes of Czech officials in Ruthenia for a domestic and international audience. Foreign Minister Krofta produced books and articles which highlighted the historical links between Rusyns and Czechoslovaks as fellow Slavs and rejected foreign claims to the territory. ${ }^{74}$ The Czech mayor of Uzhhorod, Dr. Alois Raušer, praised the work of Czech officials and hoped to increase awareness of their efforts: "None of us understand the importance of what they have done there. [...] Czechs have been teachers for the local population in all types of work." 75 In 1933 the ruling Agrarian Party produced a Hungarianlanguage pamphlet which celebrated ten years of Antonín Rozsypal's rule as Czech vicegovernor. The pamphlet called Rozsypal "the most humble man in all the land" and recounted how he would "travel to Prague in a third-class carriage even if he had a first class ticket." The pamphlet asserted that Rozsypal's anniversary in Ruthenia "was celebrated by all inhabitants, regardless of nationality."76

Czech officials in Ruthenia published a number of books intended to respond to the accusations of imperialism made against them abroad. The authors of these books usually declared this intention in the introduction; a 1933 book by officials in Uzhhorod included the following mission statement:

When an anti-Czech campaign began in some foreign publications, the purpose of which was to criticize the Czechoslovak government on the international stage for allegedly causing the poverty of the Rusyn people, it was clear to us that a publication was needed $[\ldots]$ not only to answer our foreign enemies, $[\ldots]$

\footnotetext{
72 Edvard Beneš, speech reprinted in Le Monde Slave (February 1934), 55.

${ }^{73}$ Krofta, "Čechoslováci a Podkarpatská Rus," 28.

${ }^{74}$ Kamil Krofta, Podkarpatská Rus a Československo (Prague: Svaz národního osvobození , 1934); Kamil Krofta, The Substance of Hungarian Revisionism (Prague: Orbis, 1934); Kamil Krofta, La Tchécoslovaquie en face de la tension internationale (Prague: Orbis, 1937).

75 “Podkarpatská Rus vykazuje ohromný pokrok," Moravská orlice (7 January 1934), 3.

${ }^{76}$ L. Balkányi, Tiz év Podkarp. Ruszban (Uzhhorod: self-published, 1933), 1-5.
} 
but to show that under the patronage of the Czechoslovak government Subcarpathian Ruthenia has taken steps forward. ${ }^{77}$

Publikace pro Podkarpatská Rus [A Publication for Ruthenia] collected the writings of several Czech officials as a response to "very one-sided" foreign coverage of Ruthenia, with the intention of "showing the public what Czechoslovakia has invested in Subcarpathian Ruthenia and improvements which have been made at the cultural level and in the economy."78 Published in Czech with an English-language summary, the book included comprehensive statistics to prove the point that life had improved for Rusyns under the rule of Czech officials.

Beginning in 1934 a series of diplomatic alliances divided Central Europe, raising the stakes in the struggle for control of Ruthenia. A treaty of understanding between Poland and Germany weakened Czechoslovakia's geostrategic position in relation to the irredentist aims of these states and Hungary. In response, Foreign Minister Beneš sought an alliance with powerful states, looking particularly to France and the Soviet Union for protection. The signing of the Czechoslovak-Soviet Treaty of Alliance in May 1935 offered a measure of security, as the arrangement meant a de facto agreement with France. ${ }^{79}$ The new alliance led Hungary and Poland to stregthen their ties to counter the development. Hungarian mouthpiece Danubian Review called Czechoslovakia's agreement with the Soviets evidence of why Ruthenia had been "denied even the most elementary rights of self-determination" as part of the Prague government's plan to create a "North-Eastern Slav corridor to establish direct communication with Moscow." Danubian Review also reflected on the dangers of Russian expansion into Central Europe, concluding that "the realization of Ruthenian autonomy" could save the Rusyns from Bolshevization while offering "a line of communication between two friendly powers Poland and Hungary - an issue which would also provide an impregnable bulwark to resist all Russian endeavours at expansion. ${ }^{\prime 80}$ This image of Hungary and Poland as a line of defense protecting Europe from eastern invaders had a long historic lineage to draw upon.

\footnotetext{
77 Jaromír Musil, ed., Technická práce v zemi Podkarpatoruské 1919-1933 (Uzhhorod: Státní tiskárny, 1933$), 3$.

${ }^{78}$ Gustav Bianchi, ed., Publikace pro zem Podk. Rus (Banská Bystrica: Slovan, 1932), 3.

${ }^{79}$ Igor Lukes, Czechoslovakia between Stalin and Hitler: The Diplomacy of Edvard Beneš in the 1930s (New York: Oxford University Press, 1996), 46.

${ }^{80}$ Joseph Illes-Illyasevics, "The Autonomy of Ruthenia and the Czecho-Slovak Minority Questions," in Danubian Review (July 1938, vol. 6, no. 2), 16-17.
} 
In 1938 the mortar holding Czechoslovakia together began to weaken as the political environment of Central Europe turned against the Prague government. Germany made claims for the Sudetenland, and other rivals eager to claim parts of Czechoslovakia's territory began to smell blood. As revision of the Treaty of Trianon became a real possibility for Hungary, Danubian Review lamented the "enormous historical blunder" made by the Czechs when they "occupied pure Magyar territories" which they would "never be able to keep." Responding to hopes in Paris' Le Temps of a French alliance involving Czechs and Hungarians, the author claimed that it was "impossible" to speak of an alliance with the Czechs until "the territorial demands which we have formulated against Czecho-Slovakia” had been satisfied. ${ }^{81}$

\section{Instability in Carpatho-Ukraine and Hungary's Triumph}

Following the Munich Agreement and the granting of Rusyn autonomy in October 1938, the Magyarone Rusyns openly called for reunification with Hungary. Censorship of the Rusyn press was lifted and publications such as Andrei Brodii's organ Russkii vîstnyk had free reign to express anti-Czechoslovak opinions and call for independence. Brodii and Stefan Fentsik wished to hold a plebiscite on returning the territory of Ruthenia to Hungary, and Brodii advocated a return to Magyar rule: "Rusyns want to be with their brothers, to go into the friendly embrace of Hungary." 82 Russkii vîstnyk also published a front-page declaration by Hungarian Regent Miklós Horthy which encouraged Rusyns to return to the Hungarian fold: "The light of the Holy Crown will shine above you once more, again you will live in a united power. Paternal Hungarian love and care will greet you." 83 The agitation for a plebiscite on returning to Hungary rang alarm bells in Prague, confirming the Prague government's fears that granting Rusyn autonomy posed serious risks for what remained of the Czechoslovak state.

After Czechoslovak police found evidence of Magyar irredentist plans in Brodii's home in October 1938, he was arrested and charged with treason against the republic. ${ }^{84}$ The arrest prompted Danubian Review to remark that he had been sent to prison "merely for demanding a

\footnotetext{
${ }^{81}$ Francis Herczeg, “Triple Alliance?” in Danubian Review (February 1938, vol. 5, no. 9), 3.

82 "Nemozhlyvoe polozhenie Podkarp. Rusy iz ohliadu relyhiinoho, natsional'noho y hospodarskoho," Russkii vîstnyk (11 December 1938), 1.

83 “Rusynŷ!” Russkii vîstnyk (20 November 1938), 1.

84 “Andrey Brody zatčen,” Našinec (1 November 1938), 2.
} 
plebiscite in Ruthenia," while calling the autonomy of Slovakia and Ruthenia "nothing but an unscrupulous farce." ${ }^{\prime 85}$ Remarking on the fate of Brodii, British journalist Michael Winch claimed that "after this unfortunate experience the Czechs felt that their previous doubts about granting autonomy had been justified, and every development in the province became an occasion for suspicion." ${ }^{\text {86 }}$ The Prague government quickly selected Ukrainophile Rusyn Avhustyn Voloshyn to replace Brodii as Premier of the Ruthenian parliament.

Hungary and Poland continued to lobby for territorial revision following the achievement of Rusyn autonomy. Demonstrations in support of gaining a common border occurred in Warsaw, Budapest and other major cities in Poland and Hungary in October $1938{ }^{87}$ Danubian Review remarked that there was "no member of the Hungarian nation who would not be willing to lay down his life, if by that means Hungary's and Poland's common aim could be realized." The first stage of these revisionist goals was finally achieved on 2 November 1938 when the First Vienna Award granted Hungary the southern regions of Ruthenia and Slovakia. The award, established by the outcome of the Munich Agreement, included the two largest Ruthenian cities Uzhhorod and Mukacheve, which forced the Rusyn autonomous government of Voloshyn to move to the smaller city of Khust. The diminished territory of Ruthenia was renamed CarpathoUkraine [Karpats'ka Ukraina] by the Ukrainophile-dominated Rusyn parliament. ${ }^{89}$

Following the declaration of autonomous Carpatho-Ukraine, both Germany and Italy established diplomatic influence in the territory. Voloshyn negotiated with Berlin as rumours swirled that Hitler planned to use Ruthenia as the first piece of a larger Ukrainian republic under German hegemony. ${ }^{90}$ The new capital of Khust soon hosted a German consulate and a group of German diplomats intent on developing relations with Voloshyn's government and offering their support to the small German minority in the territory. ${ }^{91}$ Italy's willingness to back a common Hungarian-Polish frontier merely added to the darkening mood expressed in the Czech media in the final weeks of 1938. The Olomouc newspaper Našinec reported that an Italian journalist had

\footnotetext{
${ }^{85}$ Nicholas Udvardy, "Poland's Efforts to Obtain a Common Frontier with Hungary," Danubian Review (OctoberNovember 1938, vol. 6, no. 5-6), 17-19.

${ }^{86}$ Michael Winch, Republic for a Day: An Eye-Witness Account of the Carpatho-Ukraine Incident (London: Robert Hale, 1939), 30.

${ }^{87}$ Udvardy, "Poland's Efforts to Obtain a Common Frontier with Hungary," 17-19.

${ }^{88}$ Udvardy, "Poland's Efforts to Obtain a Common Frontier with Hungary," 17-19.

89 "Parlament jedná o autonomii Slovenska a Podkarpatské Rusi," Národní listy (19 November 1938), 1.

${ }^{90}$ Stercho, Diplomacy of Double Morality: Europe's Crossroads in Carpatho-Ukraine, 328-329.

${ }^{91}$ Winch, Republic for a Day, 21.
} 
arrived in the capital Khust, and that the media of Italy, Poland and Hungary were spreading false rumous of chaotic conditions in Ruthenia:

The clear tendency of the Hungarian media, which has been adopted by the Polish and Italian press offices, is directed towards creating the impression in those countries that Subcarpathian Ruthenia is a source of unrest and fighting. These reports, which in recent days have been steadily growing, are completely untrue. In all of Ruthenia it is peaceful in the villages and towns. Only in the border regions are terrorist gangs from Hungary and from Poland still found who are threatening the border villages. ${ }^{92}$

On 27 October Našinec declared "Subcarpathian Ruthenia will not be intimidated by terrorists" and blamed the Hungarian minority for actively collaborating with the Hungarian government. ${ }^{93}$ In December Hungarian activists were sentenced to prison after offering money to villagers in settlements near Uzhhorod in return for signatures on a petition to rejoin Hungary. ${ }^{94}$ The Czechoslovak government still exerted nominal control over Ruthenia by the end of 1938, but it was slowly losing its grip.

Yet another national group presented a challenge to the Prague government's hold on Ruthenia after the declaration of Rusyn autonomy. The Organization of Ukrainian Nationalists (OUN) [Orhanizatsiia ukraïns'kikh natsionalistiv], representing Ukrainians in neighbouring Polish Galicia, looked upon Carpatho-Ukraine as a Ukrainian territory which had successfully achieved political autonomy, and OUN activists arrived in Khust ready to help defend the region as the first piece of an independent Ukrainian state. ${ }^{95}$ Led by Dmytro Klempush, the Ukrainian Galicians formed a military organization called the Ukrainian Sich and began arming themselves and recruiting Ukrainophile Rusyns for their cause. ${ }^{96}$ The Sich looked upon Czechs much as they had looked upon Poles, as unwelcome oppressors of Ukrainian sovereignty. British reporter Michael Winch described a scene he witnessed at that time in Khust where a Czech official wearing a Czechoslovak flag lapel tried to enter a government building and was physically attacked by Sich guards: "You are in Carpatho Ukraine here,' they said. 'I know,' the Czech replied, but it is a part of the Czechoslovak Republic. [...] 'But this is our land' they started

\footnotetext{
92 “Terroristická tlupa zneklidňuje Podkarpatskou Rus,” Našinec (20 November 1938), 3.

93 "Podkarpatská Rus se nedá zastrašít teroristy," Našinec (27 October 1938), 1.

94 "Peníze za podpisy," Lidové noviny (14 December 1938), 1.

${ }^{95}$ Winch, Republic for a Day, 16.

${ }^{96}$ Magocsi, The Shaping of a National Identity, 241.
} 
shouting again, 'here we rule.' [...] Eventually the Czech left. We wondered what happened to him in the evening when no one was about." $" 97$

The Prague government imposed a shakeup on the government of Carpatho-Ukraine in January 1939 in a last-ditch attempt to reassert its control over the territory. President Emil Hácha gave Lev Prchala, a Czech army general, a ministerial post in the Carpatho-Ukraine government. ${ }^{98}$ Prchala's first move after being sworn in was to request that Voloshyn immediately disband the Carpathian Sich militia which he saw as a Galician-led threat to Czechoslovak sovereignty. ${ }^{99}$ Voloshyn refused the request and protests organized by Galician Ukrainians erupted in Khust at this attempt by the Prague government to keep a leash on the autonomous Carpatho-Ukrainian government. ${ }^{100}$ A further conflict between Khust and Prague involved the many Czechoslovak officials in the territory; following the creation of the autonomous government Voloshyn did not continue to employ most of the officials and their return from Ruthenia to the Bohemian lands became the responsibility of the Prague government. ${ }^{101}$ Brodii's organ Russkii vîstnyk praised the changes taking place in the administration, with Rusyns replacing Czechs in high positions: "Finally our people can lead in Subcarpathian Ruthenia! They should lead since they know the needs of our families and the right path for the future of our nation." 102

A rapid series of events spelled the end of the Rusyn autonomous government and of Czechoslovakia on 14-15 March 1939. The Ukrainian Sich's distrust of General Prchala and the continued interference of the Prague government in the territory's affairs led to a battle between the Sich and Prchala's Czechoslovak troops in the streets of the capital Khust. ${ }^{103}$ With Adolf Hitler's approval, Jozef Tiso declared Slovakia to be an independent republic on 14 March. The German army marched into the Bohemian lands and occupied Prague the following day. Hungarian troops began massing near the frontier with Ruthenia. Voloshyn quickly declared the independence of Carpatho-Ukraine on 15 March, but in less than 24 hours the territory had been overrun by the Hungarian army. Voloshyn fled across the border to safety in Romania; in

\footnotetext{
${ }^{97}$ Winch, Republic for a Day, 22.

98 “Čech ve vládě Karpatské Ukrajiny," Karpato-Ukrajinská svoboda (20 January 1939), 7.

${ }^{99}$ Stercho, Diplomacy of Double Morality: Europe's Crossroads in Carpatho-Ukraine, 132.

100 "Riot in Ruthenia," London Times (18 January 1939), 11.

101 "Poslední zprávy," Karpato-Ukrajinská svoboda (13 January 1939), 4.

102 "Peremînŷ v Uriadakh," Russkii vîstnyk (23 October 1938), 3.

${ }^{103}$ Winch, Republic for a Day, 225.
} 
Sighetu Marmației he sent a telegram to President Emil Hácha in Prague declaring that "all of our nation is against joining Hungary." 104 The simultaneous collapse of the government in Prague left Czechoslovak troops powerless to fight back against the Hungarians, who quickly overcame resistance from the Ukrainian Sich and on 16 March finally stood in triumph on the border with Poland. ${ }^{105}$

The Prague government's failure to defend Ruthenia against Hungarian irredentism lay partly in its foreign policy decisions, though ultimately the rise of the Axis powers and their support for revision of the Trianon Treaty made the outcome hard to avoid. The League of Nations had generally supported the Czech administration of Ruthenia, but the declining influence of the League and the Allies in the 1930s left Czechoslovakia with limited diplomatic options at its disposal. While the Prague government had viewed Ruthenia as a temporary appendage and a potential burden at the outset of the republic, the region's geostrategic value grew exponentially throughout the interwar period. Given its role as a vital link with fellow Little Entente members Romania and Yugoslavia, Edvard Beneš eventually declared that Czechoslovakia would never surrender Ruthenia to Hungarian and Polish irredentist interests. Autonomy for Rusyns could not be granted due to the revisionist risks such a move presented, so Czech officials searched for convincing reasons to explain to the League of Nations why autonomy could not be granted as stipulated in the Treaty of Saint Germain. Czech officials claimed in their defense that they were educating the Rusyn nation so that one day they could rule themselves, an assertion which reflects Osterhammel's view of compassionate colonialism as justification for a process of "pedagogical influence."106

Faced with accusations of neglecting the rights and wishes of the Rusyn people, the Czechoslovak government repeatedly denied that its actions in Ruthenia could be labelled as imperialist. These denials rested on Slavic kinship and the improving living standards of the region's inhabitants, while Prague claimed that the previous Hungarian government was the one truly worthy of the imperialist label. The Czechoslovak government's campaign to highlight the benevolent and beneficial nature of its Ruthenian administration also mirrored the practices of

\footnotetext{
${ }^{104}$ Avhustyn Voloshyn, Telegram sent to Emil Hácha, 15 March 1939. AKPR Fond PR, carton 15, document PR 93/39.

105 “Capitulation by Ruthenia,” London Times (16 March 1939), 15.

${ }^{106}$ Osterhammel, Colonialism: A Theoretical Overview, 35.
} 
West European powers such as France who were eager to promote the virtues of their colonial practices as a mission civilisatrice. The Interior Ministry's comparison of the status of Ruthenia in Czechoslovakia to that of the Philippines under US rule suggested the government considered the territory to have the legal status of a colony, an imperial possession with inhabitants who needed leadership and training to prepare them for autonomy. Although Czechoslovakia would return following the end of World War Two, the Prague government would never regain Ruthenia, a loss of an imperial possession which still inspires Czech nostalgia today. 


\section{Conclusion}

The theme of this study has been a reassessment of the relationship between Czechs and Rusyns in Czechoslovakia through the lens of colonialism and imperialism. It contributes to a growing field of colonial case studies located geographically within continental Europe. A further intention has been to shed new light on the day-to-day activities and concerns of Czechoslovakia's administration of Ruthenia while attempting to debunk commonly-held assumptions about Slavic unity and Rusyn appreciation of Czech rule. In contrast to most colonial scholarship, this study has provided perspectives from both the colonizer and the colonized, giving Czech and Rusyn voices equal prominence.

Assessing Czech involvement in Ruthenia as a colonial encounter has contributed to debate surrounding the legitimacy of colonial studies in European territories. Frederick Cooper has opposed such broad colonial classification, though as Larry Wolff and Kristin Kopp have shown, demarcation lines on the continent of Eurasia separating European civilization from the Oriental "Other" have never been clearly defined, leaving a spectrum of various grades or levels of Orientalism in the eyes of European observers. ${ }^{1}$ Czechs cast themselves as members of Western Europe who could look down on the primitive lands of Ruthenia; Milica BakićHayden's term Nesting Orientalisms further reflects this concept within Czechoslovakia, with a hierarchy of Czechs, Slovaks and Rusyns from west to east. ${ }^{2}$

Czech interwar authors and journalists often spoke of Ruthenia as "half-Oriental," marking it as part of a transitionary grey area between Europe and Asia. Larry Wolff has called the characterization of Eastern Europe as a land between civilization and barbarism "as old as the enlightenment," 3 while Maria Todorova considers the Balkans to be a similar transition zone in western thought. However, in contrast to Wolff and Todorova's assessment of west European views of the East European Other, the hypothetical Ruthenianism of this study occurred between nations with a common ethnic background and within the borders of a single state. Despite Slavic kinship and the Czech nation's previous experience as a subordinate nation within Austro-

\footnotetext{
${ }^{1}$ Kopp, Germany's Wild East, 202; Wolff, Inventing Eastern Europe, 6-10.

${ }^{2}$ Bakić-Hayden, "Nesting Orientalisms: The Case of Former Yugoslavia," 917-931.

${ }^{3}$ Wolff, The Idea of Galicia: History and Fantasy in Habsburg Political Culture, 243.
} 
Hungary, Rusyns became an uncivilized people in need of colonizing in the eyes of Czech observers.

In assessing the colonial dimensions of Czech involvement in Ruthenia this study has considered the discursive aspect of the relationship separately from the materialist aspect. For the purposes of this analysis, material colonialism has referred to the institutions and political structures used by a foreign minority to subjugate a native population. Discursive colonialism refers to the development of a colonial framework in the imaginations of both the colonizers and colonized. Approaching these components as two distinct elements of a colonial relationship has permitted greater attention to be paid to the significance of a discourse in Czech-Rusyn relations; Kristin Kopp sees it as a crucial aspect, as "material colonization does not occur as such where the discursive groundwork has not been laid."

In newly-independent Czechoslovakia a colonial discourse developed through deployment of colonial terminology by the Czech and Rusyn media, scholars and political elites. The use of colonial stereotypes became a widespread phenomenon in Czech newspapers, magazines, novels and travel guides, with the daily press playing an important role in creating a colonial perception of Rusyns and Ruthenia among the public in the early years of the Czechoslovak state. Describing Rusyns as primitive, childish, lazy, passive, simpleminded, unclean, feminine, drunken and unable to learn and reason for themselves cast them as an unCzech "Other" who required Czech education and administrative order. These stereotypes affirmed Czech resolve for conducting what became a mission civilisatrice for Rusyns. Frequent references to Ruthenia as an African or Oriental colony placed Czechs and Rusyns into a relationship between colonizer and colonized which reflected perceptions of a civilizational divide between the two nations. The stereotypical cartoons and colonial language of František Svojše encouraged Czech officials in Ruthenia to view Rusyns as an inferior people who needed Czech colonial leadership for their own betterment. As Jürgen Osterhammel and Chris Bayly have suggested, a discursive relationship also requires acknowledgement by the colonized, and the Rusyn elite reacted to the label of "Czechoslovak colony" by using the term to criticize their Czech administrators. Rusyn elites compared their plight to slaves in India under British rule, and to the mistreatment of natives in colonial Africa.

\footnotetext{
${ }^{4}$ Kopp, Germany's Wild East, 6.
} 
The case presented for material colonialism by the Czech administration is harder to compare directly to non-European examples of colonialism. The Czech administration did not openly seek to exploit Ruthenia for material gain and the government invested far more in the territory than it ever received from it in taxation or natural resources. Beginning in 1923 Rusyns could vote and run for public office and some achieved election to the national parliament as MPs. Although Ruthenia's regional administration remained dominated by Czechs until 1938, some Rusyn intellectuals and other minorities including Hungarians and Germans found positions in the lower and middle levels of the bureaucracy and were well-represented in government jobs such as hospital workers and notaries, particularly in the 1930s. ${ }^{5}$ The years of Czechoslovak administration also brought tangible benefits to Ruthenia; new infrastructure such as railways, roads and bridges opened remote villages to the outside world and modernization. The work of the Czechoslovak Red Cross and new hospitals eradicated common diseases which had plagued the region, and food distribution and agricultural programs reduced formerly widespread hunger.

However, some aspects of the Czech administration more readily support the label of material colonialism. Rusyns never reached positions of real power in the government hierarchy, despite their legal right to political autonomy enshrined in the Czechoslovak constitution. Most Czech officials in Uzhhorod inhabited a self-contained social and public sphere separated from the Rusyn elite and had little interaction with them beyond administrative matters. Czech businesses quickly established themselves in Uzhhorod and Ruthenia's larger cities and forced many local businesses to close due to their competitive advantage. Czech companies profited from harvesting Ruthenia's forests and salt flats while local Rusyns who tried to cut trees or obtain salt for personal consumption faced prosecution by government-appointed gendarmes. Although regulations required Czech gendarmes to treat Rusyn peasants as equal citizens, many examples of mistreatment suggest a hierarchy based on ethnicity. The establishment of Czech schools and the arrival of legionaries as farming settlers drew charges of Czechization from the Rusyn elite, and unpublished government reports suggest that at least some administrators harboured hopes for their eventual assimilation. Officially the Czech administration considered

\footnotetext{
${ }^{5}$ Statistics from the Zemski Urad in Uzhhorod cited in: Macartney, Hungary and Her Successors, 225.
} 
improving conditions for Rusyns to be their primary goal for the territory, though in practice gendarmes and local officials sometimes misused their authority for profit.

As other scholars applying colonialism to case studies within Europe have found, discursive colonialism has proven easier to identify in Ruthenia than material colonialism. In assessing the applicability of colonialism to Galicia in interwar Poland, Christoph Mick found that Poles cast the eastern borderlands as uncivilized territories in need of Polish guidance. He made a compelling case for discursive colonialism which existed "in the Polish imagination," since Polish elites considered Ukrainians to be "children incapable of ruling themselves," 6 but he could not ascribe a material colonialist intent to the Polish administration comparable to examples of overseas colonialism. Kristin Kopp has declared that European case studies of colonialism may not necessarily involve forms of material colonization seen overseas. ${ }^{7}$ Róisín Healy and Enrico Dal Lago have also stated that discursive colonialism did not usually develop into institutional forms of material colonization in most European instances. ${ }^{8}$ While the case of Ruthenia bears a close resemblance to examples of discursive colonialism in Europe presented by Kopp and others, comparing Czech rule directly to the institutions of overseas colonial administrations is less defensible.

In considering the question of colonialism this study has also provided a fresh analysis of Czechoslovak government policies and the activities of Czech officials in interwar Ruthenia. The story of the establishment of a Czechoslovak administration in Ruthenia has been told through the words of the officials themselves, depicting their fears and opinions of Rusyns and the new land in which they lived. This study has also uncovered the extent of corruption which existed among Czech officials in Ruthenia; complaints by the Rusyn elite and the reaction of government officials such as Jaromír Nečas suggest the problem of corruption became widespread in the early 1920s, with officials seeking to profit from their positions as gendarmes, notaries and border guards in regions without direct administrative supervision. Corruption in the administration and its negative impact on Czech-Rusyn relations is an issue which has yet to be significantly considered in academic scholarship in any language.

\footnotetext{
${ }^{6}$ Mick, "Colonialism in the Polish Eastern Borderlands 1919-1939," 138.

${ }^{7}$ Kopp, Germany's Wild East, 6.

${ }^{8}$ Healy and Dal Lago, Introduction to The Shadow of Colonialism on Europe's Recent Past, 9.
} 
This study also sheds new light on the friction of Czech-Rusyn relations in Ruthenia by identifying František Svojše as a potent symbol of Czech chauvinism and imperialism. Scholarship has yet to appreciate Svojše's significant impact in souring Czech-Rusyn relations in the second half of the 1920s. His media campaign, beginning in January 1925 with the publication of Podkarpatské hlasy, promoted the benefits of Czechization and belittled Rusyns for an audience of Czech officials in the territory. The Rusyn media condemned his anti-Rusyn outbursts repeatedly throughout 1925 and 1926. The impetus for the Uzhhorod protests in February 1927 calling for Rusyn autonomy and an end to Czechization also lay at least partly at Svojše's feet. His subsequent downfall and arrest in a pedophile scandal which shocked Ruthenia in 1928 brought further condemnation from Rusyns who saw him as a representation of all the evils of the Czech administration. Even Prague-loyalist Ukrainophiles such as Voloshyn bewailed Svojše's influence in turning Czech officials from benefactors into "dictators."

Ivan Olbracht and the anti-imperialist Czech Communists also accused Czech officials of transforming from Slavic helpers into autocratic rulers. The anti-Czech writings of Olbracht, Stanislav Kostka Neumann, Vašek Káňa and others in the movement have so far been largely overlooked in scholarship, dismissed as Communist mouthpieces whose opinions remain tainted by ideology. The accusations made by Olbracht and the Communists are comparable to contemporary anti-imperialist movements then occurring among European colonial powers; Stephen Howe's analysis of the British anti-imperialist movement among the political left-wing suggests similarities in the defense of equal rights for all citizens. ${ }^{10}$

In contrast to previous Anglophone and Czech-language scholarship on interwar Ruthenia this study has looked at both Czech and Rusyn viewpoints and sources in equal measure. Emphasis on including regional and non-elite Rusyn voices has provided insight into how Rusyn peasants perceived their conditions in Czechoslovakia. Gendarme reports, government inspection reports and foreign travellers' accounts of visits to the Rusyn highlands have provided some insight into the thoughts of the Rusyn peasantry, while letters to newspaper editors offer opinions from the intelligentsia outside Uzhhorod and the main cities. Rusyn

\footnotetext{
${ }^{9}$ Avhustyn Voloshyn, Letter to President T. G. Masaryk, 19 March 1928. AÚ TGM Fond TGM-R, carton 403, document no. 2258/28.

${ }^{10}$ Stephen Howe, Anti-colonialism in British Politics: The Left and the End of Empire, 1918-1964 (London: Clarendon Press, 1993).
} 
villagers appear to have considered Czech officials to be less menacing than their former Hungarian masters, though this perhaps meant they also afforded them less respect. Rusyn intelligentsia living in rural regions provided most of the descriptions of corruption by Czech officials and mistreatment of the peasants.

Although most current academic scholarship depicts the years of Czechoslovak rule as generally beneficial for Ruthenia, beneath the surface the relationship between Czechs and Rusyns lay fractured by distrust and anger. Elaine Rusinko's claim that the period formed a "true renaissance" 11 for Rusyns may be appropriate in terms of cultural development, but it masks a deep animosity between the Rusyn elite and their Czech administrators which led to frequent protests and political confrontation. Close examination suggests Czech officials often behaved like foreign rulers, even if they portrayed their activities as kindness for a fellow Slavic nation.

The memory of Ruthenia has continued to haunt Czech minds since the loss of the territory in 1939. Following the collapse of communism in Czechoslovakia in 1989, a resurgence of interest in rebuilding links between the Bohemian lands and Ruthenia occurred. New books and academic scholarship appeared in the 1990s, and Czech organizations reached out to establish contact with Rusyns in fields including culture, tourism and investment. Regional Czech chambers of commerce and academic institutions established links with their counterparts in Ruthenia and sought to play a mentoring and advising role. For a brief moment the possibility of rejoining Ruthenia to the republic appeared; the right-wing Republican Party of Czechoslovakia [Republikánska strana Československa] called for reunification with Ruthenia, and party leader Miroslav Sládek actually travelled to Ruthenia and unfurled a Czechoslovak flag. ${ }^{12}$ However, the Velvet Divorce which divided Czechoslovakia into the Czech Republic and Slovakia on 1 January 1993 brought an abrupt end to such hopes.

Ruthenia's inclusion within the borders of Czechoslovakia lasted just twenty years, but both Czechs and Rusyns have mythologized this period in their histories. Czech poet Miroslav Holub described his nation's nostalgia for the lost region in 1999: "Subcarpathian Ruthenia is something like a pearl resting at the bottom of the ocean, something barely found before again

\footnotetext{
${ }^{11}$ Elaine Rusinko, Straddling Borders: Literature and Identity in Subcarpathian Rus' (Toronto: University of Toronto, 2003), 296.

${ }^{12}$ Paul Robert Magocsi, “The Heritage of Autonomy in Carpathian Rus' and Ukraine's Transcarpathian Region," Nationalities Papers (2015, vol. 43 no. 4), 586.
} 
being lost, a sixth finger amputated before we had learnt to use it. And we are still feeling the phantom pain."13 In turn, Rusyns now look west across the border of the European Union to the Czech Republic as a popular destination for employment and immigration; the abundance of Czech vehicle registration plates on the roads in Ruthenia reflects the large number of Rusyns who have taken up residence there.

Imperial nostalgia tourism also attracts busloads of Czech tourists to Ruthenia each summer, eager to experience a region which once lay within their borders. They come to see the physical traces of Czechoslovak administration which are still visible in Ruthenia: the Galago quarter with homes and offices constructed for Czechoslovak officials which still stands in Uzhhorod, and the bust of President Masaryk which stands in a square. Locals have tried to capitalize on Czech interest in their cities and towns by displaying Czechoslovak-era street signs and restoring historic Czech-language signs on buildings. Czech nostalgia tourism is most apparent in towns such as Kolochava, where museums and monuments to Ivan Olbracht's time in residence draw Czechs eager to step into the fantasy world of Nikola Šuhaj. Those who come can stay and eat in the aptly-named guest house Četnická stanice [Gendarme station], decorated with memorabilia from the Czechoslovak era. ${ }^{14}$

A highly symbolic reminder of Ruthenia's inclusion in Czechoslovakia lies hidden among the trees on Petrín hill in the centre of Prague, not far from the historic streets of Malá Strana and the bustling district of Anděl. The colourfully painted onion domes of the wooden church of Saint Michael point to its origins in the remote Rusyn village of Medvedivtsi/Medvedovce near Mukacheve. Transported by train to the Czechoslovak capital in 1929, the church functioned as a cultural curiosity to show Prague citizens the unique customs and architecture of Rusyns. An unveiling ceremony in September 1929 included folk dance performances by the Rusyn villagers who had formerly used it as their place of worship. Prague newspapers spoke of the church as a new symbol of Slavic friendship in the republic, ${ }^{15}$ yet it also represented Czech interest in the exotic otherness of the Rusyns and their distant territory. Bringing such a recognizable symbol of Rusyn culture to Prague for display as a curiosity

\footnotetext{
${ }^{13}$ Miroslav Holub, introduction to The Sorrowful Eyes of Hannah Karajich, by Ivan Olbracht (Budapest: Central European University Press, 1999), vii.

${ }^{14}$ During a visit to Kolochava in 2013 the author noted that much of the town's economy is tied to Czech tourist visitors, with Czech-language signage offering accommodation in many homes.

15 “Podkarpatský kostelík již stojí v Praze," Jas (29 August 1929), 2-3.
} 
reflected the perceived civilizational superiority of Czechs in a relationship which was never equal. Five other Rusyn churches moved to the Bohemian lands in the 1920s and 1930s still stand in cities and towns of the modern Czech Republic as reminders of the former imperialist relationship with Ruthenia. 


\section{Bibliography}

\section{Primary Sources}

\section{AÚ TGM - Archiv Ústavu T.G. Masaryka [T.G. Masaryk Institute Archives] TGM-R - Fond T.G. Masaryk - Republika, Podkarpatská Rus}

Albert, Dr. B. "Uvaha o sociálně-zdravotních poměrech v Podkarpatské Rusi se zřetelem na hospodářské, politické a národností otázky." Government report, November 1924. Carton 403.

American National Council of Uhro-Rusins. To His Excellency, Woodrow Wilson, President of the United States of America. October 1918. In Přispěvek kústavním dějinám Podkarpatské Rusi: Memorandum Amerických Rusinů, Zdeněk Peška, ed. Carton 403, document no. 1255/31.

Azcárate, Dr. Pablo. Letter to the Czech delegation for the League of Nations, 10 March 1928. Carton 403.

Czechoslovak delegation to the League of Nations, report draft from November 1928. Carton 403.

Czechoslovak delegation to the League of Nations, report Podkarpatská Rus, 1928. Carton 403.

Czechoslovak Interior Ministry document Informace pro společnost národi̊ o autonomii pro Podkarpatskou Rus, document no. 39894/1928, 18 June 1928. Carton 403.

Czechoslovak Interior Ministry document 14979, 30 October 1919. Carton 403, document no. D 5069.

Czechoslovak Interior Ministry document (\#4447/1932). Prepared by the Provincial Office of Ruthenia in Uzhhorod, 12 March 1932. Carton 403, document no. 482/32.

Czechoslovak Interior Ministry draft report Podkarpatská Rus. 1929. Carton 403, document number 1046/29.

Czechoslovak Interior Ministry draft report Podkarpatská Rus. 1930. Carton 403.

Ehrenfeld, Petr. Report for the Interior Ministry and Presidential Office, 26 August 1920. Carton 400.

Ehrenfeld, Petr. Report for the Interior Ministry, 17 February, 1922. Carton 401. 
Ehrenfeld, Petr. Personal letter to Přemysl Šámal, head of the Presidential Office of the Republic, 1 March 1922. Carton 401.

Masaryk, T.G. Personal letter to Gregory Zhatkovych, 19 November 1918. Carton 400.

Mecher, D. "Politické poměry v Podkarpatské Rusi." Interior Ministry report, 10 December 1921. Carton 400.

Nečas, Jaromír. Progress Report for President T.G. Masaryk, 18 August 1921. Carton 401.

Nečas, Jaromír. Paralysování činnosti Žatkovičovy v Americe. Report prepared for President T.G. Masaryk, 2 December 1921. Carton 401.

Nečas, Jaromír. Stižnosti proti Čsl. republice na mezinárodním foru. Report for President T.G. Masaryk, 1922. Carton 402.

Nečas, Jaromír. Podkarpatská Rus: Zpráva posl. Ing. J. Nečase. Report prepared for President T.G. Masaryk, 13 April 1928. Carton 403.

Nečas, Jaromír. Učel cesty Prof. De Azcarate. Report prepared for President T.G. Masaryk, 1923. Carton 402.

Nečas, Jaromír. Úřednictvo na Podkarpatské Rusi. Draft Report for the Czechoslovak Interior Ministry, 1927. Carton 401, file Nečas - Referat o Podkarpatské Rusi, part A, section 5.

Novotný, A. Report for the Interior Ministry, 26 April 1921. Carton 401.

Parkanyi, Ivan. Poměry na Podkarpatské Rusi. 12 June 1929. Presidential Office document no. T 737/29. Carton 403.

Uzhhorod Administration report for the Interior Ministry, 6 August 1920. Carton 400.

Uzhhorod Administration report for the Interior Ministry, July 1925. Carton 403.

Voloshyn, Avhustyn. Letter to President T. G. Masaryk, 19 March 1928. Carton 403, document no. $2258 / 28$.

Voloshyn, Avhustyn. Report for President T. G. Masaryk, 6 April 1928. Carton 403.

Županskému úřadu ve Volovoje. Regional administration office report, 9 March 1920. Carton 400. 


\section{AKPR - Archiv Kanceláře prezidenta republiky [Czech Presidential Office Archives] PR - Fond Podkarpatská Rus}

Beskid, Antonii. Declaration signed on behalf of the Central Rusyn National Council, 26 June 1920. Carton 2.

Ehrenfeld, Petr. “Článek 'Ruské nivy',” Report for the Presidential Office, 19 March 1921. Document PR 258/21. Carton 3.

Ehrenfeld, Petr. Administrative Document for the Interior Ministry, document no. 9438, 22 May 1922. Carton 4.

Gendarme transcript from a meeting of the Carpatho-Rusyn Labour Party, village of Nižné Nystré, 11 April 1926. Carton 8.

Gendarme transcript from a meeting of the Carpatho-Rusyn Labour Party, village of Kušnice, 18 July 1926. Carton 8.

Gendarme transcript from a meeting of the Carpatho-Rusyn Labour Party, village of Járok, 13 February 1927. Carton 9.

Hora, Alois. Personal letter to President T.G. Masaryk, September 1919. Carton 1, document no. 2809.

Memorandum of the Central Rusyn National Council addressed to T.G. Masaryk and members of the National Parliament. 9 February 1927. Carton 9, document PR 109.

Memorandum a zř́zeni poradního sboru při prezidiu ministerské rady pro Podkarpatskou Rus, 1921. Carton 3, item PR 392, inventory number 234.

Protesty proti akci Rothermerevě. Gendarme report for the Czechoslovak Interior Ministry, 4 September 1927. Carton 9, document PR 365.

Velichovský, František, regional official for the town of Velký Sevljuš. Report for the Civil Administration of Ruthenia and the Interior Ministry about a meeting of the CarpathoRusyn Labour Party in the village of Mali Kopani, 27 May 1927. Carton 9, document PR $280 / 27$.

Voloshyn, Avhustyn. Telegram sent to Emil Hácha, 15 March 1939. Carton 15, document PR 93/39. 


\section{ANM - Archiv Národního muzea [Czech National Museum Archives] Fond Starý and Fond Brandejs (No page numbers given for newspaper clippings)}

28 ř́ijen. “Češi v Podkarpatské Rusi,” 26 March 1924. Fond Starý, Carton 1.

Čas. "Komunisté a Podkarpatská Rus," 9 December 1921. Fond Starý, Carton 1.

České slovo. 14 November 1919. Fond Starý, Carton 1.

České slovo. "Podkarpatská Rus," 20 November 1923. Fond Starý, Carton 1.

Lidové listy. "Nemožné poměry na Podkarpat. Rusi,” 28 February 1928. Fond Starý, Carton 1.

Moravsko-slezský denník. 18 March 1924. Fond Starý, Carton 1.

Moravsko-slezský denník. "Vydavatelstvo 'Podkarpatských Hlasů’ prodáno v kriminále," 3 April 1928. Fond Starý, Carton 1.

Národní listy. "Polský ministr o Podkarpatské Rusi," 8 January 1927. Fond Starý, Carton 1.

Organisaci mad'arských žurnalistů v Československu. Podkarpatská Rus v zrcadle pravdy. Memorandum sent to President T.G. Masaryk, 1925. Fond Brandejs, Carton 1.

Podkarpatské hlasy. "Memorandum: Republikánské strany zemědělského a malorolnického lidu pro vládu republiky Československé," 26 February, 1932: 1. Fond Brandejs, Carton 2.

Růžička, Otokar. Politické proudy v Přikarpatské Rusi. Document of the Czechoslovak Ministry of Post and Telegraph, 12 November 1919. Fond Brandejs, Carton 2.

Slovenská politika. "Nový časopis v Podkarpatskej Rusi," 31 January 1925. Fond Starý, Carton 1.

Tribuna. "Milion liber šterlingů na mad’arisování Podk. Rusi," 27 April 1927. Fond Starý, Carton 1.

Večerník práva lidu. "Středověk v naší republice," 22 March 1920. Fond Starý, Carton 1.

Venkov. "Český úředník na Podkarpatské Rusi," 4 March 1924. Fond Starý, Carton 1.

Venkov. "Madarsko-židovská demonstrace proti republice," 1 March 1921. Fond Starý, Carton 1.

Večerné České slovo. "Vážné nebezpečí polsko-madarských úkladů," 24 November 1920. Fond Starý, Carton 1.

Voloshyn, Avhustyn. “Župní novela a Podkarpatská Rus,” Lidové listy, 16 February 1927. Fond Starý, Carton 1. 


\section{Czechoslovak National Parliament and Senate Speeches and Documents}

Brodii, Andrei. Speech to the Czechoslovak national parliament, 27 April 1933, Session 266.

Brodii, Andrei. Speech to the Czechoslovak national parliament, 17 June 1937, Session 106.

Fentsik, Stefan. Speech to the Czechoslovak national parliament, 25 June 1935, Session 5.

Fentsik, Stefan. Speech to the Czechoslovak national parliament, 17 June 1937, Session 106.

Gagatko, Andrei. Speech to the Czechoslovak national parliament, 1 July 1927, Session 93.

Gáti, József. Speech to the Czechoslovak national parliament, 9 April 1924, Session 259.

Gáti, József. Speech to the Czechoslovak national parliament, 22 March 1928, Session 138.

Gáti, József. Speech to the Czechoslovak national parliament, 13 September 1928, Session 159.

Klofáč, Václav. Speech to the Czechoslovak senate, 5 November 1924, Session 232.

Nečas, Jaromír. Speech to the Czechoslovak national parliament, 9 April 1924, Session 259.

"Proekt deputata d-ra Stepana A. Fentsika konstitutsii avtonomnoi Podkarpatskoi Rusi," Poslanecká sněmovna národného shromáždění republiky československé, IV. 1936. Volební období 3, zasedání 10, VI.

Revai, Iuliian. Speech to the Czechoslovak national parliament, 18 March 1938, Session 142.

Štětka, Josef. Speech to the Czechoslovak national parliament, 22 January 1932, Session 165.

Ústavní listina Československé republiky, 121/1920, 29 February 1920.

\section{Czech and Slovak Newspapers and Magazines with Author}

Brandejs, Jan. "Deset let práce republiky na Podkarpatské Rusi," Podkarpatské hlasy, 28 October 1928: 3 .

Fabinger, Jaroslav. “Městské trhy na Podkarpatské Rusi,” Pestrý tyden, 8 July 1933: 12.

Fastrová, Olga. "My a oni," Národní politika, 29 March 1924: 2.

Fastrová, Olga. "Podkarpatský film," Národní politika. 27 July 1927: 1.

Holeček, Josef. “U Skrejšovského,” Zlatá Praha, 27 October 1920: 391.

Hora, Alois. "Dvě hvězdy," Lidové noviny, 30 September 1921: 11. 
Korčák, Rostislav. "Karpatoruský problém,” Národní listy, 22 May 1919: 1.

Lukavský, František. “O Podkarpatské Rusi,” Český denik, 19 February 1935: 1.

Nečas, Jaromír. “Podkarpatšti Rusíni v naši republice,” Brazda, January 1920: 18.

Olbracht, Ivan. "Země starosti,” České slovo, 17 March 1935: 3.

Rutte, Miroslav. "Bohatýrský román a zbojníku Šuhajovi,” Národní listy, 24 March 1933: 5.

Tomeček, Jaromír. “I na podzim je Podkarpatská Rus krásná,” Pestrý týden, 3 September 1938: 5.

Weyr, František. “Nejnovější Podkarpatská sensace,” Lidové noviny, 19 May 1921: 1.

\section{Czech and Slovak Newspapers and Magazines without Author}

Bratrství. 1923. "Nejbližší úkol slovanské politiky," 8 March 1923: 182.

České slovo. 1919. "Karpatští Rusové v Praze,” 23 May 1919: 5.

České slovo. 1919. “Podkarpatská Rus,” 14 October 1919: 1.

České slovo. 1921. "Z Podkarpatské Rusi: z kraje temnoty,” 30 December 1921: 2.

České slovo. 1924. "Na okraj jubilejních slavností v Podkarpatské Rusi,” 10 October 1924: 3.

Československá republika. 1920. "Problémy Podkarpatské Rusi: Dopis z Užhorodu - 1," 20 August 1920: 1.

Československá republika. 1920. "Problémy Podkarpatské Rusi: Dopis z Užhorodu - 2," 22 August 1920: 1.

Československá republika. 1920. "Dva roky svobody Podkarpatské Rusi,” 7 December 1920: 1.

Československá republika. 1921. "Bosna Československého státu,” 29 December 1921: 4.

Československá republika. 1922. "Ministerský předseda o poměrech v Podkarpatské Rusi a na Slovensku," 4 January 1922: 2.

Československá republika. 1922. “Podkarpatská Rus,” 23 March 1922: 1.

Československá republika. 1923. 19 April 1923: 3.

Československá republika. 1923. "Dílo lásky a zodpovědnosti," 1 March 1923: 5.

Československá republika. 1923. "Z Podkarpatské Rusi: Podkarpatská Rus a Čsl. politika v zrcadle Pařřžského 'Tempsu',” 29 September 1923: 3. 
Český deník 1930. "Podkarpatská Rus," 5 August 1930: 1.

Český deník. 1932. "Podkarpatská Rus,” 19 March 1932: 1.

Český denik. 1934. "Poláci proti naši Podkarpatské Rusi,” 23 December 1934: 2.

Český deník. 1935. “Kritika poměrů na Podkarpatské Rusi,” 24 December 1935: 1.

Český deník. 1936. “Do starého Plzence!” 27 March 1936: 6.

Četnické listy. 1931. "Př́́pad Svojše a četnictvo,” 15 May 1931: 1.

Hlas východu. 1931. "Lid hladoví a páni úřadují," 16 April 1931: 1.

Hlas východu. 1931. "Skutečné otroctví v Indii a na Podk. Rusi," 16 July 1931: 2.

Humoristické listy. 1927. “Jsme národem mírumilovným,” 16 December 1927: 709.

Jas. 1929. "Podkarpatský kostelík již stojí v Praze,” 29 August 1929: 2-3.

Karpato-Ukrajinská svoboda. 1939. "Poslední zprávy,” 13 January 1939: 4.

Karpato-Ukrajinská svoboda. 1939. “Čech ve vládě Karpatské Ukrajiny,” 20 January 1939: 7.

Lidové noviny. 1919. "Po pěti letech," 19 October, 1919: 2.

Lidové noviny. 1920. “Z Podkarpatské Rusi,” 23 March 1920: 3.

Lidové noviny. 1920. “Guvernér Žatkovič o Podkarpatské Rusi,” 15 June 1920: 1.

Lidové noviny. 1921. "Naléhavé otázky Podkarpatské Rusi,” 25 February 1921: 1.

Lidové noviny. 1921. “Autonomie Podkarpatské Rusi,” 13 August 1921: 1.

Lidové noviny. 1921. “Autonomie Podkarpatské Rusi,” 13 August 1921: 1.

Lidové noviny. 1921. "Nebezbečné věci na Podkarpatské Rusi," 6 November 1921: 2.

Lidové noviny. 1921. "Ministerský Předseda Dr. Beneš o politických otázkách," 26 December 1921: 2 .

Lidové noviny. 1922. "Verchovina," 3 December 1922: 4.

Lidové noviny. 1923. "Pumové útoky v Užhorodě," 13 February 1923: 3.

Lidové noviny. 1923. “O židovskou kancelář na Podkarpatské Rusi,” 20 May 1923: 3.

Lidové noviny. 1927. "Protesty z Podkarpatska," 9 February 1927: 2. 
Lidové noviny. 1928. 1 March 1928: 1-2.

Lidové noviny. 1929. "Komunističti spisovatelé proti polbyru a pro mimořádný sjezd," 25 March 1929, morning edition: 1.

Lidové noviny. 1930. "František Svojše žaluje," 5 March 1930: 5.

Lidové noviny. 1932. "Bida na vrchovině," 15 January 1932: 5.

Lidové noviny. 1932. "Konce Františka Svojšeho,” 20 October 1932: 8.

Lidové noviny. 1935. "Nový guvernér Podkarpatska," 23 February 1935: 5.

Lidové noviny. 1935. "Kniha moudrosti i lásky,” 27 May 1935: 5.

Lidové noviny. 1938. "Peníze za podpisy," 14 December 1938: 1.

Moravská orlice. 1934. "Podkarpatská Rus vykazuje ohromný pokrok,” 7 January 1934: 3.

Moravská orlice. 1934. "Problém karpatoruský a jeho vztah k republice Československé," 4 May 1934: 1.

Most mezi východem a západem. 1938. "Jak se informují historické země o Podkarpatské Rusi," March 1938: 20.

Národní listy. 1898. “Slavnost Palackého v Praze,” 19 June 1898: 3.

Národní listy. 1908. "Protest proti annexi Bosny a Hercegoviny," 16 October 1908: 1.

Národní listy. 1914. "Marmarošský proces,” 4 February 1914: 1.

Národní listy. 1914. "Po marmarošském procesu," 5 March 1914: 1.

Národní listy. 1919. "Karpatští Rusové v Praze,” 22 May 1919, Evening Edition: 1.

Národní listy. 1920. "Dva roky Podkarpatské Rusi,” 2 December 1920: 1.

Národní listy. 1921. "V Podkarpatske Rusi," 11 January 1921: 1.

Národní listy. 1921. "Sociální péče v Podkarpatské Rusi," 3 March 1921: 1.

Národní listy. 1921. "Dr. Žatkovič o své demisi,” 20 May 1921: 2.

Národní listy. 1921. "Zápas o Podkarpatskou Rus,” 21 May 1921: 2.

Národní listy. 1921. "Z Podkarpatské Rusi,” 22 June 1921: 1. 
Národní listy. 1925. "K Československému problemu,” 23 December 1925: 1.

Národní listy. 1927. “Kerenština ohrožuje naší Podkarpatskou Rus!” 6 April 1927: 1.

Národní listy. 1932. “Co chybí českému filmu?” 11 September 1932: 10.

Národní listy. 1933. "Povodeň se blíži," 14 July 1933: 4.

Národní listy. 1933. "Menšinová komise S.N. o Podkarpatské Rusi,” 31 December 1933: 5.

Národní listy. 1937. "V den autonomie Podkarpatské Rusi,” 3 Ocober 1937: 2.

Národní listy. 1938. "Parlament jedná o autonomii Slovenska a Podkarpatské Rusi," 19 November 1938: 1.

Národní listy večerník. 1932. “O Podkarpatské Rusi,” 23 March 1932: 1.

Národní politika. 1919. “General Hennoque ministru národní obrany k 1 máji,” 3 May 1919: 2.

Národní politika. 1919. “Jak jsou loveni krokodilové v Africké kolonii Togo,” 1 February 1919, Afternoon Edition: 1.

Národní politika. 1920. "Blahopřání gubernátora Dra Žatkoviče presidentovi republiky," 1 June 1920: 1.

Národní politika. 1920. "Hospodářský význam Podkarpatské Rusi,” 4 December 1920: 1.

Národní politika. 1922. "O poměrech v Podkarpatské Rusi,” 13 January 1922: 2.

Národní politika. 1927. "Bratr proti bratru,” 23 July 1927: 1.

Národní politika. 1928. "Nad čím by se měl zamysliti Anglický Lord Rothermere," 8 June 1928: $1-2$.

Národní politika. 1929. "Polské zájmy o Podkarpatskou Rus," 4 July 1929: 1.

Národní politika. 1932. “Podkarpatská Rus nejsou Čechy,” 14 April 1932: 3.

Národní politika. 1933. "Lidové umění,” 21 December 1933: 1.

Národní politika. 1936. "Několik poznámek pro letošního turistu,” 4 July 1936: 4.

Národnie noviny. 1927. "Pražský akt 22. Februára," 2 March 1927, 1.

Našinec. 1919. "Organisace autonomního zřízení v Přikarpatské Rusi,” 16 December 1919: 1-2. 
Našinec. 1921. "K otázce guvernerské na Podkarpatské Rusi,” 30 April 1921: 1.

Našinec. 1924. "Pražské zprávy,” 27 March 1924: 2.

Našinec. 1928. "Sensace Užhorodu a celé Podkarpatské Rusi,” 17 February 1928: 4.

Našinec. 1932. "Ivan Olbracht: Země bez jména," 1 June 1932: 4.

Našinec. 1935. "Poslanec kanovník Světlík o významu Podkarpatské Rusi,” 7 August 1935: 1.

Našinec. 1938. “Podkarpatská Rus se nedá zastrašít teroristy,” 27 October 1938: 1.

Našinec. 1938. “Andrey Brody zatčen,” 1 November 1938: 2.

Našinec. 1938. “Terroristická tlupa zneklidňuje Podkarpatskou Rus,” 20 November 1938: 3.

Nová doba. 1922. "Poměry v Podkarpatské Rusi," 13 January 1922: 2.

Nová doba. 1924. “Obrázky z Podkarpatské Rusi,” 9 March 1924: 1.

Nová doba. 1929. “Bahno na Podkarpatské Rusi,” 11 September 1929: 4.

Pestrý týden. 1927. “Umění na Podkarpatské Rusi,” 18 May 1927: 5.

Pestrý týden. 1935. “Podkarpatská Rus - Československý Orient,” 25 May 1935: 12.

Podkarpatská Rus. 1926. 9 January 1926: 2.

Podkarpatská Rus. 1926. "Pochopit pravou slovanskou politika," 30 January 1926: 2.

Podkarpatská Rus. 1926. "Podkarpatská Rus - Eldorado všech cizích dobrodruhů," 20 March 1926: 3.

Podkarpatská Rus. 1927. "Podkarpatoruský národ protestuje proti přeložení hlavního města a proti tomu, aby byl zkracován ve svých právech," 11 February 1927: 1.

Podkarpatská Rus. 1927. “Kde jsou mezi služební horlivosti?” 19 March 1927: 3-4.

Podkarpatská Rus. 1928. “Novoroční úvaha v r. 1928,” 5 January 1928: 1.

Podkarpatská Rus. 1928. 13 March 1928: 2.

Podkarpatská Rus. 1932. "Polský tisk o Podkarpatoruské autonomii,” 28 January 1932: 5.

Podkarpatské hlasy. 1925. "Náš směr," 3 January 1925: 1. 
Podkarpatské hlasy. 1925. "Naši největší neprátelé," 10 January 1925: 1.

Podkarpatské hlasy. 1925. “Čech na Podkarpatské Rusi - bez práv!” 17 January 1925: 2.

Podkarpatské hlasy. 1925. 17 January 1925: 3.

Podkarpatské hlasy. 1925. “Česká škola na Podkarpatské Rusi,” 7 February 1925: 1.

Podkarpatské hlasy. 1925. 21 March 1925: 3.

Podkarpatské hlasy. 1925. 28 March 1925: 3.

Podkarpatské hlasy. 1925. 21 April 1925: 3.

Podkarpatské hlasy. 1925. "Co se opravdu stalo!" 9 June 1925: 3.

Podkarpatské hlasy. 1926. "Daleko od Evropy," 4 February 1926: 2.

Podkarpatské hlasy. 1926. "Myšlenka slovanské vzájemnosti jak se na Podk. Rusi praktiku,” 23 February 1926: 3.

Podkarpatské hlasy. 1926. "P. Hlasy proti kyrilici a pravoslaví," 30 March 1926: 1.

Podkarpatské hlasy. 1926. 5 June 1926: 3.

Podkarpatské hlasy. 1928. "Na počátku byla tma...," 28 October 1928: 3.

Podkarpatské hlasy. 1936. “Ještě k otázce urbariální úpravy,” 25 February 1936: 2.

Polední list. 1937. “Podkarpatská Rus - budoucí naše kolonie,” 24 December 1937: 4.

Přitomnost. 1937. "Vizitez la Tchécoslovaquie!” 1 September 1937: 557.

Rozvoj. 1932. "Podkarpatská Rus," 8 April 1932: 4.

Slovenský východ. 1922. "Minister Tučný o svojej ceste na Podk. Rusi,” 30 May 1922: 1.

Slovenský východ. 1923. "Min predseda Švehla o Podkarpatskej Rusi,” 2 February 1923: 1.

Sokol. 1936. "Reportáže Ivana Olbrachta: Hory a staletí," August-September 1936: 212.

Štit. 1928. “Bojovníci proti 'Př́íšerné reakci',” 23 February 1928: 7.

Štít. 1933. "Dvůr Králové nad Labem," 4 May 1933: 3. 
Tribuna. 1920. "Systematisace úřednických míst v Rusínsku,” 22 October 1920: 2.

Večerní České slovo. 1934. "Marijka nevěrnice," 1 March 1934: 1.

Večerník národní listy. 1932. 23 March 1932: 1.

Věstník obecní hlavniho města Prahy. 1920. “Pomozte Podkarpatské Rusi!” 26 March 1920: 84.

Východočeský republikán. 1921. "Z Podkarpatské Rusi,” 5 August 1921: 2.

Zpravy Československého červeného křiže. 1923. “Senátor V. Klofáć,” 15 March 1923: 39.

\section{Czech-Language Books and Academic Publications}

Baum, Jiří. Africkou divočinou. Prague: L. Součka, 1933.

Bartl, Jaroslav. Podkarpatská Rus: Zeměpisný ilustrovaný přehled pro školu i soukromou potřebu. Velké Meziříčí: Aloise Šaška, 1932.

Beneš, Edvard. Edvard Beneš a Podkarpatská Rus. Uzhhorod: Klub T.G. Masaryka v Užhorodě, 2006.

Beneš, Edvard. "Podkarpatská Rus s hlediska zahraničně-politického.” Podkarpatská Rus, Jaroslav Zatloukal, ed., 17-19. Bratislava: Klub prátel Podkarpatské Rusi, 1936.

Beneš, Edvard. Podkarpatsko a jeho vztah $k$ Československu. Prague: Společnost přátel Podkarpatské Rusi, 1996.

Beneš, Edvard. Řeč o problému Podkarpatoruském. Prague: Orbis, 1934.

Beneš, Edvard. Úvahý o slovanství. Prague: Čin, 1947.

Bianchi, Gustav, ed. Publikace pro zem Podk. Rus. Banská Bystrica: Slovan, 1932.

Brandejs, Jan. "Vývoj politických poměrů na Podkarpatské Rusi v období 1918-1935." in Podkarpatská Rus, Jaroslav Zatloukal ed., 80-82. Bratislava: Klub přátel Podkarpatské Rusi, 1936.

Chalupný, Emanuel, and Dobroslav Krejčí, eds. Slovník národohospodárský sociální a politický. Prague: Otakar Janáček, 1933.

Dostál, Jaroslav. Podkarpatská Rus. Prague: Knižnice klubu československých turistů, 1936.

Doškár̆, Josef. Veřejné zdravotnictví v Podkarpatské Rusi. Uzhhorod: Ždímal a Vetešník, 1921.

Drahný, Václav, and František Drahný. Podkarpatská Rus: její př́rodní a zemědělské poměry. Prague: ministerstva zemědělství, 1921.

Durych, Jaroslav. Duše Podkarpatské Rusi. Prague: Přátel Podkarpatské Rusi, 1993. 
Dušek, Richard. Podkarpatská Rus jindy a nyní. Mukacheve: Karpatia, 1927.

Egán, Edmund. Hospodářský stav rusínských venkovanů v Uhrách. Prague: Rolnická tiskárna, 1922.

Hartl, Antonín. Podkarpatští Rusíni a my. Prague: A. Hartl, 1930.

Hatalak, Petr. Jak vznikla myšlenka připojiti Podkarpatskou Rus k Československu. Uzhhorod: Státní tiskárna, 1935.

Havlasa, Jan. České kolonie zámořské. Prague: Alois Wiesner, 1919.

Hlad v Podkarpatsku. Prague: Komitét dělnické pomoci pro zachránu hladovějícich v Podkarpatské Rusi, 1932.

Hodža, Milan. "U karpatských Rusov." in Články, reči, štúdie, vol. 3, 291-322. Prague: Novina, 1931.

Kadlec, Karel. Podkarpatská Rus. Prague: Nákladem Státovědecké Společnosti, 1920.

Káňa, Vašek. Zakarpatsko: Reportáž ze života ukrajinského proletariátu v Československu. Prague: Jaroslav Hoffmann, 1932.

Kasalický, Karel. Z Užhorodu pěšky na Hoverlu. Uzhhorod: Státní tiskárny, 1928.

Král, Jiří. Osídlení Podkarpatská Rus. Prague: Rajhrad, 1923.

Král, Jiří. Podkarpatská Rus. Prague: Unie, 1924.

Král, Jiří and Antonín Svoboda. Turistický průvodce Podkarpatskou Rusí a Slovenskem východné od Košic. Mukacheve: Novotný a Bartošek, 1923.

Křivanec, Karel. "Začátky referátu veřejných prací." in Vzpominky průkopníků technické služby v zemi Podkarpatoruské, 5-6. Uzhhorod: Státní tiskárny, 1933.

Krofta, Kamil. “Čechoslováci a Podkarpatská Rus.” in Podkarpatská Rus, Jaroslav Zatloukal, ed., 19-29. Bratislava: Klub Přátel Podkarpatské Rusi, 1936.

Krofta, Kamil. Podkarpatská Rus a Československo. Prague: Svaz národního osvobození, 1934.

Lev, Vojtěch. Brána na východ. Prague: Tiskový výbor Československé sociálně demokratické strany dělnické, 1920.

Liewald, Jan. "Z Mostaru do Užhorodu v roce 1920.” in Vzpomínky pri̊kopniků technické služby v zemi Podkarpatoruské. Uzhhorod: Státní tiskárny, 1933.

Linek, Josef. Podkarpatská Rus. Třebechovice pod Orebem: Josef Jarkovský, 1922.

Marie Majerová, Výlet do Československa. Prague: Melantrich, 1937. 
Masaryk, T.G. "Anexe a správa Bosny a Hercegoviny.” in Rakouská zahraniční politika a diplomacie Prague: Pokrok, 1911): 41-46.

Matoušek, Karel. Podkarpatská Rus. Prague: České grafické unie, 1924.

Musil, Jaromír, ed. Technická práce v zemi Podkarpatoruské 1919-1933. Uzhhorod: Státní tiskárny, 1933.

Nečas, Jaromír. Politická situace na Podkarpatské Rusi (rok 1921). Prague: Společnost přátel Podkarpatské Rusi, 1997.

Nečas, Jaromír. Prosím za jeden slovanský národ. Brno: Rolnické tiskárny, 1918.

Nečas, Jaromír. Uherská Rus a Česká žurnalistika: neuzavirejte kruh naších nepřátel. Uzhhorod: J. Skalák, 1919.

Nečas, Jaromír. Ukrajina v přerodu Ruska: Východoevropská tragedie a Ukrajina, její vývoj a životní síly. Prague: Všeslovanská Expedice B. Havlíček, 1919.

Nečas, Jaromír. "Začátky státní technické služby.” in Vzpomínky průkopníků technické služby v zemi Podkarpatoruské, 3-4. Uzhhorod: Státní tiskárny, 1933.

Nedzielskij, Jevgenij. “T. G. Masaryk v Karpatoruské písni.” in Podkarpatská Rus. Jaroslav Zatloukal. ed., 249-255. Bratislava: Klub př́tel Podkarpatské Rusi, 1936.

Nedzielskij, Jevgenij. T.G. Masaryk v Podkarpatoruském Basničtví. Bratislava: Podkarpatoruské nakladatelství, 1937.

Němec, Vilém. Má cesta do Afriky. Prague: Ant. Svěcený, 1916.

Neumann, Stanislav K. Československá cesta: část druhá a třetí. Prague: František Borový, 1935.

Neumann, Stanislav K. Enciány s Popa Ivana. Prague: František Borový, 1933.

Olbracht, Ivan. "Boj o kulturu na Podkarpatské Rusi." Literární noviny, September-November 1931, issue 16 (p.5), issue 18 (pp. 3-4), issue 19 (p.4), issue 20 (pp. 3-4).

Olbracht, Ivan, Vladislav Vančura and Karel Nový. Marijka nevěrnice. Czech National Film Archive, 1934.

Olbracht, Ivan. Nikola Šuhaj loupežnik. Prague: Artia, 1954.

Olbracht, Ivan. Země bez jména. Prague: Otto Girgal, 1932.

Pešek, Josef. Kulturni poměry a osvětová práce v P. Rusi. Prague: Orbis, 1921. 
Rosůlek, Jan Václav. Vưně Afriky. Pardubice: Vlastimil Vokolek, 1925.

Scheiner, Josef. "Sokolstvo," in Slovanstvo: Obraz jeho minulosti a prítomnosti. J. Polívka and J. Bidlo, eds. Prague: Jan Laichter, 1912.

Veselý, Antonín. “Užhorodské vzpomínky kolem r. 1920.” in Vzpomínky průkopníků technické služby v zemi Podkarpatoruské. Uzhhorod: Státní tiskárny, 1933: 16-21.

Zapletal, Florian. "Podkarpatská Rus částí Veliké Moravy?" Časopis vlasteneckého spolku musejního v Olomouci, 1926 edition.

Zatloukal, Jaroslav. "Za hlubším a objektivním poznáním Podkarpatské Rusi.” in Podkarpatská Rus. Bratislava: Klub přátel Podkarpatské Rusi, 1936.

Ženaty, Emil. Hospodářské základný Československé v Orientu. Prague: Masarykova Akademie Práce, 1931.

\section{Rusyn Newspapers with Author}

Brashchaiko, Mykhailo. "Bezposhchadna chekhizatsiia," Ukraïns'ke slovo, 27 June 1935: 1.

Brashchaiko, Mykhailo. "Pomer Toma Masaryk," Ukrä̈ns'ke slovo, 16 September 1937: 1.

Fentsik, Stefan. "Otkrŷtoe pys'mo Cheshskomu narodu," Nash put', 18 July 1935: 1.

Fentsik, Stefan. "Shestnadtsat' lît," Nash put', 10 September 1935: 1.

Mudry, P.H. “Kolonialna vystava," Sotatskii Russkii vîstnyk, 26 April 1936: 2.

Voloshyn, Avhustyn. Interview in Rusyn, 18 February 1923: 1.

\section{Rusyn Newspapers without Author}

Amerikansky russky viestnik. 1919. "Naš poklon - Ministru Beně̌,” 11 September 1919: 1.

Holos zhyttia. 1929. "Chekhizatsiia narodnoho shkil'nytstva na Zakarpatti," 15 October 1929: 3.

Holos zhyttia. 1930. "Ministr shkil'nytstva zaperechuie chekhizatsiiu Zakarpattia," 15 January 1930: 3 .

Holos zhyttia. 1933. "Verkhnyi zhandarm kazhe: 'mechte holodnykh ditei do tysy!" 18 June 1933: 2 .

Karpato-Russkii vîstnyk. 1921. "Protyv nashei samoupravŷ," 21 August 1921: 1. 
Karpato-Russkii vîstnyk. 1921. “Anomaliy,” 21 August 1921: 4.

Karpato-Russkii vîstnyk. 1923. "Cheshsky uchenŷ y nash iazŷk,” 21 January 1923: 4.

Karpato-Russkii vîstnyk. 1923. “Afrykansky poriadky,” 21 January 1923: 10-11.

Karpato-Russkii vîstnyk. 1923. "Nasha avtonomiia," 27 May 1923. 1.

Karpato-Russkii vîstnyk. 1923. "Peremîna," 6 December 1923: 1.

Nash put'. 1935. "Dr. S.A. Fentsyk y Ameryk. Rus'," 16 June 1935: 5.

Nash put'. 1935. "Píšte adres Latinským pismom," 5 November 1935: 3.

Novoje vremja. 1925. "Direktor Deržavnych Iisov Stripskij o industrializacii Podkarp. Rusi," 16 October 1925: 1.

Novoje vremja. 1927. "Protesty protiv akciji lorda Rothermere," 31 July 1927: 1.

Rusyn. 1923. "Mylŷi chytateliu!" 1 January 1923: 1.

Rusyn. 1923. "Kolonyzatsiia v Batiu,” 23 November 1923: 2.

Rus'ka nyva. 1921. "Hubernator Dr. Zhatkovych podiakovav," 24 March 1921: 1.

Rus'ka nyva. 1922. "Iak robliat' uriadnyky bratn'oho naroda," 9 November 1922: 2.

Rus'ka nyva. 1923. “Tsy ie u nas zemlî dlia chuzhykh kolonystov?” 11 October 1923: 1.

Rus'ka nyva. 1923. "D-r Petro Erenfeld," 29 November 1923: 1.

Rus'ka nyva. 1923. "Chekhy proty 'Prosvity’,” 20 December 1923: 2.

Russkaia zemlia. 1919. "Nashe prysoedynenie k Chekhoslovakiy,” 7 June 1919: 4.

Russkaia zemlia. 1919. “Avtonomiia Karpatskoi Rusy!” 21 August 1919: 1.

Russkaia zemlia. 1919. "Nasha avtonomiia," 18 October 1919: 2.

Russkaia zemlia. 1919. “'Prezydent' Zhatkovics Gergely,” 18 October 1919: 3.

Russkaia zemlia. 1919. “Avtonomnaia dyrektoriia,” 22 November 1919: 1.

Russkaia zemlia. 1919. "Svoboda y avtonomiia," 29 November 1919: 1.

Russkaia zemlia. 1919. "Mŷ trebuem,” 6 December 1919: 1. 
Russkaia zemlia. 1920. 19 June 1920: 2

Russkaia zemlia. 1921. “Avtonomiia nashei shkolŷ,” 14 April 1921: 2.

Russkaia zemlia. 1921. "V zashchytu nashei svobodŷ!” 24 November 1921: 1.

Russkaia zemlia. 1921. "Brat'iam Chekham,” 24 November 1921: 2.

Russkaia zemlia. 1922. 9 February 1922: 2.

Russkaia zemlia. 1922. "Vozmozhno-ly!” 11 May 1922: 1.

Russkaia zemlia. 1922. "Natsional'naia smert'," 17 August 1922: 1.

Russkaia zemlia. 1922. "Nasha shkola - ne nasha,” 25 August 1922: 1.

Russkaia zemlia. 1924. "Rezul'tatŷ vŷborov v Karpatskoi Rusy," 20 March 1924: 1.

Russkaia zemlia. 1924. "Chekhyzatsiia," 9 October 1924: 2.

Russkaia zemlia. 1924. "Vel. Bereznoe Cheshskaia shkola," 16 October 1924: 2.

Russkaia zemlia. 1925. "Kul'tura 'Podkarpatských hlasů' uzhe prynymaetsia," 12 February 1925: 1.

Russkaia zemlia. 1925. "Institut ohlupieniia ili Russkaia shkola?” 26 February 1925: 1.

Russkaia zemlia. 1925. "Masaryk polytyk y hosudarstvennŷi muzh," 5 March 1925: 1.

Russkaia zemlia. 1925. "Novaia hazeta," 25 June 1925: 2.

Russkaia zemlia. 1925. "Rezoliutsiia protyv ‘Podkarpatských hlasů’,” 2 July 1925: 1.

Russkaia zemlia. 1925. "Protest protyv hazetŷ 'Novoje Vremja'," 9 July 1925: 2.

Russkaia zemlia. "Shovynystŷ!” 15 October 1925: 1.

Russkaia zemlia. 1925. Campaign poster inserted in issue. 31 October 1925.

Russkaia zemlia. 1927. "Protest protyv sokrashcheniia nashei avtonomiy," 14 February 1927: 1.

Russkaia zemlia. 1927. "Edynŷi front," 23 February 1927: 1.

Russkaia zemlia. 1927. “Bosniaky y Russkii Ivan,” 17 March 1927: 1. 
Russkii vîstnyk. 1926. "Karpatskoi Rusy v Cheskom kanalî treba utopytysia...," 8 August 1926: 1.

Russkii vîstnyk. 1926. "Spasaite Karp. Rus' ot chekhyzatsiy," 8 September 1926: 2.

Russkii vîstnyk. 1927. "Yz Bosniatskykh 'hlas'-ov," 31 March 1927: 1.

Russkii vîstnyk. 1927. "Nashy Bosniaky," 7 April 1927: 3-4.

Russkii vîstnyk. 1927. "Chekha vsiudŷ, a Rusyna nykuda,” 28 April 1927: 3.

Russkii vîstnyk. 1928. "Frantyshek Svoishe arestovan,” 16 February 1928: 1.

Russkii vîstnyk. 1928. "8 Mai 1919 - 1928,” 10 May 1928: 1.

Russkii vîstnyk. 1935. “Agrarŷ obîshchaiut avtonomiiu,” 21 April 1935: 2.

Russkii vîstnyk. 1935. "Fentsykovcŷ - ne avtonomystî!” 8 May 1935: 1.

Russkii vîstnyk. 1935. "Fentsykovtsŷ protyv avtonomiy,” 14 May 1935: 6.

Russkii vîstnyk. 1938. "Podkarp. Rus' koloniia?” 9 January 1938: 2.

Russkii vîstnyk. 1938. "Vsî Karpatorossŷv odyn avtonomnŷi tabor,” 1 May 1938: 1.

Russkii vîstnyk. 1938. "Russkie liudy!” 8 May 1938: 1.

Russkii vîstnyk. 1938. "Koalychnyky durno opravdŷvaiut sebia,” 15 May 1938: 1.

Russkii vîstnyk. 1938. "Peremînŷ v Uriadakh," 23 October 1938: 3.

Russkii vîstnyk. 1938. "Rusynŷ!” 20 November 1938: 1.

Russkii vîstnyk. 1938. "Nemozhlyvoe polozhenie Podkarp. Rusy yz ohliadu relyhiinoho, natsional'noho y hospodarskoho," 11 December 1938: 1.

Sotatskii ruskii vîstnyk. 1938. "Podkarpatská Rus - budoucí naše kolonie," 16 January 1938: 1.

Svoboda. 1925. "Podkarpatské prase," 19 November 1925: 2.

Svoboda. 1927. “O Ches'kykh shkolakh,” 12 January 1927: 1.

Svoboda. 1927. "Narod Podkarpatskoî Rusy protestue protyv nasyl'stva," 11 February 1927: 1.

Svoboda. 1928. "Po Uzhhorodskym svyatŷ," 14 November 1928: 2. 
Svobodnoe slovo. 1925. 6 January 1925: 1.

Svobodnoe slovo. 1925. "Cheshskaia iumorystycheskaia hazeta 'Podkarpatske hlasŷ'," 19 February 1925: 2.

Svobodnoe slovo. 1925. "Uchytes po Cheshsky," 4 July 1925: 1.

Svobodnoe slovo. 1925. "Cheshskaia hazeta 'N. Vremeni' - Latynka protyv kyrylytsŷ," 22 August 1925: 1.

Ukraïns'ke slovo. 1935. "Dr. S. Fentsyk i Pol'ski hroshi presovyi spir Dra Fentsyka proty 'Ukraïns'koho slova',' 21 March 1935: 2.

Ukrä̈ns'ke slovo. 1935. "Politychna senzatsiia na Pidk. Rusy Dr. Stepan Fentsyk arestovanyi," 18 May 1935: 1.

Ukraïns'ke slovo. "Pro nas - do nas," 15 August 1935: 1.

Ukraïns'ke slovo. 1938. "Na vrodyny Masaryka," 9 March 1938: 1.

Ukraïns'ke slovo. 1938. “Avtonomiia dlia Slovachchyny,” 8 October 1938: 1.

Ukrä̈ns'ke slovo. 1938. "Pidkarpattia maie svoiu okremu vladu," 14 October 1938: 1.

Vpered. 1921. Unsigned letter to the editor from Rakhiv. 31 July 1921: 3.

Vpered. 1922. “Shche oden znatok Podkarpats'koî Rusy!” 22 January 1922: 2.

Vpered. 1922. "Reaktsiino-tsars'ki poriadky na Podkarpatskoi Rusy,” 23 July 1922: 2.

Vpered. 1922. "Dlia nashykh liudei nema mista v uriadakh,” 30 July 1922: 2.

Vpered. 1922. “Z Chekhamy, chy protyv Chekhov?” 13 August 1922: 2.

Vpered. 1922. “O nas, bez nas,” 13 October 1922: 4.

Vpered. 1922. "Shcho kazhe narod?” 13 October 1922: 4.

Vpered. 1923. "Kolonyzatsiia Podk. Rusy,” 19 October 1923: 1.

Vpered. 1924. “1924,” 11 January 1924: 1.

Vpered. 1924. "Iak uriady vystupaiut' proty nas,” 18 January 1924: 1.

Vpered. 1925. “T.G. Masaryk,” 7 March 1925: 1. 
Vpered. 1925. “'Podkarpat. Hlasy’ v sluzhbi krainoî Chekhyzatsîi Rusynov,” 22 August 1925: 2.

Vpered. 1932. "Holod na Pidkarpatti," 1 February 1932: 2.

Vpered. 1935. "Chekhyzatsiini plany," 1 March 1935: 3.

\section{Rusyn Books, Pamphlets and Academic Articles}

Brashchaiko, Mykhailo. Ches'ko-Rus'ki vzaemyny. Uzhhorod, Rusyn, 1923.

Brashchaiko, Mykhailo. T.G. Masaryk iak uchitel'. Uzhhorod: Vasiliian, 1930.

Dudykevych, Iosyf. Na marhinesi bidy Pidkarp. Rusy. Uzhhorod: Viktoriia, 1937: 3-4.

Hrendzha-Dons'kyi, Vasyl. Shchastia i hore Karpatskoi Ukrainy. Uzhhorod: Zakarpattia, 2002.

Ehrenfeld, Petr. "Iak rozvynuty Ches'ko-Rus'ku spivpratsiu," Iuvyleinyi al'manakh: Soiuzu Pidkarpats 'kykh Rus 'kykh Studentiv u Prazi 1921-1931, 29-30. Prague: 1931.

Prosvita. Leaflet "Manifest do Ukraïnskoho narodu Pidkarpattiia." 17 October 1937.

Nečas, Jaromír. Persha promova tov. posla ynzh. Ia. Nechasa v spravakh Podkarpat. Rusy. Uzhhorod: Sotsial-demokratichnoe partie Podkarp. Rusi, 1924.

Voloshyn, Avhustyn. Dvî polytychnî rozmovŷ. Uzhhorod: Rusyn, 1922.

Zhatkovych, Gregory. Expose Dr. G.I. Žatkoviča, byvšeho gubernatora podkarpatskoj rusi, o podkarpatskoj rusi. Homestead, Pennsylvania: Amerikansky russky viestnik, 1921.

\section{English-Language Books, Printed Media and Academic Articles}

American Rusin Council of National Defence. Memorandum to the League of Nations and Governments of Allied and Associated Powers as Signatories of the Peace Treaties of St. Germain en Laye. September 1928.

Baerlein, Henry. Over the Hills of Ruthenia. London: Leonard Parsons, 1923.

Beneš, Edvard. Bohemia's Case for Independence. London: George Allen and Unwin, 1917.

Bohemian Review. 1918. "Carpathian Russians and the Czechoslovaks." (May 1918, vol. 2, no. 5.): 70-72.

Bohemian Review. 1918. "The Great Czechoslovak Romance.” (August 1918, vol. 2, no. 8): 113117.

Čapek, Karel. Talks with T.G. Masaryk. North Haven, Connecticut: Catbird Press, 1995. 
Čapek, Karel. Three Novels: Hordubal, Meteor, An Ordinary Life. Highland Park, New Jersey: Catbird Press, 1990.

Danubian Review. 1938. "Struggle of Hungarians in Czecho-Slovakia." (May 1938, vol. 5, no. 12): 13-24.

Danubian Review. 1938. "The Ruthenians' Struggle for Autonomy." (August-September 1938, vol. 3, no. 4): 5-29.

Herczeg, Francis. “Triple Alliance?” in Danubian Review (February 1938, vol. 5, no. 9): 1-4.

Illes-Illyasevics, Joseph. "The Autonomy of Ruthenia and the Czecho-Slovak Minority Questions." in Danubian Review (July 1938, vol. 6, no. 2): 11-17.

Jászi, Oscar. "Dismembered Hungary and Peace in Central Europe." Foreign Affairs. 15 December 1923, 270-281.

Kollár, Ján. Reciprocity between the Various Tribes and Dialects of the Slavic Nation. Alexander Maxwell, trans. Bloomington, Indiana: Slavica, 2008.

Krofta, Kamil. Carpathian Ruthenia and the Czechoslovak Republic. London: Eyre and Spottiswoode, 1936.

Krofta, Kamil. The Substance of Hungarian Revisionism. Prague: Orbis, 1934.

Kutkafalvy, Miklós. Memorandum of the Ruthenians of Hungary to the Allied and Associated Powers and to all the Nations of the Cultured World, 1920.

London Times. "Riot in Ruthenia." 18 January 1939: 11.

London Times. 1939. "Capitulation by Ruthenia." 16 March 1939: 15.

Lukácz, György. "The Injustices of the Treaty of Trianon." in Justice for Hungary: Review and Criticism of the Effect of the Treaty of Trianon. Count Albert Apponyi, ed. London: Longmans, Green and Co., 1928.

Macartney, C.A. Hungary and her Successors: The Treaty of Trianon and Its Consequences. London: Humphrey Milford, 1937.

Masaryk, T.G. The Slavs among the Nations. London: The Czech National Alliance in Great Britain, 1916.

Mothersole, Jessie. Czechoslovakia: The Land of an Unconquerable Ideal. New York: Dodd, Mead and Co., 1926).

Papers and Documents Relating to the Foreign Relations of Hungary, volume 1, 1919-1920. Budapest: Royal Hungarian Ministry for Foreign Affairs, 1939.

Rothermere, Viscount. My Campaign for Hungary. London: Eyre and Spottiswoode, 1939. 
Rychlík, Jan, ed. R.W. Seton-Watson and his Relations with the Czechs and Slovaks, Documents 1906-1951. Banská Bystrica: Matica Slovenská, 1995.

R.W. Seton-Watson, "Czecho-Slovak Claims," in R.W. Seton-Watson and his Relations with the Czechs and Slovaks, Documents 1906-1951, Jan Rychlík et al., eds. (Banská Bystrica: Matica Slovenská, 1995), 292.

Seton-Watson, R.W. "The Situation in Slovakia and the Magyar Minority." Memorandum for President Masaryk, 1928. Reprinted in R.W. Seton-Watson and his Relations with the Czechs and Slovaks, Documents 1906-1951. Jan Rychlík et al. eds. Banská Bystrica: Matica Slovenská, 1995.

Suk, Vojtěch. "Anthropological and Medical Notes on the Peoples of the Subcarpathian Highlands." Man (May 1931, vol. 31), 90-91.

Udvardy, Nicholas. "Poland's Efforts to Obtain a Common Frontier with Hungary." Danubian Review (October-November 1938, vol. 6, no. 5-6): 15-19.

Wilson, Woodrow. "The Fourteen Points." Essential Writings and Speeches of the ScholarPresident. New York: NYU Press, 2006.

Winch, Michael. Republic for a Day: An Eye-Witness Account of the Carpatho-Ukraine Incident. London: Robert Hale, 1939.

Yuhasz, Michael. Wilson's Principles in Czechoslovak Practice: The Situation of the CarpathoRussian People under the Czech Yoke. Homestead, Pennsylvania: Amerikansky russky viestnik, 1929.

\section{Books and Media Publications in Other Languages}

Balkányi, L. Tiz év Podkarp. Ruszban. Uzhhorod: self-published, 1933.

“Beim Gouverneur Zatkovich,” Prager Tagblatt. 26 February 1921: 1.

Beneš, Edvard. Speech reprinted in Le Monde Slave. February 1934: 55.

Krofta, Kamil. Mémorandum du Gouvernement Tchécoslovaque: Territoire autonome des Ruthenes au sud des Carpathes. Prague: Czechoslovak Foreign Ministry, 15 September 1923.

Krofta, Kamil. La Tchécoslovaquie en face de la tension internationale. Prague: Orbis, 1937.

Ministry of Foreign Affairs of the Czechoslovak Republic. La Russie Subcarpathique au point de vue de la question des nationalités. Prague: Orbis, 1922.

Martel, Réné. La Ruthénie Subcarpathique. Paris: Hartmann, 1935. 
Ministry of Foreign Affairs of the Czechoslovak Republic. Mémoire concernent la Russie Subcarpathique: territoire ruthène du sud des Carpathes. Prague: Orbis, 1921.

Mousset, Jean. Les villes de la Russie Subcarpatique. Paris: Librairie Droz, 1938.

\section{Secondary Sources}

Adamová, Lenka. Ivan Olbracht. Prague: Horizont, 1977, 122.

Bakić-Hayden, Milica. "Nesting Orientalisms: The Case of Former Yugoslavia." Slavic Review (1995, 54/4): 917-931.

Batt, Judy. "Transcarpathia: The Centre of Europe." in Region, State and Identity in Central and Eastern Europe. Judy Batt and Kataryna Wolczuk, eds., 155-177. London: Routledge, 2013.

Bayly, Chris. Empire and Information: Intelligence Gathering and Social Communication in India 1780-1870. New York: Cambridge University Press, 1996.

Bayly, Chris. Imperial Meridian: The British Empire and the World, 1780-1830. London: Longman, 1985.

Bonkáló, Sándor. The Rusyns. New York: Columbia University Press, 1990.

Bradley, John Francis Nejes. The Czechoslovak Legion in Russia, 1914-1920. New York: Columbia University Press, 1991.

Bradley, John Francis Nejes. "Czech Pan-Slavism before the First World War." The Slavonic and East European Review (December 1961, vol. 40, no. 94): 184-205.

Budín, Viktor. Podkarpatská Rus očima Čechů. Prague: Společnost přátel Podkarpatské Rusi a Rusinká sekce, 1996.

Cervantes, Fred A. "Chicanos as a Postcolonial Minority: Some Questions Concerning the Adequacy of the Paradigm of Internal Colonialism." in Latina Thought. Francisco Hernández Vázquez and Rodolfo Torres, eds., 331-341. Lanham, Maryland: Rowman and Littlefield, 2003.

Cooper, Frederick. Colonialism in Question: Theory, Knowledge, History. Berkeley: University of California Press, 2005.

Donia, Robert J. Islam under the Double Eagle: The Muslims of Bosnia and Herzegovina 18781914. New York: Columbia University Press, 1981. 
Dyrud, Keith. The Quest for the Rusyn Soul: The Politics of Religion and Culture in Eastern Europe and in America, 1890 - World War One. Philadelphia: Balch Institute Press, 1992.

Fedinec, Csilla, and Mikola Vehes, eds. Kárpátalja 1919-2009, Történelem, politika, kultúra. Budapest: MTA Etnikai-nemzeti Kisebbségkutató Intézete, 2009.

Gates, E. Nathaniel. Introduction to: Racial Classification and History, E. Nathaniel Gates, ed., vii-xxii. New York: Garland Publishing, 1997.

Hannan, Kevin. Borders of Language and Identity in Teschen Silesia. New York: Peter Lang, 1996.

Healy, Róisín and Enrico Dal Lago. "Investigating colonialism within Europe." in The Shadow of Colonialism on Europe's Recent Past. Róisín Healy and Enrico Dal Lago, eds., 3-22. London: Palgrave Macmillan, 2014.

Hechter, Michael. Internal Colonialism: The Celtic Fringe in British National Development 1536-1966. Los Angeles: University of California, 1975.

Heimann, Mary. Czechoslovakia: The State that Failed. London: Yale University Press, 2009.

Heiss, Johann and Johannes Feichtinger. "Distant Neighbors: Uses of Orientalism in the LateNineteenth Century Austro-Hungarian Empire." in Deploying Orientalism in Culture and History: From Germany to Central and Eastern Europe, James Hodkinson and John Walker, eds., 148-165. Rochester, New York: Camden House, 2013.

Hermann, A.H. A History of the Czechs. London: Chaucer Press, 1975.

Hnízdo, Vlastislav. Ivan Olbracht. Prague: Melantrich, 1977.

Hobson, J.A. Imperialism: A Study. New York: J. Pott \& Company, 1902.

Hokky, Károly. Ruthenia: Spearhead towards the West. Trenton, Florida: Danubian Research Centre, 1966.

Holub, Miroslav. Introduction to: The Sorrowful Eyes of Hannah Karajich, by Ivan Olbracht, viixxii. Budapest: Central European University Press, 1999.

Holubec, Stanislav. "Czech Perceptions of Sub-Carpathian Rus and its Modernization in the 1920s." in Mastery and Lost Illusions: Space and Time in the Modernization of Eastern and Central Europe, Włodzimierz Borodziej, Stanislav Holubec and Joachim von Puttkamer, eds., 223-250. Munich: Oldenbourg, 2014.

Hořec, Jaromír. Podkarpatská Rus - země neznámá. Jinočany: H\&H, 1994. 
Howe, Stephen. Anticolonialism in British Politics: The Left and the End of Empire, 1918-1964. Oxford: Oxford University Press, 1993.

Jelinek, Yeshayahu. The Carpathian Diaspora: The Jews of Subcarpathian Rus and Mukachevo. New York: Columbia University Press, 2007.

Joly, Danièle. The French Communist Party and the Algerian War. New York: St. Martin's Press, 1991.

Judson, Pieter. Guardians of the Nation: Activists on the Language Frontiers of Imperial Austria. London: Harvard University Press, 2006.

Juhász, Gyula. Hungarian Foreign Policy, 1919-1945. Budapest: Akadémiai Kiadó, 1979.

Kann, Robert, and David Zdaněk. The Peoples of the Eastern Habsburg Lands, 1526-1918. Seattle: University of Washington Press, 1984.

Kemp, Tom. "The Marxist Theory of Imperialism." in Studies in the Theory of Imperialism, Roger Owen and Bob Sutcliffe, eds., 15-34. London: Longman Group, 1972.

King, Jeremy. Budweisers into Czechs and Germans. Princeton: Princeton University Press, 2002.

Kopp, Kristin. Germany's Wild East: Constructing Poland as Colonial Space. Ann Arbor: University of Michigan Press, 2012.

Kopp, Kristin. "Gray Zones: On the Inclusion of 'Poland' in the study of German Colonialism." in German Colonialism and National Identity. Michael Perraudin and Jurgen Zimmerer, eds., 33-42. New York: Routledge, 2010.

Lantová, Ludmila. Afterword to Hory a staletí by Ivan Olbracht., 240-261. Prague: Československý spisovatel, 1982.

Leff, Carol Skalnik. National Conflict in Czechoslovakia. Princeton: Princeton University Press, 1988.

Lemmen, Sarah. "Noncolonial Orientalism? Czech Travel Writing on Africa and Asia around 1918." in Deploying Orientalism in Culture and History: From Germany to Central and Eastern Europe. James Hodkinson and John Walker, eds., 209-227. Rochester, N.Y.: Camden House, 2013.

Lenin, Vladimir. Imperialism: The Highest Stage of Capitalism. Sydney: Resistance Books, 1999.

Lukes, Igor. Czechoslovakia between Stalin and Hitler: The Diplomacy of Edvard Beneš in the 1930s. New York: Oxford University Press, 1996. 
Magocsi, Paul Robert, and Ivan Pop, Encyclopedia of Rusyn History and Culture (Toronto: University of Toronto Press, 2002).

Magocsi, Paul Robert. "The Heritage of Autonomy in Carpathian Rus' and Ukraine's Transcarpathian Region,” Nationalities Papers (2015, vol. 43 no. 4): 577-594.

Magocsi, Paul Robert. A History of Ukraine: the Land and Its Peoples. Toronto: University of Toronto Press, 2010.

Magocsi, Paul Robert. "The Ruthenian Decision to Unite with Czechoslovakia." Slavic Review. (June 1975, vol. 34, no. 2): 360-381.

Magocsi, Paul Robert. The Shaping of a National Identity: Subcarpathian Rus, 1848-1948. London: Harvard University Press, 1978.

Magocsi, Paul Robert. With Their Backs to the Mountains: A History of Carpathian Rus' and Carpatho-Rusyns. Budapest: Central European University Press, 2015.

Mamatey, Viktor and Radomír Luža, eds. A History of the Czechoslovak Republic 1918-1948. Princeton: Princeton University Press, 1973.

Manela, Erez. The Wilsonian Moment: Self-Determination and the International Origins of Anticolonial Nationalism. New York: Oxford University Press, 2007.

Maxwell, Alexander. "Edvard Beneš and the Soft Sell: Czechoslovak Diplomacy towards Lusatia, 1918-1919.” Bohemia (vol. 46, 2014): 348-367.

Maxwell, Alexander. "Fickle Nationalism and Slovakia's Shifting Ethno-Linguistic Borders." in The Palgrave Handbook of Slavic Languages, Identities and Borders, Tomasz Kamusella, Motoki Nomachi, Catherine Gibson, eds., 230-244. London: Palgrave, 2015.

Maxwell, Anne. Colonial Photography and Exhibitions. London: Leicester University Press, 1999.

McClintock, Anne. Imperial Leather: Race, Gender and Sexuality in the Colonial Contest. New York: Routledge, 1995.

Meyer, Maria. The Rusyns of Hungary: Political and Social Developments 1860 - 1910. New York: Columbia University Press, 1997.

Mick, Christoph. "Colonialism in the Polish Eastern Borderlands 1919-1939." The Shadow of Colonialism on Europe's Recent Past. Róisín Healy and Enrico Dal Lago, eds. London: Palgrave Macmillan, 2014.

Nemec, František, and Vladimir Moudry. The Soviet Seizure of Subcarpathian Ruthenia. Toronto: William Anderson, 1955. 
Okey, Robin. Taming Balkan Nationalism: The Habsburg 'Civilizing Mission' in Bosnia 18781914. Oxford: Oxford University Press, 2007.

Orzoff, Andrea. Battle for the Castle: The Myth of Czechoslovakia in Europe, 1914-1948. Oxford: Oxford University Press, 2009.

Osterhammel, Jürgen. Colonialism: A Theoretical Overview. Princeton: Markus Wiener, 2005.

Perman, D. The Shaping of the Czechoslovak State: Diplomatic History of the Boundaries of Czechoslovakia, 1914-1920. Leiden, Netherlands: E.J. Brill, 1962.

Píša, A.M. Ivan Olbracht: Edice portréty spisovateli̊. Prague: Československý spisovatel, 1982.

Pop, Ivan. “Jak se vyvíjely názory Čechů na národní identitu Rusínů.” Podkarpatská Rus: časopis společnosti př́tel Podkarpatské Rusi. (January 2012): 8-9.

Pop, Ivan. Podkarpatská Rus. Prague: Libri, 2005.

Prasad, Pratima. Colonialism, Race, and the French Romantic Imagination. London: Routledge, 2009.

Pushkash, Andrei. Tsivilizatsiia ili varvarstvo, Zakarpate 1918-1945. Moscow: Evropa, 2006.

Qureshi, Sadiah. Peoples on Parade: Exhibitions, Empire and Anthropology in NineteenthCentury Britain. Chicago: University of Chicago Press, 2011.

Reynolds, Charles. Modes of Imperialism. Oxford: Martin Robertson, 1981.

Rivas, Paul Jeffrey. The White Pawn of Siberia: The Czechoslovak Legion in Russia 1914-1920. Milwaukee: University of Wisconsin, 1993.

Rupnik, Jacques. Dějiny komunistické strany Československa. Prague: Acedemia, 2002.

Rusinko, Elaine. Straddling Borders: Literature and Identity in Subcarpathian Rus'. Toronto: University of Toronto, 2003.

Rychlík, Jan and Vladimír Penčev. Dějiny Českých zemí (Prague: Vyšehrad, 2013).

Rychlík, Jan and Magdaléna Rychlíková. Hospodářský, sociální, kulturní a politický vývoj Podkarpatské Rusi 1919-1939. Prague: Národohospodářský ústav, 2013.

Said, Edward. Culture and Imperialism. New York: Vintage Books, 1993.

Said, Edward. Orientalism. New York: Vintage Books, 1978.

Schneider, Jane, ed. Italy's Southern Question: Orientalism in One Country. New York: Berg, 1998. 
Shandor, Vincent. Carpatho-Ukraine in the Twentieth Century. Cambridge, Mass.: Harvard University Press, 1997.

Spivak, Gayatri Chakravorty. "Empire, Union, Center, Satellite: The Place of Post-colonial Theory in Slavic/Central and East European / (post) Soviet studies: A Questionnaire." Ulbandus Review (2003, vol. 7): 5-25.

Štěpanek, Petr. Podkarpatská Rus v letech 1919-1939. Náchod: Konting, 2008.

Stercho, Peter George. Diplomacy of Double Morality: Europe's Crossroads in CarpathoUkraine. New York: Carpathian Research Centre, 1971.

Suda, Zdenek L. Zealots and Rebels: A History of the Communist Party of Czechoslovakia. Stanford: Stanford University, 1980.

Svoboda, David. “Češi v zemi beze jména.” Lidé města revue (March 2005, Volume 17): 117.

Švorc, Peter. "Začlenenie Podkarpatskej Rusi do ČSR (1918-1920).” in Česko-slovenská historická ročenka 1997, pp. 39-60. Brno: Masarykova univerzita, 1997.

Švorc, Peter. Zakletá zem: Podkarpatská Rus 1918 - 1946. Prague: NLN, 2007.

Taufer, Jiří. Stanislav Kostka Neumann: Básník, jeho doba a odkaz. Prague: Československý spisovatel, 1975.

Todorova, Maria. Imagining the Balkans. New York: Oxford University Press, 1997.

Vardy, Steven B. "The Impact of Trianon upon Hungary and the Hungarian Mind: The Nature of Interwar Hungarian Irredentism.” Hungarian Studies Review (Spring 1983, vol. 10, no. 1): $21-42$.

Vehesh, Mykola. Avhustyn Voloshyn i Karpats'ka Ukrä̈na. Lviv, ZUKTs, 2004.

Vyšný, Paul. Neo-Slavism and the Czechs 1898-1914. London: Cambridge University Press, 1977.

Wallace, William. Czechoslovakia. London: Ernest Benn, 1976.

Wingfield, Nancy Meriwether. Flag Wars and Stone Saints: How the Bohemian Lands Became Czech. Cambridge, Mass.: Harvard University Press, 2007.

Wolfe, Patrick. "History and Imperialism: A Century of Theory, from Marx to Postcolonialism." American Historical Review (April 1997): 388-420.

Wolff, Larry. Inventing Eastern Europe: The Map of Civilization on the Mind of the Enlightenment. Stanford: Stanford University Press, 1994.

Wolff, Larry. The Idea of Galicia: History and Fantasy in Habsburg Political Culture. Stanford: Stanford University Press, 2010. 
Young, Robert J. C. Postcolonialism: An Historical Introduction. London: Blackwell, 2001.

Young, Robert J. C. Postcolonialism: A Very Short Introduction. New York: Oxford University Press, 2003.

Zahra, Tara. "Imagined Non-communities: National Indifference as a Category of Analysis." Slavic Review (Spring 2010, no. 1): 93-119.

Zahra, Tara. Kidnapped Souls: National Indifference and the Battle for Children in the Bohemian Lands, 1900-1948. London: Cornell University Press, 2008.

Zeidler, Miklós. Ideas on Territorial Revision in Hungary 1920-1945. New York: Columbia University Press, 2007.

Zantop, Susanne. Colonial Fantasies: Conquest, Family and Nation in Precolonial Germany, 1770 - 1870. London: Duke University Press, 1997. 